UNIVERSIDADE DE SÃO PAULO

FACULDADE DE FILOSOFIA, LETRAS E CIÊNCIAS HUMANAS

DEPARTAMENTO DE LINGUÍSTICA

GUSTAVO ANDRÉ TÁRIBA BRITO

A construção semiótica do ator da enunciação nos memes verbovisuais de orientação política:

o estilo de um gênero midiático

Versão corrigida 
GUSTAVO ANDRÉ TÁRIBA BRITO

\section{A construção semiótica do ator da enunciação nos memes verbovisuais de orientação política: \\ o estilo de um gênero midiático}

Versão corrigida

Dissertação de Mestrado apresentada ao Programa de Pós-Graduação em Semiótica e Linguística do Departamento de Linguística da Universidade de São Paulo para obtenção do título de Mestre em Letras.

Orientadora: Norma Discini de Campos 
Autorizo a reprodução e divulgação total ou parcial deste trabalho, por qualquer meio convencional ou eletrônico, para fins de estudo e pesquisa, desde que citada a fonte.

Catalogação na Publicação

Serviço de Biblioteca e Documentação

Faculdade de Filosofia, Letras e Ciências Humanas da Universidade de São Paulo

Brito, Gustavo André Táriba

A construção semiótica do ator da enunciação nos memes verbovisuais de orientação polı́tica: o estilo de um gênero midiático / Gustavo André Táriba Brito ; orientadora Norma Discini de Campos. - São Paulo, 2020

$143 \mathrm{f}$.

Dissertação (Mestrado)- Faculdade de Filosofia, Letras e Ciências Humanas da Universidade de São

Paulo. Departamento de Linguística. Área de concentração: Semiótica e Lingüística Geral.

1. Semiótica. 2. Humor. 3. Memes de internet. 4. Estilo. I. de Campos, Norma Discini, orient. II. Título. 


\section{ENTREGA DO EXEMPLAR CORRIGIDO DA DISSERTACÃO/TESE Termo de Ciência e Concordância do (a) orientador (a)}

Nome do (a) aluno (a): Gustavo André Táriba Brito

Data da defesa: 29/05/2020

Nome do Prof. (a) orientador (a): Norma Discini de Campos

Nos termos da legislação vigente, declaro ESTAR CIENTE do conteúdo deste EXEMPLAR CORRIGIDO elaborado em atenção às sugestões dos membros da comissão Julgadora na sessão de defesa do trabalho, manifestando-me plenamente favorável ao seu encaminhamento e publicação no Portal Digital de Teses da USP.

São Paulo, 26/07/2020

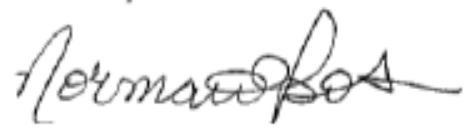

Profa. Dra. Norma Discini de Campos

Professora Associada, Aposentada, Permanente, do Programa de Pós-Graduação do Departamento de Linguística da FFLCH/USP 
Nome: BRITO, Gustavo André Táriba

Título: A construção semiótica do ator da enunciação nos memes verbovisuais de orientação política: o estilo de um gênero midiático

Dissertação de Mestrado apresentada ao Programa de PósGraduação em Semiótica e Linguística do Departamento de Linguística da Universidade de São Paulo para obtenção do título de mestre em Letras.

Orientadora: Norma Discini de Campos

Aprovado em: 29/05/2020

Banca Examinadora

Profa. Dra. Norma Discini de Campos - Universidade de São Paulo (USP)

Presidente

Profa. Dra. Maria Virgínia Leal - Universidade Federal de Pernambuco (UFPE) Membro externo

Profa. Dra. Eliane Soares de Lima - Universidade de São Paulo (USP) Membro interno

Profa. Dra. Mariana Luz Pessoa de Barros - Universidade Federal de São Carlos (UFSCar) Membro externo 
A Schneider e Vinha, pelas alegrias, pelo colo, pelo choro e apoio.

Incondicionais. 


\section{AGRADECIMENTOS}

Primeiro de tudo, minha imensa gratidão à professora Norma Discini, destinadora transcendental, cujos ensinamentos de todas as ordens foram para além das dimensões materiais desta dissertação. Grato pela grande parceria em todas as etapas da pesquisa.

A Virgínia Leal, que me trouxe à linguística. A Eliane Soares e Renata Mancini pelas contribuições trazidas no exame de qualificação e pelo carinho e preocupação ao longo deste percurso. Aos professores do Departamento de Linguística, em especial ao professor Ivã Lopes, que renova a minha vontade de alongar este curto caminho acadêmico por mim já trilhado.

À família do Grupo de Estudos Semióticos (GES-USP), pelos papos, palavras de afeto, suporte mútuo e pelas sempre necessárias cervejas. A Ana Noronha pela força redobrada na reta final da dissertação.

Aos membros do grupo "vip" do WhatsApp: Vinícius Lopes, Clarissa Monteiro, Leonardo Reitano, Marco Marinelli, Milton Guiguer, Hadassa Franca e Adriana Inácio pelo bom humor, companheirismo e troca de memes.

À família Aliança Francesa, Fabi, Naiara, Bia, Cleiton, Cindy e Caroline. Esta dissertação, sem vocês, não seria possível.

À minha própria família, Mainha, Marquinhos e Fábio. E peço desculpas à minha irmã, Sofia, pelo mal humor de cão raivoso desses dois últimos anos.

A João, Sarah, Ney e Louise que me acolheram aqui em São Paulo e não têm ideia da falta que fazem desde que decidiram voltar à terrinha. A Eduardo e Júlia por ainda estarmos juntos nessa vida depois de tanto tempo, sempre do mesmo lado das trincheiras.

Ao coletivo da rede Instagram \#saquinhodelixo e a todos os envolvidos.

Obrigado ao CNPq pelo apoio à nossa pesquisa em época tão incerta. 


\section{RESUMO}

BRITO, G. A. T. A construção semiótica do ator da enunciação nos memes verbovisuais de orientação política: o estilo de um gênero midiático. 2020. Dissertação (Mestrado) Faculdade de Filosofia, Letras e Ciências Humanas, Universidade de São Paulo, São Paulo, 2020.

Esta dissertação se propôs a estudar o ator da enunciação dos memes políticos humorísticos, visto como éthos e como um estilo a ser depreendido das redes sociais, um ator apresentado nos próprios enunciados meméticos mediante um papel actancial (destinador de valores) e um papel temático que diz respeito ao tratamento axiológico e ideológico conferido aos temas e às figuras do discurso. Ao considerar o autor dos memes um ator da enunciação, que, para exercer tal função, desempenha os papéis referidos, problematizamos o criador desse novo gênero discursivo, próprio à comunicação online, não como pessoa de "carne e osso", isto é, um sujeito biografado, mas um efeito de sentido de identidade, que constrói um estilo próprio (DISCINI, 2015) para subverter o noticiário midiático, fazendo o leitor rir dos fatos do mundo noticioso. Logo, longe de tangenciarmos o ator militante de uma bandeira partidária, buscamos o ator cuja voz é delegada a um narrador, conforme a sintaxe discursiva (FIORIN, 2016a) - no esquema de delegação de vozes subjacente a esses enunciados online que são os memes. Investigamos, portanto, esse ator, que é percebido nas redes de relacionamento social não apenas como alguém que produz humor, mas que é igualmente crítico e moralizante.

Palavras-chave: Semiótica. Humor. Memes de Internet. Estilo. 


\begin{abstract}
BRITO, G.A.T. The semiotic construction of the enunciation actor in politically oriented verb-visual memes: the style of a media genre. 2020. Dissertação (Mestrado) - Faculdade de Filosofia, Letras e Ciências Humanas, Universidade de São Paulo, São Paulo, 2020.

The aim of this thesis is to study the enunciation actor in humorous political memes, seen as ethos and as a style from social networks. An actor presented in the memetic enunciate through an actantial role (value addresser) and a thematic role related to the axiological and ideological approach given to the themes and figures of discourse. When considering the author of a meme an enunciation actor (who, in order to be considered so, plays the aforementioned roles), we problematize the creator of this new genre of discourse, typical of online communication, not as a "flesh and bone" individual, that is, a biographical subject, but as an effect of meaning that builds its own style (DISCINI, 2015) to subvert the news, making the reader laugh at events reported in the media. Thus, instead of focusing on militants of political parties, we turn our attention to the actor whose voice is delegated to a narrator, according to discourse syntax (FIORIN, 2016a) - in the voice delegation scheme underlying these online enunciate known as memes. Therefore, we investigate that actor, perceived in social networks as someone who not only produces humor but is also critical and moralizing.
\end{abstract}

Keywords: Internet Memes. Semiotics. Humor. Style. 


\section{LISTA DE ILUSTRAÇÕES}

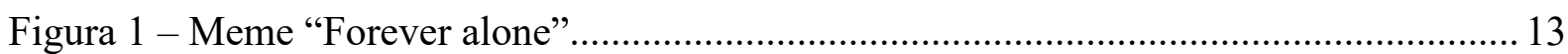

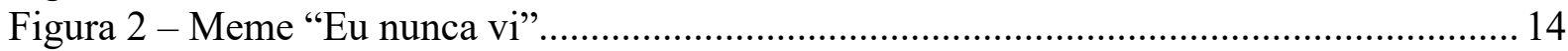

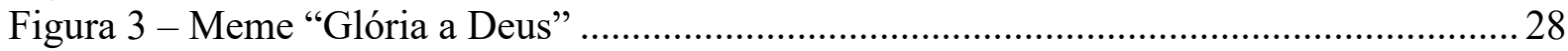

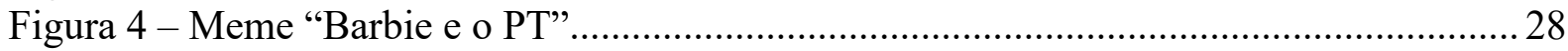

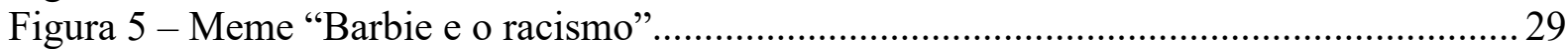

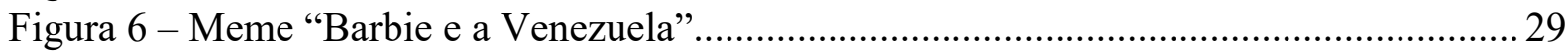

Figura 7 - Quadrado Semiótico Semelhança x Diferença .................................................... 38

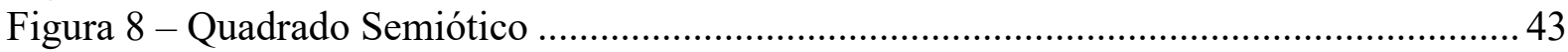

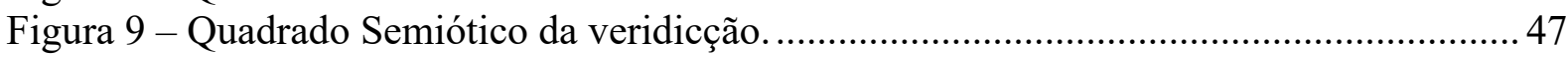

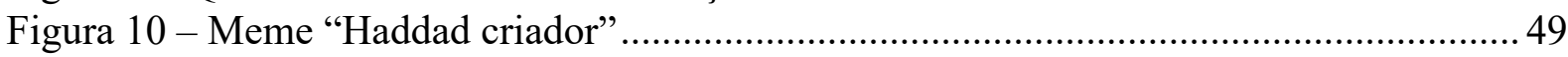

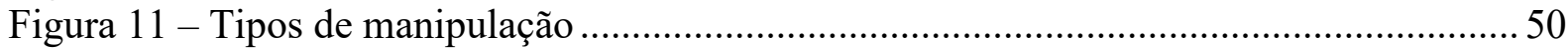

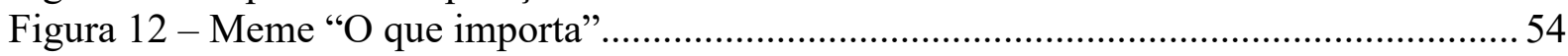

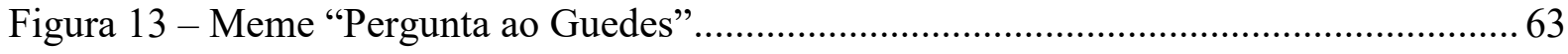

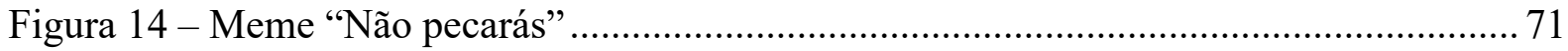

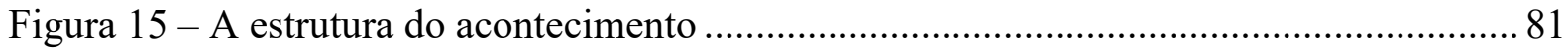

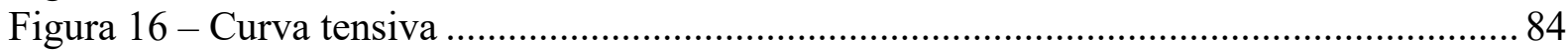

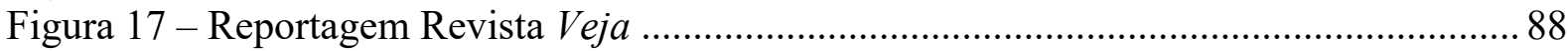

Figura 18 - Temas e Figuras da reportagem "Bela, recatada e do lar" .................................. 94

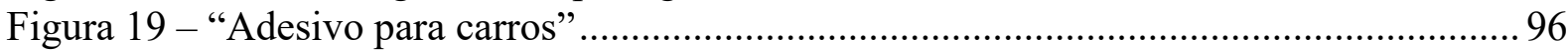

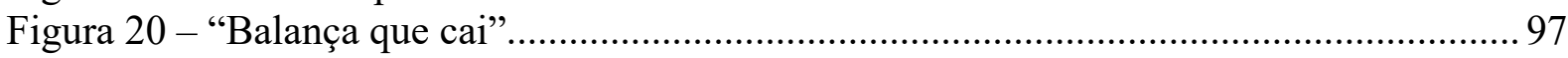

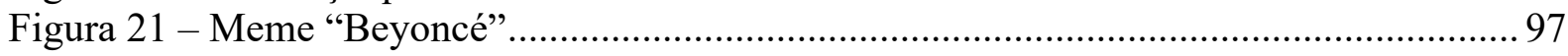

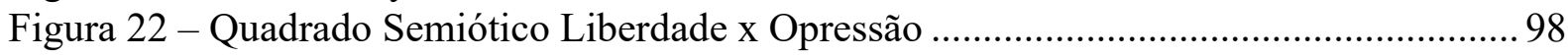

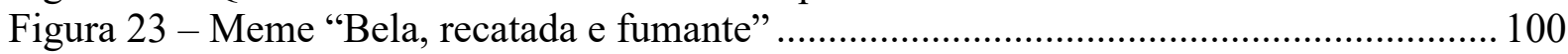

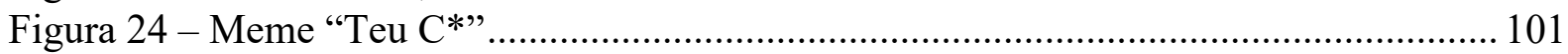

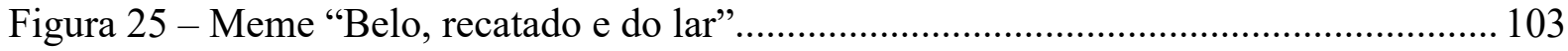

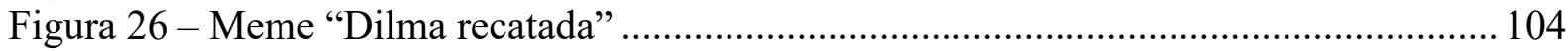

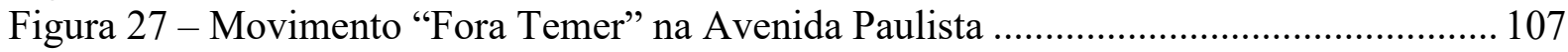

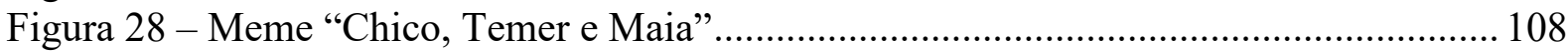

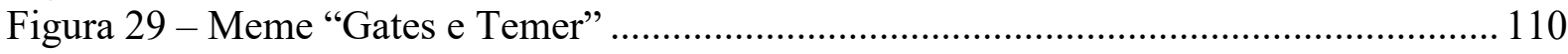

Figura 30 - Quadrado Semiótico Identidade x Alteridade................................................ 115

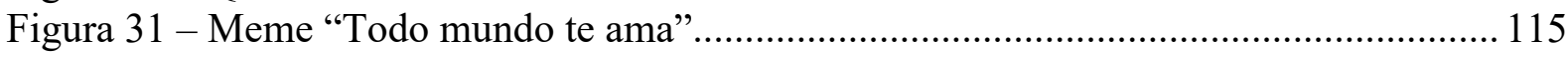

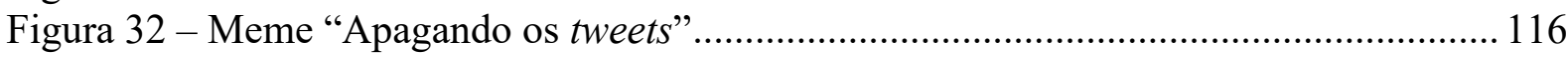

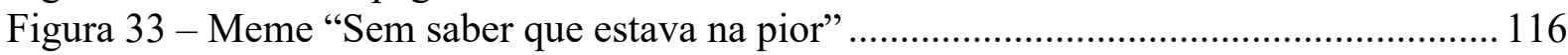

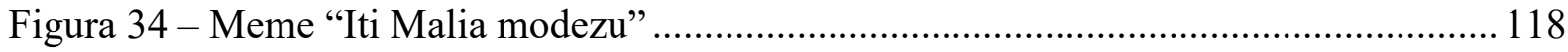

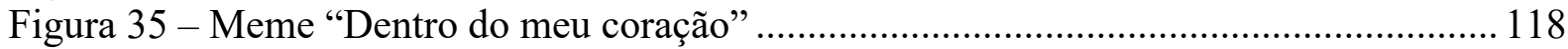




\section{SUMÁRIO}

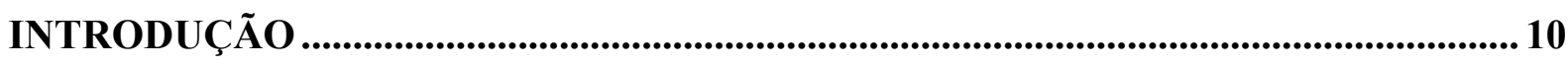

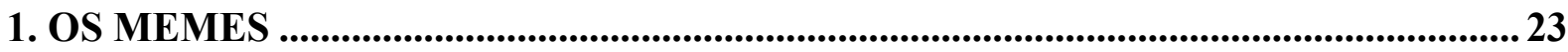

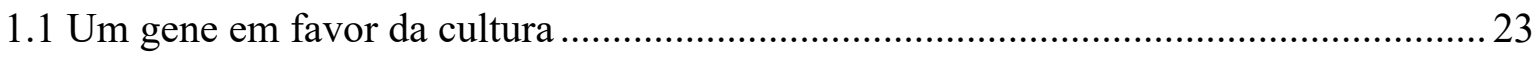

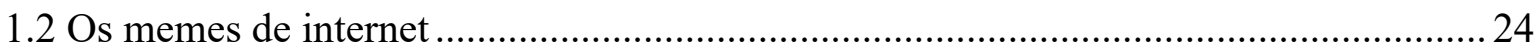

1.3 Os memes da política e a política dos memes .............................................................. 26

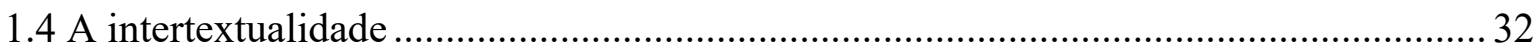

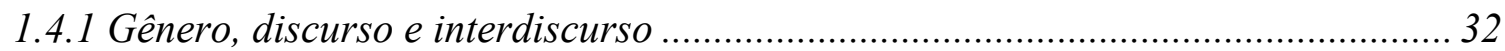

1.4.2 A propagação na memesfera: replicação, invenção, imitação e recriação.............. 36

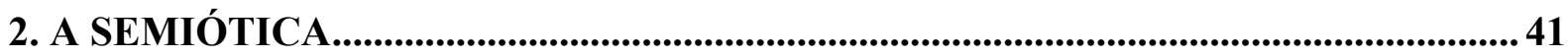

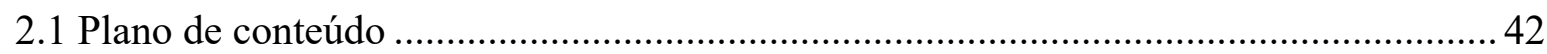

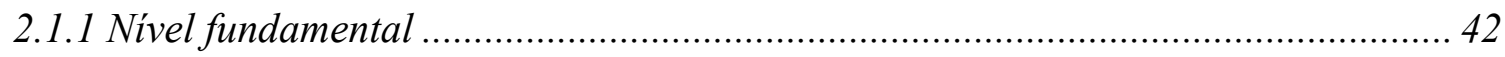

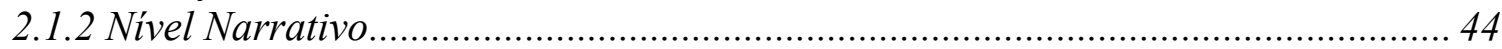

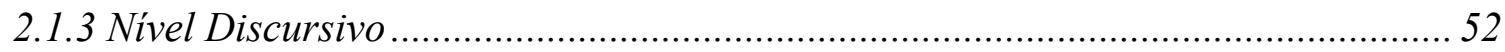

2.2 Plano de expressão - A enunciação sincrética …………………………………….......59

3. HUMOR E TENSIVIDADE NOS MEMES DE POLÍTICA..........................................63

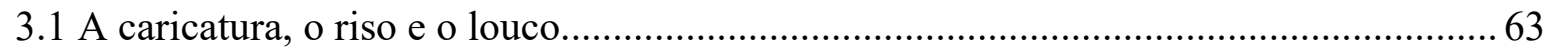

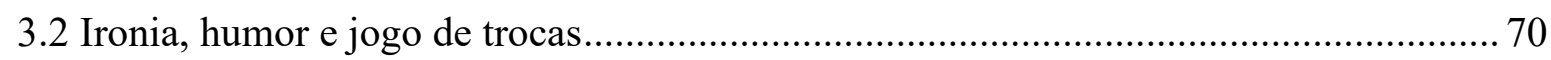

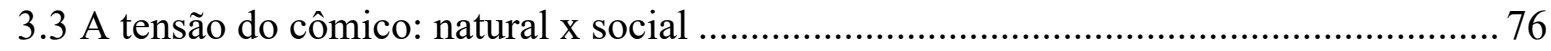

3.4 Entre o acontecimento noticioso e o exercício através do cômico.................................... 80

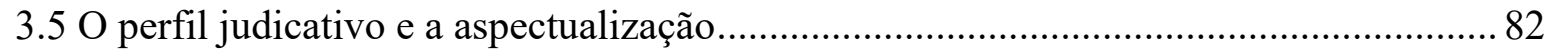

4. DEPREENSÕES TEÓRICO-ANALÍTICAS ................................................................. 86

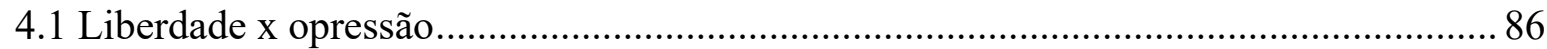

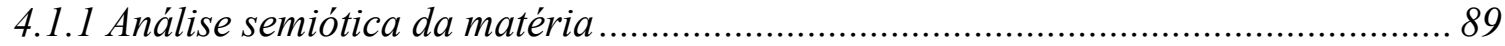

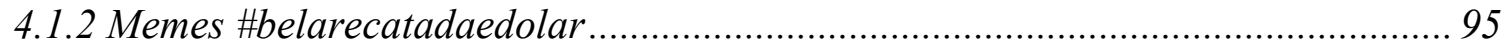

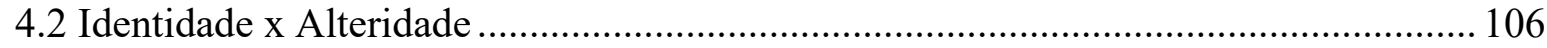

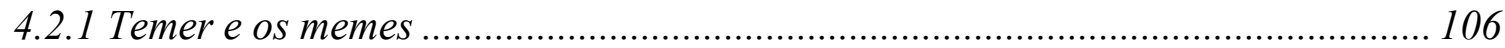

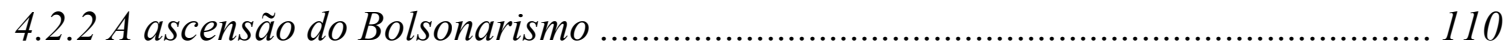

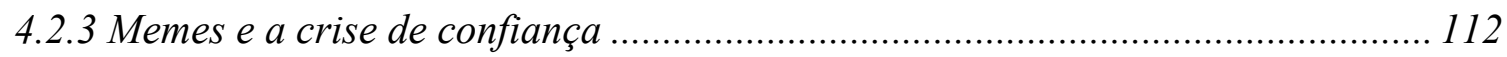

5. CONSIDERAÇÕES FINAIS ....................................................................................... 124

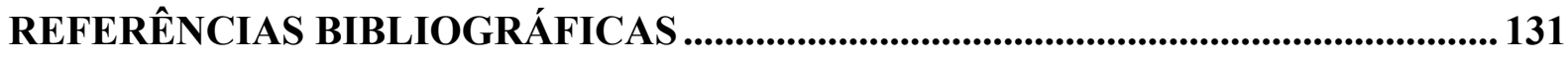

LISTA DE REFERÊNCIA DE SITES DE NOTÍCIAS E VÍDEOS...................................136

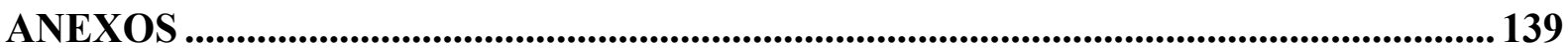




\section{INTRODUÇÃO}

O nome "fenômeno da internet" parece ser uma alcunha aceita de maneira unânime na tentativa de achar uma melhor definição para o que seria um meme, uma vez que a acepção dicionarizada do termo ainda não existe. Logo, como em todo dito "fenômeno", o ineditismo do nosso objeto de trabalho requer uma laboriosa atenção metodológica e epistemológica desses enunciados sincréticos e verbovisuais, os quais parecem não possuir registro acadêmico de quando surgiram no Brasil, de quais seriam os seus primeiros exemplares e muito menos sobre o porquê de eles serem um sucesso entre os usuários da web. Como um vírus altamente contaminável, eles estão "postos no mundo" e por isso merecem, digamos, uma certa dose de curiosidade científica acerca do assunto. Sabemos de maneira bastante intuitiva que aquelas imagens humorísticas geralmente dizem algo para alguém. Elas conversam com um público específico que se individualiza como o leitor dos memes, leitor este que tem em mente a imagem daquele que se identifica com aquele conteúdo humorístico e crítico veiculado discursivamente.

Este trabalho sobre a construção semiótica do humor na internet por meio do gênero meme teve seu pontapé inicial no ido ano de 2007. Nesse ano eu era ainda aluno da graduação de Letras na Universidade Federal de Pernambuco, UFPE. Sob a tutela da professora Virgínia Leal, realizamos um projeto de estudo pelo Programa Institucional de Bolsas de Iniciação Científica (PIBIC), com o apoio de bolsa de fomento do CNPq, intitulado Epitáfios humorísticos: uma análise das ambiguidades como estratégia discursiva constitutiva do gênero, durante o qual procuramos verificar de que modo as ambiguidades constroem as imagens de "si" e de "outrem" a partir da análise de epitáfios fabricados para a produção e circulação de humor na internet.

Em todos os epitáfios humorísticos que vimos havia uma imagem-base de um túmulo qualquer que se repetia, porém a mensagem verbal mudava de acordo com a profissão formal do sujeito. No epitáfio do humorista constava "isso não é engraçado". No do bêbado, "enfim sóbrio". No do comentarista esportivo da TV Globo, "enfim mudo". As identidades desses sujeitos eram construídas, satirizadas e subvertidas pelo humor através desses textos. O efeito de humor emergia da ambiguidade entre o papel social assumido por cada um e a fina ironia de como eles eram descritos em suas últimas palavras. 
$\mathrm{Na}$ época, vários sites de entretenimento e blogs divulgavam a piada online. Por e-mail, as pessoas a repassavam sem fazer nela nenhuma modificação. As ferramentas de tratamento de imagens digitais não eram de tão fácil manuseio como as de hoje, o que justifica o fato de que o engajamento dos usuários com o discurso se restringia a uma simples replicação.

Depois de recebido o diploma de Bacharel em Língua Francesa, em 2011, por mais que o objeto causasse em mim a ideia de levá-lo adiante, pois julgo que o humor merece seu devido lugar nos estudos científicos, a vida foi tomando outros rumos, adiando por algumas vezes esse sonho de ser mestre.

Se naquele tempo do PIBIC os meios de divulgação e produção de conteúdo online fossem mais avançados e se já conhecêssemos esse tipo de gênero textual da internet, não titubearíamos em apontar o olhar discursivo e semiótico para os textos humorísticos dos epitáfios e dizer que, na verdade, eles tratavam de esboços do que mais tarde se consagraria como memes de internet.

Os memes têm uma particularidade que descobrimos logo ao adentrarmos o estudo semiótico desse nosso objeto: eles não são uma única imagem que chega a um número grande de compartilhamentos, senão não teriam recebido a alcunha de memes. Esse novo gênero de discurso nunca vem desacompanhado de uma sequência, uma vez que memes são sempre em série. Uma imagem reconhecível de um personagem como o do ator de Hollywood John Travolta no filme Pulp Fiction, em que o astro fica olhando pelos cantos, perdido, sem saber para onde ir, não é por si só um meme. No entanto, no momento em que um fundo diferente é adicionado a tal imagem, já podemos dizer que esse é um texto memético. Portanto, é condição sine qua non para o meme é a existência de outro texto do qual é derivado.

Yvana Fechine (2018), professora e semioticista da Universidade Federal de Pernambuco, afirma que um meme só existe na presença de outro meme. Ou seja, só a partir da primeira confecção memética outras tantas surgirão. $O$ site da internet KnowYourMeme $e^{1}$ pode fornecer essa informação a respeito de vários memes que se popularizaram nos últimos anos. Contudo, o site reside nos Estados Unidos e é feito para o público americano, apesar de ter alguns exemplares de memes com o selo Made in

\footnotetext{
1 KnowYourMeme é um site dedicado a categorizar os memes de internet informando o ano de aparecimento, quantos compartilhamentos teve, os tipos de memes (imagem macro, micro, fotolegenda) e os organiza por tema, personagens e afins. Disponível em: www.knowyourmeme.com. Acesso em $04 \mathrm{de}$ abril de 2020.
} 
Brazil. Com a falta da informação sobre o surgimento da cadeia memética, resta-nos apenas observar o grau de variações textuais e discursivas entre um meme e outro do mesmo sintagma.

Com esse conhecimento, é possível identificar que os epitáfios do nosso estudo do PIBIC eram exemplares das primeiras "manifestações meméticas" (CHAGAS, 2018) a acontecer posteriormente nas redes sociais. Aquela ideia de retornar à universidade como estudante de ensino superior ganhava cada vez mais corpo, atraído por estudar um objeto tão novo e tão usado pelos internautas, os memes.

Para esta dissertação, de início me propus a analisar unicamente os memes relativos à figura de Michel Temer no papel de presidente do Brasil. Quando fiz o projeto para o ingresso ao programa de pós-graduação em linguística na Universidade de São Paulo (USP), o ex-presidente havia baixado uma lei que punia aqueles que utilizassem imagens oficiais do governo para produção de memes. Mas nisso havia um porém: quem são esses tais produtores de meme (memistas ou memeiros) que produzem imagens engraçadas das figuras políticas, já que nos discursos eletrônicos é permitido o anonimato? E por que essa brincadeira da chamada subcultura da internet chegou um dia a incomodar o presidente a ponto de ele querer censurá-la? Talvez calhe aqui dizer: uma imagem vale mais que mil palavras, o que para bom entendedor é mais que o suficiente. Poderíamos nos aventurar numa hipótese de que o forte apelo visual dos memes se justificaria como preocupação do ator político em pauta.

Sendo assim, é importante observar os memes que, construídos mediante a reunião do verbal e o visual, compõem um universo próprio de crenças e aspirações. Ao postar um meme nas redes, o enunciador expressa de maneira aparentemente simplificada ideias complexas que levariam talvez à prolixidade de algumas frases. Desse modo, enunciador e enunciatário partilham do código memético para "decifrar" o que a junção do verbal + visual significa em seu todo. Em vez de dizer "estou muito triste", ele pode colocar o meme do "forever alone" (Figura 1) (SHIFMAN, 2014, p. 173), que condensa todo o sentimento numa enunciação, digamos, econômica. 


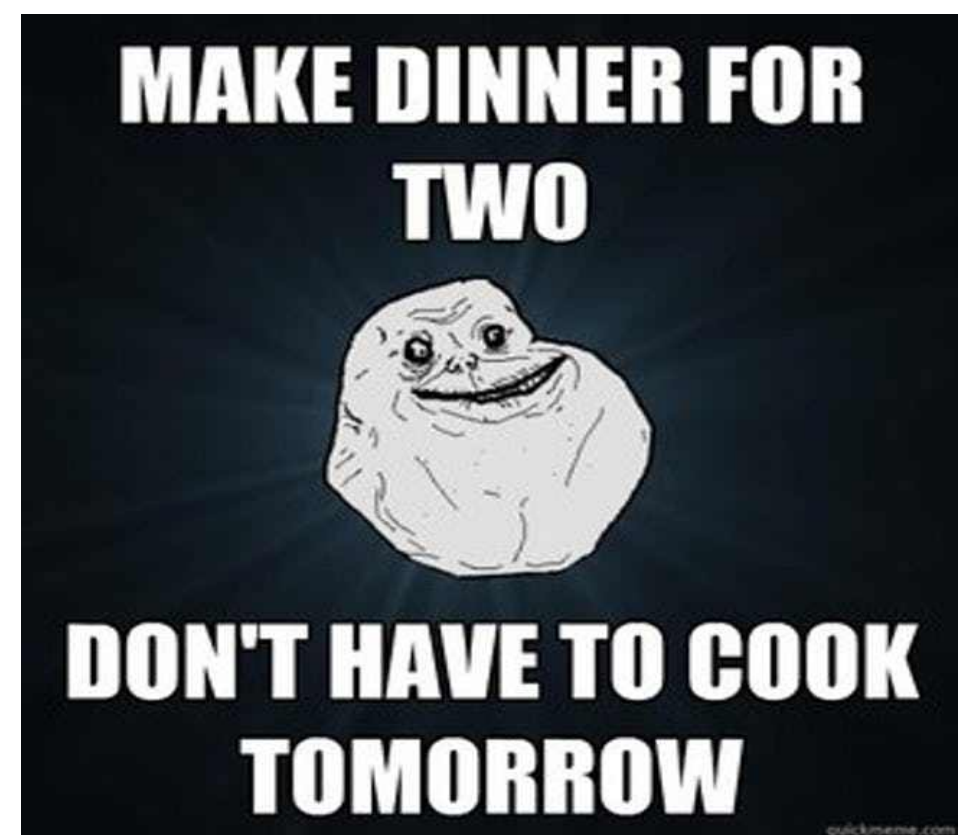

Fonte: https://imgix.ranker.com/user_node img/50008/1000154225/original/forever-alone-on-cookingphoto-u1 $\mathrm{w}=650 \& \mathrm{q}=50 \& \mathrm{fm}=$ pjpg\&fit=crop\&crop=faces. Acesso em 09 de dezembro de 2019.

Ao afirmar seu status de "para sempre sozinho", o enunciador "vende" uma imagem de "si" para o enunciatário que o faz crer no seu estado de solidão. A noção de estar sozinho se concentra na figura visual, que contraria o "Two", o qual suporia o "eu" e o "outro". A figura acima é uma charge ilustrativa que nos serve de exemplo para entendermos melhor a linguagem condensada que aparecerá nos memes.

No meme político não é diferente. Se um sujeito anda insatisfeito com o governo ou com a liderança política da sua cidade, estado, país (ou até o país dos outros), faz sua queixa por um meme nas timelines ${ }^{2}$ do Facebook ou do Twitter, evitando uma longa postagem de protesto.

\footnotetext{
${ }^{2}$ De acordo com o dicionário Cambridge Dictionary, timeline, ou linha do tempo, remete a uma função das redes sociais na qual são mostrados itens que foram adicionados pelo próprio usuário dono da conta ou pelos contatos que ele tem nessa mesma rede.
} 


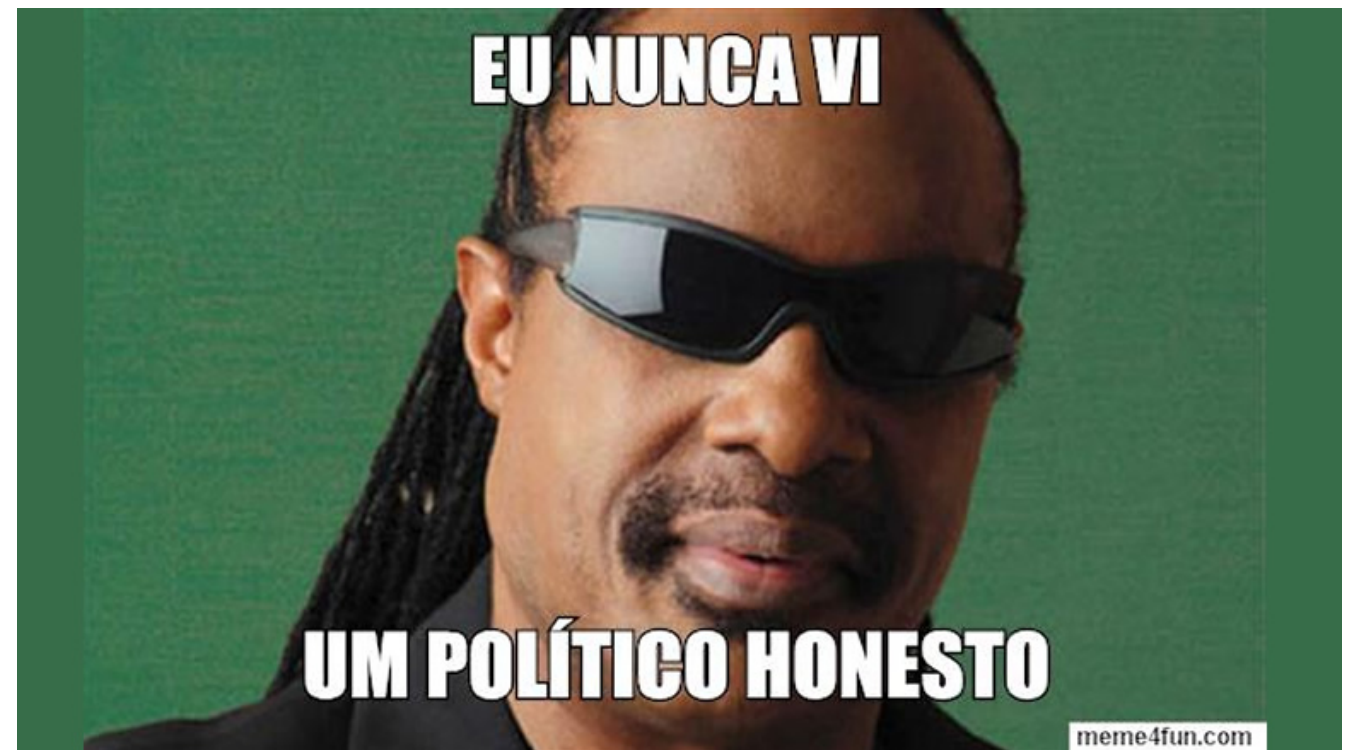

Fonte: https://papodeeducador.com.br/wp-content/uploads/2018/06/meme.jpg. Acesso em 09 de dezembro de 2019.

Ao olharmos semioticamente para o segmento visual, temos implícito um narrador, voz delegada pelo enunciador, figurativizado no olhar frontal do ator do enunciado para o leitor. Aí está o princípio de que o meme faz crer que aquilo que é dito esteja no domínio da verdade tal qual é entendida pelo contrato de veridicção proposto por Greimas (GREIMAS; COURTÉS, 2012). O sujeito que narra delega voz ao ator do enunciado (o personagem), figurativizado pelo cantor Stevie Wonder (Figura 2). Logo, temos um ator que traz consigo determinado preenchimento semântico, efetuado pelo papel que evoca sua prática de ser cantor e sua deficiência visual. Esse recurso dá ao enunciado maior efeito de sentido de verdade do mundo narrado. O humor está presente na ambiguidade verbovisual, que se constrói entre a conhecida cegueira do cantor e a frase verbal "eu nunca vi". Implicitamente, o enunciador do meme defende o ponto de vista de que não existe político honesto, seja na percepção de um cego, seja na percepção de quem enxerga direito.

Antes de prosseguirmos, é importante fazer uma distinção entre autor e ator da enunciação. O primeiro, como diz Fiorin (2016a), ao lembrar o escritor da literatura brasileira, é Machado de Assis de carne e osso, sujeito biografado. Já o ator da enunciação é efeito de identidade construído pelo discurso, ou melhor, pela totalidade discursiva, que significa o todo da obra machadiana, que apresenta um modo recorrente de dizer, como, por exemplo, o emprego contínuo da ironia. 
Nos memes, interessa o ator da enunciação: o sujeito da enunciação. Acontece que a enunciação aparece nos memes não apenas sob a voz do narrador, necessariamente implícito e vez ou outra explícito, como também uma enunciação de segundo grau. No caso do último meme (Figura 2), o interlocutor, o ator do enunciado, é uma enunciação de segundo grau. É um discurso direto, que aparece sob os efeitos da linguagem verbal e visual unidas. $\mathrm{O}$ "eu” da enunciação, o autor implícito ao meme, não é mais do que uma posição sintática admitida na actorialização do sujeito actancial.

Memes, como afirmamos, são normalmente anônimos. Isso significa que não há um "eu" assumido mediante uma assinatura. Qualquer um pode tê-los feito. E particularmente, para a brincadeira das trocas meméticas, isso importa muito pouco. $\mathrm{O}$ enunciador, que, fora do texto, pode ser o autor ou pode ter pego o meme de algum lugar virtual, fabrica uma imagem de "si" para o seu enunciatário. Na memesfera o maior valor em jogo é o efeito de identidade construído pelo modo de dizer.

Não apenas pelo conteúdo que vincula, mas pelo modo de enunciar, chegamos à imagem do enunciador dos memes como recurso que compõe o ator da enunciação memética. O enunciatário, por sua vez, ao reconstruir o sentido discursivizado, firma-se também como coprodutor do sentido do meme, o que se deve ler nas entrelinhas da manifestação verbovisual.

A imagem de "si" diz respeito ao éthos, sendo tal imagem construída pelo auditório, tal qual prevê Aristóteles na sua Retórica (1979). Para Maingueneau (2013), o éthos é composto por um tom, por um corpo e por um caráter produzidos por estratégias enunciativas no interior do texto e não fora dele.

Para a Semiótica Discursiva, “fora do texto não há salvação”, como dizia Greimas. Matheus Schwartzmann (2018), explicando a concepção teórica de semiótica de Fiorin, afirma que para o semioticista, embora a semiótica francesa não ignore que o texto seja um objeto histórico, ela "[...] dá ênfase ao conceito de texto como objeto de significação e, por conseguinte, preocupa-se fundamentalmente em estudar os mecanismos que engendram o texto, que o constituem como uma totalidade de sentido" (FIORIN, 1995, p. 166).

Entre os mecanismos que engendram o texto, está o nível discursivo do percurso gerativo do sentido, no qual são instituídos o enunciador e o enunciatário e, dentre eles, há valores a serem partilhados. Temos então, a partir daí, uma transcendência instituída, quer dizer, o enunciador viabiliza a leitura como filtro de construção mútua de sentido. É por esses parâmetros que se sustenta a leitura semiótica dos memes de internet. Logo, as 
imagens dos textos meméticos são consideradas na medida em que são constituídas de uma totalidade de sentido. Esta totalidade é entendida como o conjunto indissociável no qual se soma o texto e o seu contexto.

Uma imagem legendada, como dizem os estudiosos da Comunicação, corresponderia, para a semiótica, a um texto sincrético verbovisual, compondo assim a textualização memética. Aquele que compartilha é o enunciador-destinador, dependendo da posição sintática ocupada pelo sujeito: narrador e interlocutor são exemplos desse câmbio contínuo dos papéis actanciais que admite o sujeito. Quem o receberá será o enunciatário-destinatário. Aos poucos vamos ajustando os ponteiros do relógio teórico para dar conta, semioticamente, das análises dos memes.

E o autor? No caso dos memes, esse último, como já afirmamos, é constitutivamente não biografado. Ele é muitas vezes desconhecido - o meme muitas vezes não apresenta assinatura autoral. No entanto, sabemos que o discurso da memesfera possui uma mira enunciativa. Essa mira está na interpretação esperada do enunciatário. O leitor, co-enunciador do meme, será persuadido a entrar no jogo do compartilhamento do meme apenas pressupondo, sem saber ao certo no que aquela arriscada interação poderá resultar. A Comunicação há muito tempo se interessa por tais tópicos, mas é difícil chegar a um consenso teórico, sobretudo na metalinguagem.

Podemos resumir, grosso modo, que os memes são a primeira forma de contracultura à época da web $2 \cdot 0^{3}$. Seus primeiros exemplares são as mensagens correntes divulgadas por e-mail que eram repassadas em massa (MARINO, 2018). O nome meme, em si, remete à genética. Seu criador, Richard Dawkins (2007), conta que a expressão foi uma maneira de rimar com gene e com creme, o que para nós, semioticistas, é a prova da arbitrariedade dos signos. Entretanto, Saussure diz que há o arbitrário absoluto e o arbitrário relativo (2014, p. 181). Para o pai da linguística, o signo pode ser relativamente motivado. Em francês, o vocábulo même, também foneticamente semelhante, é traduzido em português como "mesmo" ou "imitação", mostrando que o termo de Dawkins dá a razão, o "porquê" do nome de batismo para o objeto principal de sua teoria.

Aproximando-nos do encerramento de nossas apresentações, pelo menos sobre as notas introdutórias, diremos de maneira bastante generalizada que os memes de internet

\footnotetext{
${ }^{3}$ Web 2.0 é o termo que descreve a segunda geração da WWW que reforça o conceito de troca de informações e colaborações dos internautas em sites e serviços virtuais. Fonte: Entenda o que é a web 2.0. Folha de S. Paulo. Tec. 10 de junho de 2006. Disponível em: https://www1.folha.uol.com.br/folha/informatica/ult124u20173.shtml. Acesso em 22 de março de 2020.
} 
são essas imagens da internet "imitadas", tiradas de um determinado contexto e "distorcidas" para os fins humorísticos. Observamos essa "distorção" e "imitação" como princípios parodísticos, que nos parece ser constitutivo do próprio gênero meme de internet.

No campo discursivo da política, esses memes servem como uma forma de protesto contra toda e qualquer ordem estabelecida. É um gênero iconoclasta na medida em que capta e subverte aquilo que é reportado pelas notícias, reportagens etc. Ri-se do absurdo que é mostrado no mundo noticioso em relação aos acontecimentos envolvendo a política e os homens que dela participam, enquanto se compõe a crítica com humor e ironia.

As imagens meméticas têm o poder de destruir ou enaltecer um discurso de autoridade e propor uma nova maneira de leitura dos fatos evocados, não se restringindo à imitação do mundo enunciado, pois subvertem o mundo noticioso. Essas imagens "imitadas" a partir de um primeiro exemplar memético são reapropriadas de diversas maneiras, e cada usuário deixa impressa uma marca de sua identidade na contínua reconstrução do sentido, a qual se somará a tantas outras, formando assim uma verdadeira cadeia memética.

Na política brasileira, o papel dos memes saiu da aparente brincadeira online para se tornar um assunto sério. As eleições de 2014 ficaram marcadas no imaginário popular como as "eleições dos memes" (CHAGAS, 2017). Viktor Chagas, professor e pesquisador da UFF, também fundador da página \#MUSEUdeMEMES ${ }^{4}$, dedicada à pesquisa de memes de internet, afirma que cada vez mais se faz uso de sites e redes de relacionamento virtuais como parte de estratégia de campanha política (p. 175-176). O humor do meme, segundo a pesquisadora israelense Limor Shifman (2014), ajuda na difusão dos conteúdos nele vinculados. Estudar o humor da cultura memética significa “também analisar a sociedade que utiliza como código de interpretação do real, pois o sentido humorístico é estabelecido como efeito de interação social" (CHAGAS, 2017, p. 7).

Portanto, justificamos nosso trabalho pelo uso cada vez mais crescente das redes sociais e dos aparelhos de telefonia móvel com conexão para obtenção e repasse de informações: opiniões, notícias e, claro, memes. Em reportagem do dia 28/08/2019, o

\footnotetext{
${ }^{4} \mathrm{O}$ \#MUSEUdeMEMES é um projeto da Universidade Federal Fluminense (UFF) cujo objetivo é auxiliar pesquisadores, promovendo debates, criando acervos de referência e divulgação científica sobre o tema. Disponível em: www.museudememes.com.br. Acesso em 19 de abril de 2019.
} 
jornal online G1 publicou dados sobre a internet no território nacional. Segundo a matéria $^{5}, 70 \%$ dos brasileiros fazem uso da internet, o que representa cerca de 126 milhões de pessoas conectadas em todo o Brasil, número que indica também que mais de $50 \%$ da população rural e das classes C e D estão hoje incluídas na cultura digital.

Dentro da era da informação, a qual parece se definir pela frase de ordem "tudo e agora", pela velocidade com que as informações circulam, as trocas são feitas de maneira imediata. Passamos $24 \mathrm{~h}$ do dia conectados, recebendo e replicando informações, sem prudência, sem discrição e, muitas vezes, sem o devido lastro factual. O que parece ser verdadeiro provavelmente deve ser. Cria-se, assim, um novo tipo de relação interpessoal e fiduciária entre enunciador e enunciatário, regida por um crer que antecede todo e qualquer saber. E o meme não é exceção a esse encaminhamento na construção do universo do sentido no domínio da web.com.

Shifman $(2014,2019)$ admite que os memes são a maneira mais criativa, divertida e barata de se fazer política. Sabendo que no Brasil temos $92 \%$ dos lares com conexão à internet pelo celular, enquanto apenas $66 \%{ }^{6}$ possuem rede de esgoto, os memes funcionam, de certa forma, para democratizar o debate político entre uma parte da população que antes se encontrava dele apartada, aproximando o cidadão comum conectado e a política (CHAGAS, 2018).

Em estudo $^{7}$ do jornal britânico The Guardian em parceria com a agência de pesquisa Revealing Agency sobre o uso de smartphones em época de eleição, revelou-se que as notícias relacionadas a assuntos políticos internos como o Brexit têm se transformado em peças de entretenimento. A imagem ou o título da matéria podem bastar a título informativo. Em um dos perfis de eleitor analisados durante a pesquisa, constavase que as notícias eram consumidas por memes de internautas, por celebridades influencers e nos perfis dos próprios políticos, mais do que por fontes midiáticas confiáveis. Tudo é válido na corrida eleitoral, até mesmo o uso de memes, destacando o seu estatuto como força ou argumento de persuasão entre o cidadão conectado.

\footnotetext{
${ }^{5}$ LAVADO, Thiago. Uso da internet no Brasil cresce, 70\% da população está conectada. G1. Economia. 28 de agosto de 2019. Disponível em: https://g1.globo.com/economia/tecnologia/noticia/2019/08/28/usoda-internet-no-brasil-cresce-e-70percent-da-populacao-esta-conectada.ghtml. Acesso em 08 de dezembro de 2019.

${ }^{6}$ DADOS do IBGE de 2017 divulgados pelo site da revista Época. Fonte: Agência O Globo. Brasil No Brasil 92\% dos lares têm celular, mas apenas 66\% têm esgoto tratado. Época negócios. Brasil. 24 de novembro de 2017. https://epocanegocios.globo.com/Brasil/noticia/2017/11/no-brasil-92-dos-lares-temcelular-mas-apenas-66-tem-esgoto-tratado.html. Acesso em 15 de fevereiro de 2020.

${ }^{7}$ WATERSON, Jim. Uncovered: reality of how smartphones turned elections into chaos. The Guardian. UK Politics. Disponível em: https://www.theguardian.com/politics/2019/dec/05/uncovered-reality-ofhow-smartphones-turned-election-news-into-chaos. Acesso em 08 de dezembro de 2019.
} 
Chagas admite que o conteúdo dos memes contribui para simplificar as percepções a respeito da realidade, tornando-as até mesmo rasas (CHAGAS, 2018, p. 7). Um meme, examinado na geração do sentido e nos mecanismos de persuasão e de intepretação, mostra-se, entretanto, muito complexo. Eis a função da semiótica e a missão do nosso trabalho: desvelar o que parece que é, não apenas o que é. Esse fundamento da semiótica faz qualquer enunciado se mostrar na sua complexidade.

O nosso corpus foi selecionado a partir de sites de notícia, sites especializados em memes e compartilhamentos de usuários do Twitter. A pesquisa se debruça sobre memes brasileiros de cunho político no período de 2016 a 2019. Os temas sobre os quais escolhemos discorrer em nossas análises foram "Bela, recatada e do lar" e "Fica Temer" devido à grande repercussão desses memes na época de seu surgimento. Todos os memes selecionados são imagens estáticas, isto é, não fílmicas, e os textos são de natureza sincrética verbovisual. Importante observar também o contexto no qual houve a circulação desses memes, quais eram as notícias e os acontecimentos no momento de sua "viralização"8.

Dito isso, reafirmamos que esta nossa dissertação de mestrado se propõe a estudar a construção do ator da enunciação dos memes políticos veiculados na internet, o que faremos através do exame dos mecanismos de construção que nos oferecem a imagem do enunciador, visto como ator da enunciação memética.

Este é um trabalho norteado pelos princípios da Semiótica Discursiva, de fundamento estruturalista, de A. J. Greimas, e apoiado pela teoria tensiva relativa ao sensível, criada e desenvolvida por Zilberberg. Paralelamente, procuramos suporte teórico em outros autores que se debruçam sobre temas tais como o éthos, o efeito de humor e a linguagem sincrética.

Antes de darmos início à nossa discussão, explicaremos a apresentação de nosso trabalho. A dissertação está dividida em cinco partes principais, além desta introdução sobre a nossa pesquisa. Capítulo 1 -O meme; Capítulo 2 - A Semiótica; 3 - Humor e tensividade nos memes de política; Capítulo 4 - Depreensões teórico-analíticas e, por

\footnotetext{
${ }^{8}$ De acordo com a edição online do dicionário bilíngue Collins o verbo "viralizar", do qual o substantivo viralização se deriva, vem da expressão em inglês "to go viral", o que significa tornar algo viral. Pelo dicionário Houaiss (2015), no seu sentido figurativo, diz respeito a um conteúdo que se espalha como um vírus pela internet, se tornando amplamente conhecido pelos usuários da web. Quando um meme "viraliza", isso corresponde a um alto número de acesso e compartilhamento que determinado conteúdo obteve. Disponível em: https://www.collinsdictionary.com/pt/dictionary/portuguese-english/viralizar. Acesso em 13 de abril de 2020.
} 
fim, Considerações finais, Referência Bibliográfica, Lista de referência de sites de notícias e vídeos e Anexos.

No Capitulo 1 - O meme relataremos com mais detalhes o que são os memes, desde sua origem e concepção, destacados no trabalho de Richard Dawkins (2007). Em seguida contemplaremos os memes circunscritos na cultura da web tal qual conhecemos hoje, apoiados nos estudos de Limor Shifman (2014, 2019). Viktor Chagas (2017, 2018), no ponto seguinte, define o papel do meme no debate político atual e discute como o gênero memético é usado como uma poderosa arma de propaganda política direcionada para o enunciatário memético e leitor. Para entender a intertextualidade e a interdiscursividade que permeiam o meme, buscamos em Bakhtin (2011), Fiorin (2018) e Maingueneau (1998a, 2013) as necessárias referências sobre as noções de gênero e os fundamentos de como todo discurso é sempre atravessado pelo de outrem e, além disso, quais os valores que são propostos pelo enunciador e aceitos pelo enunciatário que aparecem no jogo de troca dos enunciados sincréticos dos memes. Yvana Fechine (2018) e Gabriele Marino (2018) concluem esse capítulo nos auxiliando na compreensão dos memes, na adoção de um ponto de vista semiótico de como esse gênero textual é propagável e como é possível conectar uma cadeia memética por um tema ou uma figura ou vários temas e figuras pelo princípio de isotopia (GREIMAS; COURTÉS, 2012). Ressaltamos que os memes são textos figurativos por excelência.

Já no Capítulo 2, dedicado aos pressupostos teóricos, apresentamos, em primeiro plano, a nossa metodologia de análise pela Semiótica Discursiva, fazendo uma breve, porém detalhada, descrição da teoria greimasiana à luz dos estudos de Diana Barros (2002, 2007) e José Luiz Fiorin (1995, 2004, 2007, 2016a, 2016b), aplicando-a em alguns exemplos de análise ao longo do capítulo. Por último, abordamos a questão da enunciação sincrética, com o devido aporte teórico oferecido por Norma Discini (2018a, 2018b), Lucia Teixeira (2009) e Jean-Marie Floch $(1986,2001)$. Trazemos ainda a discussão sobre a noção de éthos do sujeito da enunciação (MAINGUENEAU, 1998a, 2013), noção que reflete a imagem de "si" do enunciador que é supostamente "bem aceita" pelo seu enunciatário. $\mathrm{O}$ ator da enunciação memética, conforme buscaremos demonstrar, despontará como um sujeito de perfil moralizante, crítico, político, um aliado ideológico de determinado segmento social e, por fim, um sujeito com ótimo senso de humor.

Bebemos direto na fonte do humor para embasar o Capitulo 3 - Humor e tensividade nos memes de política a respeito do riso e do cômico nos textos meméticos de orientação política. Baudelaire (1997) nos introduz à teoria do riso visto nas obras 
clássicas da literatura francesa e nas caricaturas do século XIX. Para o poeta e ensaísta sobre a arte do cômico, o riso é algo de satânico que desperta nas pessoas um sentimento de superioridade em relação àquele sobre quem o riso recai. Bergson (2018), por sua vez, vê o riso como uma prática social que necessita do eco de um grupo para ter força cômica. Para o filósofo, o riso consegue suavizar tudo que resta de mecânico na vida social, apontando que rimos por uma necessidade de adequação ao mundo social $\mathrm{x}$ mundo natural. O observador à distância que olha a cena cômica do infortúnio alheio (uma queda, por exemplo) entende que nunca seria capaz de cometer tal deslize ao rir do sujeito que sofreu a queda.

No ponto seguinte, cotejando a ideia de Bergson (2018) de que o inimigo do riso seria a razão, na erupção do sensível que domina o inteligível, relacionamos o cômico aos desdobramentos tensivos indicados por Zilberberg $(2002,2007,2011)$. Os estudos de Zilberberg, que fazem isso dentro da lógica do acontecimento e do exercício, alcançarão rendimento nesta parte do capítulo. Para o semioticista, o acontecimento é da ordem do inesperado, de alta intensidade, de andamento acelerado e sempre concessivo. $\mathrm{O}$ exercício, seu correlato, está na ordem do esperado, maior duração no tempo e no espaço, de andamento lento. $\mathrm{O}$ acontecimento (e seu impacto de vivência) estaria para o instante do mundo noticioso (os discursos, mandos e desmandos que envolvem o universo político) e o meme para o exercício, fazendo rir dos atores políticos evocados e corrigindo-os, ou sancionando-os, pelo humor.

Fomos auxiliados pelo recente trabalho de Mariana Luz Pessoa de Barros (2019) intitulado "Os sentidos da tortura: uma análise semiótica das eleições presidenciais de 2018", no qual a semioticista analisa os discursos de Bolsonaro, na ordem do acontecimento, e como se "normaliza" o discurso outrora considerado como indizível, entre outras formas, através do meme. Discini (2015) nos traz a noção do aspecto télico e de perfil judicativo do sujeito que se apresenta como um crítico feroz no seu modo de enunciar.

No Capítulo 4 - Depreensões teórico-analíticas faremos as análises do nosso objeto. Selecionamos dois temas principais nos quais os memes se baseiam: "Bela, recatada e do lar" e "Fica Temer". As publicações das notícias acompanham os memes durante as nossas análises, uma vez que os próprios memes são fortemente cravados nos contextos. Ou melhor, os memes precisam de outros textos com os quais se relacionam para a compreensão de seu sentido, provando mais uma vez o aspecto intertextual do 
discurso memético. Em seguida, observamos como ocorre a subversão do mundo noticioso para a memesfera.

Nossa dissertação é composta por 22 memes ao total e outros 6 na parte de Anexos ligados aos temas aqui abordados. Dos 22 que estão presentes na nossa pesquisa, 12 foram selecionados para o capítulo de análises. Os memes foram coletados em sites especializados em divulgação de memes como o \#MUSEUdeMEMES e o BuzzFeed, sites de notícias como BBC Brasil e El País, que dedicaram algumas de suas matérias a esses enunciados sincréticos e humorísticos, e em buscas pela internet por memes com temas específicos para compor nosso corpus. Os demais 10, que não fazem parte do capítulo de análise, estão distribuídos ao longo dos capítulos da dissertação como exemplos de procedimento de análise e por julgarmos que um meme ou outro a mais nunca é demais. 


\section{OS MEMES}

\subsection{Um gene em favor da cultura}

O termo meme advém da mesma raiz da palavra mimesis, que designa o ato de assemelhar, de imitar, de expressar a natureza não como ela se apresenta em si mesma, mas como ela é percebida. O nome meme foi dado pelo geneticista Richard Dawkins na sua obra The Selfish Gene, ou o Gene Egoísta (2007 [1976]), traduzindo para o português. Os memes de Dawkins são genes culturais que são repassados de pessoa em pessoa. Para o pesquisador, são exemplos de meme "ideias, slogans, as modas no vestuário, as maneiras de fazer potes ou construir arcos" (2007, p. 330) que são transmitidos seja pela linguagem oral ou pela escrita, garantindo ao meme sua relevância sociocultural.

Diferente da transmissão genética pela reprodução, a transmissão memética se dá pela imitação, pela replicação e pelo contágio - conforme a perspectiva do estudioso. Dawkins (idem) dá o exemplo de um cientista que ao ouvir ou ler uma boa ideia transmitea aos seus colegas e alunos. Se a ideia for aceita, pode-se dizer que ela propaga a si mesma.

Pelo viés apresentado pela teoria genética, os memes (unidade básica de informação cultural) são genes que se espalham tendo os humanos como hospedeiros e são capazes de obter grande sucesso na dispersão cultural. $\mathrm{O}$ autor anteriormente referido dá como exemplo de memes as leis religiosas, as quais podem se propagar e ter enorme adesão durante anos graças a registros escritos. Outro exemplo seria uma melodia popular cujo grau de difusão pode ser medido pelo número de pessoas que a assobia na rua (DAWKINS, 2007, p. 333).

Ainda de acordo com os preceitos de Dawkins, esses genes culturais estão sujeitos a mutações e misturas em caráter contínuo. Se voltarmos ao exemplo dado previamente sobre o cientista e a palestra, cada vez que ele difunde uma ideia nova e a repassa adiante, a pessoa que a escutou irá modificá-la de alguma forma (ibid., p. 334). Isso comprova que, por melhor que ele seja aceito, o meme não se reproduz de maneira fiel, podendo sofrer reajustes.

Dawkins (2007) diz que um meme possui três características principais: fecundidade, longevidade e fidelidade. A fecundidade é a capacidade do meme de gerar cópias; a longevidade é seu tempo de sobrevivência; e a fidelidade é a semelhança que o meme tem da sua forma originária. No caso das criações parodísticas a partir do textofonte, é possível constatar, em relação à fidelidade memética, as relações intertextuais 
que se mantêm entre as alusões parodísticas e o texto-base. Isso, entretanto, é do ponto de vista da semiótica e dos estudos discursivos em geral.

O que o biólogo Richard Dawkins quis provar nos seus estudos diz respeito ao aspecto evolucionista da concepção de meme. Em paralelo à teoria da evolução de Darwin, a qual propunha uma evolução da espécie humana pelos genes, Dawkins pesquisava sobre uma evolução cultural pelos memes, através dos quais valores, costumes e hábitos são transmitidos ${ }^{9}$, retransmitidos, e possuem força para permanecer relevantes por um longo período de tempo.

\subsection{Os memes de internet}

Limor Shifman (2014), por sua vez, observa os memes já inscritos na cultura online. Mais que simples "unidades de imitação", Shifman defende que os memes de internet são um complexo de textos compostos de elementos que só fazem sentido para um grupo específico. Yvana Fechine (2018) define os memes como textos específicos da web, resultado de transformações e compartilhamentos dos usuários feitos de maneira anônima.

São exemplos populares de memes de internet imagens com legenda (textos sincréticos verbovisuais), GIFs, sons e vídeos. No entanto, nem toda imagem ou vídeo que circula pelos meios virtuais de comunicação pode ser considerado meme. É importante fazer uma distinção epistêmica do que é um meme até para nos ajudar na seleção do nosso corpus, evitando escolher um texto sincrético que talvez não corresponda a um meme de fato.

Para fazer tal oposição, Shifman (2014) diferencia primeiramente um meme de um viral. Um meme tem a capacidade de viralizar e atingir um grande número de compartilhamentos. Porém, nem todo meme viraliza. Primeiramente, se um vídeo viraliza não o chamamos necessariamente de meme, e sim de vídeo-viral. No caso dos virais, falamos apenas de um item específico, uma foto-viral, uma propaganda-viral. Trata-se, então, de uma "unidade cultural única" (idem, p. 56). No caso dos memes, independente da forma de expressão na qual se apresentam, são sempre uma coletânea que faz referência a um ou mais textos preexistentes. De acordo com Shifman

\footnotetext{
${ }^{9}$ Richard Dawkins diz que o modo de transmissão de um meme pode ser feito de diversas maneiras, como pela atividade da escrita ou pela oralidade: "é a influência humana de vários tipos, a palavra escrita e a falada, o exemplo pessoal, e assim por diante" (2007, p. 340).
} 
Você pode identificar um único vídeo e dizer 'este é um vídeo viral' sem se referir a qualquer outro texto, mas isso não faria muito sentido ao descrever um meme de internet. Um único vídeo não é um meme de internet, mas parte de um meme - uma manifestação de um grupo de textos que juntos podem ser descritos como o meme $^{10}(2014$, p. 56).

A pesquisadora israelense conseguiu expandir a definição concebida por Dawkins e, ao mesmo tempo, fazer a distinção entre os memes como genes culturais contagiosamente transmissíveis e os memes tal qual os conhecemos e que encontraram seu habitat natural de proliferação viral na cultura digital.

Para Shifman (2014), os memes não são apenas ideias isoladas ou fórmulas que se propagam entre os seus receptores, mas

(a) um grupo de itens digitais que compartilha características comuns de conteúdo, forma e/ou postura, (b) que foram criados com conhecimento mútuo e (c) circulados, imitados e/ou transformados pela internet por muitos usuários ${ }^{11}$ (2014, p. 41).

Se retomarmos a concepção de Dawkins, comparando-a com a definição estabelecida por Shifman, de certo o biologista não fazia referência às novas formas de comunicação introduzidas pelas ferramentas virtuais de disseminação de informação e de compartilhamento presentes atualmente (Facebook, Twitter, Instagram, WhatsApp, para citar algumas). No entanto, essas elucidações iniciais a respeito dos memes são importantes para melhor compreendermos um objeto ainda pouco privilegiado pelos estudos acadêmicos.

Segundo o pesquisador italiano, Gabriele Marino, memes são

i. [...] textos, ii. pertencentes a diferentes substâncias expressivas, geralmente sincréticos, iii. derivados de um processo de intervenção sobre textos preexistentes, iv. de acordo com regras de pertinência e boa formação, v. que se caracterizam por uma eficácia atribuída e reconhecida coletivamente, vi. por um espírito lúdico, vii. por um criador anônimo e viii. por modalidades de difusão que são repetitivas, adaptativas, apropriativas e, em geral, participativas (MARINO, 2018, p. 20, grifos do autor).

\footnotetext{
${ }^{10}$ Do original "You can identify a single video and say 'This is a viral video' without referring to any other text, but this would not make much sense when describing an Internet meme. A single video is not an Internet meme but part of a meme - one manifestation of a group of texts that together can be described as the meme". Tradução nossa.

${ }^{11}$ Do original "[...] a group of digital items sharing common characteristics of content, form, and/or stance, which [...] were created with awareness of each other, and [...] were circulated, imitated, and/or transformed via the Internet by many users". Tradução nossa.
} 
Nesta pesquisa, vamos nos nortear pela definição estabelecida acima por Marino (2018), que resume bem os conceitos aqui previamente explanados por Fechine (2018) e Shifman (2014), e que nos afasta categoricamente da preconcepção equivocada de meras "imagens engraçadas" ou "virais".

\subsection{Os memes da política e a política dos memes}

No início deste capítulo demos maior atenção à história do meme como unidades de transmissão cultural provenientes do campo da genética até chegar ao atual gênero textual e discursivo (BAKHTIN, 2011) tal qual o conhecemos e que circula atualmente na internet. Por agora, vamos nos ater a outro breve e sólido conceito dado pelo criador do termo, o geneticista Richard Dawkins (2007), em sua obra, na qual argumenta que são exemplos de memes bordões, cantigas infantis e habilidades manuais de construções que são retransmitidos entre as pessoas, hospedeiras desse gene, pelo contato.

Viktor Chagas define os memes políticos como

[...] fórmulas discursivas ou artefatos culturais que, a partir de uma interação com seus congêneres, e através de um processo de circulação em diferentes redes sociais, são capazes de despertar ou demonstrar o engajamento político do sujeito ou ainda socializá-lo com o debate público, através de uma linguagem metafórica e orientada à construção de um enredo ou enquadramento próprios, que fazem uso, muitas vezes, de referências da cultura popular (CHAGAS, 2018, p. 10).

Apesar de desconhecermos em qual momento da história da cultura cibernética aconteceu ao certo o marco-zero da memesfera, qual foi o primeiro meme a dar o pontapé inicial à criação dos demais, não nos é estranha a antiga tradição das cantigas de roda repassadas de geração em geração. Pelo contrário, assim como a brincadeira de "escravos de Jó”, podemos dizer que, pelo menos na sua concepção inicial, tal como idealizada por Dawkins, os jingles políticos também podem ser vistos como exemplos de memes antes da era digital. Para Chagas (2018, p. 7), não são raras as expressões criativas que remetem ao nosso folclore político como "Lula-lá" ou "Meu nome é Enéas", que depois de tanto reiteradas em campanhas de rádio e TV acabam sofrendo reapropriações com manifestações de militantes, como a frase "Quércia vem aí"12, que foi pintada em muros

\footnotetext{
${ }^{12}$ Segundo reportagem do jornal Folha de S.Paulo, essas pinturas surgiram nas cidades do Rio de Janeiro e de Belo Horizonte. Na primeira, o ex-governador paulista recebeu uma multa por ter seu nome pintado em
} 
de algumas cidades brasileiras anunciando a candidatura do ex-governador de São Paulo Orestes Quércia. Esses exemplos aqui expostos se adequam à concepção de Dawkins de fidelidade (mantêm graus de aproximação com um texto preexistente), fecundidade (são de fácil reprodução) e longevidade (garantem maior duração na memória) a respeito dos memes.

Chagas $(2018$, p. 7) chama esses exemplos de "manifestações meméticas" que antecedem os memes de internet. Não nos esqueçamos do carnaval, a festa de momo, durante a qual as pessoas parodiavam eventos da política através das conhecidas marchinhas - canções tão populares - ou até das fantasias. O brasileiro já conhecia esse tipo de manifestação política e o adequou à nova capacidade de ampliação de conteúdos políticos pelas redes socais.

Ao abordarmos os memes de internet como um texto, na acepção da Semiótica Discursiva, não é apenas o segmento verbal, ou seja, o chiste, o punch, ou as palavras de ordem de militância política precedidas (ou não) de hashtags (\#), exemplo do \#foratemer, \#foradilma, \#vemprarua, ou as declarações dos políticos durante uma campanha presidencial, a exemplo da famosa frase "GLÓRIA A DEUS" (Figura 3) do candidato Cabo Daciolo no primeiro debate televisivo das eleições de 2018, que importa na confecção do texto memético. A soma do segmento visual ao segmento verbal caracteriza o meme como um texto sincrético, desempenhando importante papel para se chegar ao sentido almejado pelo enunciador. Lembramos que, segundo Barros (2007), texto sincrético define-se como aquele no qual várias manifestações de linguagem interagem na produção da significação.

Tanto o segmento visual quanto o segmento verbal fazem remissão a um personagem ou a um evento da história política brasileira, sintetizando ou personificando “um conjunto de referências sobre o político ou o cenário da política e, de certo modo, recuperam teses sobre o teatro político e a política de opinião" (GOMES, 2014 ${ }^{13}$, apud CHAGAS, 2018, p. 7) com seus personagens caricaturados, ressemantizados, debochados e reificados, com atributos que são inatos aos papéis e ao valor social que possuem. Esses valores são subvertidos nos textos meméticos.

prédio público. Quércia é multado por pichação no Rio. Folha de S. Paulo. Brasil. 02 de fevereiro de 1994. Disponível em: https://www1.folha.uol.com.br/fsp/1994/2/02/brasil/17.html. Acesso em 10 de dezembro de 2019

${ }^{13}$ GOMES, W. Transformações da política na era da comunicação de massa. São Paulo: Paulos, 2004. 
Figura 3 - Meme "Glória a Deus"

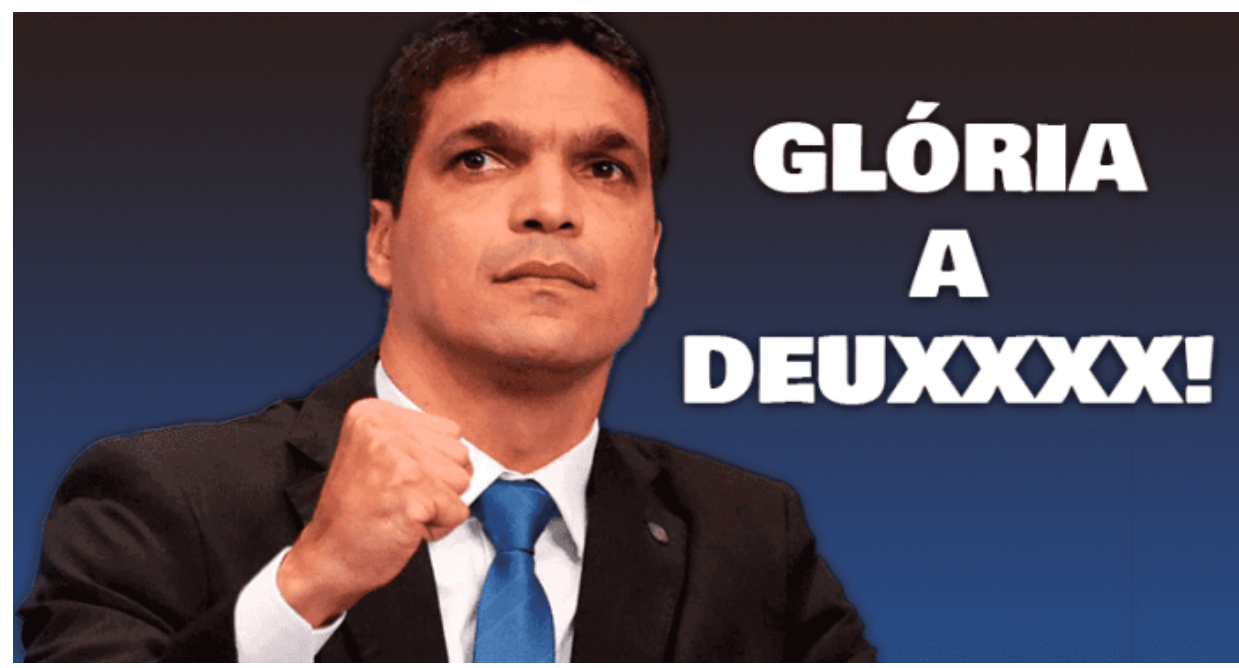

Fonte: https://i0.wp.com/www.informacaodigital.com.br/wp-

content/uploads/2019/03/daciolo.png?resize=696\%2C392\&ssl=1. Acesso em 09 de dezembro de 2019.

Figura 4 - Meme "Barbie e o PT"

"O PT quase destruiu a minha vida"

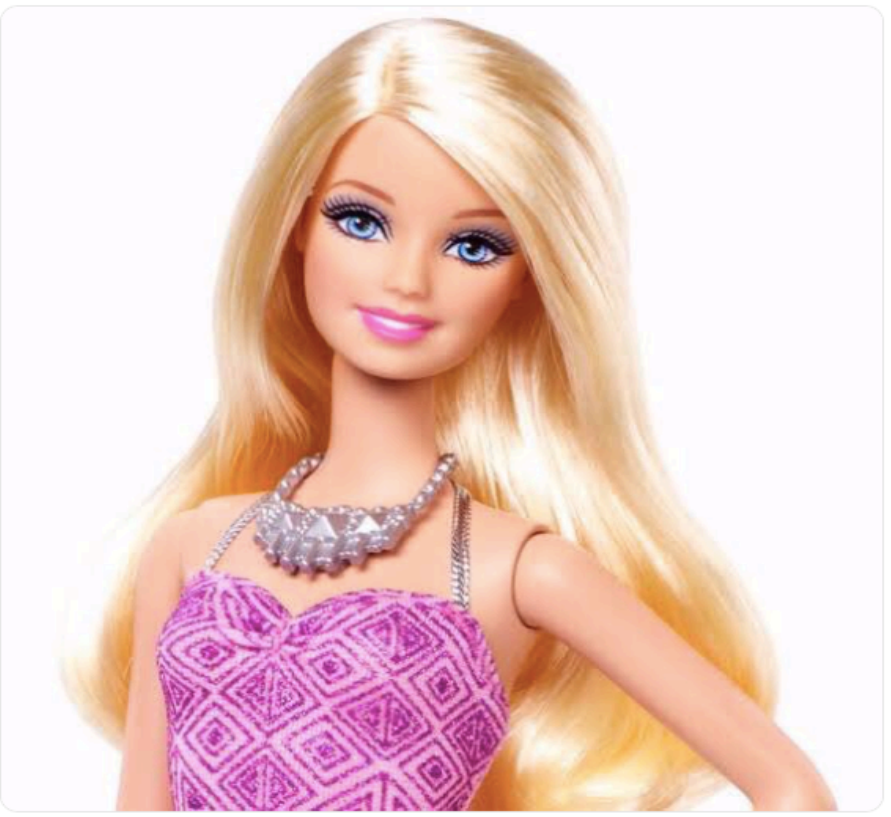

Fonte: https://twitter.com/Itspedrito/status/1050018141630332928. Acesso em 10 de dezembro de 2019. 
Figura 5 - Meme "Barbie e o racismo"

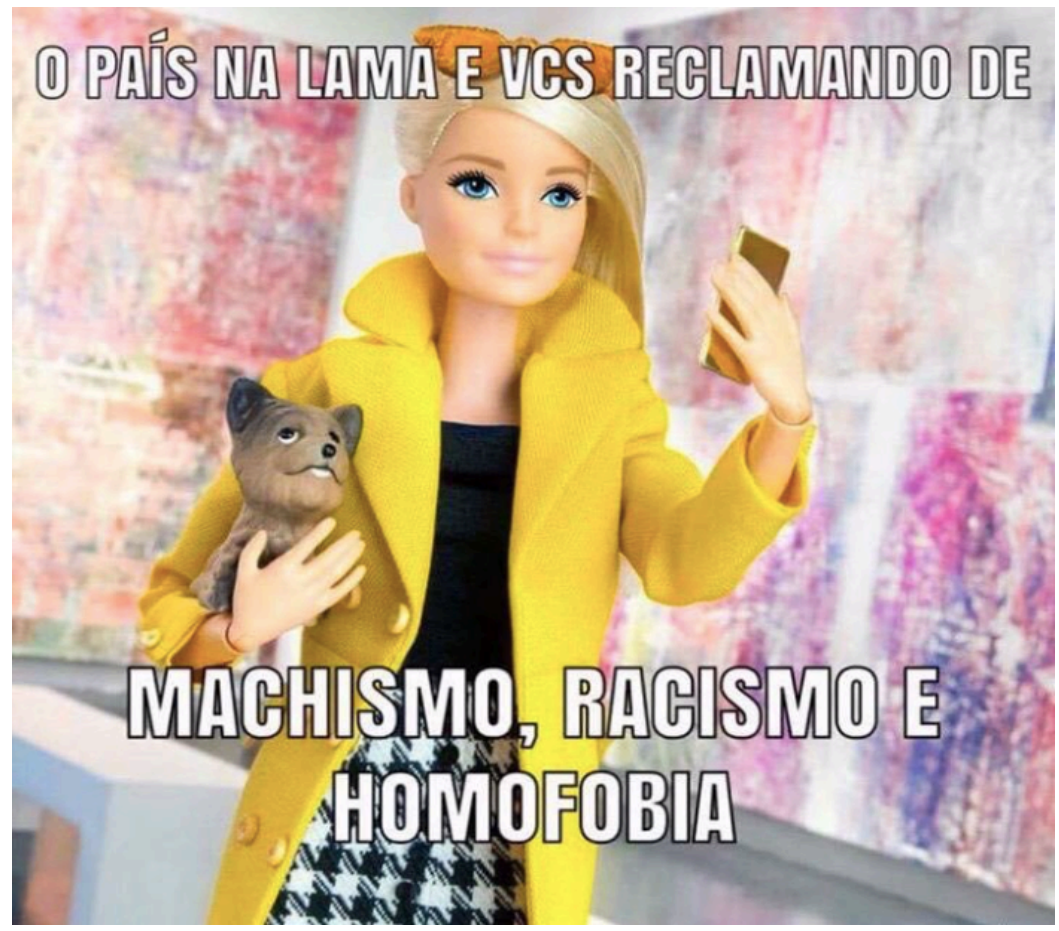

Fonte: https://twitter.com/nobrejoao/status/1050420365376282624. Acesso em 10 de dezembro de 2019.

Figura 6 - Meme "Barbie e a Venezuela"

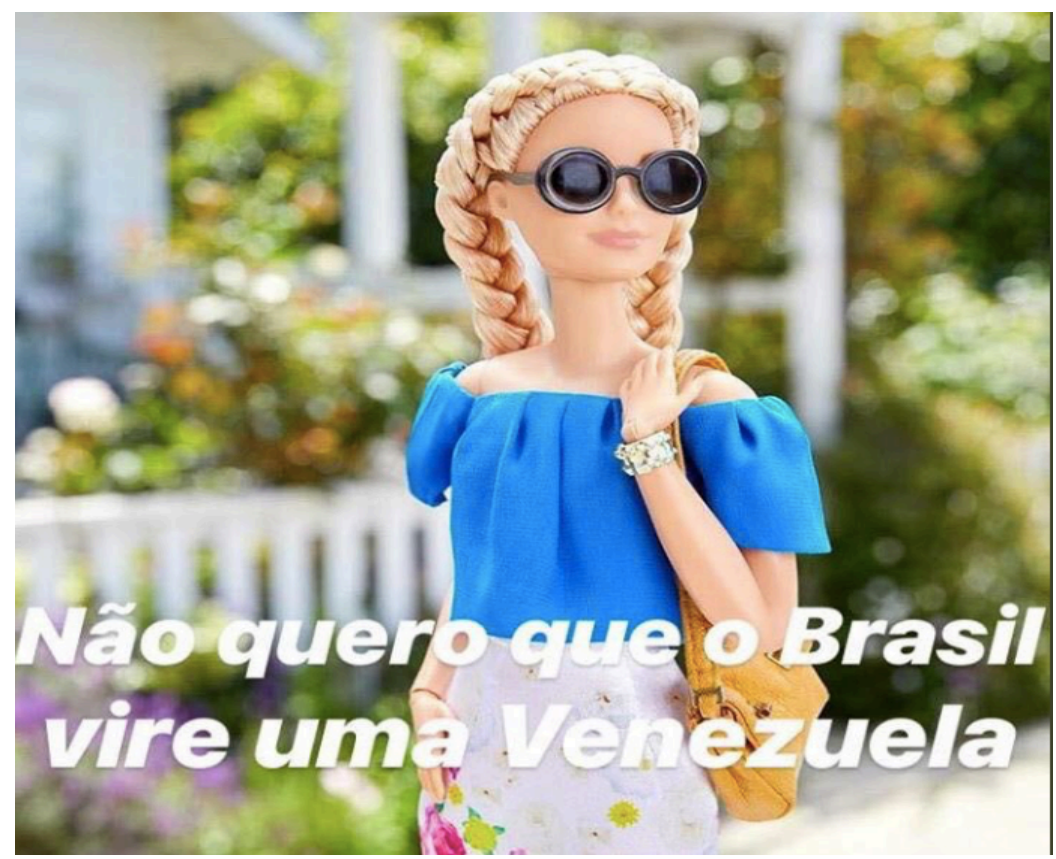

Fonte: https://twitter.com/nobrejoao/status/1050420365376282624. Acesso em 10 de dezembro de 2019. 
O humor dos textos sincréticos pertencentes à memesfera se aproxima das características encontradas na categoria jornalística chamada fait divers (CHAGAS, 2017), a qual versa sobre amenidades ou eventos fortuitos. Conrado Mendes (2013), na sua tese de doutorado sobre a tensividade no fait divers, explica, a respeito dessa prática comum dos jornais cotidianos, que "o fait divers constitui-se [...] como o outro, o não eu. Por esse prisma, ele pode ser tomado como uma alteridade que diverte, que entretém, que faz rir e da qual se escarnece" (ibid., p. 22).

Na coleção de memes "Barbie de bem", surgida durante as eleições de 2018, observa-se a boneca Barbie, que figurativiza uma personagem burguesa incapaz de reconhecer seus privilégios sociais, tecendo comentários sobre o Partido dos Trabalhadores (PT), a luta das pessoas negras, os homossexuais e a Venezuela, denotando total ignorância a respeito de algumas pautas sociais. Como os memes são sobretudo contexto, como diz o \#MUSEUdeMEMES, os da "Barbie de bem" acompanham um episódio, um fait divers, que ganhou notoriedade pelos principais meios de imprensa. Baseava-se na imagem de uma babá usando uniforme de trabalho acompanhando um casal de pais que compareceram à manifestação de 2016 contra a "roubalheira" do Partido dos Trabalhadores e a favor do impeachment de Dilma Rousseff e da permanência dos privilégios da classe econômica mais alta. $\mathrm{O}$ meme, pelo seu caráter humorístico, dá outra coloração ao impacto que a cena-fonte traria consigo.

Ao encontro de Mendes, Chagas (2017) afirma que a banalização de fatos e personalidades da política, na forma como é retratada nos memes, como a piada "pastelão" e o kitsch, é uma nova forma encontrada de se fazer propaganda política, de falar sobre esse outro sobre o qual o humor recai, alinhada às novas tecnologias de circulação da informação. Para o pesquisador

Na lógica dos memes, o humor flerta com o kitsch: a predominância de uma linguagem popular e de apelo visual que banaliza, se não ridiculariza o político, compõem uma estratégia (ou contra-estratégia, na medida em que circulada pelo "internauta casual") de aproximação, que exalta o fait divers, a piada situacional, os elementos de cultura popular, e que contrasta e compete com a radicalização ou mesmo a disputa retórico-discursiva da militância espontânea em torno de 'formas morais'. Funcionando como elementos de crítica e banalização da política, ao mesmo tempo em que facilitam a polarização partidária, estes memes giram em torno de temas que estão na agenda pública da política nacional. Eles combinam distinção e identidade, e parecem assumir, para si e à sua maneira, a tarefa de resolver o problema de adequação do discurso aos novos meios (CHAGAS, 2017, p. 181). 
Essa identidade que os memes parecem assumir, a qual Chagas (2017) menciona, diz respeito à individualização dos "grupos textuais" (SHIFMAN, 2019, p. 48). É nesses grupos que opiniões políticas partilhadas se misturam com vozes particulares que expressam suas emoções e pontos de vista através dos memes.

Desta forma, memes se tornaram peças importantes de campanha política e de polarização no momento em que as emoções expressadas por eles podem não ser necessariamente a de outro grupo de reconhecimento ideológico diferente, podendo haver desavenças partidárias entre os participantes da interação de troca que se estabelece.

Shifman (2014, p. 120-122) afirma que os memes foram usados mais fortemente na política durante a eleição presidencial de 2008 dos Estados Unidos, a qual a pesquisadora chamou de "primeira campanha 2.0". Era a primeira vez que um conteúdo totalmente gerado por internautas anônimos estava sendo usado, mobilizando apoiadores e militantes de uma "maneira sem precedentes" (ibid.). Na época surgiu o famoso bordão “YES WE CAN", endossando o candidato americano Barack Obama. Os usuários do Facebook passaram a colocar esse bordão à frente da foto de perfil da rede social, indicando seu posicionamento político para a lista de contatos da rede.

Conforme já reiteramos, é impossível saber qual o primeiro exemplo de texto "meme de internet" que serviu de modelo a fim de se chegar a conclusões específicas sobre a sua composição. Quer dizer, quais características esse tipo de texto deve apresentar para de fato ser reconhecido como pertencente ao gênero discursivo meme. No entanto, sabemos que qualquer pessoa conectada e com os devidos aplicativos de redes sociais e de tratamento de imagem instalados no celular não irá titubear ao se deparar com um desses enunciados sincréticos numa de suas mais variadas formas de apresentação. Esse cidadão provavelmente entenderá que faz parte do gênero meme certa estabilidade do dizer, que compõe o estilo do meme (DISCINI, 2012). O leitor-observador do meme vai compreender as relações de intertexto que o gênero mantém com outro texto, com outro discurso. O outro texto e discurso pode ser uma notícia midiática ou um personagem do espectro político.

No próximo ponto deste capítulo de dissertação, investigaremos, apoiados nos estudos de Bakhtin (2011) e Fiorin (2018), a noção de intertexto nas manifestações textuais meméticas, aplicando alguns conceitos-chave a respeito do gênero meme de internet por nós explorados anteriormente. Em seguida, abordaremos de maneira breve a propagabilidade do meme baseada nas contribuições acadêmicas de Fechine (2018) e Marino (2018). 


\subsection{A intertextualidade}

\subsubsection{Gênero, discurso e interdiscurso}

A respeito do gênero meme de internet, destacamos que todo texto memético parte da modificação de um texto prévio. Como diria Marino, a própria existência dos memes exige a transformação do texto-fonte (2018, p. 25). Ainda de acordo com a concepção de Shifman (2014, p. 41), os memes são criados com conhecimento mútuo. Para o meme ser bem-sucedido em sua missão de disseminação, é importante que tanto quem o compartilha (sujeito 1) como com quem o meme é compartilhado (o sujeito 2) conheçam o conteúdo-fonte ao qual o meme faz referência. Esse conteúdo-fonte pode dizer respeito tanto a algum fato (como o exemplo do meme da Barbie e sua relação com a participação da babá no protesto) ou com outro meme. Segundo Fontanella (2009), é dessa maneira que os grupos de usuários se apropriam de repertórios culturais aos quais os memes fazem alusão e, através do conteúdo das informações trocadas, tecem laços que os fazem se reconhecer e afirmar "seus valores e repertórios interpretativos compartilhados" (FONTANELLA, 2009 p. 6). Assim, quanto mais difundido for o conteúdo de origem, maior impacto terá a intertextualidade e, consequentemente, maior impacto terá o meme.

Sobre a questão da apropriação do repertório popular, além do conhecimento compartilhado e do meio de circulação, para caracterizar um meme é necessário observálo pela relação de intertextualidade que possui com outros textos.

Retomemos o primeiro conceito de Shifman (2014, p. 41) sobre o que são memes: "(a) um grupo de itens digitais que compartilha características comuns de conteúdo, forma e/ou posicionamento" (grifo nosso). A autora utiliza o termo stance, o qual traduzimos aqui como posicionamento, cuja definição exata é, segundo o dicionário online da universidade de Cambridge, "uma maneira de pensar sobre algo, especialmente expressa em uma opinião declarada publicamente"14.

Como afirma Fiorin (2016b, p. 52), “foi Bakhtin que tratou pela primeira vez do problema do dialogismo, ou seja, do fato de que sob as palavras de alguém ressoa a voz de outrem”. Por essa perspectiva é possível dizer, para os estudos discursivos, que os memes políticos são uma maneira de se fazer certa crítica através da voz que é delegada

\footnotetext{
${ }^{14}$ Link do verbete em inglês https://dictionary.cambridge.org/pt/dicionario/ingles/stance. Acesso em 6 de agosto de 2019.
} 
ao narrador, às figuras actanciais que surgem no nível semio-narrativo do percurso gerativo e que depreendem o ator da enunciação, no nível discursivo, cujas características são reveladas no interior do texto.

Sobre a intertextualidade, Julia Kristeva introduziu nos estudos da linguagem e do discurso o conceito de intertexto a partir da ampliação da noção de dialogismo ${ }^{15}$ proposta pelo formalista russo Mikhail Bakhtin (2011). Pela perspectiva bakhtiniana, entende-se por dialogismo as relações intertextuais e interdiscursivas estabelecidas entre textos e enunciados (FIORIN, 2018, p. 57). Podemos então afirmar que os memes são exemplos de intertextualidade e de interdiscursividade, realizadas por meio de textos sincréticos.

Os textos, segundo Fiorin (2018), a respeito do conceito elaborado por Bakhtin, não são exclusivos da categoria verbal, pois expressam "qualquer conjunto coerente de signos" (p. 57), admitindo-se a existência também de textos não-verbais que dialoguem com outros textos. Define-se então como intertexto a relação dialógica de um texto no interior de outro texto, porém um texto possuindo uma existência independente do outro, mas ainda assim mantendo, entre eles, em algum grau de contato, um encontro entre duas materialidades linguísticas (p. 58).

Os memes de internet (texto de apropriação), por manterem proximidade com fatos cotidianos e as notícias veiculadas na mídia de grande circulação (textos independentes), serão observados por nós, conforme sugerido por Bakhtin, pelas relações intertextuais e interdiscursivas, delegação de vozes admitidas pelos sujeitos na comunicação, pelas retomadas de figuras e temas, como tópicos mantidos e subvertidos a partir dos textos de base.

Na noção de texto de Dominique Maingueneau (2013, p. 65), todo texto pertence a uma categoria de discurso, ou melhor, a um gênero de discurso. O linguista entende como gênero de discurso "[...] atividades sociais que [...] são submetidas a êxito" (p. 72). Isso não quer dizer que os gêneros estejam à disposição do enunciador para que ele monte o seu discurso seguindo os moldes já pré-definidos como jornalístico ou literário. Os gêneros, defende Maingueneau, têm uma finalidade reconhecida. O autor, citando Charaudeau, diz que o gênero de discurso precisa responder primeiramente à seguinte

\footnotetext{
15 Segundo José Luiz Fiorin (2018, p. 57) o termo dialogismo não figura na obra de Bakhtin, mas foi empregado por Julia Kristeva para substituir o termo intertextualidade. No entanto, ela o fez de maneira equivocada, pois não faz uma distinção entre texto e enunciado.
} 
questão: "Estamos aqui para dizer ou fazer o quê?" (CHARAUDEAU, $1995^{16}$ apud MAINGUENEAU, 2013, p. 72). Ao responder à pergunta, determina-se o objetivo dos enunciados. A partir de então o enunciatário pode ter um “[...] comportamento adequado ao gênero de discurso utilizado" (idem, ibid.). Bakhtin (2011) explica que

Os enunciados, produtos da enunciação, [...] refletem as condições específicas e as finalidades de cada referido campo [da atividade humana] [...]. Esses três elementos - o conteúdo temático, o estilo, a construção composicional - estão indissoluvelmente ligados no todo do enunciado e são igualmente determinados pela especificidade de um determinado campo da comunicação. Evidentemente, cada enunciado particular é individual, mas cada campo de utilização da língua elabora seus tipos relativamente estáveis de enunciados, os quais denominamos de gêneros do discurso (BAKHTIN, 2011, p. 261-262, grifo do autor).

O enunciado, para Bakhtin, como descreve Fiorin (2018, p. 57), é uma posição assumida por um enunciador e essa posição aponta para um sentido pretendido por ele. $\mathrm{O}$ enunciador, pressuposto e instalado no enunciado, declara-se como dotado de certos valores e assume um posicionamento que se entende por um simulacro julgador. No caso dos memes de internet, temos um enunciador que incorpora determinado posicionamento social perante o público a quem o discurso é endereçado.

O termo egoísta dado aos genes culturais, assim como também são denominados os memes por Richard Dawkins em sua obra O Gene Egoísta (2007), não é um adjetivo a eles atribuído de maneira arbitrária. Os genes meméticos não possuem a finalidade de se popularizar. Eles agem de maneira independente, à procura de meios onde terão ampla recepção. Eles se replicam "pela palavra falada e escrita, auxiliada por uma boa música e pela grande arte" (ibid., p. 331).

Quanto aos exemplares meméticos que circulam pela internet, Shifman afirma (2014, p. 41) que eles têm sua mira intencional no grupo com o qual eles serão compartilhados. Através do discurso, eles tentam convencer ou manipular por estruturas participativas, definindo assim quem é o seu leitor-enunciatário, e, como elemento chave, o tom (normalmente humorístico) e o estilo dos enunciados.

Shifman diz que os memes são unidades criadas na atenção, ou melhor, na pressuposição do outro. Deste modo, é permitido aos sujeitos envolvidos nessa comunicação, de troca ilimitada, que "os participantes construam simultaneamente sua identidade e sua afiliação a um grupo maior"17 (SHIFMAN, 2019, p. 47).

\footnotetext{
${ }^{16}$ CHARAUDEAU, P. Une Analyse sémiolinguistique du discours. In Langages, n. 117, 1995, p. 102.

17 Do original "Memes enable participants to simultaneously construct their individuality and their affiliation with a larger community". Tradução nossa.
} 
Nos grupos, equivalentes aos círculos sociais, como afirma Bakhtin (2011), de família, amigos, conhecidos, há sempre enunciados investidos de autoridade nos quais sobressai o tom "[...] como as obras de arte, ciência, jornalismo político, nas quais as pessoas se baseiam, as quais elas citam, imitam, seguem" (ibid., p. 294).

Ao considerarmos a experiência individual desenvolvida a partir de uma troca constante e de forma contínua com os enunciados do outro, é correto afirmar que nosso discurso é repleto de palavras do outro (BAKHTIN, 2011, p. 294). Os memes inclusive. Essas palavras do outro que ressoam na nossa, aponta Bakhtin, “[...] trazem consigo a sua expressão, o seu tom valorativo que assimilamos, reelaboramos e acentuamos" (p. 295).

O tom de que fala Bakhtin, para Maingueneau (2013, p. 107), diz respeito à construção da representação do corpo do enunciador. É o éthos, tomando o exemplo da retórica tradicional, que revela, por meio da enunciação, a "personalidade" do enunciador. Através do discurso, a esse corpo do enunciador são atribuídos um caráter e uma corporalidade. Esta, segundo Maingueneau (idem, p. 108), corresponde a uma “compleição corporal" e um modo de se movimentar no espaço social. Já o éthos, por sua vez, indica a "disciplina do corpo estendido por intermédio de um comportamento global". Este éthos se impõe "pela sua maneira de dizer" que remete a uma "maneira de ser" no mundo, "à participação imaginária de uma experiência vivida" (ibid.).

O caráter e a corporalidade, defende Maingueneau (2013), que se materializam no éthos do enunciador, são percebidos por meio de representações sociais, valorizadas ou desvalorizadas, sobre as quais a enunciação se apoia (idem, 2013, p. 108). Ou seja, tais valores são observados na axiologia do enunciado, na imanência do próprio texto.

Se partirmos do pressuposto de que os textos do gênero discursivo meme advêm de um texto gerador e que a partir dele outras modificações podem ser feitas pelos internautas, podemos seguramente nos lançar numa generalização de que os memes nunca são uma produção totalmente singular, pois formam outros vários textos devido ao seu caráter "maleável”. Desse modo, memes são sempre produzidos em série. Porém, em toda a série, há um único enunciado expresso pelo texto memético. A voz do enunciador é aquela que repercute, é "um eco de uma expressão individual alheia" que se torna a palavra do outro como representante da "posição valorativa determinada" (BAKHTIN, 2011, p. 295) no enunciado.

Os gêneros estão em constante mudança. De acordo com Fiorin (2018, p. 72), quanto mais as atividades humanas vão ficando complexas, mais se tem a necessidade de criar novos gêneros do discurso e de se abandonar outros por "desuso", como diria 
Darwin em sua teoria da evolução. Os gêneros vão adquirindo um novo sentido. Por exemplo, com o advento da internet, surgiram o chat, o blog e o e-mail (FIORIN, 2018, p. 73). Os memes de internet nasceram das novas formas e atividades surgidas em uma vida cada vez mais voltada para as relações virtualizadas. Assim, novos modos de observar e conceitualizar a realidade se fazem mister, o que implica "[...] o aparecimento de novos gêneros e a alteração dos já existentes" (ibid., p. 77).

Os memes políticos se assemelham ao gênero charge, ao fait divers e à caricatura, mas se distancia de todos eles pela forma participativa que os constitui. É a nova realidade da internet que fez criar esse novo gênero, realidade a qual, além de apreendida, é replicada, inventada, imitada, recriada e, sobretudo, compartilhada.

\subsubsection{A propagação na memesfera: replicação, invenção, imitação e recriação ${ }^{18}$.}

Os memes formam o que Fechine (2018) denomina cadeias meméticas: "agindo necessariamente como 'coleções' de textos, os memes formam arranjos complexos de conceitos e comportamentos [...]"19 (p. 4). Nelas estão presentes o texto gerador, as suas derivações parodísticas e o ponto de vista adotado pelo enunciador do texto. Nessa serialização pouco se sabe quais são os memes “de chegada" e os de "partida”. Quer dizer, através das semelhanças entre eles, podemos constatar que eles são pertencentes a um mesmo sintagma interdiscursivo, embora seja difícil distinguir qual o original, o "protomeme", por assim dizer, e os que a partir dele foram gerados. Os textos mantêm entre eles uma relação de intertextualidade, como explicam Fiorin (2018) e Bakhtin (2011).

Para se constatar a intertextualidade é necessário entender as estruturas do textobase a fim de observar como essas apropriações e transformações oferecem um novo modo de leitura. Além disso, há de se observar o texto na sua totalidade e nas suas manifestações, tanto no plano de conteúdo quanto no plano de expressão, pois, para a semiótica, como diria Floch (2001), ambos possuem uma reciprocidade presumida, já que um não existe sem o outro.

Yvana Fechine $(2018$, p. 2) afirma que memes são “[...] textos específicos da web. Resultados da disposição dos internautas em transformar e compartilhar qualquer forma

\footnotetext{
${ }^{18}$ Do original: réplication, invention, imitation e récréation. Tradução nossa.

19 Do original "Agissant nécessairement comme des 'collections' de textes, les mèmes forment des arrangements complexes de concepts et de comportements qu'on peut appeler des chaînes mémétiques". Tradução nossa.
} 
que aparece e é difundida pela internet, em geral de maneira anônima". Nessa forma de modificação em série de um texto, elementos se repetem e "fabricam" uma cadeia memética a partir de um texto-base. Esses elementos são a "parte" de um "todo" que forma uma série (ibid., p. 4).

Para que essa serialização ocorra, segundo Fechine (2018), deve haver uma transformação entre as unidades, já que, se os elementos fossem iguais, não poderíamos falar em cadeia de memes - nas quais os textos se apresentam de modo diferente uns dos outros, mas ainda assim possuem algum elemento em comum que os conecta.

Conforme a semioticista explica, a primeira maneira de fazer essas relações entre textos pertencentes ao mesmo sintagma é pelo princípio de analogia de Ferdinand Saussure (2012 [1916]), em que conseguimos ver essa mudança de um estado de organização a outro, formando um outro tipo de sistema por um meio criativo. O mestre genebrino explica que a analogia “[...] considerada em si mesma, não passa de um aspecto do fenômeno de interpretação, uma manifestação da atividade geral que distingue as unidades para utilizá-las em seguida" (ibid., p. 223). Falando de forma e sistema, o que Saussure quis dizer, e que também é ressaltado por Fechine, é seu modo de entender a analogia como um processo capaz de engendrar outras formas "mais ou menos decomponíveis" (ibid.).

Ao afirmarmos que os memes são formados por partes de um sistema maior, as cadeias meméticas, Marino (2018), no cotejo com a proposta de Fechine (2018), aponta que a maior característica dessas expressões textuais, os memes, é a de possuir "ganchos sintáticos" (fórmula, modelo ou sistema) e "ganchos semânticos" (um elemento marcante que atraia o enunciatário, como por exemplo as figuras do nível discursivo) que despertem um engajamento por parte do usuário para transformar o texto, conferindo aos memes o aspecto de propagáveis.

O autor se refere aos textos "miméticos", como ele mesmo denomina, como "práticas de reprodutibilidade" ou uma bricolagem cibernética que "[...] são simbolizadas pelo recorte de amostras (samples), remixes e remakes" (MARINO, 2018, p. 16). Falaremos um pouco mais sobre essas três últimas características.

O sampling, como o trecho de música, corresponde a partes que são cortadas de um texto preexistente e colocadas em outro. Marino (ibid.) chama essa prática de reinterpretação apropriativa. O remixing, ou reinterpretação manipulativa, ocorre quando há modificação de um texto preexistente "em relação a um de seus componentes estruturais" (ibid.). É a transformação da forma, feita de maneira análoga, de que nos fala 
Fechine (2018). O remaking, reinterpretação propriamente dita, seria a recriação de um texto já existente, mas expresso de uma outra forma.

Fechine (2018), por sua vez, alarga essas três características das práticas de reprodutibilidade do memes propostas por Marino (2018) e nos apresenta a estrutura elementar simples de um quadrado semiótico da propagação do conteúdo memético, colocando as seguintes categorias em cada polo do quadrado: semelhança $\left(\mathrm{S}_{1}\right)$, diferença $\left(\mathrm{S}_{2}\right)$, não-diferença (não- $\mathrm{S}_{2}$ ) e não-semelhança (não- $\left.\mathrm{S}_{1}\right)^{20}$. Nos eixos da parte superior do quadrado, em relação de contrários, estão a /semelhança/ e a /diferença/. A /semelhança/ implica a replicação, uma imitação completa do texto tal como ele aparece, quase semelhante ao original. O seu correlato de contrariedade seria a /não-semelhança/. Se na /semelhança/ existe a replicação completa, na /não-semelhança/ teremos a variação parcial do texto de origem, um remaking para usarmos a metalinguagem de Marino (2018), ou a recriação tout court como a denomina Fechine (2018).

Já a /diferença/, em oposição semântica à /semelhança/, é a variação completa do texto, por possuir poucos pontos de contiguidade com o texto-base. Na sua relação de contrariedade, teremos a /não-diferença/, que é uma repetição parcial, também em relação de complementaridade com a /semelhança/.

O quadrado semiótico da Semelhança x Diferença ficaria disposto da seguinte forma:

Figura 7 - Quadrado Semiótico Semelhança x Diferença

Semelhança

REPLICAÇÃO

Repetição completa

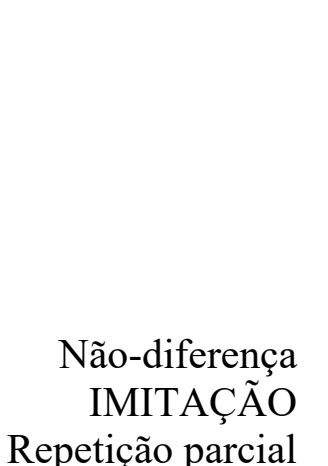

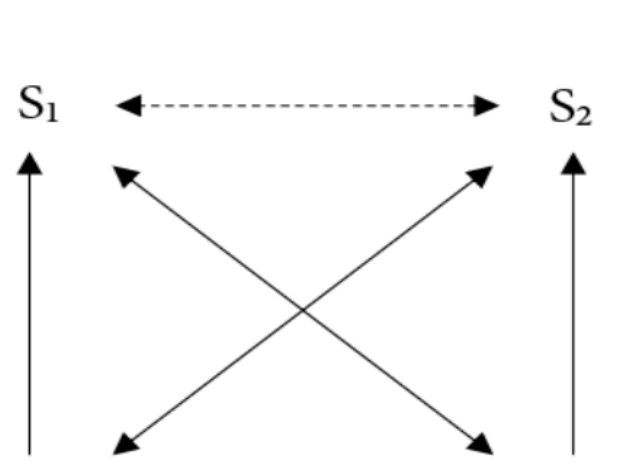

não- $S_{2}$

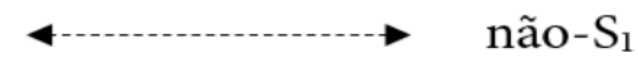

Não-semelhança

RECRIAÇÃO

Variação parcial

Fonte: Fechine (2018). Adaptação nossa.

${ }^{20}$ A metalinguagem proposta pela autora provém do francês similitude, différence, non-similitude, nondifférence. Os termos que apresentamos na dissertação são de tradução nossa. 
Nosso interesse com essa pesquisa não é fazer uma topologia dos memes, mas apenas apontar aqueles que são pertencentes ao mesmo "tópico discursivo" 21 , ou pelo princípio das isotopias, tanto temáticas quanto figurativas, que nos indiquem que os memes dos quais tratamos ("Bela, recatada e do lar", "Fica Temer") fazem parte da mesma cadeia, apesar de um meme possuir uma forma diferente de sua "cópia", por assim dizer. Essas considerações são feitas uma vez que os memes, como já levantamos, não possuem um formato predefinido ou estanque; eles possuem, entre si, porém, alguma ancoragem que nos faz constatar "a olho nu" as relações intertextuais com o texto-base que são ali preservadas.

Numa lógica de interação virtual, acreditamos que um enunciatário não compartilharia aquilo que ele não tivesse compreendido ou que não soubesse muito bem do que se tratava. O contexto, para a semiótica, permitindo-nos avançar um pouco no próximo capítulo da nossa escrita, que aborda a teoria standard, seria um conjunto de textos que acompanha a unidade sintagmática da qual depende a significação (GREIMAS; COURTÉS, 2012, p. 97).

Um meme, como texto, evoca significativamente o seu contexto; ou melhor, o meme vem de um outro texto que o subjaz, na concepção semiótica, ou a intertextualidade não seria compreendida. Nesse caso, o meme falharia na sua missão de propagação. Por constituírem um gênero subversivo, os memes surgem a partir de piadas, discursos e fatos do mundo noticioso, perdendo assim o caráter original desses gêneros textuais e dando origem a outro, no caso, o gênero meme. $\mathrm{O}$ meme seria então uma espécie de gênero secundário, pois ele é transposto, quer dizer "[...] é colocado em outro contexto, em outra esfera de atividade" (FIORIN, 2018, p. 80) na qual o cidadão comum conectado pode fazer as alterações necessárias nessa transposição de um gênero a outro.

O princípio de isotopia para Greimas e Courtés (2012, p. 275-276) é senão uma repetição no decorrer de uma cadeia sintagmática que confere homogeneidade ao discurso-enunciado. A recorrência das categorias sêmicas ou dos traços semânticos distribuídos ao longo do texto levam a um modo de interpretação determinado. Sendo assim, para Fiorin (2016b, p. 112), o que garante a um texto coerência semântica, ou um modo de leitura dirigido, é a iteratividade desses traços. Essas isotopias podem ser figurativas ou temáticas. Estes dois tipos remetem a uma estratégia do enunciador para

${ }^{21}$ Yvana Fechine apresenta a ideia de "Tópico discursivo" que diz respeito ao assunto, à ideia central tratada na cadeia memética. 
chamar atenção do enunciatário para “[...] aspectos da realidade que descreve ou explica” (FIORIN, 2016b, p. 120).

Como um texto pode apresentar caminhos de leituras diferentes, podemos chamar esses tipos de texto, que são “abertos a interpretações múltiplas”, de pluri-isotópicos. No caso de pluri-isotopia, dizem Greimas e Courtés (2012, p. 277), ocorre o emprego de conectores onde várias isotopias figurativas correspondem a uma quantidade igual de isotopias temáticas.

Nesta mesma perspectiva, Yvana Fechine (2018) defende que o caráter pluriisotópico é a pedra de toque das transformações de sentido do texto memético. Segundo a autora "Um meme só é portanto o que ele é - um meme - em relação a um outro meme ao qual se liga através de um conector de isotopia",22 (p. 9).

Um dos nossos interesses em fazer um trabalho sobre memes à luz da Semiótica Discursiva é poder observar essa ligação dos memes "semelhantes" de uma cadeia sintagmática memética através do princípio de isotopia, dos temas e figuras que são recorrentes no patamar mais superficial do percurso gerativo. Segundo Fiorin (2016b, p. 92), todo texto temático investido figurativamente, como é o caso dos memes políticos, possui figuras que são explícitas ao tema. Os memes são textos figurativos por excelência, por isso criam um efeito forte de realidade. Trataremos com mais detalhes da questão das figuras e dos temas nos memes da política, os quais surgem no nível da semântica discursiva, mais à frente, no capítulo sobre a Semiótica, bem como no de análises. Marino (2018) nos diz que através do estruturalismo da Escola de Paris é admissível se criar "mapas" temáticos e "mapas" figurativos para melhor relacioná-los e agrupá-los num mapeamento a partir de uma perspectiva semântica.

Ao partirmos do estudo de Marino (2018), os memes por nós analisados, que se ligam à mesma cadeia sintagmática pelos temas e figuras que têm em comum, foram colocados em cada ponto das análises no capítulo das depreensões teórico-analíticas nas seguintes oposições: "liberdade x opressão" para abordarmos os memes da cadeia "Bela, recatada e do lar" e "identidade x alteridade" para memes do "Fica Temer". Desse modo, delimitado nosso objeto de pesquisa, coloca-se o capítulo seguinte sobre a Semiótica Discursiva e seu arcabouço teórico, nos quais embasamos e norteamos nossa pesquisa.

\footnotetext{
${ }^{22}$ Do original, “Un mème n'est pas ce qu'il est que - un mème - par rapport à un autre mème auquel le rattache un connecteur logique”. Tradução nossa.
} 


\section{A SEMIÓTICA}

Para os pesquisadores do \#MUSEUdosMEMES, memes são, sobretudo, contexto. Os memes políticos no Brasil surgem em concomitância a algum fato marcante na história recente da política brasileira. $\mathrm{Na}$ ocasião da abertura do processo de impeachment da presidente Dilma Rousseff, a revista É poca ${ }^{23}$ disse que "o brasileiro tem imensa capacidade de enfrentar, com humor, suas maiores adversidades". Todo o período, que marca um momento frágil da política brasileira, pôde ser acompanhado por usuários que ironizavam, chacoteavam e criticavam o processo de destituição da presidente eleita através de memes de internet. $\mathrm{O}$ reconhecimento do contexto convocado pelo texto memético é fundamental à sua compreensão.

Para o fundador da Escola de Paris, A. J. Greimas, a semiótica trata de um paradigma teórico e metodológico cuja intenção é estudar discursivamente a sociedade. A noção de texto como unidade de sentido está relacionada à natureza do objeto, ao recorte; é um corpus delimitado para o estudo semiótico (GREIMAS; COURTÉS, 2012, p. 503). Assim sendo, o contexto seria a reunião de textos (implícitos ou explícitos) que podem ser restabelecidos pela relação que eles mantêm entre si.

No Dicionário de Semiótica (GREIMAS; COURTÉS, 2012), os autores definem contexto como "o conjunto do texto que precede e/ou acompanha a unidade sintagmática considerada e do qual depende a significação" (ibid., p. 97). Em sua obra Semântica Estrutural (1976 [1966]), Algirdas J. Greimas inaugura a teoria relativa à Semiótica Discursiva, oferecendo ao analista ferramentas metodológicas para análise de textos. Para Greimas a noção de texto vai além de uma organização de palavras, frases e sentenças que podem ser compiladas em artigos, livros, compêndios, jornais e afins. Segundo o autor, o texto é definido pela sua organização interna e pelas determinações contextuais, podendo ser oral ou escrito (um romance de Machado de Assis, uma capa de jornal ou o discurso de um presidente falado a multidões), visual (um quadro de Monet) e sincrético. Essa última modalidade textual se dá quando há mais de uma linguagem expressa, a exemplo dos quadrinhos, do cinema e, não podemos esquecer, dos memes de internet.

\footnotetext{
${ }^{23}$ TAVARES, Flávia. Os memes da crise política. Época. Tempo. 11 de maio de 2016. Disponível em: https://epoca.globo.com/tempo/noticia/2016/05/os-memes-da-crise-politica.html. Acesso em 03 de outubro de 2019
} 
Para a Semiótica, todo texto possui uma estrutura interna. O percurso gerativo do sentido se apresenta como "uma sucessão de patamares cada um dos quais suscetível de receber uma descrição adequada que mostra como se produz e interpreta o sentido, num processo que vai do mais simples ao mais complexo" (FIORIN, 2016b, p. 20). A divisão desses patamares, estruturalmente organizados, propõe a análise do texto em três níveis distintos: nível fundamental, nível narrativo e nível discursivo.

Os memes que analisaremos semioticamente neste trabalho são, reiteramos, expressões textuais estáticas (sem-movimento) de natureza sincrética verbovisual cujo sentido pretendido pelo enunciador é cravado na imanência textual que se manifesta na junção do plano de conteúdo com o plano da expressão.

\subsection{Plano de conteúdo}

\subsubsection{Nível fundamental}

Neste primeiro nível do percurso gerativo elaborado por Greimas, buscamos pelas "categorias semânticas que estão na base da construção de um texto" (FIORIN, 2016b, p. 21). Uma categoria semântica é fundamentada pela sua diferença, como /vida/ x /morte/, /liberdade/ x /dominação/ ou /identidade/ x /alteridade/. As categorias, no entanto, não são arbitrariamente organizadas. Elas necessitam ter um traço, algo em comum entre os termos que as compõem, a fim de se estabelecer essa diferença (ibid., p. 22).

Os termos semânticos que se situam em polos opostos no interior de uma categoria possuem uma relação de contrariedade mútua. Nos discursos políticos é comum escutarmos "o Brasil não pode se tornar uma Venezuela", país este construído discursivamente como uma nação socialista e não democrática. Ora, essa oposição entre os dois termos socialismo e democracia não parece muito eficaz, uma vez que os termos categoriais não possuem uma relação de pressuposição recíproca. Só existe morte porque existe vida, logo, é lógico determinar a relação de contrariedade e reciprocidade que se mantém entre os dois termos /vida/ $\mathrm{x} / \mathrm{morte} /$. Apesar desse temor, visto nas propagandas eleitorais, de que o país possa ter o mesmo destino que a Venezuela chavista por ela fazer parte do regime socialista, o oposto semântico de democracia seria, contudo, a ditadura (FIORIN, 2016b, p. 22). 
Determinados os dois contrários, ao aplicarmos uma operação de negação entre eles, a exemplo de democracia e ditadura, teremos como resultado os termos contraditórios: não-democracia e não-ditadura.

Figura 8- Quadrado Semiótico

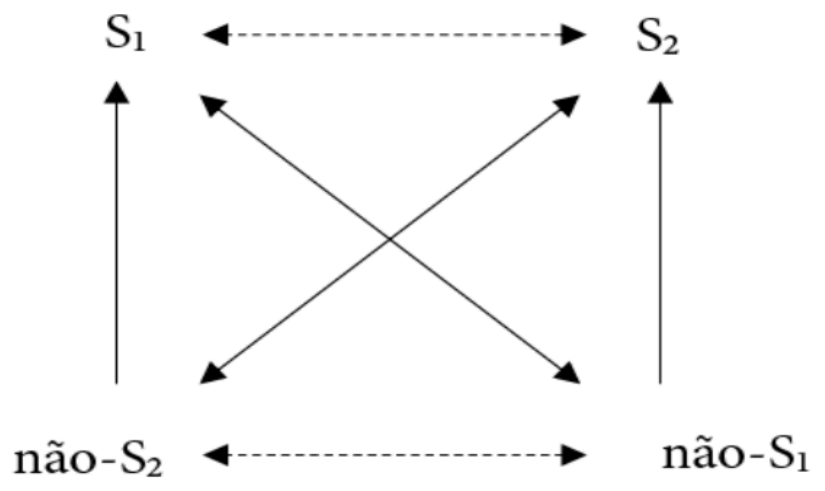

$\mathrm{S}_{1}-$ Democracia

$\mathrm{S}_{2}-$ Ditadura

$\underline{S}_{1}$ - Não-democracia

$\underline{\mathrm{S}}_{2}-$ Não-ditadura

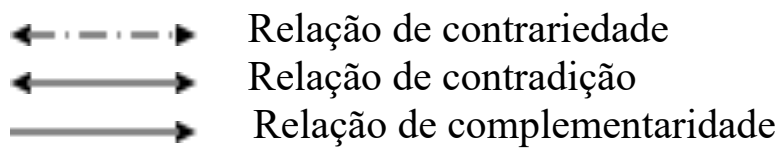

Fonte: Barros (2002). Adaptação nossa.

Definimos, desse modo, a sintaxe fundamental desta etapa da gênese do sentido que é produzida de forma relacional entre os termos, os quais são estabelecidos pela negação e pela asserção, construindo entre eles relações de contrariedade, contradição e complementaridade.

$\mathrm{Na}$ relação de complementaridade, a não-democracia $\left(\underline{\mathrm{S}}_{1}\right)$ implica em ditadura $\left(\mathrm{S}_{2}\right)$, assim como a não-ditadura $\left(\underline{\mathrm{S}}_{2}\right)$ implica em democracia $\left(\mathrm{S}_{1}\right)$, pois os termos se completam. Na contradição, por sua vez, os termos semânticos democracia e nãodemocracia se excluem mutuamente.

Na manifestação do segmento verbal do meme "Barbie e a Venezuela" (Figura 6), observa-se que existe uma perpetuação de determinados valores axiológicos do mundo percebido. A Venezuela, aqui retratada de maneira disforizada, indica os valores ditatoriais que a democracia brasileira rejeita. Trata-se de uma estratégia enunciativa que 
faz o leitor aderir às ideias propostas pelo texto através da manipulação, numa análise que pode ser feita a partir do nível narrativo.

Considerados de grande amplitude, os valores semânticos como /vida/ x /morte/ são universais semânticos. Entretanto, atribuir a esses valores universais valor do bem e do mal funda uma axiologia. Os valores axiológicos dizem respeito às forias. Segundo a doxa, o conjunto de juízo elaborado axiologicamente e compartilhado socialmente, a morte pode ser vista como valor negativo pois significa o fim da vida humana neste mundo. Fazendo a oposição dos termos semânticos /morte/ x /vida/, a morte é, para a doxa, disforizada, enquanto a vida, euforizada, é vista como valor positivo. No entanto, na obra de João Cabral de Melo Neto Morte e Vida Severina (1955), em várias passagens do poema a morte pode aparecer de maneira positiva, euforizada, pois livra o sertanejo da "sina", do fardo que é a tal "vida Severina" que leva.

Essa axiologia se instala no nível profundo do percurso gerativo da significação. Entre os sujeitos da enunciação, para acreditar na veracidade da maneira como o enunciador "axiologiza" o mundo narrado, estabelece-se um contrato de veridicção (BARROS, 2002). No nível narrativo, no qual ocorre a manipulação de um destinador que leva, através de um fazer persuasivo, um destinatário ao fazer interpretativo, há uma confiança pressuposta depositada no manipulador pelo manipulado para o cumprimento desse contrato. Segundo Barros: “A manipulação só será bem sucedida se o sistema de valores que está por detrás dela for compartilhado pelo manipulado" (2002, p. 39). A produção de memes conta, então, com essa bem sucedida manipulação.

\subsubsection{Nível Narrativo}

Neste segundo nível, procura-se investigar os sujeitos, suas ações, seus estados e suas transformações (bem como as manipulações). Idealizado a partir do legado teórico de Vladimir Propp sobre os contos maravilhosos russos, onde se encontram personagens como o herói, o rei e a princesa, a estrutura do nível narrativo se baseia no "esquema narrativo canônico" e compreende as fases da manipulação, competência, performance e sanção.

Antes de adentrarmos as fases supracitadas, nosso ponto de partida serão as definições de Fiorin (2016b) que fazem uma distinção entre narratividade e narração. Aquela é de característica comum a todo texto, enquanto esta se atribui apenas a uma determinada classe de textos (p. 27). Por narratividade entende-se uma sucessão de ações 
que engendram uma transformação do estado inicial para o estado final.

A narratividade, ainda de acordo com os estudos de Fiorin (2016b), difere da narração por ser um componente da análise do discurso que implica uma transformação dos estados e das ações dos actantes envolvidos, ao passo que a narração diz respeito a um tipo textual específico (p. 28).

Nessa instância do percurso gerativo ocorre a conversão das estruturas sintáticosemânticas profundas nas estruturas narrativas. Para Barros (2007, p. 16), a sintaxe narrativa seria como um "espetáculo que simula o fazer do homem que transforma o mundo". Para tanto, é importante descrever esse espetáculo, quem são os sujeitos envolvidos e quais são seus devidos papéis na cena espetacular. A sintaxe narrativa se faz valer de dois tipos de enunciados elementares: enunciados de estado e de fazer.

Nos enunciados de estado se estabelece uma relação de junção (disjunção ou conjunção) com o objeto (FIORIN, 2016b, p. 28); já os enunciados de fazer são os da transformação. Retomemos o meme "O PT quase destruiu minha vida" (Figura 4) para melhor elucidar essa questão. Na abstração narrativa, temos dois sujeitos actanciais: $\left(\mathrm{S}_{1}\right)$ e $\left(\mathrm{S}_{2}\right)$. A partir desta relação estabelecida entre os sujeitos, o que está implícito é que o $\left(S_{1}\right)$, entendido como sujeito destinador de valores, colocou $\left(S_{2}\right)$, destinatário, para entrar em conjunção com um objeto de valor disfórico, justificando a sanção "O PT destruiu a minha vida". No nível discursivo os sujeitos se transformam em atores de enunciado, ou seja, personagens. Assim como os objetos, esses papéis são instaurados pelas figuras actanciais.

Segundo Barros (2007, p. 17), os enunciados elementares (de estado e de fazer) da sintaxe narrativa caracterizam-se pelo caráter transitivo de dois actantes, objetos e sujeitos. Como define a autora

[...] a relação define os actantes; a relação transitiva entre sujeito e objeto dá-lhes existência, ou seja, o sujeito é o actante que se relaciona transitivamente com o objeto, o objeto aquele que mantém laços com o sujeito. Há duas diferentes relações ou funções transitivas, a junção e a transformação e, portanto, duas formas de enunciado elementar, que, no texto, estabelecem a distinção entre estado e transformação [...] (2007, p. 17, grifo da autora).

O Dicionário de Semiótica (2012) determina os actantes como possuidores de uma função sintática dentro do enunciado narrativo, de caráter puramente formal e livre de investimentos semânticos ou ideológicos (GREIMAS; COURTÉS, 2012, p. 21). Na concepção sintagmática do enunciado narrativo elementar, a função de que se ocupam os 
actantes é de sujeito e objeto e destinador, podendo este ser o manipulador ou o julgador, ou mesmo um antidestinador. Os papéis actanciais mudam de acordo com a posição (paradigma) que ocupam no decorrer da narrativa.

As estruturas actanciais se articulam como posições formais que permitem a gênese do sentido. Não importa se fazem parte de verbalizações projetadas do mundo real ou se são anteriores ao fazer linguístico (GREIMAS, 2014, p. 63), obedecem à lógica dada pelo percurso narrativo. Retomando nossa explicação anterior a respeito dos enunciados de estado, no qual ocorre a junção, o sujeito da narração faz o percurso da manipulação, em que ele é persuadido a entrar em conjunção ou disjunção com um determinado objeto de valor.

\subsubsection{Manipulação}

Greimas e Courtés explicam que a categoria da manipulação é caracterizada por uma ação sobre o objeto e outra do homem sobre outros homens, o que leva a duas modalidades, de "fazer-crer" e de "fazer-fazer" (2012, p. 300). Sendo assim, os autores afirmam que essa forma de atividade corresponde a uma estrutura modal factitiva (do fazer), sustentada por outra estrutura, dessa vez contratual (idem, p. 301). O destinadormanipulador tenta propor ao destinatário-manipulado um tipo de manipulação que este não será capaz de recusar, havendo então uma transformação da competência modal do destinador-manipulador que melhor faça valer o seu fazer-persuasivo. O destinatário, porém, pode recusar os valores, o que interrompe a realização dos programas narrativos subsequentes. Sem a manipulação bem sucedida a performance não se cumpre. O sujeito $\mathrm{S}_{2}$, que recebeu a manipulação do destinador, poderá criar outro programa narrativo para se opor ao primeiro.

Através do fazer-persuasivo do manipulador se estabelece uma relação fiduciária entre destinador e destinatário, fazendo este último ser condicionado a aderir aos valores por um fazer-interpretativo de sua parte. Segundo Greimas $(2014$, p. 122), a função última não é um dizer-verdadeiro, mas um exercício sobre o fazer-parecer-verdadeiro. $\mathrm{O}$ contrato de fidúcia é, por definição, um contrato baseado na confiança. O destinatário crê no destinador, crê no objeto, crê no discurso que lhe é apresentado.

Para o bom funcionamento do contrato fiduciário, o discurso é lido como verdadeiro pelo enunciatário (nível discursivo) se corresponder ao que ele já espera a partir de sua própria axiologia, pelo simulacro da verdade, da imagem que ele faz do 
enunciador (GREIMAS, 2014, p. 122). Greimas assim define o contrato de veridicção:

[...] o discurso é esse lugar frágil onde se inscrevem e se leem a verdade e a falsidade, a mentira e o segredo; modos de veridicção resultantes da dupla contribuição do enunciador e do enunciatário; suas diferentes posições não se estabelecem senão na forma de um equilíbrio mais ou menos estável que provém de um acordo implícito entre os actantes da estrutura da comunicação. É esse acordo tácito que é designado pelo nome de contrato de veridiç̧ão" (GREIMAS, 2014, p. 117, grifo do autor).

Uma das problematizações teóricas que desenvolvemos ao longo das análises diz respeito às modalidades veridictórias. Greimas e Courtés (2012, p. 532-533) sintetizam a categoria da veridicção por meio do exame do parecer do ser do sentido. Apresentam, para isso, este quadrado semiótico:

Figura 9 - Quadrado Semiótico da veridicção.

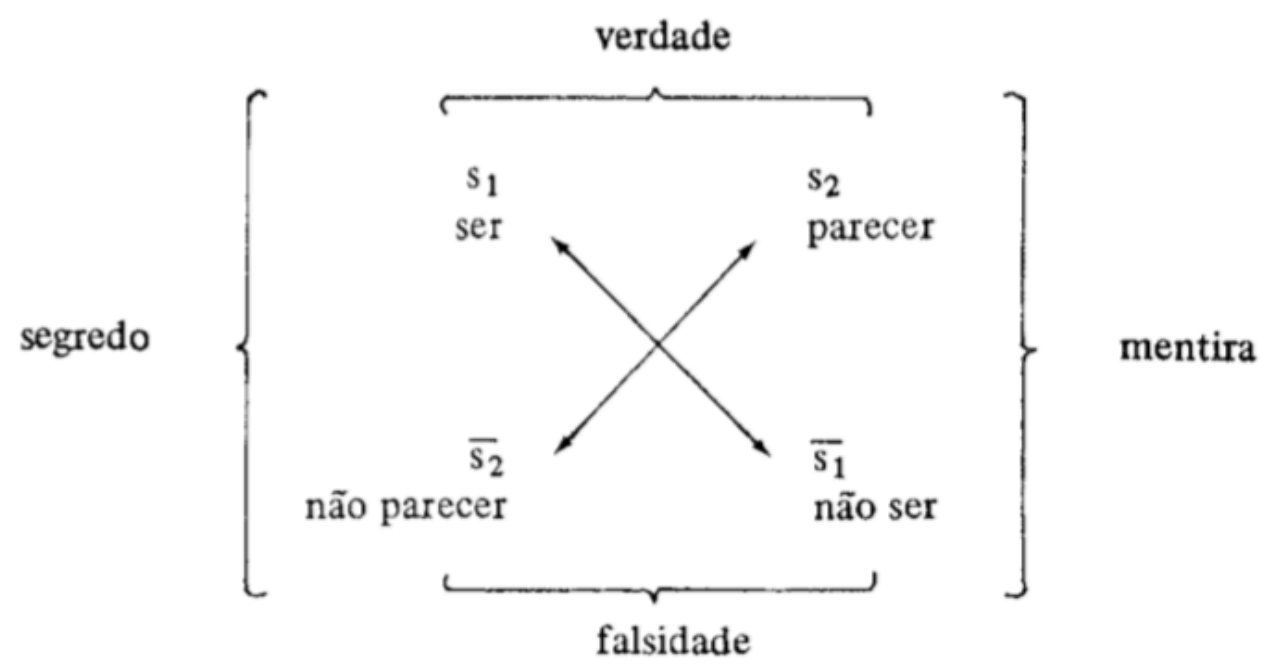

Fonte: Greimas; Courtés (2012).

Uma das hipóteses para pesquisar a estrutura composicional, a temática e o estilo dos memes vinculados à dimensão das notícias é de que estas, mais do que os memes, apresentam uma maior dependência em relação ao que é verdade, mentira e falsidade. Pretendemos, ao longo de nossa dissertação, descrever mecanismos da construção do sentido dos memes políticos na relação estabelecida com os fatos noticiosos, pela investigação, na sintaxe narrativa, das operações de persuasão de manipulação envolvidas nos textos chamados de memes de internet. Para tal feito, a gramática narrativa elaborou 
uma tipologia de quatro modos distintos de manipulação: tentação, sedução, provocação e intimidação.

Nesta primeira forma de manipulação, a tentação, o destinador tenta subornar o destinatário com um objeto de valor positivo. Quer dizer, ao sujeito é oferecido algo que ele almeja do universo cognitivo. A persuasão do discurso político tem em vista um destinatário-eleitor previsto e se serve da tentação como estratégia para anunciar um bem desejável comum. Em um dos debates presidenciais das eleições de 2018, o candidato Ciro Gomes fez a promessa de cancelar a dívida ${ }^{24}$ de todos os eleitores caso saísse vitorioso no pleito que acabou elegendo o presidente Jair Bolsonaro. Em seu discurso, após citar que no Brasil havia 63 milhões de cidadãos endividados, com o "nome sujo", o então deputado declarou "Pode ficar tranquilo; [se você me eleger] eu vou tirar seu nome do SPC" 25 . Afirma-se que o presidenciável-destinador utilizou a tentação que induz o eleitor-destinatário a votar nele oferecendo a liquidação das dívidas em troca, promessa que apela para um grande público, dado o grande número de brasileiros insolventes. A manipulação deve ter sido bem sucedida para alguns eleitores, mas não o suficiente para garantir a eleição do candidato.

Na sedução, o segundo tipo de manipulação, o manipulador exalta qualidades e virtudes do manipulado. O destinador convence o destinatário pelas características que se supõe que este tenha, sendo elas verdadeiras ou não. A sedução é feita através de uma adulação onde valores como atributos e conduta ética do destinatário são reforçados em prol do jogo persuasivo.

Já na provocação, o terceiro modo, o destinatário age para mudar a ideia que o destinador tem sobre ele. Neste modo de persuasão, o destinador-manipulador, ao invés de exaltar os bons predicados do destinatário, como acontece na sedução, denigre-o de certa forma. Cabe ao destinatário, pela sua competência adquirida e mais tarde pela ação, provar o equívoco do destinador. Um exemplo de manipulação pela provocação dado pelo professor Fiorin (2016b, p. 30) é "pus essa comida no seu prato, mas eu sei que, como você é pequeno, não consegue comer o que está aí".

No quarto e último modo, a intimidação, ao invés de se valer de valores positivos,

\footnotetext{
${ }^{24}$ MELO, Debora. A proposta de Ciro Gomes para limpar o nome dos brasileiros no SPC é viável? HuffPost Brasil. 15 de agosto de 2018. Disponível em: https://www.huffpostbrasil.com/entry/a-proposta-de-cirogomes-para-limpar-o-nome-dos-brasileiros-no-spc-e-viavel br 5c33872fe4b0f65f9273ae98. Acesso em 19 de janeiro de 2020.

${ }^{25}$ Ciro discute com Bolsonaro como retirar a população do SPC. Vídeo do canal Band Jornalismo no YouTube. 09 de agosto de 2018. Disponível em: https://www.youtube.com/watch?v=S-1-VtJ41Ko. Acesso em 19 de janeiro de 2020.
} 
fala-se agora de valores negativos, de uma conduta que é aconselhável não ter, ou melhor dizendo, oferecendo valores que não sejam do desejo do destinatário. $\mathrm{O}$ contrato estabelecido também pode operar por uma privação de valores positivos, levando o destinatário a agir em defesa destes.

Na tentação e na intimidação, os valores ofertados pelo destinatário são eufóricos. Já no que diz respeito aos outros dois modos de manipulação, a sedução e a provocação, há uma construção de uma identidade que se projeta de maneira positiva, na sedução, e negativa, na provocação.

Um meme que apareceu ainda durante a corrida presidencial em 2018 a respeito do ex-prefeito de São Paulo, ex-ministro da educação e concorrente ao planalto Fernando Haddad (PT), dizia que o candidato não deveria ganhar votos durante a disputa, pois ele seria o responsável pela invenção da "mamadeira de piroca" e do "kit gay", ambos destinados ao público infantil. No sintagma verbal, visto superposto à parte visual e encontrado na parte superior do texto meme, lê-se "se você defende as crianças, não vote nele".

Figura 10 - Meme "Haddad criador"

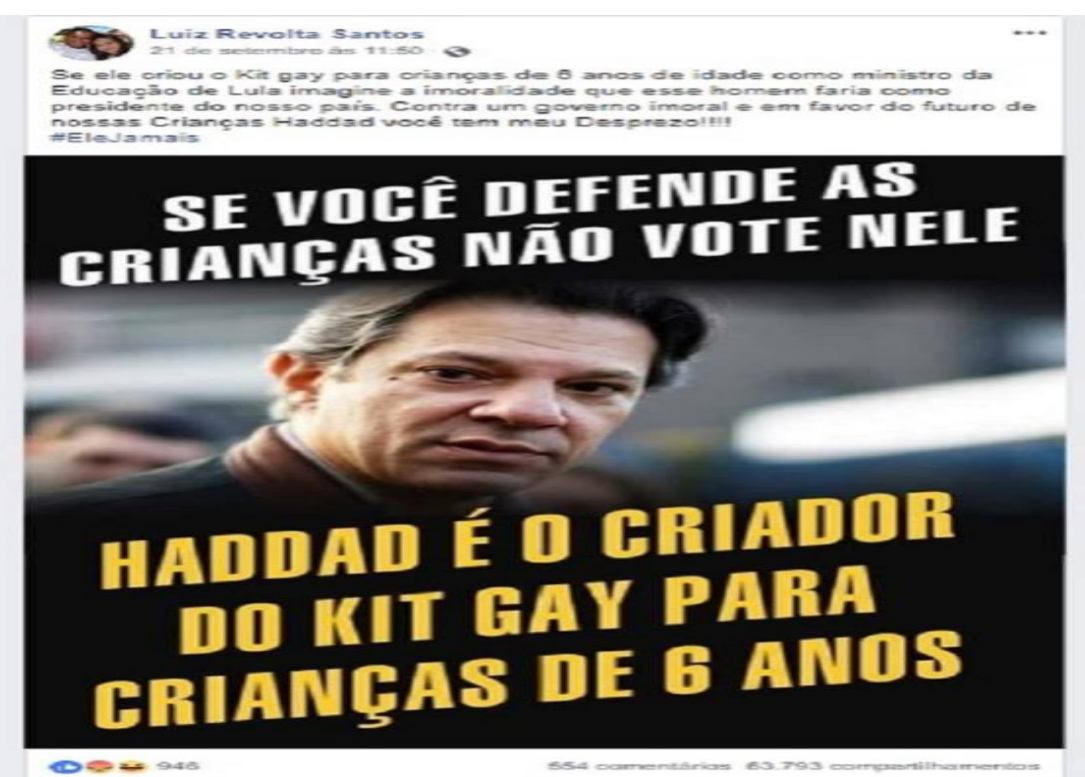

Fonte: https://imagens.brasil.elpais.com/resizer/8CSvNxJ0mSfDTueziN2yYKaj YI=/1500x0/arcanglerfish-eu-central-1-prod-prisa.s3.amazonaws.com/public/OSYU7PAP5IKC6PMSPWD4HIIYGI.jpg. Acesso em 20 de janeiro de 2020.

No texto meme (figura 10), o destinatário tem, através do seu voto, o poder e, logo, o dever moral de não eleger o candidato petista, a fim de evitar que suas ideias, disforizadas pelo manipulador-destinador e compartilhadas em comunhão pelo 
manipulado-destinatário, não cheguem a cabo. Considera-se, assim, esta uma manipulação por provocação.

O segmento visual deve ser levado em conta no momento da manipulação por intimidação ocorrida no nível narrativo. A foto do candidato, no plano do conteúdo, serve para o leitor lembrar-se desse nome e dessa figura e não votar nele. Falaremos sobre o plano da expressão no ponto deste capítulo dedicado à enunciação sincrética.

\subsubsection{Competência e performance}

Caracteriza-se por competência o programa de aquisição de valores modais que pressupõe ter o enunciatário para realização da performance. O sujeito actancial passa agora a ocupar a posição de actante funcional "definido por um conjunto variável de papéis actanciais". Esse actante é determinado por um estado afetado pelo "programa de competência e a de ser o sujeito realizador da performance ou, ao menos, competente para realizá-la” (BARROS, 2007, p. 27).

A atribuição de competência modal é a manipulação propriamente dita (BARROS, 2007, p. 28). Na narrativa há dois tipos diferentes de objetos: os objetos de valor e os objetos modais (FIORIN, 2016b, p. 36-37). Aqueles são com os quais se entra em conjunção ou disjunção; estes são o querer, o dever, o saber e o poder, competências atribuídas ao destinador. Nessa fase da manipulação, o destinador atribui valores modais ao destinatário do "querer- fazer", do "dever-fazer", do "saber-fazer" e do "poder-fazer".

Para deixar mais claras tais definições, podemos sintetizar as competências modais e a tipologia da manipulação da seguinte forma: no exercício da persuasão por intimidação e tentação, apela-se para a modalidade do saber do destinatário. Na sedução e na provocação, pelo poder. Diana Barros (2007) propõe o quadro abaixo, que melhor resume nossas explicações:

Figura 11 - Tipos de manipulação

\begin{tabular}{|l|l|l|}
\hline & $\begin{array}{l}\text { Competências do } \\
\text { destinador-manipulador }\end{array}$ & $\begin{array}{l}\text { Alteração na } \\
\text { competência do } \\
\text { destinatário }\end{array}$ \\
\hline PROVOCAÇÃO & $\begin{array}{l}\text { SABER (imagem negativa } \\
\text { do destinatário) }\end{array}$ & DEVER-FAZER \\
\hline SEDUÇÃO & SABER (imagem positiva & QUERER-FAZER \\
\hline
\end{tabular}




\begin{tabular}{|l|l|l|}
\hline & do destinatário) & \\
\hline INTIMIDAÇÃO & $\begin{array}{l}\text { PODER (valores } \\
\text { negativos) }\end{array}$ & DEVER-FAZER \\
\hline TENTAÇÃO & PODER (valores positivos) & QUERER-FAZER \\
\hline
\end{tabular}

Fonte: BARROS (2007). Adaptação nossa.

\subsubsection{Sanção}

Uma vez cumprida a performance, esta é finalmente submetida a uma sanção avaliadora (SARAIVA; LEITE, 2017, p. 52). Nesta parte do percurso, o sujeito irá ser recompensado pela sua performance ou receberá por ela uma punição. É com a sanção que se encerra o percurso canônico da semiótica standard.

Nas histórias de conto de fadas, o herói que parte em busca do seu objeto de valor, que é a princesa do castelo, após ter realizado a performance salvando-a do aprisionamento e das mãos do antissujeito que a mantinha reclusa, será finalmente recompensado pelo rei, o seu destinador-manipulador, como lhe fora prometido: sua sanção positiva lhe garantirá a mão da bela princesa.

Os memes, contudo, não apresentam personagens de papéis actanciais tão bem definidos, nem possuem uma narrativa como nos contos maravilhosos, mas apresentam uma sanção que se destaca na gramática semio-narrativa. Diana Barros (2015) nos indica, a respeito da complexidade que são os discursos na web, que os discursos online são, em grande parte, discursos sancionadores.

Charles Baudelaire (2007) argumenta que o riso é um ato satânico e egoísta. Nunca se ri de si próprio, mas sempre de outro, pois pressupõe-se que nós temos uma superioridade garantida em relação àquele que é o motivo de nossa gargalhada. É sempre o "outro", nunca o "eu”. Os memes, por serem textos típicos da internet, humorísticos em sua maioria, sancionam negativamente a sua vítima na chacota virtual e, por isso, cabe a ela a punição do riso.

Henri Bergson (2018) diz que o riso é a sanção do que é avaliado como um sintoma social que deveria ser corrigido no sujeito. $O$ cômico não busca nem a 
compreensão nem o diálogo (BERGSON, 2018). Logo, por ser considerado como algo superior, o riso atenua as nossas paixões de não-querer-ser, não-dever-ser e poder-nãoser, tornando-as, no discurso memético, menos intensas.

A Semiótica Discursiva tem se preocupado com aquilo que o texto faz conhecer, faz fazer (esta, a modalidade fática), faz crer, e com o sensível, em contraposição a uma análise apenas baseada no inteligível. Em 1993, Greimas e Fontanille começam a pensar em uma semiótica das paixões, colocando o sujeito actancial não apenas através de uma programação do sujeito virtualizado até o realizado, princípio de continuidade, mas como o sujeito que sente o mundo a sua volta, o que abriu espaço para a formulação das relações tensivas subjacentes aos estados passionais. Abordaremos o ponto de vista tensivo semiótico em detalhes mais adiante no Capítulo 3.

Retomemos o exemplo do meme sobre o candidato do PT Fernando Haddad (Figura 10). A sanção aplicada ao destinatário, manipulado por provocação, por não ter a performance de votar em quem propôs o "kit gay", é a recompensa de não ter no governo um estadista que queira incutir a cultura da homossexualidade nas crianças brasileiras que "logicamente ainda não tiveram o despertar sexual".

Lembramos que, para Greimas (2014), pelo contrato de veridicção, o discurso não precisa necessariamente ser verdadeiro, mas apenas ter a verdade na sua aparência. Para o autor (ibid., p. 109) "[...] já não se supõe que o sujeito da enunciação produza um discurso verdadeiro, mas um discurso que produza um efeito de "verdade"".

No meme recém citado, o tema da proteção à infância indefesa diante da perversidade de um político se escora na concretude discursiva da manipulação. A enunciação faz o leitor crer e faz o leitor fazer, nesse caso, ser contra o candidato incorporado.

Os temas e as figuras são observados pela semântica discursiva no último patamar do percurso gerativo e, junto com a instalação das categorias de pessoa, espaço e tempo, conferem no nível discursivo maior concretude aos níveis precedentes.

\subsubsection{Nível Discursivo}

\subsubsection{Sintaxe discursiva - Categorias de pessoa, tempo e espaço}

Antes de falarmos de autor e leitor, estes são vistos pela semiótica como componente do enunciado dos textos meméticos, criado pelo enunciador e pelo 
enunciatário. Estes últimos são observados a partir das instâncias da enunciação (FIORIN, 2016a).

Se a enunciação é o ato de produzir enunciados, o enunciado seria então a materialidade da enunciação. Ele possui "elementos que remetem à instância da enunciação: de um lado estão os pronomes pessoais e possessivos, os adjetivos e advérbios apreciativos, os dêiticos espaciais, temporais e etc. [...], e, de outro lado, os verbos performativos" (GREIMAS; COURTÉS, 2012, p. 169).

As categorias de pessoa, tempo e espaço são as marcas, as instâncias da enunciação as quais “[...] só podem ser interpretadas se reportamos ao único ato da enunciação que produziu o enunciado que figuram” (FIORIN, 2016a, p. 47). Essas marcas são dadas pelos mecanismos de debreagens. Esses mecanismos podem ser de dois tipos: debreagem enunciativa e enunciva. Na primeira há a projeção do eu, do aqui e do agora (ego, hic et nunc) instalados no enunciado. Na segunda, projetam-se o ele, o então e o alhures. As debreagens são responsáveis por criar efeitos de subjetividade (se enunciativas) e objetividade (as enuncivas). Nota-se que, nesses casos, ocorre um simulacro de enunciação, o que faz produzir os efeitos que criam aproximação ou distanciamento com o texto.

Para darmos um exemplo, numa frase que circulou como bordão de campanha política na internet contra o impeachment da ex-presidente Dilma Rousseff, "Fora Temer", não há a instauração explícita de um "eu”, debreagem enunciativa. O enunciador da frase não diz "eu penso que é melhor que temer caia fora da presidência", mas há um enunciador implícito que afirma a injustiça do processo e expressa um desejo de afastar Michel Temer do planalto. No caso "eu afirmo que Michel Temer deveria abdicar do seu cargo", a enunciação se projeta no enunciado e temos, assim, uma debreagem enunciativa de primeiro grau. Fora Temer é debreagem enunciva, pois o eu não está explicitado. Há paralelamente um verbo implícito, “cai”, em cai fora. O verbo está marcado no imperativo e apresenta como dominante a função conativa. Cumpre-se o ato performativo de querer tirar o presidente interino do cargo que ocupava. 


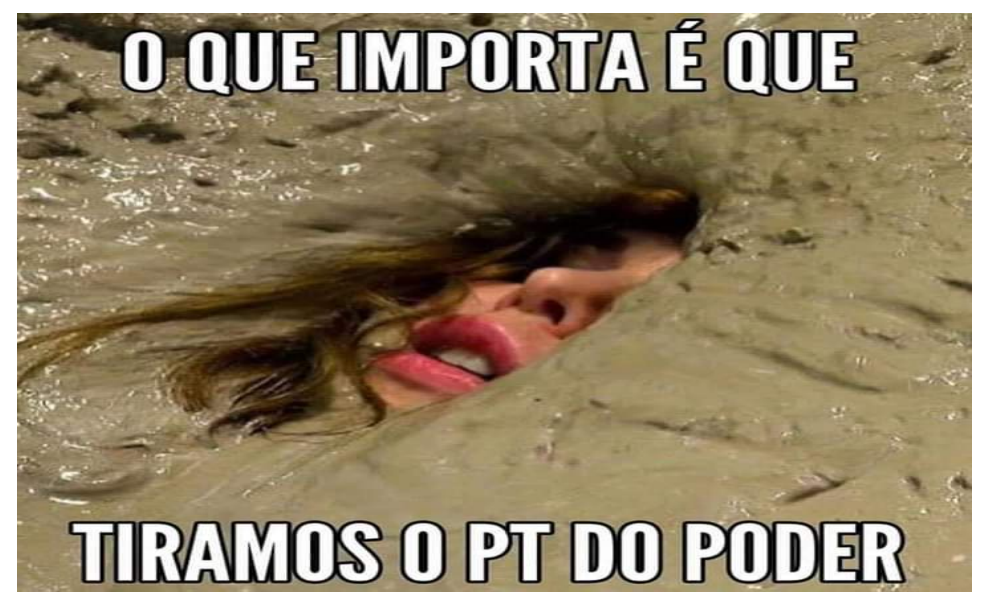

Fonte: https://pbs.twimg.com/media/D5FHr5MWwAEQ9rl.jpg. Acesso em 20 de janeiro de 2020.

No meme acima (Figura 12), analisando apenas seu segmento verbal, lê-se "O importante mesmo é que tiramos o PT”. O “nós”, primeira pessoa do plural, é a marca de subjetividade do enunciado, portanto uma debreagem enunciativa. A partir do pronome pessoal, temos a instauração do sujeito da enunciação (GREIMAS; COURTÉS, 2012, p. 167). Reiterando o que dissemos anteriormente, ao se dizer um "eu" (enunciador-autor), se pressupõe um " $t u$ " (enunciatário-leitor). Tanto o autor da mensagem quanto o leitor para quem a mesma se endereça não são de carne e osso, porém uma imagem do autor e do leitor implícitos construída no interior do texto (FIORIN, 2004, p. 70).

Outra forma de se instalar as categorias de pessoa, tempo e espaço é pelas embreagens, como explicitado por Fiorin (2016a). Ao contrário das debreagens, as embreagens são um retorno à enunciação na qual se neutralizam as marcas referenciais relativas às instâncias enunciativas, marcadas nas categorias de pessoa, tempo e espaço. Nelas, "finge-se" um retorno de formas já debreadas, criando uma ilusão de identificação com a instância da enunciação (FIORIN, 2016a, p. 41).

Fiorin (2004) explica que o "eu" e o "tu" são actantes da enunciação pois eles ocupam posições sintáticas dentro da cena enunciativa: "quem fala" e "com quem se fala". As debreagens (e as embreagens), componentes da sintaxe discursiva do percurso gerativo, instalam a pessoa no discurso. A pessoa, quando tematizada e figurativizada, converte-se então em ator do discurso (FIORIN, 2016a, p. 51).

Quanto à figura actorial, o ator pode ser um sujeito do enunciado, que fala em debreagem enunciativa de segundo grau (um interlocutor), muito comum nos memes. $\mathrm{O}$ ator pode ser o sujeito enunciador que se apresenta como ator da enunciação. $\mathrm{O}$ ator da 
enunciação desempenha papéis temáticos e papéis actanciais próprios à manipulação enunciativa.

\subsubsection{Semântica discursiva - Temas e figuras}

$\mathrm{Na}$ semântica discursiva, temos os temas e as figuras que vão recobrir semanticamente o texto, dando a ele uma aparência concreta que espelha o mundo enunciado. Os temas e figuras nada mais são que "enriquecimentos semânticos" dos elementos narrativos do nível anterior (BARROS, 2007). As figuras remetem ao mundo natural construído no (e através do) texto. Já os temas são categorias que organizam, categorizam, ordenam os elementos do mundo natural que é narrado (FIORIN, 2016b, p. 91).

Diana Barros (2002, p. 109) define a semântica discursiva como responsável por criar efeitos de realidade que auxiliam na operação de persuadir e convencer. A imagem retratada pelo enunciador dos memes de internet emula um fazer-crer que a faça semelhante ao mundo real, e, a partir daí, confere veracidade ao discurso (p. 117-118).

Um meme que retrate a figura da ex-presidente Dilma Rousseff pode ter como tema o golpe, o feminismo, o machismo na política, entre outros tantos possíveis. Os temas são termos abstratos que se complementam nas figuras responsáveis por lhes dar maior concretude. Essa é a distinção entre os textos temáticos e os textos figurativos: enquanto os temáticos nos explicam o mundo, os figurativos criam simulacros do mundo (FIORIN, 1995, p. 171). No texto temático prevalecem os efeitos de sentido da enunciação e não da realidade instalada no percurso temático, uma vez que a realidade também é um efeito produzido pelo enunciador. A verdade discursiva provém de fato das marcas da enunciação, da presença ou da ausência enunciativa, que conferem a ilusão de verdade do enunciador ao enunciatário. As figuras apontam para a questão histórica dos discursos, seja a presidente, o prefeito ou o ministro, todos eles atores do enunciado figurativizados; porém, mais que meras figuras, eles ressaltam emoções do sujeito que enuncia, dando espaço ao julgamento moral do enunciador. Pela explicação de Discini

A figurativização dos temas aponta para convenções sociais que materializam historicamente o discurso. Por sua vez, os temas que, abstratos, são figurativizados, suportam os papéis temáticos, que os condensam no circuito de um sujeito-ator. Esse ator, adensado semanticamente, figurativiza-se e assim vai compondo sua imagem. Figurativizado, o ator do enunciado resulta de uma imagem, que, conceitual, está vinculada a interpretações do mundo feitas pelo 
enunciador. A mesma imagem também diz respeito às tensões e às emoções do sujeito que enuncia. A figura do ator do enunciado, conforme o crivo enunciativo viabilizado pelo narrador de qualquer tipo de texto, não se basta, portanto, à mera concretização dos temas. Ela convoca outros investimentos enunciativos, semânticos e tensivos, o que encerra julgamento moral e percepção (2018a, p. 310).

Os temas e as figuras retratados já possuem agregado um valor positivo ou negativo atribuído pelo enunciador. $\mathrm{O}$ ator do enunciado é o personagem que figurativiza o tema do enunciado. Os investimentos axiológicos e tensivos depositados no ator do enunciado orientam ideologicamente os sujeitos da enunciação, o "eu" e o "tu", enunciador e enunciatário, respectivamente.

\subsubsection{O ator da enunciação memética}

A concretização dessa estrutura actancial do "eu" e do " $t u$ " nada mais é senão “[...] uma estrutura topológica, já que os diferentes atores do discurso são constituídos como uma rede de lugares que, vazios por natureza, são lugares de manifestação das estruturas narrativas e discursivas" (GREIMAS; COURTÉS, 2012, p. 45). Quer dizer, eles cumprem uma função sintática antes de receber investimentos semânticos. Já o ator da enunciação, parafraseando Greimas e Courtés, define-se como "um Baudelaire” pela totalidade de seus discursos (2012, p. 46). Como bem definiu Fiorin

Quando falamos em eu e $t u$, falamos em actantes da enunciação, ou seja, em posições dentro da cena enunciativa, aquele que fala e aquele com quem se fala. No entanto, nos diferentes textos, essas posições são concretizadas e esses actantes tornam-se atores da enunciação (2004, p. 70).

O ator da enunciação não é só uma instância pressuposta pelo enunciado, um "eu" e um " $t u$ ", mas uma imagem concreta que o discurso constrói (FIORIN, 2004, p. 71). Os sujeitos actanciais da estrutura semio-narrativa, destinador-manipulador e destinatário, ganham agora corpo, voz e caráter quando são semântica e sintaticamente revestidos, remetendo à imagem enunciativa do enunciador (DISCINI, 2018a, p. 311).

Ao partirmos do princípio da enunciação pela Semiótica Discursiva, é certo afirmar que todo enunciado diz algo para alguém. $\mathrm{O}$ enunciador dos enunciados online, que são os memes, produz seu discurso a ser partilhado por um enunciatário que vai por ele se interessar: seja dando uma apreciação em forma de "curtida" pelas redes sociais, compartilhando ou modificando o texto original ao seu modo. Para tal, o enunciador do 
meme lança mão de estratégias: na escolha da imagem visual, na formulação lexical das frases verbais e no tom satírico que imprime (criando seu éthos), tudo em função desse enunciatário pressuposto que vai expandir o número de visualizações do enunciado verbovisual.

O ator da enunciação dos memes tem um corpo discursivo, uma voz e um caráter - por isso possui um éthos. É um enunciador crítico social sobretudo, e essa crítica é feita por uma voz que se atribui a um narrador que, para transformar-se em ator, é tematizado como produtor dos memes, igualmente pelo modo de valorizar, axiológica e ideologicamente, o mundo - o que afirmamos a partir da noção de narrador trazida por Fiorin (2016a). Esse ator também é aspectualizado - costuma ter um aspecto incoativo, como ponto de partida da postagem, o que evolui para um aspecto terminativo: o "memista" não deixa dúvida. O enunciador do meme é um satírico que "destrói" discursivamente o objeto de sua sátira.

Esses enunciados verbovisuais, os memes, têm como destino um público-leitor, conforme afirmamos previamente. Logo, cada meme possui um enunciatário certo que também é percebido, em ato, como ator da enunciação. De acordo com Discini (2018b, p. 119), "o narratário partilha com o narrador as condições narrativas que fazem emergir os papéis temáticos do ator. Por isso, o enunciatário também se afirma como ator da enunciação".

O éthos do enunciador transparece nos modos, segundo Discini

[...] de valorizar temas, figuras e, entre eles, a figura do ator do enunciado. Tal valorização concerne o posicionamento ideológico do enunciador como presença cravada na polêmica constitutiva das relações sociais e interdiscursivas (DISCINI, 2018a, p. 311-312).

Ora, o ator da enunciação do meme, para se compor como motor do estilo dos memes, implica uma recorrência, um modo de dizer que remete ao modo de ser e se posicionar no mundo - o que resulta em recorrência de papéis temáticos (de julgamento) e de papéis patêmicos (da sensibilidade ou do sentir o mundo narrado). Greimas e Courtés definem o papel temático como

A representação, sob forma actancial, de um tema ou de percurso temático (o percurso 'pescar', por exemplo, pode ser condensado ou resumido pelo papel 'pescador'). $O$ papel temático é obtido simultaneamente por: a) redução de uma configuração discursiva a um único percurso figurativo (realizado ou realizável no discurso) e, além disso, a um agente competente que virtualmente o subsume; e b) 
determinação de sua posição no percurso do ator, posição que permite fixar para o papel temático uma isotopia precisa (entre todas aquelas em que ele pode virtualmente inscrever-se). A conjunção de papéis actanciais com papéis temáticos define o ator (GREIMAS; COURTÉS, 2012, p. 496).

Enfatizamos que a imagem desse éthos do ator da enunciação é construída na enunciação e não aparece de maneira explícita no enunciado. Para Fiorin, trata-se da construção do éthos do ator:

Quando um jovem diz eu sou contra as normas de nossa ordem social, está explicitando uma imagem sua no enunciado. Isso não serve de prova, não leva à construção do éthos. $\mathrm{O}$ caráter de pessoa rebelde constrói-se na maneira como se veste, como age, como fala, que lexemas escolhe etc. À medida que ela vai construindo o texto de sua vida, vai dizendo estou contra a atual ordem social. A enunciação não é da ordem do inefável. Por conseguinte, o éthos explicita-se na enunciação enunciada, ou seja, nas marcas da enunciação deixadas no enunciado (FIORIN, 2007, p. 29, grifo do autor).

Nos memes de temática política veremos como essa imagem do ator da enunciação não apenas se diz ser "contra a atual ordem social", mas também demonstra sê-lo pelas marcas por ele deixadas na enunciação, instaladas nas categorias da actorialização, espacialização e temporalização, pela escolha do léxico, pela postura que assume, pela imagem que ele passa ao seu enunciatário.

Esse éthos do enunciador dos memes de que falamos não é uma imagem real do seu autor. Ele seria um autor implícito, um autor discursivo (FIORIN, 2007). A imagem do leitor, aquele que recebe o meme pelas redes de relacionamento social, também é uma imagem estabelecida no texto e pelo texto. $\mathrm{O}$ " $e u$ " do qual falamos não é o "eu" real do discurso, mas apenas uma instância imposta pela enunciação.

Se num meme temos a presença de um dêitico na primeira pessoa do singular, esse "eu" remete ao ator do enunciado. O ator é sempre uma concretização temáticofigurativa do sujeito actancial. Pode ser o prefeito da cidade ou o presidente do Brasil, por exemplo, no caso dos memes políticos. Mas é claro que não foram os próprios que tomaram tempo de suas compromissadas agendas na produção de memes autobiográficos. Pelo meme podemos ter uma ideia do caráter do seu enunciador. Já o ator da enunciação, como afirmamos anteriormente, é visto por uma totalidade discursiva. Numa sequência memética temática e figurativa temos um ator da enunciação, um éthos, que a priori possui caráter, um tom e um corpo, segundo a concepção de éthos de Maingueneau (2013). 
Da totalidade dos memes selecionados para esta dissertação depreende-se o ator da enunciação dos memes políticos com um corpo cravado na intertextualidade midiática, com uma voz crítica, voltada para determinado alvo no modo de uma sátira.

\subsection{Plano de expressão - A enunciação sincrética}

Segundo Viktor Chagas (2018, p. 8), os memes são produzidos e compartilhados por um "coletivo apaixonado". Por essa razão, o autor defende que eles não são aprioristicamente desenhados para uma audiência em massa, pois surgem sempre de maneira espontânea. No entanto, ao considerarmos que em todo enunciado algo é dito para alguém sempre na pressuposição desse enunciatário-leitor como coprodutor do sentido, aí já está um princípio de organização, que desmonta a tese de "espontaneísmo" dos memes apontada por Chagas. Os memes parecem espontâneos, mas não são; logo, são espontâneos no modo da mentira - ou do segredo -, são calculados, mas não o parecem ser. As interações online que deles emergem despertam uma forma de fazerpolítico no qual fazem prevalecer a orientação axiológica, o contrato de fidúcia, a manipulação por parte do destinador e o reconhecimento ideológico entre enunciador e enunciatário.

As imagens "memoráveis" do segmento visual do meme resgatam na memória algum fato ocorrido, quer dizer: as figuras e os temas invocados na imagem visual do texto são de conhecimento comum. Estes, apoiados pela parte verbal, podem causar no enunciatário do texto meme paixões de imediato, como repulsa, desejo, anseio, raiva e alívio.

Nas redes sociais, lugar de circulação dos textos meméticos, os memes ocorrem num concorrido espaço virtual por onde também circulam vídeos, notícias, mensagens de amigos, fotos, enfim, eles acabam sendo sobreviventes de um darwinismo às avessas na disputa pela atenção do internauta. Por esse motivo, a imagem tem que capturar seu enunciatário, lançando mão de estratégias enunciativas para surtir tal efeito.

A análise dos memes políticos não deve se ater apenas a uma gramática verbal, uma vez que as imagens, como defende Chagas (2018), remetem a situações e personagens da política brasileira, atores do enunciado, sem que nos seja exigido grande conhecimento prévio, visto que retratam assuntos recorrentes e noticiados pelos veículos de imprensa. Levando em conta que texto e imagem, ou melhor, segmento verbal e segmento visual (texto sincrético) fazem parte de um todo de significação, seria 
infrutífero fazer uma análise que privilegiasse apenas um dos segmentos em detrimento do outro.

No primeiro tomo do Dicionário de Semiótica (2012), Greimas e Courtés tomam por semióticas sincréticas aquelas que

[...] como a ópera e o cinema - acionam várias linguagens de manifestação; da mesma forma, a comunicação verbal não somente do tipo linguístico: inclui igualmente elementos paralinguísticos (como a gestualidade ou a proxêmica), sociolinguísticos, etc... (GREIMAS; COURTÉS, 2012, p. 467).

Partiremos do estudo de Floch (1986, p. 217-219) em que o semioticista conceitua as semióticas sincréticas. Em especial, contemplaremos nas análises esta afirmação do autor, a qual diz respeito às estratégias sincréticas concernentes a um único enunciador:

No caso dos procedimentos de sincretização, rejeitar-se-á a ideia de que, para haver um enunciado sincrético, há um enunciado verbal, uma enunciação gestual, uma enunciação visual... O uso de uma pluralidade de linguagens de manifestação para constituir um texto sincrético, em nossa opinião, faz parte de uma estratégia de comunicação sincrética global que "administra", se quisermos, o conteúdo discursivo resultante da textualização, e escolhe "investir" a linearidade do texto; em alguns casos, os procedimentos de sincretização podem revelar verdadeiras sinestesias. Essa estratégia sincrética revela a competência discursiva de um único enunciador, mesmo que este se actorialize das mais diferentes formas ${ }^{26}$ (FLOCH, 1986, p. 217-219).

O meme tem como princípio mecanismos de construção de sentido muito semelhantes à paródia, ao passo que ele retoma um texto-base e o subverte. Porém, isso é feito de modo próprio, uma vez que se trata de gênero textual midiático composto por duas linguagens de manifestação: a verbal e a visual. Ele é, pois, um texto sincrético, que pede uma enunciação sincrética (FLOCH, 1986). Na mistura de imagem e verbo que o compõe, há nas figuras compartilhadas algo de sensível e de inteligível que facilita a adesão e difusão desses memes, tomando para nós o que pensa Zilberberg (2011) sobre a noção de sensível e de inteligível.

\footnotetext{
${ }^{26}$ Do original "Pour ce qui est des procédures de syncrétisation, on rejettera tout d'abord l'idée que, pour tel énoncé syncrétique, il y ait une énonciation verbale, une énonciation gestuelle, une énonciation visuelle... Le recours à une pluralité des langages de manifestation pour constituer un texte syncrétique relève selon nous d'une stratégie, globale, de communication syncrétique qui "gère", si l'on veut, le contenu discursif résultant de la textualisation, et choisit d'“investir" la linéarité du texte; dans certains cas, les procédures de syncrétisation peuvent relever des véritables synesthésies. Cette stratégie syncrétique relève de la compétence discursive d'un seul et unique énonciateur, quand meme celui-ci s'actorialiserait très diversement". Tradução nossa.
} 
Hernandes (2005) fala sobre esta estratégia do enunciador do cinema, um texto sincrético por excelência, para capturar a atenção do enunciatário pela narrativa que se mostra aplicável também aos memes. Nessa manifestação textual, a primeira coisa que convida o olhar é a imagem, antes do verbo. Desde esse momento, onde o enunciado se constrói, o usuário-destinatário é preso por uma curiosidade que ainda está em segredo e está modalizado por um querer-saber. O sentido será por fim revelado na semiose do plano do conteúdo com o plano de expressão, revelando o "mistério".

Ainda na apreensão, a paixão despertada pode ser de malquerença, que leva à indignação, à raiva, a um querer-fazer mal, como se o ator do enunciado figurativizado no meme de política fosse merecedor da crítica que lhe é feita (BARROS, 2002, p. 67). A paixão de ódio se desenvolve em paixões mais complexas, de satisfação ou de alívio, quando a curiosidade inicial se desvela pela inesperada explosão cômica.

O enunciador do meme é o responsável por manter esse suspense pela escolha da imagem, pelo verbo e pelo todo de sentido que pretende passar para o enunciatário. Observar apenas a manifestação no seu plano do conteúdo ou olhar unicamente para o que é manifestado pelo plano da expressão seria ignorar que ambos são partes indissociáveis de estratégias enunciativas do enunciador do texto memético.

Nosso propósito é descrever semioticamente as estratégias enunciativas desse enunciador pressuposto, que toma corpo discursivo como um ator da enunciação. No nível discursivo, esse ator é composto por meio de um enunciador e de um narrador, no esquema de delegação de vozes, próprio à construção da sintaxe discursiva (FIORIN, 2016a). Para os memes, trata-se de um modo sincrético de produzir enunciados online. Enfatizamos que consideramos o autor dos memes um ator da enunciação que, para exercer tal função, desempenha um papel temático e um papel actancial no interior dos memes humorísticos de orientação política. Para isso, examinaremos a enunciação dos memes como uma enunciação sincrética.

Portanto, será necessário olhar para o meme epistemologicamente como uma unidade, apesar de diversas linguagens se dialogarem na construção desse tipo de texto. Para a professora e pesquisadora Lucia Teixeira, a respeito dos textos sincréticos,

A particularidade matérica das linguagens em jogo se submete a uma força enunciativa coesiva, que aglutina as materialidades significantes em uma nova linguagem. É por isso que se fala em linguagem cinematográfica, linguagem audiovisual, linguagem teatral, etc. $\mathrm{O}$ uso corrente dos termos, se não é inteiramente apropriado, pode ajudar a compreender a produção do efeito de unidade expressiva de uma nova 
linguagem. Desaparecem a linguagem verbal, a linguagem musical, a linguagem gestual e toma forma a linguagem cinematográfica, caso particular de sincretismo stricto sensu. Será diferente a metodologia de análise, em cada caso, porque, quando se está diante de uma semiótica sincrética em sentido estrito, a investigação pode examinar a qualidade própria de cada unidade ou grandeza, mas deve analisar, fundamentalmente, a estratégia enunciativa que sincretiza as linguagens numa unidade formal de sentido (TEIXEIRA, 2009, p. 58).

Conforme olhamos para os memes de internet como parte desse patamar de "nova linguagem" descrito por Teixeira, o que existe para nós é, além de uma enunciação sincrética, uma linguagem memética que une duas materialidades significantes, a verbal e a visual, na forma de uma única enunciação.

A linguagem dos memes de temática política, mais especificamente, como defende Chagas (2018, p. 11), ancora-se num determinado elemento de persuasão contido em uma mensagem resumida que procura convencer o destinatário, influenciando-o tanto sob um aspecto pessoal como também no aspecto relacional de sua propagação.

Por "mensagem resumida", podemos concluir, pelos nossos estudos discursivos, que se trata do conteúdo geral manifestado tanto verbal quanto visualmente pelos memes. Esse conteúdo na sua expressão também remete a um conteúdo temático-figurativo na sua imanência. Ora, na cadeia memética \#belarecatadaedolar, as imagens visuais remetem, e subvertem, a ideia do patriarcado reinante na sociedade brasileira, “condensadas" ou resumidas tão suscintamente e cujo sentido e ironia só podem ser construídos através de um conhecimento partilhado entre enunciador e enunciatário.

Conforme já afirmamos na parte introdutória do nosso trabalho, são exemplos de memes GIFs, vídeos, sons, imagens entre outros. Admitindo ser este um campo de trabalho bastante amplo e frutífero para uma investigação em todas as suas formas de expressão, vamos nos ater, nas nossas análises, aos memes de internet que possuem imagem estática com uma sobreposição verbal, também observados como textos sincréticos no senso estrito de sua definição. 


\section{HUMOR E TENSIVIDADE NOS MEMES DE POLÍTICA}

\subsection{A caricatura, o riso e o louco}

"Le sage ne rit qu'en tremblant"

Charles Baudelaire

Figura 13 - Meme "Pergunta ao Guedes"

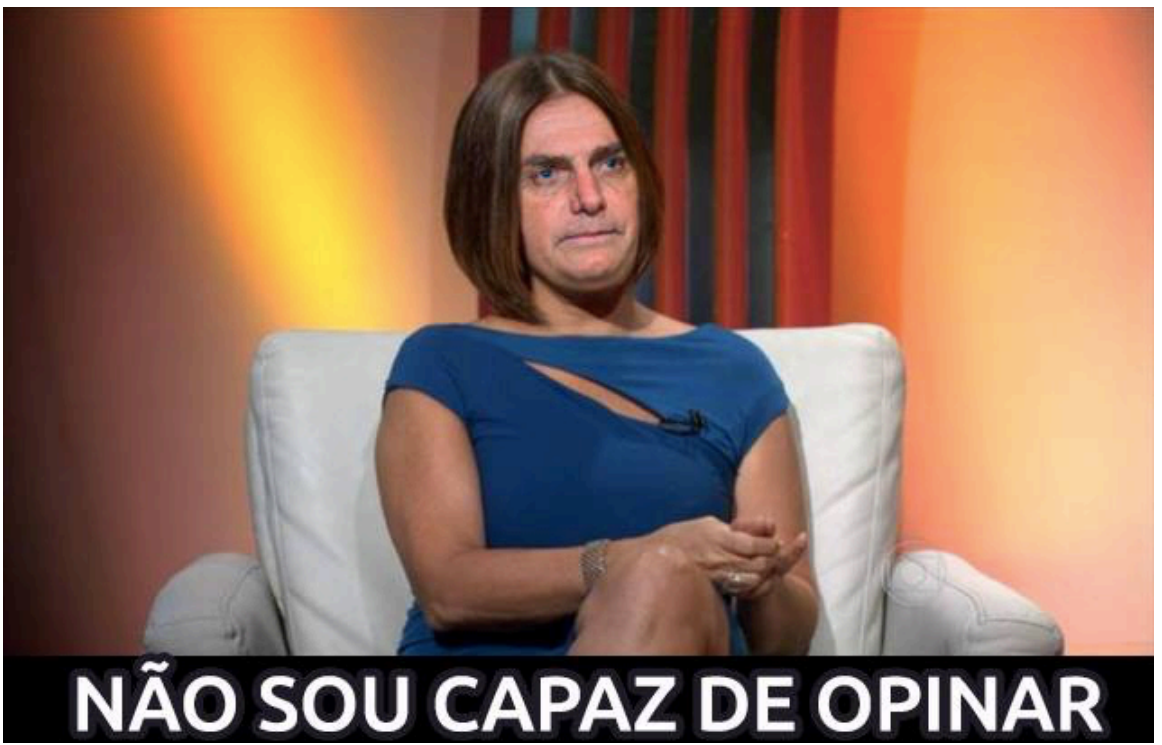

Fonte: https://segredosdomundo.r7.com/wp-content/uploads/2018/08/14-8.jpg. Acesso em 12 de fevereiro de 2020 .

O meme só é um meme quando se admite a existência de outro meme (FECHINE, 2018). O meme acima (Figura 13) se refere ao episódio (e à produção de memes que se seguiu) em que a atriz Glória Pires disse não ser capaz de expressar uma opinião ao ser questionada se a cantora Lady Gaga poderia levar o prêmio de melhor canção na premiação do Oscar. No entanto, no seu segmento visual, o rosto da atriz foi trocado pelo do presidente Jair Bolsonaro. O riso, segundo Baudelaire (2007), vem da quebra de expectativa, o que gera o efeito de sentido de surpresa resultando na explosão cômica. Porém, o meme também faz uma sátira ao presidente da República. A leitura é então dividida em duas: a imagem e a ideia. Para o autor, apenas com olhar malicioso e satânico é possível observar a debochada crítica que foi feita. Os conceitos de surpresa e humor serão discutidos nas linhas seguintes deste capítulo da nossa dissertação, dedicado ao riso e ao risível. 
O escritor simbolista e poeta do século XIX Charles Baudelaire (1821-1867) realizou um breve, porém interessante ensaio sobre o cômico intitulado Sobre a essência do riso (1997 [1885]). Longe de querer parecer um "tratado sobre a caricatura", Baudelaire (2007, p. 1) faz uma reflexão geral, ao mesmo tempo filosófica e artística, de atento olhar poético a respeito do riso e "suas relações com todos os fatos políticos e religiosos, graves ou frívolos, relativos ao espírito nacional ou à moda, que agitaram a humanidade [...]." (ibid., idem).

No começo do seu ensaio, Baudelaire relata a anedota cotidiana de um transeunte que tropeça acidentalmente no meio da rua, como se dela o próprio poeta tivesse sido um distante observador, sentado no banco de um parque como voyeur da cômica infelicidade alheia. Para o autor

Tomando um dos exemplos mais vulgares da vida, o que há de tão engraçado no espetáculo de um homem que cai no gelo ou na rua, que tropeça na beirada de uma calçada, para que a face de seu irmão em Jesus Cristo se contraia de modo desordenado, para que os músculos de seu rosto comecem a trabalhar subitamente como um relógio ao meio-dia ou um brinquedo de cordas? Esse pobre diabo ficou, no mínimo, desfigurado; talvez tenha fraturado um membro essencial. No entanto, o riso disparou, irresistível e súbito. Por certo, se se quiser aprofundar melhor essa situação, encontrar-se-á, no fundo do pensamento daquele que está rindo, um certo orgulho inconsciente. Aí está o ponto de partida: eu, eu não caio; eu, eu ando direito; no que me diz respeito, meu pé é firme e seguro. Não seria eu a cometer a tolice de não ver uma calçada interrompida ou uma laje que barra a passagem (BAUDELAIRE, 2007, p. 5).

O poeta francês conta a engraçada anedota do transeunte que perde o equilíbrio sem nenhuma candura da parte daquele que faz o relato, sem benevolência ou empatia da parte do observador da cena, mas com um olhar que cria o efeito de superioridade do observador em relação ao observado. O observador é alguém a quem esse passo "em falso" nunca acometeria. A cena é risível pela quebra de expectativa, pelo fator surpresa, pelo ser humano acreditar ser dela um observador alheio, dotado de superioridade idônea. É sempre o “ele", nunca o “eu”. Logo, o riso é para Baudelaire (2007) ao mesmo tempo satânico e grotesco, na acepção do próprio autor.

$\mathrm{Na}$ antiguidade, não há relatos ou retratos relativos às figuras históricas, eclesiásticas ou sacras, nem relativos às pinturas e esculturas gregas que nos levem à assunção de um período em que se gozava de uma certa dose de comicidade. Aristóteles não ri. Monges e sacerdotes da antiguidade tampouco. Segundo relata Baudelaire (ibid., p. 7), "Vênus, Pan, Hércules não eram personagens que provocavam o riso. Rimos deles 
após a vinda de Jesus, Platão e Sêneca tendo contribuído para isso. Creio que a antiguidade tenha muito respeito pelos tambores-mores ${ }^{27}[\ldots] "$.

Nesse ensaio, o autor, poeta e teórico da arte francesa abre o segundo capítulo com a máxima "o sábio só ri tremendo" (ibid., p. 2), de autoria desconhecida. De acordo com o dicionário Houaiss (2015), o sábio é aquele que tem extensos e profundos conhecimentos; que é sensato, prudente; erudito. O sábio chez Baudelaire (2007, p. 2) é aquele "animado pelo espírito do Senhor", portanto, não ri, pois teme o riso assim como teme os espetáculos mundanos.

Apontamos que o poeta e ensaísta leva em conta que o riso é um exercício mecânico e involuntário que pode ser desencadeado como reação ao acontecimento cômico; o sábio pensa antes de rir para que seu ato não cause nenhum mal-estar que comprometa a sua fé. A ciência se restringe à seriedade. $\mathrm{O}$ riso, por sua vez, pertenceria aos loucos, já que indica ignorância e fraqueza (ibid., p. 3). Ora, pois os loucos do hospício teriam, enfatiza bem o ensaísta Baudelaire, "a ideia de sua própria superioridade desmedidamente desenvolvida" (ibid., p. 5).

O riso cômico, de origem diabólica, também está intimamente ligado à subjetividade do observador. A superioridade do riso, como bem descreve Baudelaire, parte do princípio de que o observador, aquele que ri, é antes de tudo um ser orgulhoso. O cômico não pertence ao sábio e ao inocente, mas ao orgulhoso, ao louco que se julga superior, por essa razão o riso é satânico. Baudelaire exemplifica com a figura da virginal Virgínia, referência ao personagem homônimo da obra Paul et Virginie (1787), de Jacques-Henri Bernadin de Saint-Pierre, que, ao se deparar com uma caricatura no pátio do Palais Royal, não entende de imediato a sua sátira contra a monarquia francesa. A leitura da figura se divide em duas: o desenho e a ideia (BAUDELAIRE, 2007, p. 4). Necessitaria do olhar mundano e malicioso para compreender o deboche. Segundo o autor

[...] o desenho, violento; a ideia, picante e velada; complicação de elementos penosos para um espírito ingênuo, acostumado a compreender intuitivamente coisas simples como ele. Virgínia viu; agora ela olha. Por quê? Ela olha o desconhecido. Aliás, ela não compreende bem nem o que aquilo quer dizer, nem para o que serve. E, no entanto, vejam esse recuo de asas súbito, esse estremecimento de uma alma que se cobre e quer se retirar. $\mathrm{O}$ anjo sentiu que o escândalo estava ali. E, na verdade, eu lhes digo que, quer tenha ela compreendido ou não, ficar-lhe-á dessa impressão não sei que mal-estar, algo que se

\footnotetext{
${ }^{27}$ Suboficiais responsáveis pelos tambores e pelos clarins de um regimento. Os tambores-mores eram escolhidos entre os homens mais altos do regimento.
} 
assemelha ao medo. Certamente, caso Virgínia permaneça em Paris e tome conhecimento dos fatos, o riso lhe virá; veremos porque. Mas, por enquanto, nós, analista e crítico, que com certeza não ousaríamos afirmar que nossa inteligência é superior à de Virgínia, constatamos o receio e o sofrimento do anjo imaculado diante da caricatura (BAUDELAIRE, 2007, p. 4).

Como descreve Baudelaire,"[...] o riso dos lábios dos homens é sinal de uma miséria tão grande quanto as lágrimas de seus olhos" (ibid., p. 3); as causas do risível não são lógicas e nem racionais, mas partem de uma déraison (HAUGEN, 1988, p. 16), uma "falta de razão" se traduzirmos grosseiramente o termo do francês, que se situa do lado oposto ao da sabedoria. Interessante constatar que Baudelaire, já célebre escritor, opunha o cômico à arte cômica. O primeiro, "condenável e de origem diabólica" (BAUDELAIRE, 2007, p. 3), pela superioridade pressuposta daquele que observa, ao passo que a última seria "límpida e profunda" (p. 7), presente na alma dos sábios.

Para o artista, haveria dois tipos de cômico que ele distingue através das caricaturas: um significativo ou ordinário, e o outro absoluto ou grotesco. O ordinário, primeiro tipo, é o que Baudelaire vê como importante apenas pelo acontecimento representado na caricatura e, por isso, merece a atenção "[...] do historiador, do arqueólogo e até mesmo do filósofo e [essas obras preciosas] devem ocupar um lugar nos arquivos nacionais, entre os registros biográficos do pensamento humano" (2007, p. 1), que são o cômico da caricatura, da comédia de costumes feita apenas para arrancar o riso da plateia, o de linguagem familiar/vulgar, o de fácil compreensão, como da comédia de Molière, explica o poeta. Esses exemplos tratam do que o autor chama de cômico de "criação".

Já o cômico absoluto e o grotesco são motivos de grande admiração para Baudelaire (2007. p 1), já que “contêm um elemento misterioso, durável e eterno”. É a arte no seu estado mais puro. O grotesco, ao contrário do que o termo poderia nos fazer acreditar, não quer dizer o feio, o decrépito, a angústia dos autores românticos. Para o autor, o riso é aquela válvula de escape liberadora do carnaval e das festas populares (HAUGEN, 1988, p. 26), cotejando o pensamento de Bakhtin (1987) sobre o carnaval na idade média. O cômico puro de uma profunda observação da natureza, de um artista sensível que a descreve com perfeição na sua forma mais "crua", despindo-se de toda subjetividade caricatural. Por isso Baudelaire atribui a esse tipo de cômico a alcunha de "imitação".

A teoria bergsoniana, da qual trataremos mais adiante, diz que o desenhista 
cômico faz, através do exagero das formas físicas da personagem caricaturada, o nosso olhar desviar do cerne do cômico quando o que está em jogo é o aspecto moral (BERGSON, 2018, p. 86).

Aquele que cai na calçada é incapaz de rir de seu acidente. A potência do riso está mais naquele que ri do que no objeto do riso. A não ser que esse que cai seja um filósofo (aqui nos aproximamos da definição de sábio dada pelo dicionário citado, como aquele dotado de profundos conhecimentos) que ao se estrebuchar no chão é capaz de se desdobrar e rir da sua própria queda (BAUDELAIRE, 2007, p. 6). Esse seria um riso tanto significativo, pois leva o tombo e causa o riso no outro, quanto absoluto, pois é consciente de sua própria decadência; portanto, um sábio de extrema superioridade, que se junta ao público para rir de seus defeitos e das mazelas que os assolam em conjunto ao invés de ser deles um mero e distante espectador. O riso e as lágrimas, como diria Baudelaire (idem, p. 3), "não podem ser vistos no paraíso das delícias".

Henri Bergson (1859-1941) escreveu a sua obra “O Riso" (2018 [1900]) apenas alguns anos depois da publicação de Charles Baudelaire. Não faz menção, entretanto, ao tratado do cômico do grande escritor francês. Contudo, apesar de ambos se complementarem muitas vezes em suas teorias sobre o risível, eles também possuem visões divergentes acerca do humor que se extrai tanto do sujeito quanto da sociedade.

Nos escritos de Henri Bergson (2018), o autor afirma que o riso é um ato social por definição. O riso "precisa de um eco que ressoe como um trovão da montanha", mas que sua repercussão não se prolongue ao infinito; nas palavras do autor: "Ela [a repercussão] pode se mover dentro do maior círculo possível; nem por isso tal círculo será menos fechado. Nosso riso será sempre o riso de um grupo" (ibid., p. 39).

O riso, discute Henri Bergson (2018, p. 40), tem uma função social. Ele responde a exigências da vida comum, portanto deve ter uma significação social. Poderíamos dizer que o riso é um acordo estabelecido entre no mínimo dois falantes, logo, um grupo, que demarca o limite de sua extensão, não sendo possível agradar quem se apresenta fora dele.

O risível de Bergson vem da mudança da previsibilidade, da "regularidade matemática" a qual se espera, da falta de jeito de se adaptar ao imprevisto de desviar de uma pedra no meio do caminho. "[...] Por efeito de uma rigidez ou velocidade adquirida, os músculos continuaram a desenvolver o mesmo movimento quando as circunstâncias pediam outra coisa" (ibid., p. 40, grifo do autor) onde na verdade gostaríamos de ter visto uma maior flexibilidade do sujeito.

Bergson (idem) afirma, complementando o que dizia previamente sobre o 
mecânico, que o riso surge do rompimento do que há de enrijecido no ser. Aquele que, por exemplo, não vê o passo em falso que dá na calçada e acaba caindo (história já contada por Baudelaire e mais uma vez repetida nos estudos de Bergson) é motivo de risada pois não soube se adaptar ao percalço a fim de evitar a sua queda, enquanto que para Baudelaire o que há de mecânico é a contração muscular sintomática do rosto do gozador ao emitir o riso (HAUGEN, 1988, p. 13).

A respeito do humor, o seu grande inimigo é a emoção, segundo o autor. Bergson (2018) garante que a insensibilidade acompanha a piada. Observamos uma aproximação entre os dois pesquisadores do riso neste ponto. Ao humor que recai sempre sobre o outro (o que Baudelaire chama de "superioridade"), Bergson dá a alcunha de "indiferença". Não é engraçado que o sujeito "sinta com aqueles que sentem" (ibid., p. 38). Num mundo de almas sensíveis, pouco se compreenderia o motivo do riso. Porém, observar a mesma cena que normalmente levaria ao desespero ou às lágrimas dando um certo recuo, como um espectador indiferente, muitos dramas se transformariam em verdadeiras comédias. "Basta que tampemos os ouvidos ao som da música em um salão de dança, para que imediatamente os bailarinos nos pareçam ridículos" (ibid., p. 39).

No entanto, essa indiferença não deve isolar o sujeito. Todo riso continua sendo um ato conjunto, tanto que ele tem a necessidade incessante de um eco. Ao ouvir uma conversa no transporte público entre pessoas que parecem trabalhar juntas, um cidadão nota, em determinado momento, que elas começam a gargalhar. $\mathrm{O}$ espectador não ri por não fazer parte daquele grupo, por não trabalhar na mesma empresa ou não conhecer as pessoas de quem se fala. Sem nenhum desses fatores, a vontade de rir do cidadão é nula. O riso é sempre previamente negociado.

O contrato do riso é acertado entre os participantes da comunicação de maneira quase empírica, enunciador e enunciatário. Entre erros, acertos e ajustamentos. Retomando o objeto de nosso estudo, que são os memes políticos, aquilo que é publicado online é destinado a um enunciatário pressuposto, cabendo a ele decidir se aceita ou não aquele contrato como verdadeiro, baseado em interesse, crença e afeto.

Neste sentido, o autor dá uma especial atenção ao humor produzido pela linguagem: “As frases não se fazem sozinhas" (BERGSON, 2018, p. 82). Se rimos delas, torna-se uma tarefa difícil dizer se estamos rindo das palavras pronunciadas e (ou) do seu autor, daquele que a enuncia. Admite-se que muito do riso provém da ação da natureza sobre a vida mecânica, graças a uma precisa seleção vocabular. Apenas se olharmos para o rigor da construção frasal, este talvez seja facilmente traduzido "ao pé da letra" para um 
interlocutor cuja língua, cultura e literatura sejam diferentes.

Admitamos que as frases não são produzidas sozinhas nem fora do ambiente social. Se rirmos de uma piada ou de um fato poderemos muito bem rir de quem os conta (BERGSON, 2018, p. 82). Porém, ao dispensarmos esta última afirmação, a palavra, as frases, ou melhor, o enunciado em si terá uma força cômica toda própria independente de quem seja o seu autor de "carne e osso".

Nem Bergson nem Baudelaire poderiam ter pensando nos memes anos antes do advento da internet, porém seus ensaios continuam atualizados e nos fazem refletir sobre a maneira como interagimos com (e através do) o humor. Fazendo um recorte sócio histórico, os memes, assim como a caricatura, são indicadores da cultura e dos fatos acontecidos numa determinada época, apesar de serem efêmeros. Ou seja, não são uma arte que possamos chamar de "eterna" pelas palavras de Baudelaire (2007), pois se assemelham à comédia de costumes, à "paródia do publicamente conhecido" (FELINTO, $2008^{28}$ apud CHAGAS, 2017, p. 180), de fácil reconhecimento e repetida tantas vezes como quando um personagem recebia uma torta na cara em um antigo programa humorístico da TV. Quando se apela para o humor fácil, o riso é inevitável.

Entretanto, para a semiótica, o meme é visto como um gênero discursivo, que se concretiza por meio de textos sincréticos. A recorrência do modo todo próprio de dizer funda o estilo do gênero memético. Tampouco pensamos, como semioticistas, em sujeito de carne e osso, em situação real em que teria ocorrido a ridícula cena. Observamos a cena que comporta o ridículo como construção da linguagem, do texto e do discurso. Para semiótica standard se pensa na manipulação do enunciador memético em relação ao enunciatário. Além do mais, também pensamos no estilo sancionador do enunciador memético, que acaba por sancionar muitas vezes um "ele", que pode ser um ator do enunciado, por meio da punição, que é a sátira.

Ao rirmos de um meme, ora estamos rindo do personagem (ator do enunciado), ora estamos rindo com o enunciador, ora estamos rindo de "nós" como enunciatários. Contudo, não é possível afirmar semioticamente que o riso possui uma sensibilidade nula pela relação estabelecida entre a intensidade do sentir e a inteligibilidade das coisas (a extensidade) a fim de descrever a construção do sentido nos enunciados sincréticos do meme. Afirmamos, apoiados nos desdobramentos tensivos de Zilberberg (2011), que a sensibilidade resulta num grau quase nulo de intensidade. A sensibilidade memética se

\footnotetext{
${ }^{28}$ FELINTO, E. Videotrash: o Youtube na cultura do “spoof” na internet. Galáxia, São Paulo, 2018.
} 
torna então mitigada, o que indica que o sensível ainda está lá, na construção do humor do meme. Rimos com o posicionamento do enunciador, que apresenta normalmente voz delegada para um actante do enunciado, o interlocutor, o ator do enunciado, que fala "eu", mas como voz delegada pelo narrador. A voz do narrador, que instala no enunciado o efeito de humor, acaba por fortalecer a cumplicidade que diz respeito tanto ao enunciador quanto ao enunciatário.

Fiorin (2004) confirma que o enunciador é tão produtor do enunciado quanto o enunciatário; no momento em que o enunciador produz um texto, "ele" tem uma imagem do enunciatário em mente. Esta imagem também se converte no ator da enunciação (ibid., p. 69). A imagem enunciativa (enunciador e enunciatário) é sugerida nos memes como um sujeito ao mesmo tempo irônico e moralista, de quem e com quem damos risadas.

\subsection{Ironia, humor e jogo de trocas}

Quando se enuncia "aquilo que deveria ser, fingindo acreditar que se trata justamente do que é" (BERGSON, 2018, p. 92), este é então o conceito da ironia na concepção bergsoniana. Já o sujeito voltado para o humor, à sua vez, finge acreditar que se trata do que é (ibid., idem). Tanto a ironia quanto o humor são formas de sátira, defende o autor, mas há um contraponto importante a ser feito a respeito destes.

Expliquemos melhor: o humor é o correlato inverso da ironia, segundo Bergson (idem). Enquanto o humor é de natureza científica, a ironia é da ordem da oratória. Esta última se eleva se aproximando da ideia do bem que deveria existir na sociedade segundo o mundo narrado no enunciado. Ou seja, a ironia revela mais sobre quem dela faz uso do que sobre o assunto do discurso em si, ao passo que o humor está mais atrelado à ciência e aos fatos, defende o autor.

Lembramos que o discurso memético se ancora na fonte de ironia, como descreve Bergson (2018). Os memes se constituem de um discurso em que costuma ocorrer a simulação de uma conversa com o enunciatário. Quando isso ocorre, o meme corrobora o efeito de comunicação corriqueira, um efeito de proximidade. O enunciatário aparece apenas quando por meio de recursos de textualização, no emprego de um " $t u$ ", dirigido ao próprio leitor. Caso contrário, a instituição do leitor permanece implícita, porém está sempre lá presente. O leitor memético precisa ler os implícitos, daí a cumplicidade. Portanto, trata-se de um discurso irônico, em que o enunciador constrói de si a imagem de um olhar de superioridade sobre o evento instaurado no interior do meme. $\mathrm{O}$ 
enunciador aponta para uma autoimagem de alguém justamente superior, cômico e moralizante.

Figura 14 - Meme "Não pecarás"

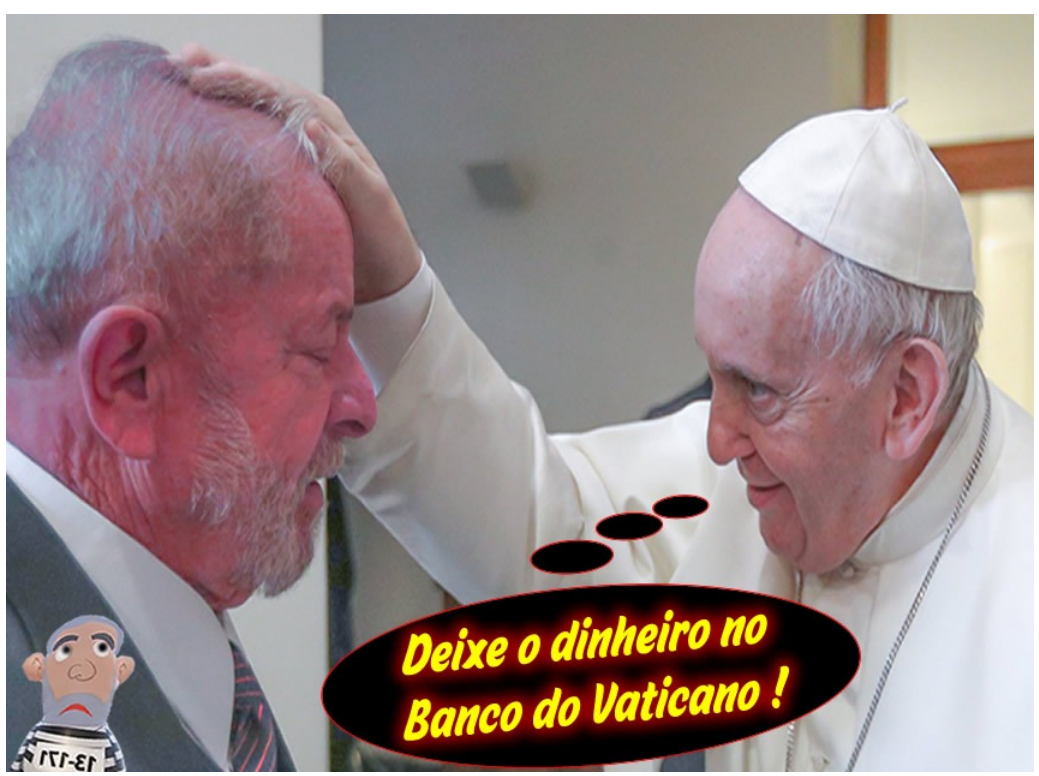

Fonte: https://1.bp.blogspot.com/-p-

qY TsLoTY/XkXeVemve0I/AAAAAAAAJk4/Ml4I0AzYhCwR3PYMn24rShMfpcCkfYXAACNcBGA sYHQ/s1600/lula\%2Bbanco\%2Bvaticano.jpg. Acesso em 14 de fevereiro de 2020.

Pela semiótica, podemos pensar que o riso se confirma através de um gesto social que "[...] reprime as excentricidades [...]; suaviza, enfim, tudo que puder restar de rigidez mecânica na superfície do corpo social” (BERGSON, 2018, p. 45).

A comicidade reprime hábitos e reconsidera a visão do homem para a sociedade em que vive. Entretanto, em paralelo, ela tem por função humilhar seu objeto de humor. O riso, segundo o ensaísta, não busca o diálogo, "não se dá o prazer de olhar o que toca" (ibid, p. 123), apenas julga sem querer resposta alguma: "Não teria sucesso se, para tanto, a natureza não tivesse deixado, entre os melhores homens, um pequeno fundo de maldade ou, ao menos, de malícia" (ibid., idem). Contudo, numa descrição semiótica, e indo de encontro com os estudos de Bergson, o diálogo é primordial, visto que a ironia é bivocal, ou seja, tem duas vozes. Uma voz afirma o que é dito no enunciado, enquanto a outra nega na enunciação.

Depois de abordar brevemente a teoria do humor, voltamos ao nosso objeto de pesquisa, o humor nos memes políticos. Para o pesquisador Viktor Chagas (2017), o 
humor memético se relaciona com o kitsch. Para Chagas, a combinação de uma linguagem popular e uma imagem que ridiculariza o ser político faz parte de uma estratégia de aproximação, pela exaltação que faz ao fait divers (eventos da vida cotidiana noticiados pela imprensa), aos elementos da cultura popular e à piada situacional (CHAGAS, 2017, p. 181).

Como na caricatura, busca-se extrair o riso da exacerbação dos traços físicos e morais da figura. Para Chagas (2017), os aspectos positivos e negativos de um candidato são ressaltados na produção do humor. Trazendo para o âmbito da análise semiótica, observamos que a atenção é então voltada para o observador-narrador, este delegado pelo enunciador do texto meme. Cabe ao narrador o julgamento. O contrato de veridicção é estipulado a partir do que é "sabido" pelo enunciatário. Não é permitido que se atribua à figura política retratada, ator do enunciado, uma qualidade que não seja conhecida pelo seu leitorado, enunciatário memético, ou poderíamos estar diante de uma falsidade (além de "não parecer" também "não é”). Na sua missão de viralização, o meme perderia força e adesão por parte desse leitorado.

Contrariando a noção de brincadeira caótica que se dá online e que goza de expressiva liberdade na produção do humor, os memes possuem regras. O enunciador, primeiramente, deve supor que o enunciatário conheça e respeite certas regras do jogo, sabendo se tratar o meme de um enunciado satírico e não sério, por exemplo. Segundo, ao que seria equivalente à concepção de memes por Dawkins (2007), na questão da fidelidade da cópia concebida pela imitação de outros exemplos já existentes, os usuários tendem a seguir modelos anteriores e assim cria-se o jogo que podemos pensar ser intrínseco ao gênero meme. Segundo Shifman

$\mathrm{Na}$ teoria, todos os usuários da Internet são espíritos livres, indivíduos que seguem seu caminho único para o hall da fama digital. Na prática, eles tendem a seguir os mesmos caminhos já trilhados da criação de memes. Esses caminhos podem ser pensados como gêneros memes ${ }^{29}$ (2014, p. 100).

Assumimos os enunciados meméticos como um jogo de trocas entre os usuários conectados, Greimas (2007) nos fala, a exemplo de uma partida de xadrez, em que é preciso reconhecer o jogo como uma estrutura na qual atuam os jogadores. Estes não são

\footnotetext{
${ }^{29}$ Do original em inglês "In theory, all Internet users are free spirits, individuals who take their unique path to the hall of digital fame. In practice, they tend to follow the same beaten tracks of meme creation. These paths can be thought of as meme genres". Tradução nossa.
} 
meros actantes, mas são também sujeitos "históricos", com competência modal e semântica. Como o próprio diz

Desse modo, não é legítimo considerar os jogadores implicados em uma partida no hic e no nunc como actantes abstratos. Eles são sujeitos históricos, e isso de um duplo ponto de vista, na medida em que, além de possuírem uma competência semântica específica que se deve em grande parte a suas performances anteriores, possuem também uma competência modal mais ampla que, indiferente ao campo de exercício do jogo escolhido, determina seu fazer programador (GREIMAS, 2007, p. 16).

Para Greimas (idem), o prazer proveniente do jogo precisa ser compartilhado. Sendo a sua função última sair da partida vencedor, os participantes não gozam apenas de uma comoção solitária ao observar a eminência da vitória, do seu próprio poder-fazer, mas também do fazer-saber: “A vitória só é completa se, oferecida a seu interlocutor, ela for sancionada pelo reconhecimento do outro. No jogo, não se trata somente de vencer, mas de "con-vencer", de obrigar a partilhar seu trunfo" (ibid., p. 18, grifo do autor).

O homem que se apresenta dentro de um sistema coercitivo, que é o político, encontra uma maneira de "sentir-se à vontade". O sujeito lúdico encontra uma liberdade no jogo dos memes, uma "maneira de ser livre", criando como efeito de sentido um estado no qual agir de acordo com essa maneira de ser livre garante ao homem sua plenitude (GREIMAS, 2007, p. 20-21).

Chagas faz o alerta de que os memes parecem surgir de uma militância espontânea que se une para alavancar os votos de determinado candidato (CHAGAS, 2017, p. 181). Novamente, teríamos que discordar do autor. O meme é feito na atenção de outrem. Valendo-se da organização enunciativa e veridictória (o parecer verdadeiro de um discurso dito científico, por exemplo, dos discursos próprios da internet), levando em consideração também a possibilidade do anonimato (BARROS, 2015), o enunciador dos memes, este de olhar "malicioso" típico de um atento observador, como nos indicam Charles Baudelaire (2007) e Henri Bergson (2018), aparece para nós como um sujeito de aspecto télico e de perfil judicativo (DISCINI, 2015) pelo seu caráter crítico e julgador, que encontrou na web uma maneira de construir uma rede com outros usuários que se identificam e se relacionam com o conteúdo por ele difundido.

A identificação, segundo Greimas (2014, p. 131), ocorre quando há um "reconhecimento" da verdade que nada mais é que uma "operação de comparação" entre aquilo que se propõe e aquilo que já se sabe ou se crê. Nas palavras do autor 
se o ato epistêmico é uma identificação, ele se vale do universo do saber/crer do judicador. O reconhecimento da 'verdade', que até Einstein, inclusive, era definido por sua adequação à 'realidade' referencial, o é agora pela adequação a nosso próprio universo cognitivo (GREIMAS, 2014, p. 131, grifo do autor).

Michel Temer, na condição de presidente da república, conforme explicamos na nossa introdução, então como presidente em exercício, proibiu a publicação de memes com o uso de fotos oficiais do governo sem o devido crédito de quem as produziu. Pelo artigo 53 da Lei Eleitoral (Lei 9504/1997) fica proibido o uso de propaganda que fale mal ou denigra a imagem do oponente, sendo responsabilizado caso o autor seja identificado ${ }^{30}$.

Ora, o meme já pressupõe um autor anônimo que não se responsabiliza nominalmente (muito menos moralmente) pela crítica que faz. O emprego recorrente do discurso direto, em enunciação do segundo grau (quando o ator do enunciado, o personagem diz "eu” ou " $t u$ ”), discurso no qual a voz do narrador é delegada ao ator do discurso, faz o jogo da enunciação da memesfera ser interessante e convidativo do ponto de vista de seus participantes.

Em um enunciado, como no que se admite que o ex-presidente Lula é ladrão (Figura 14), há pressuposição de um “eu” (que não é o ator real do meme, mas o enunciador) que sugere ao leitor que tanto Lula, que foi apontado pelo mundo noticioso por ter uma suposta conta no Banco do Vaticano, como o papa são ladrões - um é cúmplice do outro. Por isso o tema dinheiro, corrupção política tanto de um como de outro, está na concretização dos mecanismos de construção do sentido do meme.

Sempre haverá um ator da enunciação em qualquer texto. No entanto, o ator da enunciação pode simular sua própria ausência quando domina o efeito de objetividade, isto é, quando não há a figura de uma narrador explícito.

Daí vem a questão do anonimato. Nesse caso, o enunciador se aninha no simulacro de um ator coletivo. Não sabemos quem é o indivíduo que fez o meme. Desse modo, cai por terra o efeito de individualidade como um enunciador único. O semioticista Marcos Kalil Filho (2019), nos seus estudos sobre as fake news e o frequente uso do anonimato nas redes para divulgação de conteúdo falacioso, defende que na ausência semântica de um ator da enunciação, que vemos figurativizado como o autor da notícia, “(...) essa

30 JING, Yi Tsai. Os Memes como recurso de campanha negativa apócrifa na política. \#MUSEUdeMEMES. Disponível em: https://www.museudememes.com.br/os-memes-como-campanhanegativa-apocrifa-na-politica/. Acesso em 15 de fevereiro de 2020. 
lacuna acaba sendo preenchida, em certas plataformas, como o WhatsApp, pela autoria de grupos de conversação ou pessoas específicas” (KALIL FILHO, 2019, p. 213), porém partindo sempre de uma relação de confiança de amizade ou familiar que leva o fazercrer (persuasivo) do enunciador a um fazer-fazer (interpretativo) do enunciatário. Segundo afirma o pesquisador

[...] o fazer persuasivo, que confere certeza e verdade ao fazer interpretativo, locupletar-se-á da ausência de um ator da enunciação para que pais, chefes, parentes, líderes religiosos e amigos, ao compartilharem as mensagens em suas redes, ocupem essa posição de autoria. Esta foi, aliás, a estratégia bem-sucedida nas eleições de 2018, atribuída ao presidente Jair Bolsonaro e sua equipe. As instâncias tradicionais de mediação de informação e construção de certeza e de verdade - a imprensa, a Academia e as agências estatais, todas adeptas, no discurso, à 'camuflagem objetivante' - são substituídas pelo apelo subjetivo de mensagens de conhecidos. O 'eu fiador', portanto, recai sobre quem repassa a mensagem e valoriza a proximidade em contraste com o distanciamento e a impessoalidade do jornalismo, da ciência e do Estado (KALIL FILHO, 2019, p. 214).

O fiador do discurso, que é uma representação coletiva da imagem positiva do enunciador para Maingueneau (2018, p. 108), é construído a partir de indícios textuais e a ele são atribuídos um caráter e um corpo. O éthos, através do observador, remete à imagem desse fiador-julgador que “[...] confere a si próprio uma identidade compatível com o mundo que ele deverá construir em seu enunciado" (ibid., idem), através de um sistema de valores todo próprio. Logo, mesmo diante do anonimato do meme, o éthos, como fiador, está lá, embora seja ele um enunciador actante coletivo.

O fato noticioso, ou às vezes o espanto que tal fato nos causa, o discurso característico do sujeito político, é "suavizado" como diria Bergson (2018), pelo viés cômico. Suavizados na acepção tensiva de fazer o sensível descender para fazer valer a racionalidade de persuasão política.

Para a Semiótica Discursiva, ao se adotar o princípio tensivo, a emoção não é inimiga do riso. A emoção decai tensivamente para o quase zero de intensidade. O meme possui grande alcance graças a sua capilaridade, que faz o fato noticioso parodiado pelo memista ganhar projeção pelas redes sociais, dando a ele menor impacto e maior duração na memória dos usuários. O humor tem um papel fundamental na ampliação do conteúdo memético (SHIFMAN, 2014).

O memista, ou memeiro, o produtor do meme, não é interessante do ponto de vista semiótico como um sujeito biografado. Pelas teorias paralelas à semiótica nas quais também nos debruçamos para nossa pesquisa, ao não proclamar autoria, acaba-se por 
afastar o meme à imagem do seu criador. $\mathrm{O}$ benefício da dúvida a respeito do autor faz parte da regra do jogo.

Entretanto, se para o enunciatário memético a autoria não tem importância, para os estudos discursivos mantemos nossa posição de que o enunciador está sempre lá. Este é um princípio de ouro da semiótica. Para pensar em ator da enunciação dos memes, é necessário admitir que o enunciador está sempre presente em cada meme. Por isso os textos meméticos, por terem sua mira enunciativa em um grupo específico de enunciatários, deixam marcas e traços de um estilo, de um éthos e um caráter que convergem para a figura do ator da enunciação pela crítica que subjaz seu humor. É este último que está "à solta" nos memes de orientação política e "à procura" nesta nossa dissertação.

Afirmamos que o humor do meme faz aumentar a extensão temporal e espacial da notícia, do discurso ou do conteúdo que com que mantém relações interdiscursivas. Já a intensidade do fato noticiado, um discurso do sujeito político excessivo, vê sua tonicidade decrescer ao se tornar alvo da sátira do meme.

A intensidade e a extensão do discurso são assuntos abordados pelo ponto de vista tensivo da Semiótica Discursiva inaugurados por Claude Zilberberg (2001), os quais investigaremos no nosso próximo ponto.

\subsection{A tensão do cômico: natural x social}

Partindo da premissa de Bergson (2018) de que para haver o cômico e obter o riso deve-se haver uma "anestesia momentânea do coração", consideramos semioticamente o cômico como da ordem do inteligível, a partir dos estudos da tensividade (ZILBERBERG, 2001, 2007, 2011). Nós nos propomos a investigar, nesta parte do trabalho, as relações de tensão que ocorrem entre o humor encontrado nos memes cunhados na política brasileira e os fatos do mundo noticioso que circulam na imprensa escrita e digital.

Destarte, salientamos a noção de sujeito, que para a semiótica é tão cara. Tanto o observador de que fala Bergson (idem) quanto aquele que sofre a sátira do humor, de quem se ri, são actantes sintáticos cuja natureza depende da função na qual eles se inscrevem. Se for o enunciador e o enunciatário, estamos na cena enunciativa (GREIMAS; COURTÈS, 2012, p. 21). Se for considerado o personagem, ator do enunciado, estamos numa cena enunciva. Nesta última, temos uma debreagem actancial 
relativa a um "ele", mas que pode assumir a voz como "eu", caso em que será um interlocutor, como prevê Fiorin (2016a).

$\mathrm{O}$ ator da enunciação dos memes possui uma competência própria. A competência do sujeito é adquirida durante o esquema narrativo proposto por Algirdas J. Greimas, pelo qual, depois de passar pela manipulação do destinador e se "desvencilhar de todas as dificuldades por antecipação" (ZILBERBERG, 2011, p. 284), ele finalmente será um sujeito realizado de acordo com a lógica implicante (se a, então b) (idem, 2007, p. 23).

O sujeito semiótico, entretanto, segundo a Semiótica Discursiva, pode não se configurar como um agente ou como um sujeito ativo, mas como um sujeito "paciente" que se confronta com o estatuto modal do objeto contemplado (DISCINI, 2019). Neste último caso, ou seja, o sujeito paciente, estamos no âmbito do sujeito sensível, tal qual estudado pela semiótica tensiva.

Diz o criador da gramática tensiva: “[...] quem é esse sujeito que, por vezes a contragosto, vê o acontecimento irromper e revirar o seu campo de presença?" (ZILBERBERG, 2011, p. 284, grifo do autor). Esse sujeito sensível está também nos memes.

Para Luiz Tatit (2019), umas das marcas da diferença entre a teoria chamada standard e o ponto de vista tensivo é a eliminação "de surpresas e sobressaltos que pudessem conturbar a espera do sujeito e a sua conjunção à distância com o objeto de valor" (ibid., p. 40). Na teoria da narratividade de Greimas, a partir da obra Sémantique Structurale (1966), os papéis actanciais dos sujeitos já são postos de acordo com a valoração axiológica do nível fundamental, ocorrendo a sua homologação no nível narrativo. No encontro com o objeto de valor ao final do programa narrativo, já em conjunção, “o sujeito torna real o valor que não era senão visado e 'realiza' a si próprio" (GREIMAS; COURTÉS, 2012, p. 196).

Por essa razão, ele é o sujeito da espera, ou paciente, parafraseando Discini (2019), o qual aguarda o desenrolar da narrativa já prevendo o seu desfecho. O sujeito em falta ou potencializado estará realizado, pleno, obedecendo a uma ordem implicativa da sua própria programação, como vimos anteriormente na parte deste trabalho dedicada ao percurso gerativo do sentido. Há com certeza o sujeito performativo na performance de persuasão dos memes. Por isso ele é aspectualmente télico. Porém, há também a presença do sensível.

Para a semiótica tensiva, o lugar de encontro sensível-inteligível entre o sujeito e o objeto é chamado de campo de presença. De acordo com Fontanille e Zilberberg (2001), 
o campo de presença é o espaço tensivo e teórico onde se encontram a extensidade e a intensidade, essas duas valências da tensividade. O primeiro é a relação com o mundo inteligível, o estado das coisas, enquanto o segundo é da ordem do sensível, o estado de alma. A extensidade, por sua vez, possui dois funtivos que são a temporalidade e a espacialidade, ao passo que a intensidade se subdivide em tonicidade e andamento, sabendo-se que, para a teoria tensiva, o sensível é sempre regente do inteligível. Ainda segundo o ponto de vista tensivo, o acontecimento que entra no campo perceptivo do sujeito de maneira abrupta é da ordem da concessão. Para Barros, que retoma Zilberberg (2011), entende-se por acontecimento

[...] aquilo que arrebata ou ainda que choca o sujeito [...]. Logo, o acontecimento diz respeito a uma grandeza que entra no campo de presença de um sujeito muito antes que se possa prever sua chegada, arrebatando-o de tal forma que esse sujeito, num primeiro momento, sente dificuldade em compreender o que lhe ocorreu. Logo, quanto ao andamento, o acontecimento é a experiência do acelerado, quanto à tonicidade, é a experiência do tônico. Justamente pelo fato de o sujeito ser inteiramente tomado pelo acontecimento é que ocorre, do lado da extensidade, do inteligível, a aniquilação momentânea da temporalidade e a oclusão radical da espacialidade (BARROS, 2019, p. $500)$.

Segundo Zilberberg (2011), a dualidade entre a concessão e a implicação (esta sendo o correlato da primeira) fornece ao sujeito uma fisionomia ambivalente, quer dizer, uma intersecção de duas valências, uma intensiva e outra extensiva, que

[...] faz do sujeito de estado um ser ao saber do acontecimento que o despoja, sem a menor cerimônia, das competências geradoras de sua confiança em si e de sua coragem diante das adversidades da vida cotidiana. Em compensação, a dualidade dos grandes operadores discursivos [implicação vs. concessão] atribui ao sujeito operador uma capacidade de denegação - segundo alguns, de revolta - que lhe permite contradizer o que foi dito (ZILBERBERG, 2011, p. 285-286).

Voltando ao que vimos de teoria paralela à semiótica, na discussão sobre humor, riso e outros tópicos relativos aos mecanismos de construção do sentido dos memes, lembramos que de acordo com Bergson (2018), a vida e a sociedade exigem de nós uma constante atenção para a descrição de uma determinada situação que nos acontece e uma elasticidade para que possamos a ela nos adaptar: "não basta viver, é preciso viver bem" (ibid., p. 44). Face ao outro, num mundo repleto de vontades particulares, há de existir um trabalho permanente de adaptações mútuas por entre as partes uma vez que o equilíbrio recíproco entre elas nem sempre é alcançado. 
Bergson enxerga o humor, sendo o riso um gesto social, surgindo de algum lugar entre a tensão do mundo social e a maleabilidade que possuímos em nos adaptar às novas situações que vão surgindo ao logo do caminho. Por isso que se diz ser a rigidez das regras sociais o cômico, e o riso a sua correção (ibid., p. 45), ou melhor, sua adequação.

$\mathrm{O}$ autor de $O$ Riso diz que toda rigidez de caráter será julgada como um isolamento social de acordo com as leis do senso comum sob as quais a sociedade gravita. Em falta de uma melhor resposta para o que fere os princípios propostos pela doxa, ou a lógica do mundo comum, não se sanciona, por exemplo, o pedestre que caiu na rua, pois não houve de fato uma ameaça ao bom funcionamento da vida em sociedade, mas simplesmente pressentiu-se um (mau) sintoma ou um gesto. Diante da cena incomum, é com um outro gesto que se responde: o riso (BERGSON, 2018, p. 45).

Para que o riso aconteça, não devemos esquecer, nem momentaneamente, as relações afetivas que agem sobre nós no momento em que ocorre o acontecimento. Pelo contrário, consideraremos o sensível, que rege o inteligível, como quase zerado. Por isso se vai "silenciar a piedade" (BERGSON, 2018, p. 38), podendo fazer a compreensão pela categoria do inteligível, pela razão. $\mathrm{O}$ autor resume o riso cômico como

[...] este lado da pessoa pelo qual ela se assemelha a uma coisa, este aspecto dos acontecimentos que imita, por sua rigidez de um tipo bastante particular, o mecanismo puro e simples, o automatismo, o movimento sem vida, enfim. Exprime, portanto, uma imperfeição individual ou coletiva que chama por uma correção imediata. O riso é justamente essa correção. O riso é um gesto social, que sublinha e reprime uma certa distração especial dos homens e dos acontecimentos (BERGSON, 2018, p. 75, grifo nosso).

Evidenciamos que os desvios que Bergson tanto menciona em sua teoria sobre o risível não correspondem às surpresas e aos acontecimentos tensivos, que carregam consigo um grau máximo de emoção, mas tangenciam esse lugar tensivo, logo concessivo, pois fogem do automatismo do corpo que entra em tensão com as adversidades da vida dinâmica e movimentada. Evocamos mais uma vez a cena do passante que cai na rua e rimos, pois há uma quebra do que está na ordem da espera "ele caiu, embora nada estivesse errado com a calçada". Eis a surpresa que toca de leve o acontecimento tensivo.

Portanto, no pensar semiótico estamos afastados dos preceitos de determinada teoria a respeito do humor. Segundo os preceitos da Semiótica Discursiva o riso estaria enquadrado naquilo que se desenvolve de ordem implicativa. O riso para as teorias paralelas de que vimos falando ao longo deste capítulo é visto como um movimento 
involuntário dos músculos que agem subitamente no rosto do ridente como uma "[...] convulsão nervosa, [...] comparável ao espirro e causado pela visão da infelicidade de outrem" (BAUDELAIRE, 2007, p. 5). Já para a semiótica o acontecimento passa a ser um efeito de sentido construído pelo texto e, conforme o tratamento tensivo oferecido pelo narrador/ enunciador, aponta para maior ou menor tensão entre o evento e a sanção exercida sobre ele. Em outras palavras, entre a emoção e o exercício do dizer.

\subsection{Entre o acontecimento noticioso e o exercício através do cômico}

Para a semiótica tensiva, Zilberberg explica que o acontecimento provém de três diferentes modos semióticos. A saber: o modo de eficiência, o modo de existência e o modo de junção. Implicação e concessão compõem o modo de eficiência idealizado por Zilberberg em Elementos de Semiótica Tensiva (2011), dando continuidade ao projeto de uma gramática tensiva iniciado na obra Essai sur les modalités tensives (1981). Para Zilberberg, eficiência designa

[...] a maneira pela qual uma grandeza se instala num campo de presença. Se o processo for efetuado a pedido, segundo o desejo do sujeito, nesse caso teremos a modalidade do conseguir $^{31}$. Se a grandeza se instala sem nenhuma espera, denegando o ex abrupto as antecipações da razão, os cálculos minuciosos do sujeito, teremos a modalidade do sobrevir. Do ponto de vista paradigmático, o modo de eficiência é estruturado pela distinção do conseguir e do sobrevir (ZILBERBERG, 2007, p. 18).

O sobrevir estaria para o acontecimento assim como o exercício estaria para o pervir. Utilizado na língua francesa de forma comum, o termo sobrevir, de acordo com o dicionário Le Micro Robert (2008), é o que se apresenta de maneira improvisada, de repente, mais ou menos súbita. Já o pervir é o esperado. O acontecimento (sobrevir) teria então o exercício (pervir) como o seu correlato.

Já o modo de existência é o que diz respeito à apreensão do sujeito (quando tomado pelo acontecimento, pela admiração do ineditismo, o sujeito “"às voltas' com o sobrevir”) (ZILBERBERG, 2007, p. 22) e a seu foco; quando o fato é esperado, o sujeito já não é mais acometido pela surpresa, regido pela categoria do pervir.

\footnotetext{
${ }^{31}$ O termo "conseguir", o qual aparece na Figura 15, foi traduzido do original em francês "parvenir". Em outras obras traduzidas do autor para o português brasileiro, o termo aparece como "pervir". Acataremos essa última tradução para o português, que estará também presente em outras citações feitas ao longo do nosso trabalho.
} 
O modo de junção, por sua vez, é implicativo ou concessivo. Implicativo quando há uma causalidade lógica "se a, então b" (ibid., p. 23) entre o direito e o fato, e concessivo quando o direito e o fato discordam mutualmente "embora a, entretanto b" (idem, ibidem).

Podemos melhor visualizar nossa explicação acerca do acontecimento e do exercício da seguinte forma:

Figura 15 - A estrutura do acontecimento

\begin{tabular}{|c|c|c|}
\hline $\begin{array}{l}\text { determinados } \rightarrow \\
\text { determinantes } \\
\downarrow\end{array}$ & $\begin{array}{l}\text { o exercício } \\
\downarrow\end{array}$ & $\begin{array}{l}\text { o acontecimento } \\
\downarrow\end{array}$ \\
\hline modo de eficiência $\rightarrow$ & conseguir & sobrevir \\
\hline modo de existência $\rightarrow$ & focalização & apreensão \\
\hline modo de junção $\rightarrow$ & implicação & concessão \\
\hline
\end{tabular}

Fonte: Zilberberg (2007).

Os princípios da Semiótica Tensiva postulados por Zilberberg não excluem a Semiótica da linha francesa de J. Greimas. Ao contrário. Para Norma Discini (2015), a tensividade está presente em todos os patamares do percurso gerativo, desde o mais abstrato e abundante, nível fundamental, até o mais concreto, nível discursivo.

Zilberberg postula em sua teoria um sujeito entregue ao acontecimento surpreendente como alguém que é “atropelado" pelo próprio acontecimento extraordinário. Segundo nossa hipótese, o acontecimento sensível, com a surpresa que ele acarreta, encontra no riso o seu correlato, o exercício.

$\mathrm{O}$ acontecimento é de alta intensidade, pois repentinamente adentrou o campo de presença do sujeito de maneira abrupta e inesperada, portanto, também se caracteriza como de extensidade baixa. O exercício, ao contrário do acontecimento, é de baixa intensidade e de extensidade alongada. Ou seja, de andamento lento e maior temporalidade. $\mathrm{O}$ fato relatado no meme é, num segmento da existência experimentada, um acontecimento surpreendente, logo, aproxima-se do acontecimento extraordinário. Contudo, na medida em que se desenvolve a ironia e a sátira meméticas passamos, pelo menos na sua leitura, para o exercício. 
Ao incorporar o sensível ao estruturalismo da semiótica greimasiana, Claude Zilberberg oferece aparato teórico suficiente para analisar os discursos e eventos políticos vistos, muitas vezes, como acontecimentos pela surpresa que eles podem causar no enunciatário e como eles são percebidos e subvertidos pelo viés humorístico dos memes de internet.

\subsection{O perfil judicativo e a aspectualização}

Diana Barros (2016) fala sobre a construção do éthos dos sujeitos da política recente brasileira através de seus discursos exacerbados, que dão sinal verde para tolerar o intolerável. Assim como nos memes políticos, os enunciados são dirigidos a um público enunciatário previsto cuja aprovação dos discursos é traduzida em votos eleitorais em favor destes candidatos. De acordo com Barros (2016, p. 10)

[...] o sujeito político constrói-se, nesse caso, como um ator (ou como um éthos) intolerante de um tipo particular, pois elabora um discurso de "intolerância ou intolerável", segundo certos valores. [...] Os discursos do deputado [Jair Bolsonaro] e de outros políticos mostram que eles usam discursos considerados intolerantes e, em alguns casos, contrários à lei (racistas, por exemplo), para construir uma imagem de político intolerante ao que considera, assim como o seu partido e o seu eleitor, intolerável. A aprovação do destinatário, que atribui poder aos sujeitos políticos e em nome de quem eles falam e agem, aparece, por exemplo, na votação expressiva do deputado Bolsonaro, na eleição de 2010 [...] e, principalmente, na de 2014, em que obteve mais de 464 mil $\operatorname{votos}[\ldots]$.

Nessa nova forma do fazer-político, na qual se predomina a polêmica em lugar do diálogo, o jornalista e semioticista Clóvis Junqueira Saint-Clair (2018), em reportagem para a revista $E$ poca ${ }^{32}$, afirma que nessa forma de exacerbação do discurso "são as emoções que ditam as regras e tornam os discursos dos candidatos mais persuasivos". O intenso é da ordem do afeto, do estésico e do passional.

Entretanto, o olhar desacelerado e mais extenso para as coisas do mundo assegura a perceptibilidade para uma observação aparentemente mais objetiva, ou melhor dizendo, "garante clareza para a inteligibilidade do narrado". Esse modo de percepção apresenta uma distância emocional suficiente para que o sujeito possa olhar as coisas do mundo e

32 SAINT-CLAIR, Clóvis. O discurso e a exacerbação. Época. 25 de outubro de 2018. Disponível em: https://epoca.globo.com/o-discurso-a-exacerbacao-23182202. Acesso em 19 de fevereiro de 2020. 
ironizá-las (DISCINI, 2015, p. 60). O logos entendido como o próprio discurso enunciado também pode ser pensado como a razão do argumento. Logo, devido a sua inteligibilidade, "a estética da ironia e do humor subsidia a percepção que temporaliza as coisas do mundo na ordem daquilo que é mais lento" (ibid., p. 62).

Essa temporalização, andamento lento ou dinâmico, acelerado ou desacelerado, é entendida pela semiótica tensiva como aspectualização temporal. Para conseguir tal efeito de sentido do discurso, o enunciador projeta um observador que será o mediador do enunciador, e juntamente com o narrador, indicará, a partir de um ponto de vista por ele adotado, se o discurso apresentado possui aspecto incoativo (inicial), durativo ou terminativo. $\mathrm{O}$ meme pode ser pensado como gênero a partir dessas premissas teóricas.

Norma Discini (2015) fala do perfil judicativo do sujeito que julga e critica moralmente o "outro", deixando traços constituintes de um estilo e um éthos moralizante. Segundo a autora

O perfil social, que privilegia o olhar judicativo do sujeito [...] corrobora o julgamento feito sobre as coisas do mundo, conforme uma 'percepção ativa' que se fixa 'de uma vez por todas' em determinado juízo. Quanto mais é privilegiada a moralização 'do que está aí', mais somos levados pelo perfil social do éthos, mais vem à tona o entendimento que supõe responsabilidade e tomada de posição. Desse modo se sobressai o viés judicativo do olhar e, com ele, um sujeito mais agente no ato de enunciar (DISCINI, 2015, p. 68).

Esse perfil judicativo sobre o qual discute Discini converge para a figura do ator da enunciação visto no nível discursivo. Esse ator é constituído pelos papéis por ele assumido que lhe conferem "[...] identidade, estilo e corpo, preenchidos por crenças e valores, modos de ser e de fazer, decorrentes de papéis temáticos e figurativos" (BARROS, 2016).

Ao afirmarmos que enunciador do meme se caracteriza como um sujeito de perfil judicativo e aspecto télico (ou seja, com uma finalidade persuasiva), tal afirmação remete à aspectualização do ator que se revela moralizante, politizado, irônico e julgador pelo estilo que incorpora. De acordo com Discini, a respeito do observador instalado no discurso

O perfil moral ou ético, respaldo do sujeito performativo e responsável pelo ato de enunciar, supõe responsividade e tomada de decisão, bem como convicção e desejo de convencer. Esse perfil, desdobramento do conceito aristotélico de um éthos [...], marca a identidade estilística, ao supor a aspectualização actorial segundo um observador social, o que favorece a depreensão de papéis temáticos que semantizam o ator no 
nível discursivo [...]. O actante-observador, que viabiliza a aspectualização do ator, cumpre-se como sujeito cognitivo que, delegado pelo enunciador e por ele instalado no discurso enunciado conforme uma debreagem enunciativa, encarrega-se de um 'fazer receptivo' e de um 'fazer interpretativo', como salientam Greimas e Courtés (2008: 347-8): no primeiro caso, está o viés sensível da observação ou o observador sensível; no segundo, o viés judicativo da observação ou o observador social (DISCINI, 2015, p. 73-75) . $^{33}$.

O perfil judicativo do ator da enunciação, aquele que faz a crítica através dos memes, apresenta-se, segundo Discini (2015, p. 68), com valência mitigada pelo modo de julgar o mundo das coisas, com domínio do inteligível sobre o sensível, como podemos conferir no gráfico seguinte:

Figura 16 - Curva tensiva

Fato noticioso - Discurso polêmico (eixo da intensidade)

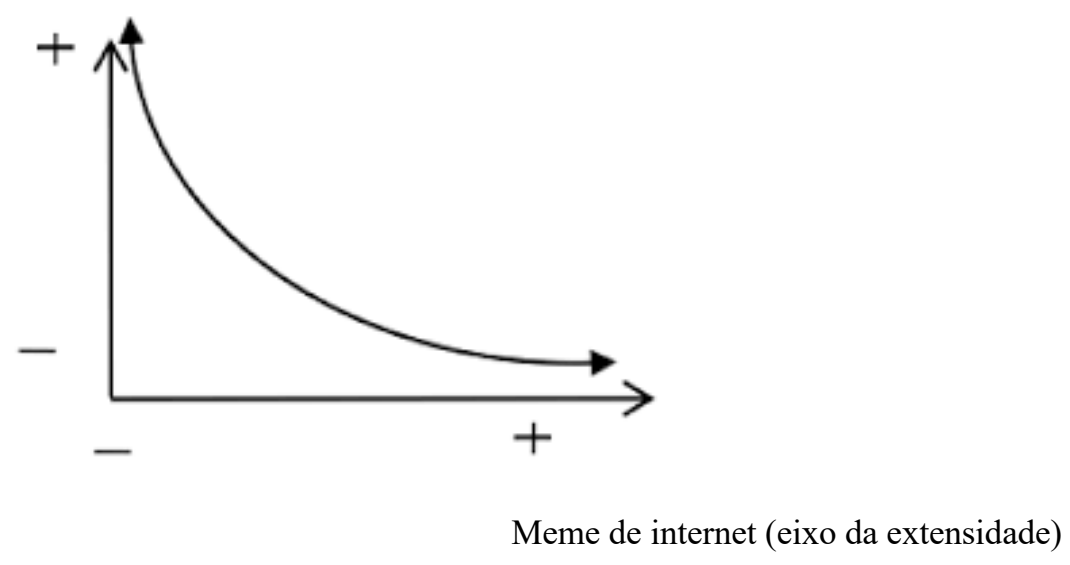

Fonte: elaboração própria.

De alta intensidade, esses acalorados discursos que são noticiados pela imprensa descem na curva do gráfico tensivo e vão do acontecimento ao exercício memético, onde chegam com uma força átona, de baixa intensidade, mitigada, mas aumentam a sintagmática da notícia e ganham maior extensividade, ou seja, faz o fato durar mais tempo pelas redes de relacionamento social pelo seu processo de compartilhamento.

Voltando à teoria aqui considerada paralela à semiótica, lembramos que para Bergson (2018, p. 100), rimos do que julgamos no outro um traço defeituoso ou de falta

${ }^{33}$ GREIMAS; COURTÉS. Dicionário de semiótica. Traduzido por Álvaro Dias Lima et al. São Paulo: Contexto, 2008. 
de sociabilidade. Marino (2018), a respeito dos memes, fala que o "erro" está presente no texto-base da elaboração do meme. Levaremos em consideração a maneira como o mundo enunciado se apresenta, seja a respeito das mulheres oprimidas pelo machismo ou o discurso de ódio contra as minorias no capítulo seguinte desta dissertação. Esse "erro" do qual fala Marino é "consertado" no meme, buscando atingir uma atenuação emocional do que é julgado como "absurdo" ou "intolerante" pelo viés humorístico. Se determinado discurso político não favorece o diálogo, o enunciador memético marca seu posicionamento, como observador social, diante da polêmica. 


\section{DEPREENSÕES TEÓRICO-ANALÍTICAS}

\subsection{Liberdade x opressão}

Pela forma como conduziu os trabalhos da Casa, parabéns, presidente Eduardo Cunha. [...] Pela família e pela inocência das crianças em sala de aula que o PT nunca teve. Contra o comunismo, pela nossa liberdade, contra o foro de São Paulo, pela memória do coronel Carlos Alberto Brilhante Ustra, o pavor de Dilma Rousseff. Pelo exército de Caxias, pelas nossas forças armadas, pelo Brasil acima de tudo e Deus acima de todos, o meu voto é sim" "34.

Deputado Jair Bolsonaro (PSL) em votação na Câmara dos Deputados a favor do processo de destituição da presidente Dilma Rousseff (2016)

Michel Temer (PMDB), no cargo de vice-presidente, era então o primeiro da linha sucessória para ocupar o cargo da presidente (2011-2016) a ser deposta Dilma Rousseff (PT). Após a votação no Congresso, findada na madrugada do dia 16 de abril de 2016, numa sessão com duração de aproximadamente nove horas, deu-se a abertura do processo de impeachment na Câmara dos Deputados, que seguiria mais tarde para o Senado, ato que culminaria no afastamento definitivo da então presidente e na sua substituição interina pelo vice Michel Temer. Dilma Rousseff era acusada de ter cometido pedaladas fiscais que, segundo o website do Senado ${ }^{35}$, significam o atraso voluntário de verbas para órgãos institucionais tais como o BNDES (Banco Nacional de Desenvolvimento Econômico e Social), Banco do Brasil e Caixa Econômica Federal para pagamento de programas sociais como Bolsa Família e Minha Casa Minha Vida. Os autores do pedido de impeachment, o jurista Miguel Reale Júnior e a professora de Direito da Universidade de São Paulo Janaina Paschoal, alegaram ter havido crime de responsabilidade fiscal por parte da presidência.

Dilma Rousseff só deixaria a presidência da República no dia 31 de agosto de 2016. Editoriais de imprensa, no entanto, já explicitavam serem a favor de sua saída muito antes do fim do processo. O Jornal Estadão estampou na edição digital do caderno

\footnotetext{
34 Vídeo Disponível no canal do jornal Estadão do YouTube. https://www.youtube.com/watch?v=xiAZn7bUC8A. Acesso em 29 de fevereiro de 2020.

35 Pedalada Fiscal. Senado Notícias. Disponível em: https://www12.senado.leg.br/noticias/entenda-oassunto/pedalada-fiscal. Acesso em 01 de março de 2020.
} 
Opinião do dia 07 de abril de 2016 a manchete "Impeachment é o melhor caminho". O jornal afirmava

Diante das incertezas provocadas pela grave crise política, econômica e moral que projeta gravíssimas consequências sociais sobre o País, uma coisa é absolutamente certa: do jeito que está não pode continuar. Este governo, inviabilizado por uma presidente da República inábil e inepta, se deslegitimou de facto por decisão da maioria absoluta dos brasileiros e precisa ser afastado o mais rapidamente possível para que se dê início à reconstrução nacional ${ }^{36}$.

A imagem da presidente apresentava desgaste através dos veículos de imprensa e com os seus eleitores. Os escândalos de corrupção apontados como responsabilidade de correligionários do Partido dos Trabalhadores (PT), o mensalão dentre deles, tampouco pareciam corroborar para a permanência de Dilma como chefe de Estado.

A revista Istoé do dia 06 de abril de 2016 apresentou a ex-presidente na capa com o título "As explosões nervosas da presidente", o que construía o simulacro de alguém incapaz de ocupar a presidência do país com a serenidade que o posto exige. Outras frases endereçadas a ela, na mesma publicação, foram "uma presidente fora de si", "perdeu as estribeiras", "os medicamentos nem sempre surtem efeito, atestam seus auxiliares" 37 , o que revelava um grande desgaste na imagem da representante maior do país.

Era mister que o novo governo, do sucessor Michel Temer, tivesse uma nova imagem. Sem os "descontroles" da então ocupante, essa nova imagem deveria ser mais serena a fim de passar a ideia de que o governo iminente seria apaziguador, contrapondose ao tumultuado e frágil momento pelo qual a democracia brasileira passava, e que obedecesse às palavras de ordem expressas tanto pelos deputados quanto por um público ávido por mudanças no sistema eleitoral, na votação que destituiu Dilma Rousseff: fé, família e bons costumes.

Marcela Temer, esposa de Temer, já havia chamado a atenção do público em 2011, quando mostrou uma grande beleza jovial na posse de Dilma e Temer no primeiro

\footnotetext{
36 Impeachment é o melhor caminho. Estadão. Opinião. 07 de abril de 2016. Disponível em: https://opiniao.estadao.com.br/noticias/geral,impeachment-e-o-melhor-caminho,10000025268. Acesso em 01 de março de 2020.

${ }^{37}$ PARDELLAS, Sérgio; BARGAMASCO, Débora. Uma presidente fora de si. Istoé. Brasil. 01 de abril de 2016. Disponível em: https://istoe.com.br/450027 UMA+PRESIDENTE+FORA+DE+SI/. Acesso em 01 de março de 2020 .
} 
dia do ano de $2011^{38}$. A futura primeira dama passou a ser conhecida do grande público a partir desse momento.

Dias depois da votação na Câmara, em 18 de abril de 2016, a revista Veja ${ }^{39}$, construiu um perfil da Marcela Temer já lhe atribuindo o predicado de "quase primeiradama" para promover a imagem do governo Temer, que se instalaria, com garantida certeza, segundo a imprensa, dentro de alguns meses.

Figura 17 - Reportagem Revista Veja

\section{Marcela Temer: bela, recatada e "do lar"}

A quase primeira-dama, 43 anos mais jovem que o marido, aparece pouco, gosta de vestidos na altura dos joelhos e sonha em ter mais um filho com o vice

Por Juliana Linhares - 18 abr 2016, $19 \mathrm{~h} 14$

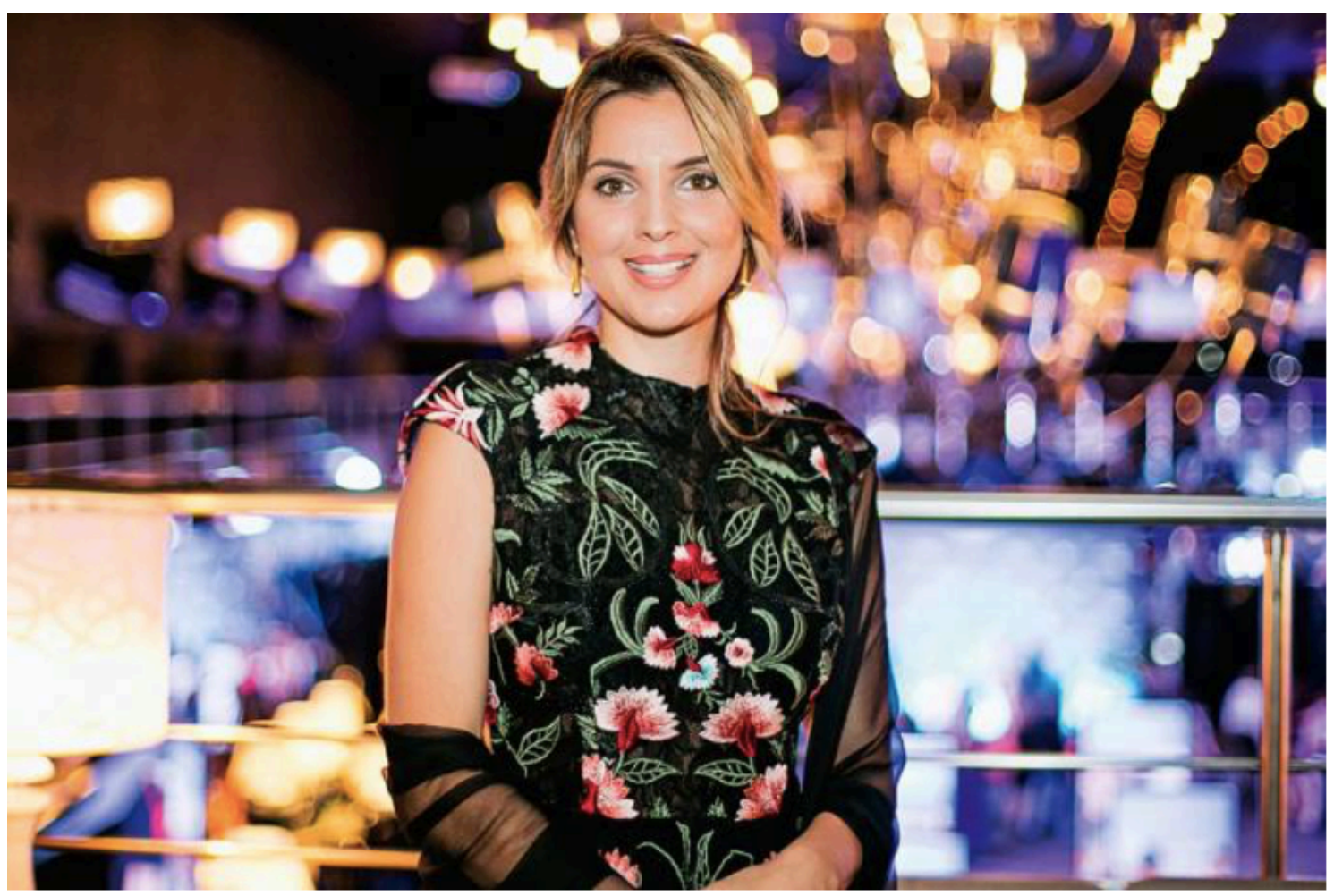

Fonte: Veja (2016).

38 PENTEADO, Lolo. O look de Marcela Temer na possa de Dilma. Extra. 08 de janeiro de 2011. Disponível em: https:/extra.globo.com/famosos/lolo-penteado/o-look-de-marcela-temer-na-posse-dedilma-818439.html. Acesso em 01 de março de 2020.

39 LINHARES, Juliana. Marcela Temer: bela, recatada e do lar. Veja. Brasil. 18 de abril de 2016. Disponível em: https://veja.abril.com.br/brasil/marcela-temer-bela-recatada-e-do-lar/. Acesso em $1 \mathrm{de}$ março de 2020. 
Na matéria citada, no seu plano da expressão (Figura 17), a imagem do ator, figurativizado por Marcela Temer, está centralizada, concentrada em primeiro plano. No segundo plano, o fundo está difuso, estratégia utilizada pelo enunciador para fixar a atenção do enunciatário apenas na imagem principal do ator. Suas vestes deixam transparecer pouco a pele. Vestido preto, com algumas flores estampadas, fechado até o pescoço e sem mostrar decote. Apenas um dos antebraços fíca à mostra. O outro está completamente coberto por um lenço preto transparente. $\mathrm{O}$ ator do enunciado aparece retraído, mostrando uma paixão de timidez. O título da reportagem era "Marcela Temer: bela, recatada e 'do lar'”.

Os anseios de reconstituição dos valores morais da família brasileira ganhavam agora "materialidade corporal" na figura de Marcela. O plano de expressão da imagem funciona como um prelúdio para um percurso eufórico do programa narrativo no plano do conteúdo do texto da reportagem sobre a futura primeira dama.

Apresentaremos a publicação da matéria na íntegra no Anexo $A$ desta dissertação para fazermos, a partir dela, as análises teóricas utilizando a Semiótica Discursiva.

\subsubsection{Análise semiótica da matéria}

O texto da reportagem é temática e figurativamente versado sobre a vida conjugal de Marcela e Temer. É a história de um casamento. Para Diana Barros (2002, p. 17), que retoma Greimas e Courtés (2012) no nível fundamental, o mais profundo e abstrato do percurso gerativo, apresentam-se as oposições dos termos semânticos, pois o sentido só é alcançado pelas oposições, quando se percebe a diferença. Nesse primeiro nível, as categorias semânticas a serem colocadas nos dois eixos, que possuem entre eles uma relação de contrariedade pressuposta, seriam /transgressão/ x /integração/. Logo, teríamos como seus contraditórios a /não-transgressão/ e a /não-integração/. A /transgressão/ diz respeito ao descumprimento do que é estabelecido por uma ordem, ao passo que a /integração/ é sobre a inclusão dentro das convenções sociais.

Essas categorias iniciais, no que diz respeito à reportagem, formam o arranjo básico que servirá como sustento da axiologia discursiva até o final. $\mathrm{O}$ texto se sustenta na oposição entre $S_{1} \times S_{2}$. A reportagem também apresenta a oposição entre /riqueza/ $\left(S_{1}\right)$ e /pobreza/ $\left(\mathrm{S}_{2}\right)$ - esta no nível discursivo, pois diz respeito aos temas. O texto da reportagem começa e termina de forma equivalente, dando um efeito de continuidade. Marcela e Temer são, respectivamente, um homem e uma mulher de sorte, sendo homem 
e mulher definições figurativas do nível discursivo, isto é, concretizações das oposições profundas /transgressão/ x /integração/.

Oposições fundamentais:

\section{/transgressão/ x /integração/ \\ /riqueza/ x /pobreza/ \\ /homem/ x /mulher/}

No nível narrativo, através da manipulação, reconhecemos que o sujeito Marcela é modalizado, tornando-se um sujeito de fazer. No nível discursivo se apresenta concretizado o sujeito de estado (Marcela). Nesse nível, como ator do enunciado, Marcela se apresenta como o sujeito que possui pouca experiência profissional e currículo pouco extenso; já foi miss por duas vezes, recepcionista, e é bacharel em direito sem nunca ter exercido a profissão. Esse sujeito na narratividade da reportagem entra em conjunção com os valores axiológicos depositados no objeto de valor casamento. Esse sujeito entra nessa conjunção pelo fazer persuasivo do destinador-manipulador $\left(\mathrm{S}_{1}\right)$, Michel Temer, para poder se tornar "vice-presidente do lar". Consideramos essa manipulação implícita.

Segundo a narratividade da reportagem, para que o sujeito de estado se torne sujeito do fazer, ou seja, o sujeito da performance, é preciso haver uma transformação. Para isso, Marcela, o sujeito narrativo em pauta, precisa obter competência para adquirir o objeto de valor que almeja. A manipulação implícita ocorrida é por sedução, visto que a integração e o casamento são axiologizados positivamente pelo destinador e pelo destinatário. O papel de adjuvante cabe à mãe "[...] que acompanhou a filha adolescente em seu primeiro encontro com Temer". A competência modal é de paixão simples de desejo: desperta no sujeito um /querer-ser/, um /poder-ser/ e um /saber-ser/. Tem que ser prendada e saber/querer cuidar da casa, do marido, do filho. A diferença de idade “[Marcela é] 43 anos mais jovem”, seria um obstáculo para que a performance do sujeito não ocorresse, de acordo com os valores ideológicos (nível discursivo) de nossa sociedade. Mas tal obstáculo é superado pelas qualidades intrínsecas a Marcela: tímida e do lar. Tanto o sujeito de estado quanto o sujeito de fazer, pensados ambos no amparo do ator do enunciado, Marcela, são actantes diferentes dentro da cena narrativa. Esses papéis do nível narrativo são desempenhados, neste caso, pelo mesmo ator no nível discursivo.

"Marcela é uma mulher de sorte", assim afirma a reportagem logo na abertura do texto. Aqui entramos na manipulação enunciativa: a revista, o repórter e narrador são os 
destinadores-julgadores implícitos, que fazem a sanção "de sorte". A sanção e a sua avaliação são realizadas logo no começo pelo destinador-julgador, que é o próprio enunciador do texto (a revista Veja). Mas aí está uma ironia que perpassa, ainda que sutilmente, a reportagem.

Voltando à narratividade, vemos que toda narrativa trilha um caminho lógico ao longo do qual as transformações dos estados, entre o ser e o fazer, se desenrolam. Lembremos que o sentido é processo de adensamento gradual (SARAIVA; LEITE, 2017, p. 44) do mais abstrato ao mais complexo e concreto. A sequência textual não precisa ser apresentada de maneira linear igual aos contos maravilhosos. Em outras linguagens, como o cinema, para dar um exemplo, as categorias do nível narrativo estão todas presentes, mas são apresentadas em outra ordem. O enunciatário vai aos poucos buscando quem são finalmente os sujeitos competentes, qual a performance e a sanção e, assim, vai preenchendo os espaços sintáticos que não foram apresentados de antemão. Voltando ao nosso corpus, a sanção final do sujeito realizado, mostrada logo no início, é aparentemente positiva, uma vez que a "princesa" consegue se casar, como em toda jornada do herói, com seu "príncipe encantado" 43 anos mais velho. Dizemos "aparentemente" porque fica a voz tênue da ironia da enunciação.

Saraiva e Leite esclarecem, sobre o modelo canônico narrativo

Quando tratamos do esquema narrativo canônico, um ponto deve ficar claro. Por um lado, suas fases [...] refletem antes um ordenamento lógico-semântico do que a sequência textual propriamente dita, pois sempre é possível imaginar textos que comecem por uma sanção. Basta lembrarmos os tantos filmes que começam com o sujeito saindo de uma penitenciária. Logo nos perguntamos pela performance sancionada. Se o filme é investigativo, a questão é identificar o responsável pela performance, buscando quem /sabia/ e /podia/ realizá-la. Uma vez identificados os sujeitos competentes, os suspeitos, o passo seguinte é conhecer as razões motivadoras da performance, os motivos que poderiam levar um dos sujeitos competentes a /querer/ ou a /dever/ realizá-la (2017, p. 55-56).

Na sintaxe discursiva, a falta de pronomes pessoais de primeira e segunda pessoa e dêiticos que remetam ao "aqui" e o "agora" nos enunciados cria um efeito de objetividade e de afastamento. Trata-se de debreagens enuncivas nas quais se instalam, nas instâncias de pessoa, tempo e lugar, um "ele", um "então" e um "alhures".

Em nenhum momento o texto faz alusão a um “eu” no discurso. Nos trechos em que as figuras de outros atores são inseridas, como o cabelereiro, a estilista e os amigos de Temer, eles surgem na cena enunciada pelo narrador e considerada enunciativa na 
sintaxe discursiva para dar depoimentos lisonjeiros a respeito das figuras centrais da reportagem, que são Michel e Marcela Temer. Mas são enunciadores de segundo grau. Assim se constrói um simulacro factual dos atores do enunciado, e factual pois dizem respeito ao fato noticioso.

Numa debreagem interna, vozes delegadas pelo enunciador, o primeiro que aparece, o cabelereiro, afirma que Marcela "[...] pedia luzes bem fininhas e era 'educadíssima' [...] 'tem tudo para se tornar a nossa Grace Kelly”'. Os verbos no pretérito imperfeito marcam um aspecto durativo, de um hábito de longa duração em algum lugar no passado, provando ter sido frequentadora de bons endereços requintados, o alhures, como o salão de "clientela estrelada". Fazendo uma debreagem interna na figura da estilista, em discurso direto, a reportagem acrescenta que "Ela gosta de vestido até o joelho e de cores claras".

Fiorin (2016b) fala que essas debreagens internas são responsáveis por oferecer um efeito de sentido de verdade, distanciando o enunciador dos atores do enunciado no momento em que o primeiro instala uma debreagem enunciva. Segundo Fiorin

[...] as debreagens internas são responsáveis pela produção de simulacros de diálogos no texto, pois estabelecem interlocutores, ao dar a voz a atores já inscritos no discurso. A debreagem de segundo grau cria a unidade discursiva denominada discurso direto e cria um efeito de sentido de verdade. Com efeito, o discurso direto proporciona ao enunciatário a ilusão de ouvir o outro, ou seja, suas "verdadeiras palavras" (idem, p. 67).

O tema da solenidade matrimonial figurativizado no casamento de Temer e de Marcela é construído sobre a isotopia figurativa, para a mulher-esposa, de uma pessoa "discreta" ("Em todos esses anos de atuação política do marido, apareceu em público pouquíssimas vezes"), "educadíssima", como fora salientado previamente. No tema beleza, temos a figura da "ex-miss". A matéria compõe o simulacro de integração conjugal feminina aos valores masculinos, aqui euforizados, pela relação sintagmática com as figuras "vestidos até o joelho", "cabelo preso", "cuidar da pele", "cuidar da casa", "trazer e levar Michelzinho na escola".

Porém, há também a figura da mulher carnal, que garante satisfação ao homem com quem se casou. O final da matéria traz um trecho de um poema escrito por Temer dedicado à companheira. A esposa é relacionada ao sexo pelas imagens "De vermelho / Flamejante/ Labaredas de fogo/ Olhos brilhantes/ Que sorriem /Com lábios rubros/ Incêndios". 
O marido, o oposto semântico do termo mulher, também se mostra euforizado no texto. Sendo assim, o sexo masculino está ligado ao ideal de integração, dêixis positiva, em oposição ao de transgressão, aqui presente como dêixis negativa. No texto-reportagem encontram-se dois percursos narrativos possíveis. O PN do sujeito actancial Michel Temer, no papel de auto destinador, está conjunto com o objeto de valor casamento como valor do bem, também de sanção positiva: "Michel Temer é um homem de sorte", diz a matéria. A figurativização do homem encarnado no papel do ator do enunciado Michel Temer, segundo informam "seus amigos", diz a reportagem, "toma vinho", "fuma charuto", tem um dia de trabalho "extenuante".

O enunciador lança mão de duas debreagens enuncivas para começar e finalizar o texto: "Marcela é uma mulher de sorte" e "Michel Temer é um homem de sorte". Contudo, os demais elementos que se conectam ao tema central "sorte" são diferentes.

A suposta sorte de Marcela é vinculada pelo amor que ainda não "arrefeceu" mesmo depois de doze anos de vida conjugal. O enunciador continua no desencadear da isotopia figurativa do romance "não arrefecido" citando um encontro que tiveram "Há cerca de oito meses [...] na sala especial do sofisticado, caro e badalado restaurante Antiquarius, em São Paulo". "Mi” e "Mar" passaram “[...] algumas horas de jantar romântico sob um céu estrelado" que não sofreu abalo "nem com a convulsão política que vive o país".

A sequência figurativa provocada pelo lexema "sorte" para Temer, ao seu turno, está atrelada tematicamente à paixão carnal, ao sexo, como consta nos versos do poema de Temer presentes dentro do texto reportagem "(Incêndios). "Tomam conta de mim / Minha mente / Minha alma / Tudo meu / Em brasas / Meu corpo / Incendiado / Consumido / Dissolvido / Finalmente / Restam cinzas / Que espalho na cama / Para dormir”. O texto chega ao fim com "Temer é um homem de sorte".

Segue abaixo a tabela correspondente à relação dos temas e das figuras depreendidos do texto da reportagem: 
Figura 18 - Temas e Figuras da reportagem "Bela, recatada e do lar"

\begin{tabular}{|c|c|c|c|c|}
\hline Temas & Casamento & Beleza & Sexo & \\
\hline \multirow[t]{2}{*}{$\begin{array}{l}\text { Figuras e } \\
\text { textualização } \\
\text { das figuras }\end{array}$} & $\begin{array}{l}\text { Vestidos até o } \\
\text { joelho; cabelo } \\
\text { preso; } \\
\text { recatada; } \\
\text { educadíssima; } \\
\text { discreta; } \\
\text { mulher de } \\
\text { sorte; cuidar da } \\
\text { pele; trazer e } \\
\text { levar filho para } \\
\text { escola; do lar; } \\
\text { não exercer } \\
\text { uma função } \\
\text { empregatícia; } \\
\text { submissa }\end{array}$ & $\begin{array}{l}\text { Participou do } \\
\text { concurso de } \\
\text { miss; luzes } \\
\text { "fininhas"; } \\
\text { semelhança } \\
\text { com a atriz } \\
\text { Grace Kelly }\end{array}$ & $\begin{array}{l}\text { Olhos } \\
\text { brilhantes, } \\
\text { labaredas de } \\
\text { fogo; } \\
\text { flamejante, } \\
\text { incêndios; } \\
\text { pessoa que } \\
\text { providencia o } \\
\text { prazer }\end{array}$ & Mulher \\
\hline & $\begin{array}{l}\text { Trabalho } \\
\text { extenuante; } \\
\text { toma vinho e } \\
\text { fuma charuto; } \\
\text { provedor }\end{array}$ & & $\begin{array}{l}\text { Corpo, alma e } \\
\text { mente } \\
\text { incendiados; } \\
\text { em brasas; } \\
\text { consumido; } \\
\text { dissolvido; em } \\
\text { cinzas; para } \\
\text { dormir; aquele } \\
\text { que recebe o } \\
\text { prazer; }\end{array}$ & Homem \\
\hline
\end{tabular}

Fonte: elaboração nossa.

A publicação se refere em duas ocasiões ao momento histórico brasileiro do impeachment. Além da que já mencionamos, a concessão feita pelo ator do enunciado de querer sair para um jantar apesar de estar no epicentro de uma convulsão política, a outra surge quando Marcela Temer pensou que estava grávida, mas era "alarme falso". Quem nos dá o parecer é "tia Nina, irmã da mãe da Marcela", também em discurso direto, que diz " [...] não teria sido mesmo um bom momento para ela engravidar, dada a confusão do país", com ancoragem no real, dando efeito de credibilidade para o enunciatário-leitor. A figurativização isotópica do momento, que chamaremos, na falta de uma melhor definição, de "crise", cria o contexto. A então situação do país era disforizada pela revista. Marcela seria a nova mulher, da nova política, com costumes antiquados, símbolo ideal, portanto, para marcar uma nova era. 
As estruturas semio-narrativas (nível fundamental e narrativo) fornecem as bases axiológicas do texto que vão ser concretizadas pelos temas e figuras do texto, que indicam a orientação ideológica do enunciador.

Ter o segmento visual confere ao texto verbal um efeito icônico e persuasivo de simulacro sensível do mundo narrado. A figurativização da "bela, recatada e do lar" na expressão se homologa com as figuras discursivas trazidas pelo conteúdo.

O enunciador da reportagem, Veja, se posicionava contra o então governo do PT. O periódico semanal, guardando relações contíguas a um jornal de notícias diárias, tem um público específico que o lê regularmente e com quem, além de uma preferência e uma prática habitual, cria uma relação de identificação.

Desse modo, o enunciatário-leitor é mobilizado, através das estratégias persuasivas, por um crer que antecede o saber, pela relação que beira o íntimo, através das práticas que o enunciador-revista possui com o enunciatário-leitor. Pelo regime de crença, a saída da presidente do PT, o anseio pelo novo e, por conseguinte, uma nova figura feminina no Planalto (que não seja "nervosa", nem "explosiva" e que seja subserviente à figura masculina) eram então imperativos.

\subsubsection{Memes \#belarecatadaedolar}

A imagem de "mulher-perfeita" de Marcela Temer foi achincalhada na internet quase que concomitantemente à publicação da revista, através de memes de internet seguidos da hashtag \#belarecatadaedolar.

As imagens de mulheres bebendo em bares, com pouca roupa, simulando atos sensuais e se divertindo demonstram que elas não estavam sendo representadas de forma justa pelo lema "bela, recatada e do lar" proposto pela reportagem da revista Veja. Ao contrário. O objetivo, além de criticar e ironizar, era acentuar uma outra realidade distante que o aparente viés conservador do enunciador Veja deixou implícito: a misoginia.

Segundo o jornal RFI Brasil, "o Brasil é um país extremamente machista" ${ }^{40}$. Em 2012 foram 4719 mulheres mortas, na maioria das vezes pelo próprio marido ${ }^{41}$. A

\footnotetext{
${ }^{40}$ FRANCO, Daniella. Site francês elogia mobilização feminista das brasileiras na internet. RFI. Brasil 03 de maio de 2016. Disponível em: http://www.rfi.fr/br/brasil/20160503-site-frances-elogia-mobilizacaofeminista-das-brasileiras-na-internet. Acesso em 5 de março de 2020.

${ }^{41}$ ALBERTINI, Jean Mathieu. "Belle, reservée et femme au foyer": les brésiliennes se rebellent contre le facisme. Rue 89. Jet Lag. 03 de maio de 2016. Disponível em: https://www.nouvelobs.com/rue89/rue89jetlag/20160503.RUE2810/belle-reservee-et-femme-au-foyer-les-bresiliennes-se-rebellent-contre-lemachisme.html. Acesso em 05 de março de 2020.
} 
publicação francesa Rue89 discute o movimento em torno da hashtag do meme jogando luz sobre outros fatos ocorridos no país que sustentam a afirmação de se tratar, de fato, de uma nação possuidora de valores axiologicamente euforizados do chauvinismo masculino.

A própria presidente Dilma foi visivelmente vítima de misoginia. Um adesivo que podia ser comprado pela internet mostrava a presidente de pernas abertas (Figura 19) para ser posicionado no carro na entrada do tanque de gasolina. Em campanha pró impeachment na cidade do Recife em 2016, era possível ler em um dos cartazes que acompanhavam os trios elétricos do cortejo político "balança que essa quenga cai" (Figura 20).

Figura 19 - "Adesivo para carros"

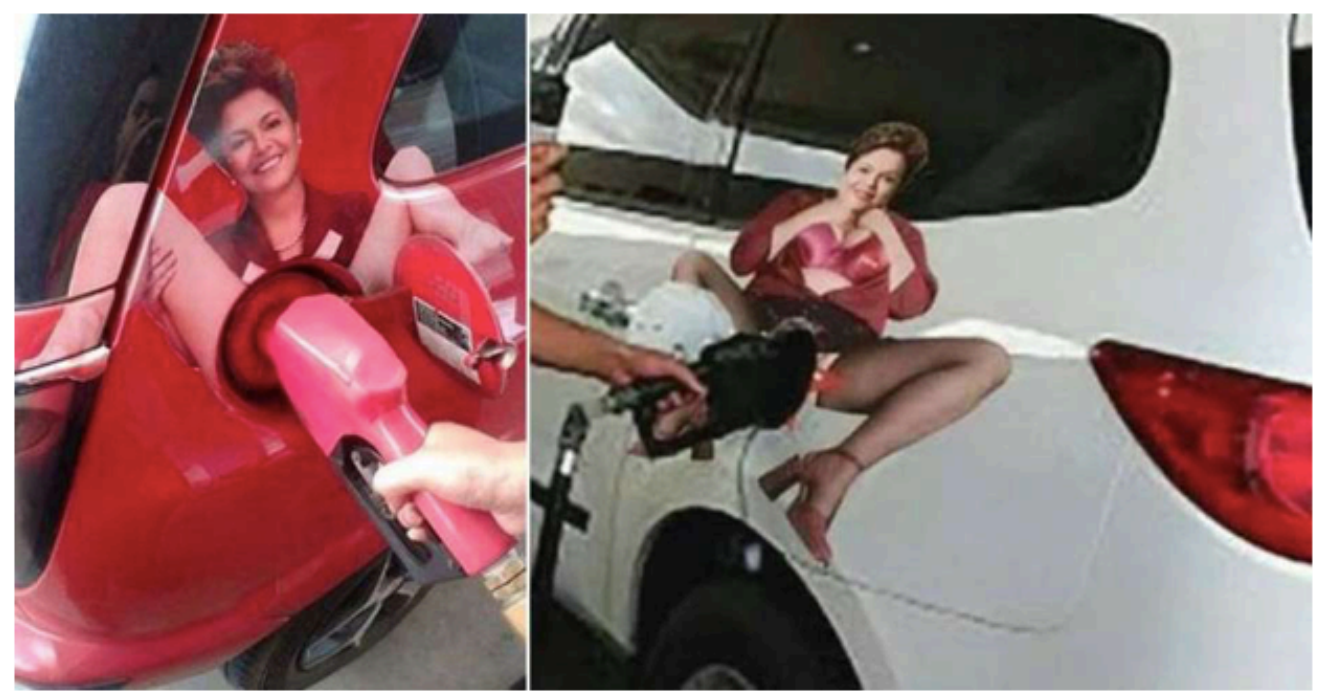

Fonte: https://www.terra.com.br/noticias/brasil/governo-denuncia-adesivo-com-ofensa-sexual-adilma,33f5fa7ff225c4a3d42f654bee769de9sgleRCRD.html. Acesso em 06 de março de 2020. 


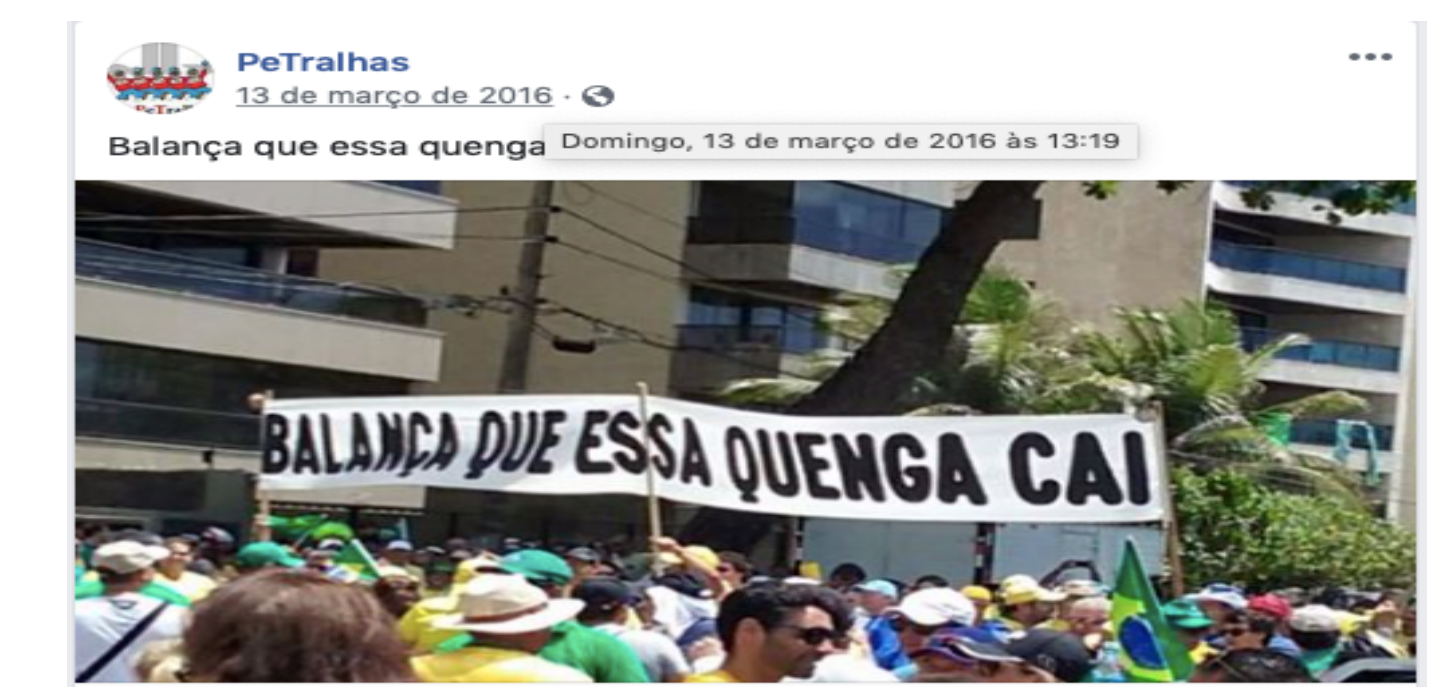

Fonte: https:/www.facebook.com/ospetralhas/photos/balança-que-essa-quenga-cai!/634255250045951/. Acesso em 06 de março de 2020.

A mobilização atingida através dos memes levou a um debate importante e sem precedentes na cultura digital brasileira. O "absurdo" da formulação axiológica de que uma mulher deva ser "bela e recatada" para não chamar muito a atenção masculina era debochado nas figuras dos memes. A crítica ao machismo, ou à representação dele na tríade "bela", "recatada" e "do lar", era a maior finalidade dos memes. Por essa razão, a oposição de base do nível fundamental encontrada nos memes será /liberdade/ $\mathrm{x}$ /opressão/.

Figura 21 - Meme "Beyoncé"

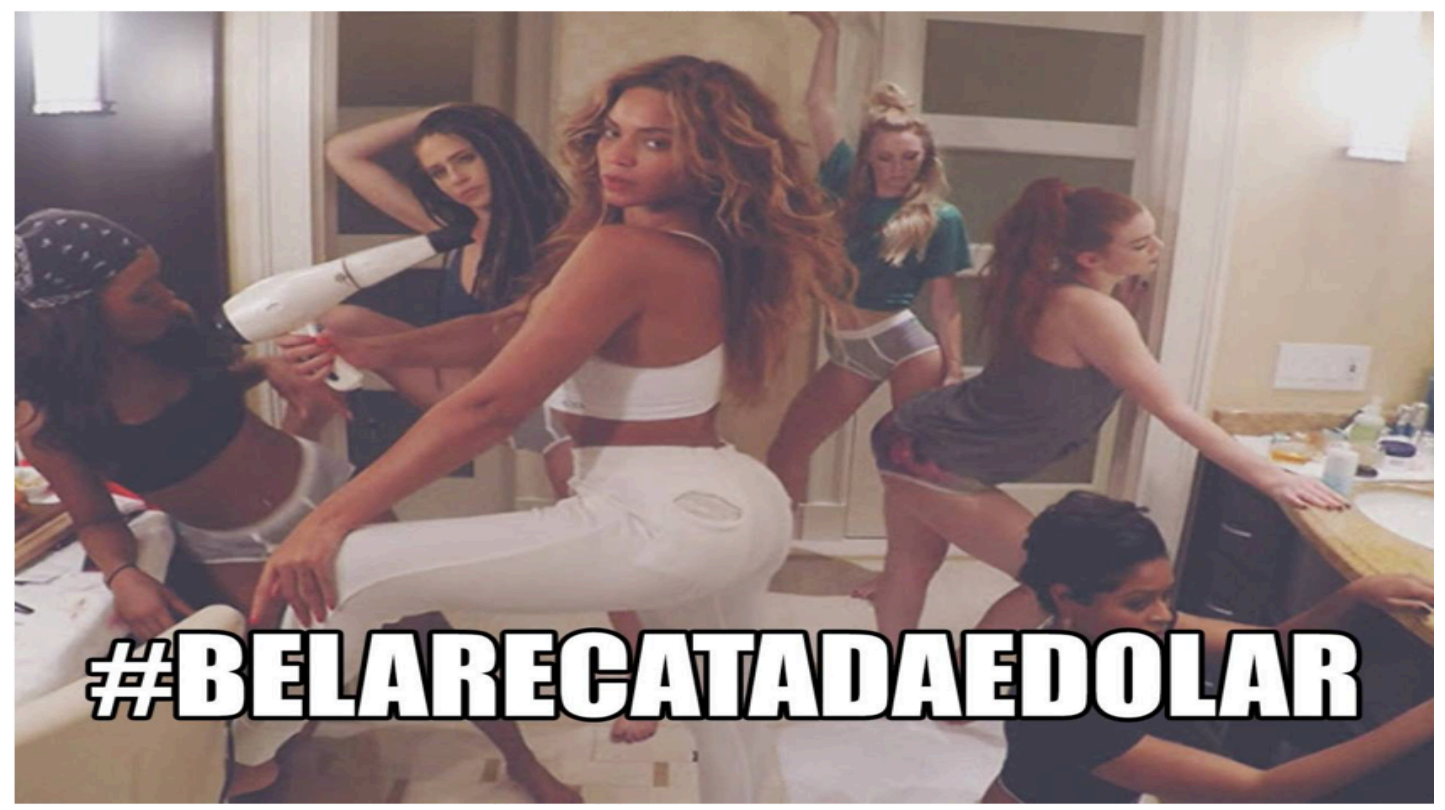

Fonte: https://meusmoinhos.tumblr.com/post/143117772297. Acesso em 03 de março de 2020. 
$\mathrm{Na}$ relação de complementaridade do quadrado (Figura 22), a não-liberdade implica em opressão, assim como a não-opressão implica em liberdade. Na contradição, por sua vez, os termos semânticos liberdade e não-liberdade são excludentes entre si.

O quadrado semiótico relativo aos memes está organizado desta maneira:

Figura 22 - Quadrado Semiótico Liberdade x Opressão

Liberdade Opressão

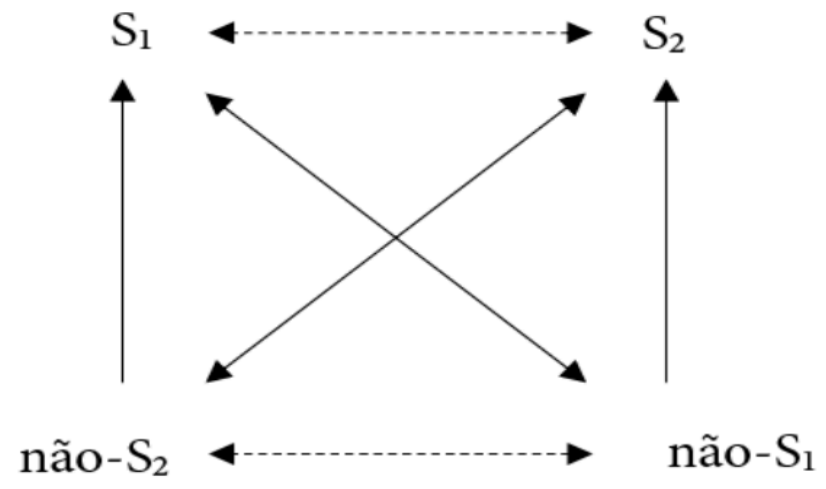

Não-opressão

Não-liberdade

Fonte: elaboração nossa.

Os termos semânticos /liberdade/ e /opressão/ sofreram, contudo, uma subversão no eixo dos dêiticos. A liberdade é apresentada de maneira euforizada, enquanto a opressão é disforizada.

$\mathrm{Na}$ Figura 21, "Meme Beyoncé", no seu segmento visual, nosso olhar foi convidado para a disposição topográfica das figuras no texto visual. $\mathrm{O}$ ator do enunciado, figurativizado pela cantora Beyoncé, não está retraído. Apresenta-se com o seu derrière levantado, fazendo uma pose mais sensualizada. Seus olhos estão virados para o público, enunciatário do texto. Recria o mesmo efeito de sentido de aproximação de uma enunciação em segundo grau, na qual o enunciador do texto meme deixa implícito o seu "eu" através da delegação de vozes ao ator do enunciado pelo narrador. 
No programa narrativo de base do meme, há um enunciador memético que manipulou o enunciatário do meme a entrar em conjunção com os valores por ele propostos. Esses valores do enunciador memético, ligados às pulsões naturais de liberdade, disforizam o discurso da revista Veja de que a mulher deveria ser submissa à figura masculina. Contudo, o enunciatário lê o que está implícito no meme, que é a ironia. O enunciador levou o enunciatário a criticar o conteúdo da reportagem.

A respeito dos memes, Fechine (2018), apoiada pelos estudos dos regimes de interação de Landowski (2014), afirma que sob o regime do ajustamento, um actante não planeja nem controla o que resulta da sua interação com o outro (ibid., p. 13).

Para a semioticista, o gesto de um convida ao gesto correlativo do outro, deixando-se conduzir pelo movimento criativo do outro e assim reciprocamente (idem, ibidem). A autora denomina esse tipo de meme de recriações.

O reconhecimento da forma derivada (ou recriada) como parte de uma mesma órbita de sentido que o texto-base é o jogo intertextual que mobiliza o saber enciclopédico dos usuários. Segundo Fechine

[...] tal reconhecimento supõe que se saiba o que foi imitado anteriormente caso contrário, não seria possível detectar ajustes subsequentes. Não é por acaso que as recriações costumam usar expressões paródicas. De fato, esta é a maneira mais fácil de estabelecer uma distinção e uma aproximação com relação ao tópico discursivo, uma vez que a paródia a subverte, mantendo-a como referência. (2018, p. 13$).{ }^{42}$

Nos memes da cadeia memética \#belarecatadaedolar, pressupõe-se que o enunciatário conheça a referência, o texto-base reportagem. Tratando-se os memes de textos alusivos à paródia, eles podem ter formas diferentes um do outro, uma vez que a paródia memética subverte, porém se mantém atrelada à referência do texto-base ou a associação ao sentido por parte do enunciatário-leitor não seria possível.

\footnotetext{
42 Do original “[...] telle reconnaissance suppose que l'on sache ce qui a fait précédemment l'objet d'une imitation, faute de quoi il ne serait pas possible d'en déceler les ajustements ultérieurs. Ce n'est pas par hasard si les récréations recourent si souvent à des expressions parodiques. De fait, c'est là le moyen le plus facile d'établir à la fois une distanciation et un rapprochement par rapport au topique discursif, puisque la parodie le subvertit tout en le conservant comme sa référence". Tradução nossa.
} 
Figura 23 - Meme "Bela, recatada e fumante"

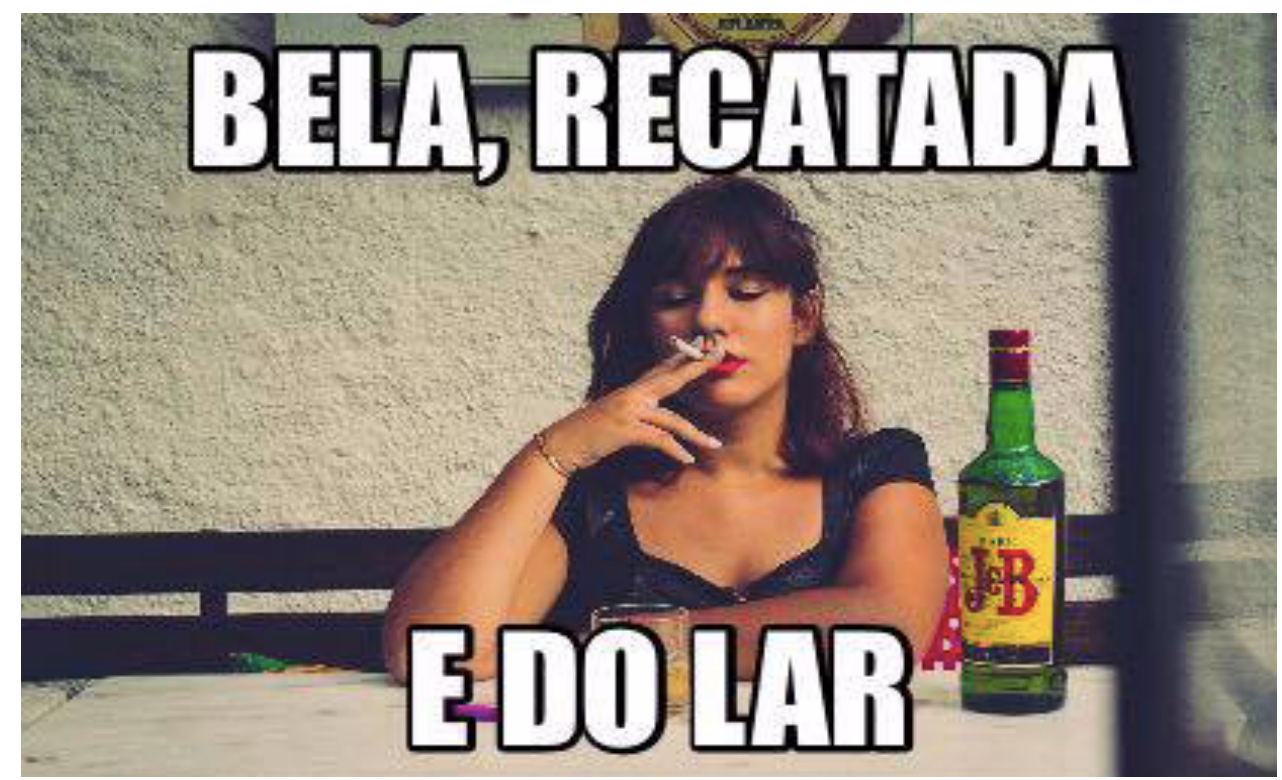

Fonte: http://superela.com/wp-

content/uploads/2016/04/12994289_493817797410125_6957049334290010646_n.jpg. Acesso em 03 de março de 2020 .

No meme da Figura 23, o ator do enunciado apresenta-se semanticamente preenchido por uma mulher sentada, fumando, com uma garrafa de whisky ao seu lado. Assim como a figura de Marcela Temer, a do ator do enunciado do meme só é mostrada do busto para cima. Os braços, se compararmos ao texto visual de base, apresentam-se desnudos e com decote à mostra. Este ator não está mais olhando diretamente para o enunciatário. O segmento verbal, presente em todas as variações meméticas, acaba indicando o oposto do que foi apresentado pelo segmento visual. A ironia ocorreu na incongruência entre o visual e o verbal. Os olhos fechados do ator retratado no meme fazem emergir o seu perfil judicativo: ele reprova o conceito da "mulher perfeita e prendada".

De certa forma, o enunciador, através do narrador que delega voz ao personagem, julgou negativamente os valores de submissão. Logo, o ator do enunciado, que é uma voz delegada por esse narrador, modalizou o enunciatário do meme a dever ou querer cessar ação ou a propagação de valores semelhantes. 


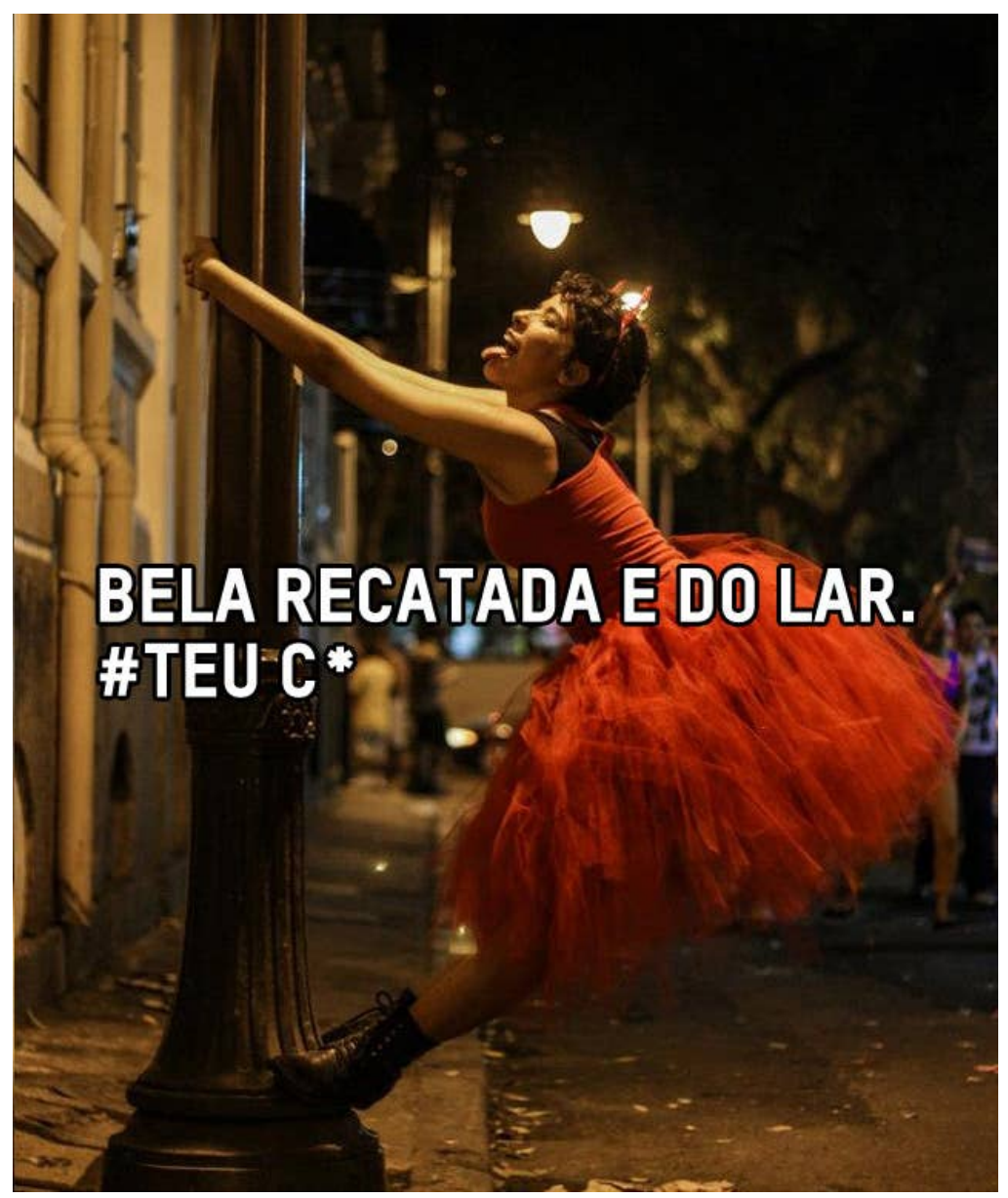

Fonte: https://img.buzzfeed.com/buzzfeed-static/static/2016-04/20/16/enhanced/webdr13/original-247781461184155-1.jpg?downsize $=700 \% 3 \mathrm{~A} \% 2 \mathrm{~A} \&$ output-quality=auto\&output-format=auto. Acesso em 03 de março de 2020.

$\mathrm{Na}$ Figura 24, o ator do enunciado apresenta-se figurativizado por uma mulher de vestido vermelho e tiara de chifres também vermelha. Ela ocupa todo o centro do segmento visual. Ela não está posando de frente como a então futura primeira dama, mas está de lado, língua para fora, dependurada num poste. Vê-se todo o seu corpo. O segmento verbal está sobreposto à sua imagem. No fundo, a imagem está desfocada, dando atenção à ação do ator do enunciado, que ocorre em primeiro plano. Pela enunciação sincrética, é possível observar sua semelhança com o texto-base, porém, por se tratar de uma intertextualidade irônica, algumas modificações foram feitas para obter o efeito humorístico.

Tal ironia é também encontrada nos memes precedentes (Figuras 21, 23 e 24). Mariana Luz Pessoa de Barros (2018), a respeito dos memes com conteúdo irônico, aponta que se reconhece a ironia no eixo da extensão, da razão, um significado que tem 
o seu valor invertido contendo o sentido e seu oposto (BARROS, 2018, p. 508). Os segmentos visuais afirmam o contrário, ou melhor, negam o que está marcado pelo verbo.

Transformar o "absurdo" do machismo em memes requer uma atenuação emocional da intensidade do fato noticiado, que teve alto impacto ligado à ordem do acontecimento (ZILBERBERG, 2011) e do sensível, mas que foi perdendo força para se instalar no eixo da inteligibilidade, do exercício, da ordem da razão pelo humor. O leitor do meme, ao chegar num grande impacto pelo segmento visual, logo, da ordem do sensível, começa a descender em sentido oposto. Em aparência, seria quase como se houvesse uma banalização do tema machismo e da luta feminina, porém o efeito de sentido alcançado com o meme parece ser o contrário. Em realidade, entre os memes e o mundo noticioso houve uma relação inversa (idem, ibidem). Os memes se estenderam na temporalidade e na extensibilidade a fim de instituir a crítica social, mantendo-a em alta.

Os temas abordados e as figuras que lhes dão preenchimento semântico subvertem essa imagem feminina de paixão de timidez como na foto de Marcela Temer e passam o efeito de sentido de estarem em liberdade, em oposição ao discurso da Revista Veja.

Em suas análises sobre os sentidos da tortura, Mariana Luz de Barros (2019, p. 501) afirma que a propagação dos memes contribui para o efeito de atenuação do impacto, do acontecimento segundo os estudos de Zilberberg (2011) "[...] Este é um dos efeitos possíveis da repetição [...]: reduzir intensidade". O que o enunciador memético fez em torno da hashtag \#belarecatadaedolar foi tornar o machismo um assunto recorrente e discutido. O riso e o cômico, comprovando a nossa hipótese inicial, desempenharam um papel importante na distribuição capilar dos memes pelas redes sociais. A apresentação debochada e irônica como o enunciado sincrético memético faz o meme entrar no campo de presença do enunciatário com maior rapidez.

Pelos desdobramentos tensivos (ZILBERBERG; FONTANILLE, 2001), tivemos a aceleração da leitura, que ocorreu por catálise. Para isso, o texto visual, aquele visto em primeiro plano pelo enunciatário, entrou no campo perceptivo rapidamente. A catálise, para Greimas e Courtés

[...] é a explicitação de elementos elípticos ausentes na estrutura de superfície. É um procedimento que se realiza com o auxílio dos elementos contextuais manifestados e mediante as relações de pressuposição que entretêm com os elementos implícitos. Desse modo, retomando o exemplo de $\mathrm{L}$. Hjelmslev, que propôs o termo, a proposição latina sine pressupõe um ablativo e não inversamente: tratase da 'interpolação de uma causa a partir da sua consequência', o que se tornou possível 'em virtude do princípio de generalização'. O mesmo 
procedimento da catálise pode ser aplicado à análise do discurso narrativo [...] e à análise semântica do discurso $(2012$, p. 54).

O que os semioticistas explicaram é que a catálise é a inferência que se faz a partir do que não está explicitamente manifestado pelo texto. A catálise faz o direcionamento da leitura, controla o acesso do sujeito ao campo de presença, e as elipses colaboram para essa aceleração do andamento. A leitura então é feita a partir dos elementos que estão nele implícitos. São as elipses que são preenchidas pelo enunciatário a fim de se constatar a ironia construída no discurso do próprio meme, dada pelo contraste entre o visual e o verbal. Já a crítica ao texto-base é dada pela intertextualidade com os memes.

Figura 25 - Meme "Belo, recatado e do lar"

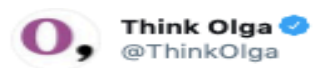

Rainha Elizabeth, uma mulher de sorte! Revista @VEJA , seja menas, porque nós somos muito mais do que você pensa!

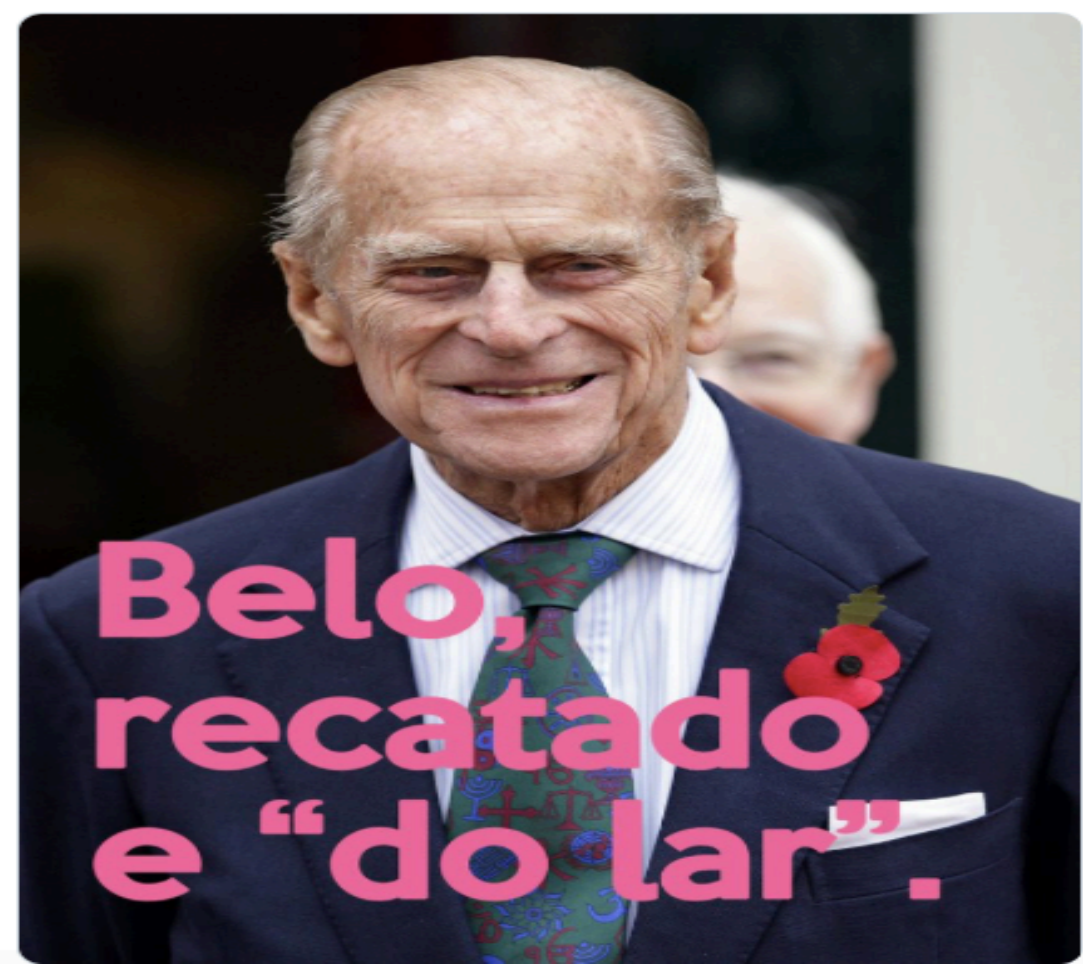

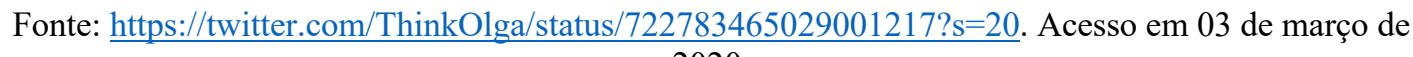
2020.

O coletivo feminino ThinkOlga criticou abertamente o teor da reportagem da Veja. Estampou o tuíte (Figura 25) "Rainha Elizabeth é uma mulher de sorte", também iluminando o interdiscurso com a reportagem da revista. $\mathrm{O}$ interdiscurso, como sabemos, está sempre habitando o discurso. No caso, o interdiscurso foi iluminado e favoreceu a 
intertextualidade no segmento verbal. O meme veiculado no tuíte também tinha no texto visual o "belo, recatado e do lar", tendo como figura deste papel temático o príncipe Filipe, duque de Edimburgo, marido da Rainha Elizabeth da Inglaterra. No final, a seguinte mensagem "Revista Veja, seja menas, porque nós somos muito mais do que você pensa", declarou o coletivo como forma de repúdio.

A própria presidente Dilma Rousseff também se transformou em personagem de um meme com a mesma hashtag, conforme a Figura 26.

Figura 26 - Meme "Dilma recatada"

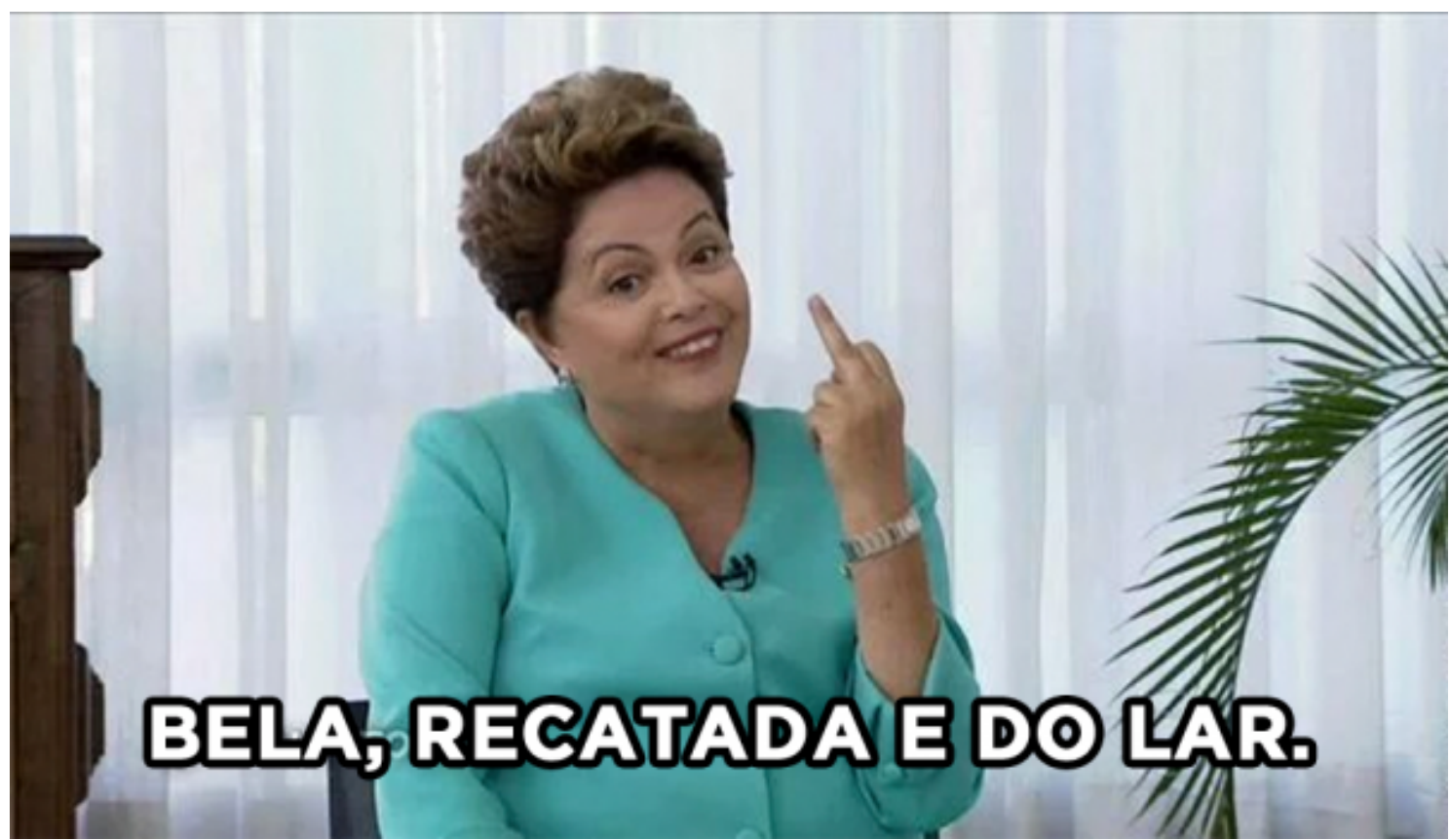

Fonte: http://www.museudememes.com.br/sermons/bela-recatada-e-do-lar/. Acesso em 03 de março de 2020 .

Numa foto montagem, a presidente Dilma, ator do enunciado memético, aparece apontando o dedo, gesto indelicado que normalmente não caberia a um chefe de estado pelos ritos do seu cargo, reprimindo o que seriam os valores patriarcais a serem aderidos (e da própria instituição governamental com o impeachment à espreita), de acordo com o que o enunciador-veja ofertou aos seus enunciatários-leitores.

As imagens das mulheres revelando seus corpos nos exemplos dos memes ressaltam o valor euforizado da liberdade, mas o tom de deboche só é atingindo quando temos a junção da imagem com o segmento visual. O sincretismo textual verbovisual deve ser visto no seu todo e não apenas nas unidades, ou perderia o efeito cômico pretendido pelo seu enunciador. Conteúdo e expressão e as relações semissimbólicas que 
possuem nos guiam para a leitura do texto, fazendo-nos compreender o seu sentido. O plano de expressão apenas reforça certos sentidos que já são dados pelo plano de conteúdo. A respeito do sincretismo textual, Discini elucida que

[...] o plano de conteúdo dos textos sincréticos confirma o posicionamento da enunciação na interpretação feita das coisas do mundo. Dessa interpretação decorre a substância conceitual, que é única, não apesar do sincretismo verbo-visual, mas justamente por conta dele (2018b, p. 123).

O verbal e o visual se complementam para a compreensão da enunciação do mundo tal como concebido pelo seu humor e, sobretudo, pelo seu enunciador. Beyoncé (Figura 21) revela seu derrière como uma resposta irônica ao texto da reportagem da Veja. Como diria Bergson (2018, p. 86) "Rimos sempre que a nossa atenção é virada para o aspecto físico de uma personagem quando é o aspecto moral que está em questão". O ator do enunciado figurativizado pela cantora Beyoncé, como todos os demais atores que vimos nos memes, possui o simulacro de uma mulher bela, livre e empoderada sem ser tolhida por vontades masculinas.

A reiteração do termo "bela, recatada e do lar" nos enunciados sincréticos dos memes também corrobora para a minimização (ZILBERBERG, 2011) do fato humorizado, ou seja, dos valores machistas ainda em voga, da quantidade de mulheres mortas por ano no Brasil e do abuso sexual que sofrem regularmente, quase que fazendo deles "pouco caso". A déraison, ou a "desrazão", a causadora do riso cômico da qual fala Baudelaire (2007), é na verdade o sensível para a teoria tensiva da semiótica. A finalidade dos memes é alongar, pela extensividade, o eixo da razão, o acontecimento intenso do mundo noticioso para poder criticá-lo satiricamente.

No texto-base temos Marcela Temer ocupando o papel temático da "bela, recatada e do lar", aquela que possui aparência de ter bons costumes, é discreta, boa mulher, boa mãe, obediente e submissa. Nas recriações meméticas, os papéis se invertem. As mulheres, atores dos enunciados, reclamam esse papel, mas o subvertem, constituindo a ironia. Elas disforizam o valor de opressão e euforizam a liberdade, transformando os memes em peças de paródia. Em reportagem do espanhol El País, o movimento foi chamado de "A fúria cômica das redes"43.

\footnotetext{
${ }^{43}$ MORAES, Camila. A fúria cômica das redes contra o "bela, recatada e dor lar". El País Brasil. 22 de abril de 2020.2 Disponível em: https://brasil.elpais.com/brasil/2016/04/20/politica/1461175399_885009.html. Acesso em 05 de março de 2020.
} 
Quanto ao enunciador memético, ele é semanticamente constituído como o ator da enunciação pela sua totalidade discursiva (GREIMAS; COURTÉS, p. 44-45), está, no entanto, presente em toda a sequência memética como uma voz e um estilo. Nos enunciados meméticos, mais precisamente na sua sintaxe discursiva, há o apagamento autoral do "eu" ou, pelo menos, ele não é explicitado. $\mathrm{O}$ ator da enunciação possui um éthos que se mostra contrário e crítico ao texto-base do qual o meme deriva.

Entretanto, o ator da enunciação não pode ser visto apenas como uma instância de um "eu" instalado no discurso, mas como "uma imagem concreta a que se destina o discurso" (FIORIN, 2004, p. 71), também como já afirmamos previamente. Fiorin, a respeito da instância da pessoa instaurada no discurso, diz que "mesmo que não haja um $e u$ explicitamente instalado por uma debreagem actancial enunciativa, há uma instância do enunciado que é responsável pelo conjunto de avaliações e, assim, um “eu” (FIORIN, 2016a p. 57, grifo do autor). Há, portanto, a figura de um observador, delegada pelo enunciador, que, adjuvante do narrador, é responsável pela avaliação do julgamento do ator do enunciado que condena a submissão feminina pela figura masculina.

A hashtag \#belarecatadaedolar ingressou nos trending topics do Twitter, que são os assuntos mais comentados da rede social por determinado período de tempo, em concomitância com a publicação da edição da revista Veja sobre Marcela Temer percebida como uma mulher voltada aos afazeres domésticos. O enunciador memético, através das diversas criações de memes que fazem parte do mesmo tópico discursivo (FECHINE, 2018), manipulou o enunciatário-usuário do meme a criticar os valores da matéria a qual mostrava a figura feminina em conjunção com a integração, no texto-base, e a aderir aos valores de liberdade dos textos meméticos. Contudo, isso é feito através da ironia e do humor, que fazem descer a curva do acontecimento intenso, veiculado pela revista Veja ao pregar valores do patriarcado em suas páginas, para a sensibilidade do riso e a inteligibilidade da crítica.

\subsection{Identidade $x$ Alteridade}

\subsubsection{Temer e os memes}

Durante a corrida eleitoral de 2018, Michel Temer já havia assumido a presidência, sucedendo Dilma Rousseff, que fora deposta em 2016. Temer amargurava 
$73 \%{ }^{44}$ de rejeição até perto do final de seu mandato. Escândalos envolvendo corrupção, e a greve de caminhoneiros, em junho de 2018, que paralisou o país por alguns dias, fizeram de Temer o presidente mais impopular do Brasil desde o fim da ditadura.

Desde o fim do governo Dilma, Michel Temer foi alvo de diversas piadas e memes nas redes que pediam pela sua saída. A frase \#foratemer virou bordão entre aqueles que consideraram a saída da presidente um golpe de Estado.

Figura 27 - Movimento "Fora Temer" na Avenida Paulista

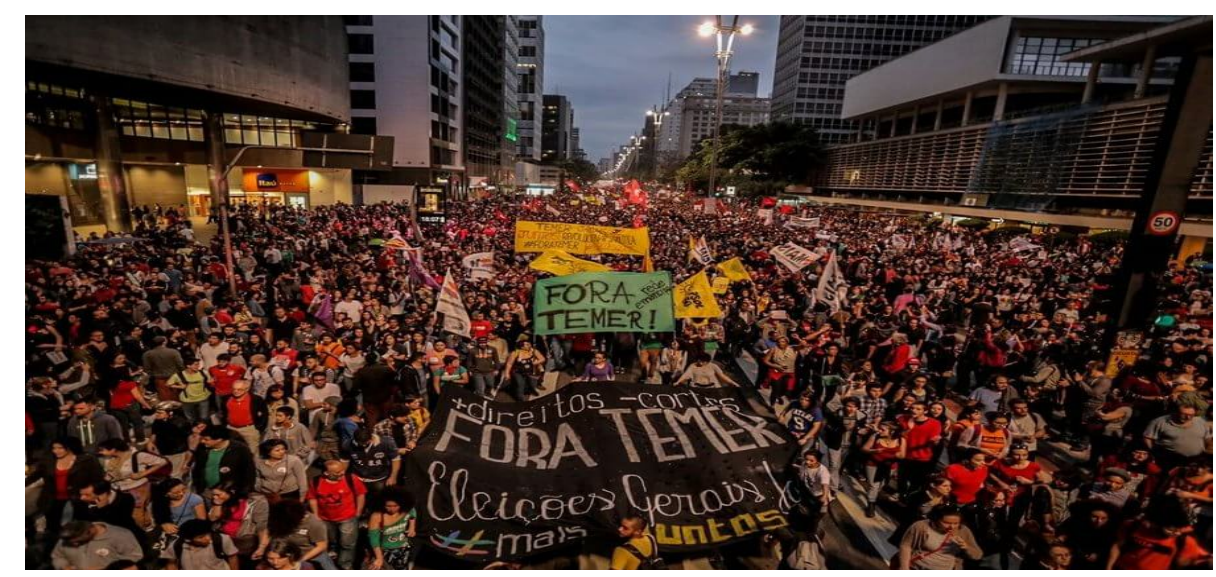

Fonte: https://cdn.brasildefato.com.br/media/81c40946ee29a379340265e4560451eb.jpg. Acesso em 16 de março de 2020.

${ }^{44}$ Após reprovação recorde, Temer encerra governo com rejeição em queda, mostra Datafolha . Folha de S. Paulo. 27 de dezembro de 2018. Disponível em: https://www1.folha.uol.com.br/poder/2018/12/aposreprovacao-recorde-temer-encerra-governo-com-rejeicao-em-queda.shtml. Acesso em 05 de março de 2020. 


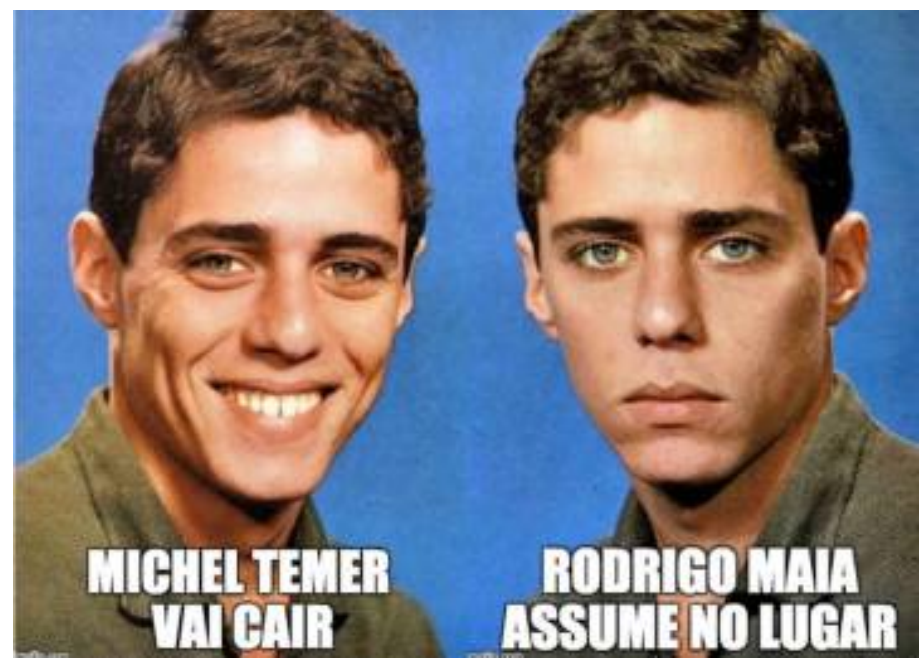

Fonte: https://images.app.goo.gl/x15zbXsP26w5b18b7. Acesso em 18 de março de 2020.

Em um dos memes que vieram à luz durante o movimento \#foratemer (Figura 28), não há um anafórico textual imediato ao grito das ruas "Fora Temer", mas se faz uma referência clara a ele.

Na sintaxe discursiva, a instância do "eu" do enunciador não está presente no enunciado, mas há um enunciador implícito e um narrador cuja voz é delegada ao ator do enunciado, figurativizado pelo cantor Chico Buarque, que afirma que "Michel Temer vai cair".

$\mathrm{O}$ ator do enunciado da esquerda, sujeito actancial no nível narrativo, está conjunto com o impeachment. Ele é modalizado pela paixão de desejo, de querer-fazer que o presidente caia.

Entretanto, com a saída de Temer, o próximo na linha sucessória é Rodrigo Maia, presidente da Câmara. Na possibilidade de que essa sucessão aconteça, o sujeito actancial apresenta uma paixão de medo e aversão, de não-querer-fazer. Essa quebra na expectativa do sujeito e a inversão dos valores iniciais causam o efeito cômico do enunciado memético.

Além do mais, Temer havia travado uma guerra contra os memistas para frear a reprodução de suas imagens se não dessem o devido crédito às fontes. Segundo reportagem ${ }^{45}$ divulgada pelo jornal online G1 no dia 24 de julho de 2017, a Presidência da República entrou em contato com algumas páginas da web criadoras de memes para

\footnotetext{
${ }^{45}$ Presidência da República faz alerta a sites que criam memes com fotos de Temer. G1. Tecnologia. 24 de maio de 2017. Disponível em: https://g1.globo.com/tecnologia/noticia/presidencia-da-republica-faz-alertaa-sites-que-criam-memes-com-fotos-de-temer.ghtml. Acesso em 24 de julho de 2019.
} 
alertar seus responsáveis que a partir daquela data as imagens do então presidente em exercício deveriam ter seu uso previamente autorizado caso o propósito não fosse jornalístico ou não servisse de material de propaganda política em favor do Governo Federal. Segundo a publicação, a nota dizia

Todas as fotografias estão liberadas para uso jornalístico e divulgação das ações governamentais. Para outras finalidades, é necessária autorização prévia da Secretaria de Imprensa da Presidência da República. (ibid.)

O objetivo da mensagem endereçada aos sites que produziam memes era, afinal, "realizar melhorias na produção e divulgação das fotografias oficiais do Exmo. Sr. Presidente Michel Temer". A reportagem dava a entender que o motivo da censura aos memistas (produtores de meme) era em respeito à bem-humorada crítica, contudo pouco lisonjeira, subjacente a esse gênero textual sincrético que é o meme.

O jornalista e filósofo Hélio Schwartsman, em sua coluna ${ }^{46}$ de opinião na Folha de S. Paulo do dia 28 de abril de 2018, intitulada “Guerra contra o humor", reportava uma notícia originalmente publicada pela revista britânica The Economist sobre a interdição imposta pelo governo chinês aos usuários da empresa Bytedance que tinham, através dela, acesso a notícias, vídeos engraçados e memes pela rede mundial de computares. Para Schwartsman "[...] o governo [...] parece estar caminhando para um endurecimento, preferiu não arriscar. A combinação de política com humor é potencialmente explosiva". O filósofo continua

Só que o humor pode também ser profundamente subversivo. As piadas que se contavam sobre as agruras do socialismo no Leste Europeu foram decisivas para a derrocada dos regimes comunistas, pois permitiram que as pessoas revelassem umas às outras suas desconfianças em relação ao sistema sem se expor em demasia. O riso coletivo, ao catalisar e sincronizar as desconfianças que indivíduos temem confessar até para si próprios, é uma das mais eficientes armas contra a tirania. O governo chinês tem razão em temê-lo. (ibid.)

Apesar da proibição, isso não impediu que memes fossem abundantemente produzidos pelos usuários. A própria interdição acabou virando um meme (Figura 29).

${ }^{46}$ SCHWARTSMAN, Hélio. Guerra contra o humor. Folha de S. Paulo. Opinião. 28 de abril de 2018. Disponível em: https://www1.folha.uol.com.br/colunas/helioschwartsman/2018/04/guerra-contra-ohumor.shtml. Acesso em 25 de julho de 2019. 
Figura 29 - Meme "Gates e Temer"

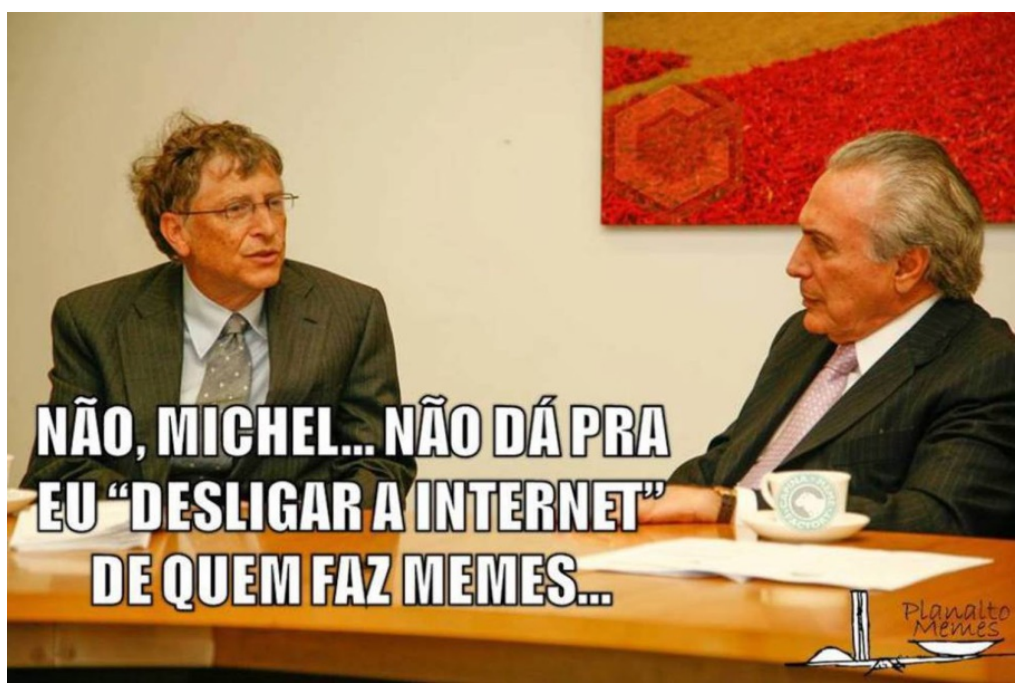

Fonte: https://imagens.brasil.elpais.com/resizer/N6-SH3hm7uJcrq0EuIGz1IJ03VU=/1500x0/arcuanglerfish-eu-central-1-prod-

prisa.s3.amazonaws.com/public/PCHTSQRYWI237REZ43TCFUXDJA.jpg. Acesso em 18 de março de 2020.

No meme "Gates e Temer" (Figura 29) o sujeito enunciador, por meio do narrador implícito, delega a voz ao ator do enunciado, o qual traz consigo um preenchimento semântico que se efetua no papel de dono de grande conhecimento em informática, figurativizado pelo ator Bill Gates. $\mathrm{O}$ enunciador do meme manifesta ser contra a proibição da confecção de memes de internet por parte do Planalto.

\subsubsection{A ascensão do Bolsonarismo}

Em 7 de outubro de 2018, o candidato Jair Bolsonaro saiu vitorioso do primeiro turno do escrutínio presidencial. Com mais de $40 \%{ }^{47}$ dos votos apurados nas urnas, ele disputaria o segundo, em 28 de outubro, com o candidato do PT, Fernando Haddad. Depois do resultado exitoso do então candidato do PSL à presidência nas eleições e uma demonstração eleitoral do PT muito aquém da que havia consagrado Dilma e Lula, veículos de imprensa davam como certa a vitória do capitão reformado do exército no pleito final.

Jair Messias Bolsonaro (sem partido) nasceu em 21 de março de 1955 na cidade de Campinas, São Paulo. De formação militar, iniciou-se na carreira política como

\footnotetext{
${ }^{47}$ BOLSONARO comemora resultado do primeiro turno e diz que unirá o país se for eleito. G1. 07 de outubro de 2018. 
vereador em 1988 na Câmara Municipal do Rio de Janeiro. Eleito deputado federal pela primeira vez em 1992 com inexpressiva votação de 17.674 votos, foi reeleito em 1994 com mais de 135 mil votos. Na sua promessa da campanha presidencial de 2018, ele advogou pela melhoria salarial da classe militar, pelo fim da estabilidade dos servidores públicos, o controle de natalidade da população brasileira e a remarcação da área dos índios ianomâmis ${ }^{48}$.

O discurso exacerbado do deputado virou uma tática política para angariar votos que tem se mostrado eficiente. $\mathrm{O}$ então deputado coleciona exemplos de falas oficiais, ou seja, pronunciadas no exercício de sua posição parlamentar, que inflamam os ânimos do público enunciatário do seu discurso.

Se a emoção vem antes da razão em matéria de voto, tudo é válido na eleiçãoespetáculo que se tornou a política brasileira na última década. Também são alguns exemplos de frases polêmicas do antigo deputado o que disse em certos momentos, como no da Hebraica da cidade de São Paulo, em 2017, que se fosse eleito presidente do Brasil em 2018 demarcaria as terras indígenas, pois onde tem terra indígena tem riqueza por debaixo. "Tem que ver isso daí”. Reforçando a justificativa de desapropriação dos índios, Bolsonaro continuou, em tom de crítica aos quilombolas: "Eu fui num quilombo. O afrodescendente mais leve lá pesava sete arrobas. Não fazem nada. Eu acho que nem para procriador ele serve mais. Mais de R \$1 bilhão por ano é gasto com eles" ${ }^{49}$. Arroba é uma medida usada para peso de animais como bois e vacas e equivale a $15 \mathrm{~kg}$.

Numa entrevista ao programa de televisão do apresentador Jô Soares, ele admitiu ter pedido o fuzilamento de Fernando Henrique Cardoso pois foi um crime cometido pelo ex-presidente a venda da Vale do Rio Doce, empresa mineradora, para capital estrangeiro. Atônito, o apresentador e comediante, em tom de deboche, disse que só fuzilando o expresidente para ele aprender o que não fazer. Bolsonaro então respondeu "Se eu não peço o fuzilamento de Fernando Henrique Cardoso, jamais você estaria me entrevistando aqui agora" ${ }^{50}$. A tática de "chocar" para se fazer aparecer deu certo. O presidente da república

\footnotetext{
48 VEJA a biografia de Jair Bolsonaro, presidente eleito do Brasil. Folha de S. Paulo. 28 de outubro de 2018. Disponível em: https://www1.folha.uol.com.br/poder/2018/10/veja-a-biografia-de-jair-bolsonaropresidente-eleito-do-brasil.shtml. Acesso em 15 de março de 2020.

${ }^{49}$ Bolsonaro é acusado de racismo por frase em palestra na Hebraica. Veja. 06 de abril de 2017. Política. Disponível em: https://veja.abril.com.br/brasil/bolsonaro-e-acusado-de-racismo-por-frase-em-palestra-nahebraica/. Acesso em 15 de março de 2020.

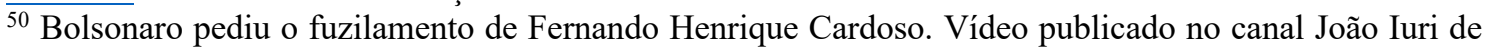
Oliveira no YouTube. 06 de maio de 2013. Disponível em: https://www.youtube.com/watch?v=tOCuftuLhUc. Acesso em 15 de março de 2020.
} 
normaliza em seus discursos a pena de morte, o racismo, o machismo, utilizando em seu vocabulário palavrões e xingamentos em relação a esse "outro" de seu desafeto.

\subsubsection{Memes e a crise de confiança}

No dia 07 de outubro de 2018, porém, podemos dizer que a internet acabou "fazendo as pazes" com o ex-vice. Com a ameaça de uma disputa acirrada no segundo turno e com a alavancada de uma direita totalitarista, os usuários pediam, sob forma de memes, a permanência de Michel Temer.

A hashtag \#ficatemer marca o forte tom debochado que está contido nos enunciados. O humor e o riso, parafraseando o filósofo Hélio Schwartsman, catalisam a vontade de um coletivo que expressa sua opinião e faz uso deles como uma arma contra uma provável repressão.

Através dos memes que analisaremos a seguir, o ator da enunciação "[...] se apresentará como pessoa discursiva inclinada a dever convencer o leitor para algum fim preciso e utilitário definido" (DISCINI, 2018a, p. 318).

No que diz respeito às qualidades plásticas do meme, o sensível do texto, é necessário que o destinatário seja modalizado por uma competência estésica (LANDOWSKI, 2014b, p. 13). Desse modo, Landowski diz ser importante distinguir a leitura, que é a "decifração das 'significações"” ocorrida quando se reconhece as formas figurativas do texto e a captura, que é a "apreensão do "sentido"” imanente aos objetos (idem, ibidem).

O autor define competência estésica como um exercício que supõe, da parte do sujeito, como

[...] a superação do modo de leitura do mundo definido pelo reconhecimento de unidades figurativas pontuais, e uma disposição para capturar efeitos de sentido oriundos das qualidades plásticas próprias aos objetos apreendidos em sua presença imediata, qualquer que seja seu estatuto actorial (parceiros humanos, obras ou objetos do mundo natural). Obedecendo ao princípio de sensibilidade (e, portanto, independentemente de qualquer intencionalidade orientada por objetivos do tipo "liquidação da falta"), essa competência permite o desenvolvimento do processo de ajustamento recíproco, até o "accomplissement" (desabrochamento) mútuo dos participantes. Expandindo-se à maneira de uma finalidade sem fim - sem alvo preestabelecido -, a competência estésica se constitui na medida mesma em que ela se exerce (LANDOWSKI, 2014b, p.17). 
Para Zilberberg (1992), a fala do devir do sujeito, do francês devenir, é que é um "vir-a-ser", a "transformalidade", como nos explica Discini (2018a, p. 327). Segundo o dicionário Le Micro Robert (2008), no verbete devenir, o termo significa passar de um estado a outro, começar a ser aquilo que não era ainda. É a partir desse momento, no encontro do sujeito com o objeto estético, no caso, os memes, que os valores são despertados e o sujeito passa de virtualizado para atualizado ainda nas estruturas semionarrativas.

No patamar discursivo, esse enunciatário se afirma no modo que ele "se vê" representado pelos enunciados dos memes, pelos estilos de vida, como alguém que é contrário aos ideais totalitários que se anunciam com a eleição de Jair Bolsonaro, isto é, um sujeito contra a tortura, contra a militarização, o uso de armas, o estupro, alguém de "gauche", para usar o exemplo do poeta Drummond, por assim dizer. O destinadormanipulador, também enunciador do meme, modaliza o sujeito a ir ao encontro do que fora estabelecido inicialmente pelo contrato inicial. O sujeito é disjunto dos valores totalitários, modalizado por uma paixão de querer-não-ser. O ser "gauche", e o estilo de vida que termo abarca, seria o devir do sujeito.

Num mundo polarizado e com lados bem demarcados, há a importância social de querer fazer demonstrar inclinação ideológica. Para isso, nos memes, rejeita-se o simulacro de um sujeito que disforize, por exemplo, a frase "prefiro um filho morto a homossexual" e euforize a aceitação do bem-estar de todos sem restrição de cor, gosto, credo ou preferência sexual; um bem-estar social. A sua identidade é na verdade um ser que procura em exemplos coletivos "[...] pela busca de um estilo autenticamente pessoal" (LANDOWSKI, 2012, p. 42). Levando-se em consideração a troca dos espaços virtuais por onde os memes circulam, os "projetos de vida" de bem-estar são negociados e atualizados e é também através desses projetos que os sujeitos se exprimem "mediante ao seu fazer o seu devir" (ibid.).

O "ser", para ser percebido na sua individualidade, é primeiramente um "ser" para esse "outro", a fim de ser definido como um "ser" de fato. Segundo Eric Landowski

[...] pois "ser" é também, necessariamente, ser "para o outro", é ser visto, avaliado, sondado e, finalmente, classificado em algum lugar, em função de coordenadas definidas pelo grupo de referência [...] nenhum indivíduo poderia se reconhecer e se realizar como tal a não ser procurando primeiramente se conhecer e se assumir enquanto membro de uma coletividade primeira que o englobe e que o defina (LANDOWSKI, 2012, p. 42). 
O "outro" aqui perde sua característica de diferente como encontramos nos discursos intolerantes. Na acepção de Landowski, o "outro" seria um parâmetro comparativo com quem o sujeito "ser" primeiro se identifica e reconhece para depois proclamar sua própria identidade.

O reconhecimento é, segundo Barros (2002, p. 112), a comparação interpretativa daquilo que não se sabe ainda, do desconhecido, ao que já é conhecido pelo mundo. A autora aponta que numa argumentação, diferentemente de uma simples adequação à realidade referencial, “[...] cotejam-se os valores e os procedimentos sintáticos utilizados pelo enunciatário, determinados por sua inserção na sociedade e na história” (ibid.).

Nos discursos intolerantes, na manipulação narrativa do destinador, o "outro", reiterando Diana Barros (2016), é axiologicamente disforizado na gramática fundamental. Já no patamar narrativo do percurso, ele é o mau cumpridor do contrato, aquele sobre quem recai a sanção negativa, enquanto o sujeito do "ser" se vê representado nos memes pelo efeito de identidade que se cria. Há um jogo de "parecer", um simulacro encontrado nos enunciados que remetem a essa constituição da realidade que se é criada no texto. Para Landowski (2012, p. 43), é a cena do "parecer", precedente ao "ser", que o constitui. Os papéis temáticos e figurativos conferem maior efeito de realidade do mundo enunciado e auxiliam na percepção desse sujeito.

Na sintaxe fundamental dos memes, estes pertencentes à mesma cadeia memética \#ficatemer, apesar de usar figuras diversas para lhes dar maior preenchimento semântico, a oposição semântica inicial, /identidade/ x /alteridade/, é subvertida na semântica axiológica. Os diferentes tornam-se "exaltados" na dêixis positiva, logo, euforizados. A identidade, em oposição, tal como promovida pelo discurso presidencial, é disforizada.

A oposição de base sobre a qual é produzido o sentido do texto fica mais bem explicada pelo quadrado abaixo: 


$$
\text { Identidade Alteridade }
$$

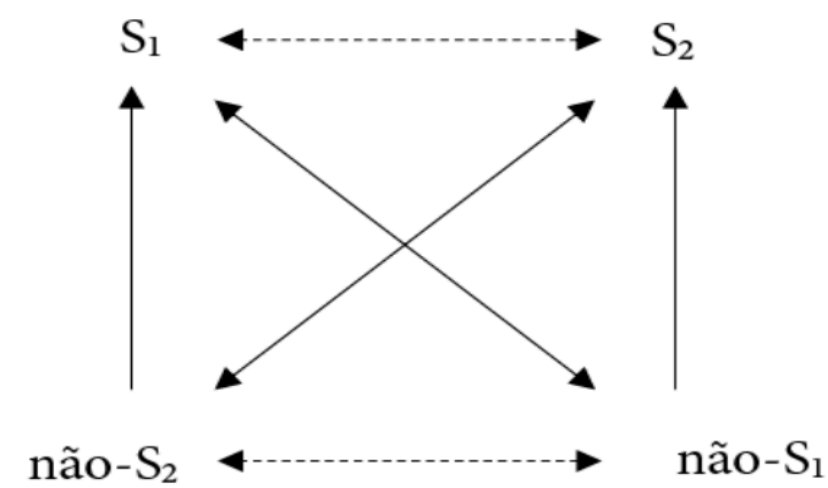

Não-alteridade

Não-identidade

Fonte: elaboração nossa

Nos exemplos dos memes se nega/identidade/, que é opressora, e se afirma /alteridade/, ou melhor, a identidade desse outro para quem não é dada a voz, mas apenas a sanção negativa, em um governo que se anuncia intolerante. Nos discursos de Bolsonaro esse outro é visto como um ele.

Os memes subvertem o valor axiológico do sujeito que é visto como diferente nos discursos de Bolsonaro. Nos memes das Figuras 31 (meme "todo mundo te ama"), 32 (meme "apagando os tweets") e 33 (meme "sem saber que estava na pior"), observamos nas figuras do nível discursivo negros e mulheres como atores do enunciado.

Figura 31 - Meme "Todo mundo te ama"

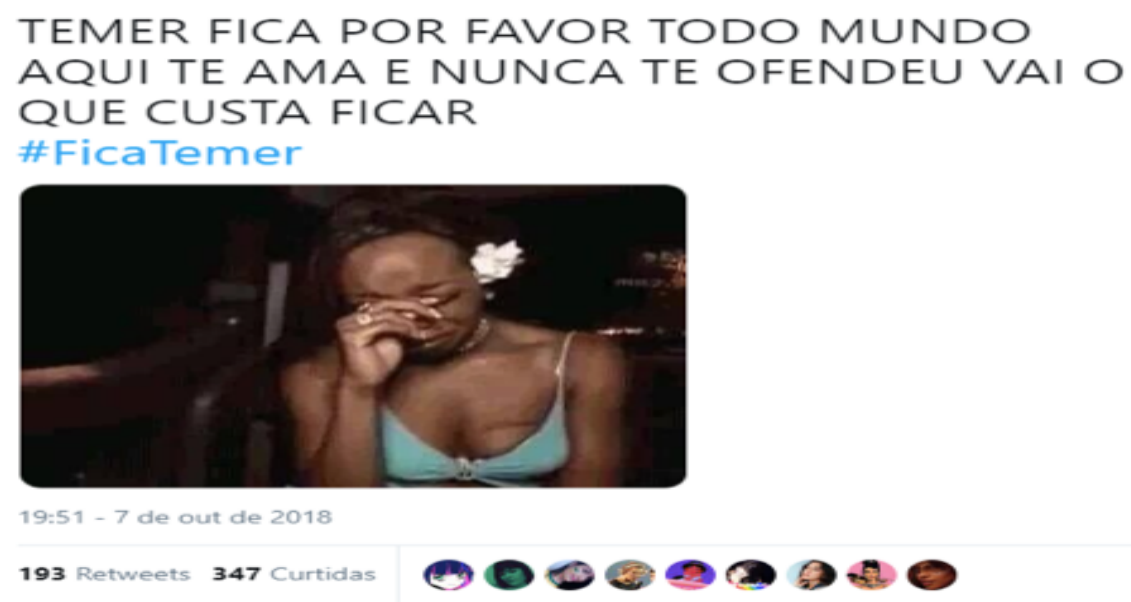

Fonte: http://www.museudememes.com.br/sermons/ficatemer/. Acesso em 27 de março. 
$\times \times$ Lucas

@Lucaschaoandre

\section{Apagando meus tweets falando mal do temer. Fica aí mesmo temer}

\section{\#FicaTemer}
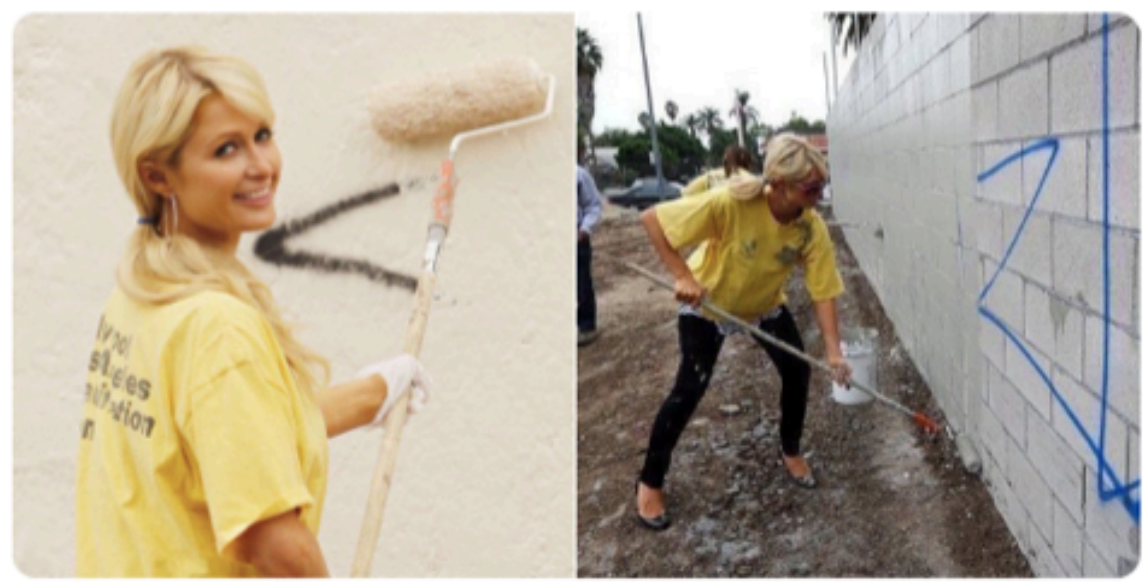

19:50 - 7 de out de 2018

Fonte: http://www.museudememes.com.br/sermons/ficatemer/. Acesso em 27 de março.

Figura 33 - Meme "Sem saber que estava na pior"
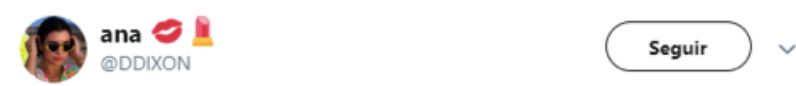

eu te julguei sem saber que algo pior estava por vir \#FicaTemer

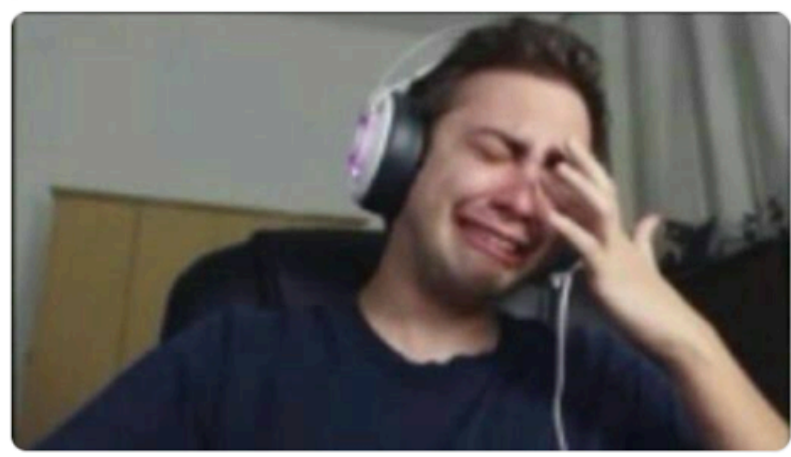

19:54 - 7 de out de 2018

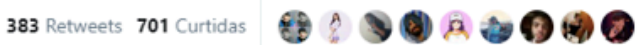

Fonte: http://www.museudememes.com.br/sermons/ficatemer/. Acesso em 27 de março. 
Nos memes supracitados, há uma inversão dos valores que encontramos nos discursos de Jair Bolsonaro. Enquanto para o (então) presidenciável, os ditos “diferentes" são aqueles cuja sanção é a máxima, na ordem do intenso, os memes fazem o contrário, aliviam e suavizam a crítica pelo bom humor. Como afirma Bergson (2018), paralelamente aos estudos discursivos, o riso reprime toda excentricidade.

Observa-se nesses memes (Figuras 31, 32 e 33) que no plano da expressão quase todos denotam, implicitamente, um efeito de sentido de insatisfação e decepção que os conecta figurativamente.

Para falarmos em percursos passionais, teremos obrigatoriamente que recorrer aos actantes e aos programas narrativos do percurso do sentido (BARROS, 2002, p. 62). Para a semioticista, a insatisfação e a decepção são, na perspectiva da intensidade e da foria,

[...] estados intensos e não-eufóricos de não-conjunção [sujeito e objeto]. [...] A insatisfação e a decepção podem ser determinadas aspectualmente pela duração e prolongar-se em novos efeitos passionais: a mágoa que perdura ou a resignação [...]. Outra possibilidade é a da insatisfação e da decepção conduzirem ao sentimento de falta, definido pelo /querer-ser/ em conflito com o/sabernão-ser/ e com o /crer-não-ser/ e característicos da crise de confiança (idem, p. 64-65).

Essa falta de confiança que nos indicou Barros (2002) acompanha uma paixão de malevolência que induz a um querer-fazer o mal a alguém. O querer-fazer que modaliza o sujeito dirige-se, na verdade, ao sujeito responsável pelo sentimento de falta e pela crise de confiança. Nesse caso, o então futuro presidente Jair Bolsonaro adquire esse papel actancial do sujeito de quem se quer, como sanção, impedir a chegada ao Planalto. Bolsonaro seria o antissujeito.

No meme da Figura 32 o sujeito apaga o muro com um rolo de tinta simbolizando as antigas mensagens de críticas que supostamente tinha feito ao presidente Temer na época do impeachment, o que ratifica a paixão de desprendimento ou arrependimento /não-querer-ser/ do sujeito com suas antigas afirmações contra o presidente Temer, atribuindo a este sujeito efeito de crise de confiança.

As disposições patêmicas, de acordo com o contrato de veridicção, estão na dêixis entre o ser e o não parecer, logo, um segredo. Se analisarmos apenas o segmento visual do meme, no que está na Figura 32, "apagando os tweets" não se revela de imediato qual a paixão que modaliza o sujeito. Seríamos levados a acreditar, primeiramente, que se trata de uma paixão de bem-querência ou de desejo, /querer-ser/, mas essa expectativa do leitor-enunciatário é quebrada quando se soma à imagem verbal: querer a volta de Temer 
representava frear a ascensão bolsonarista e também a consciência de que o que estava por vir era ainda pior.

Figura 34 - Meme "Iti Malia modezu"

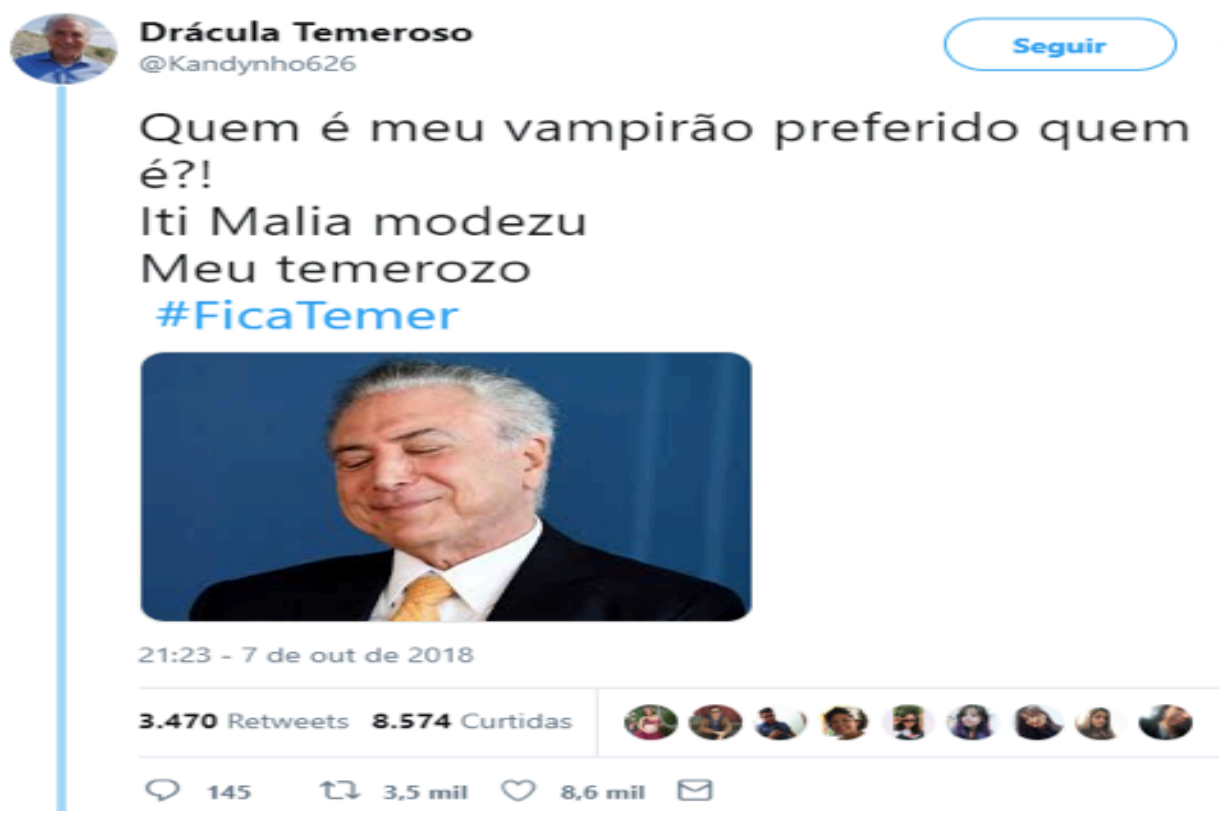

Fonte: http://www.museudememes.com.br/sermons/ficatemer/. Acesso em 27 de março de 2020.

Figura 35 - Meme "Dentro do meu coração"

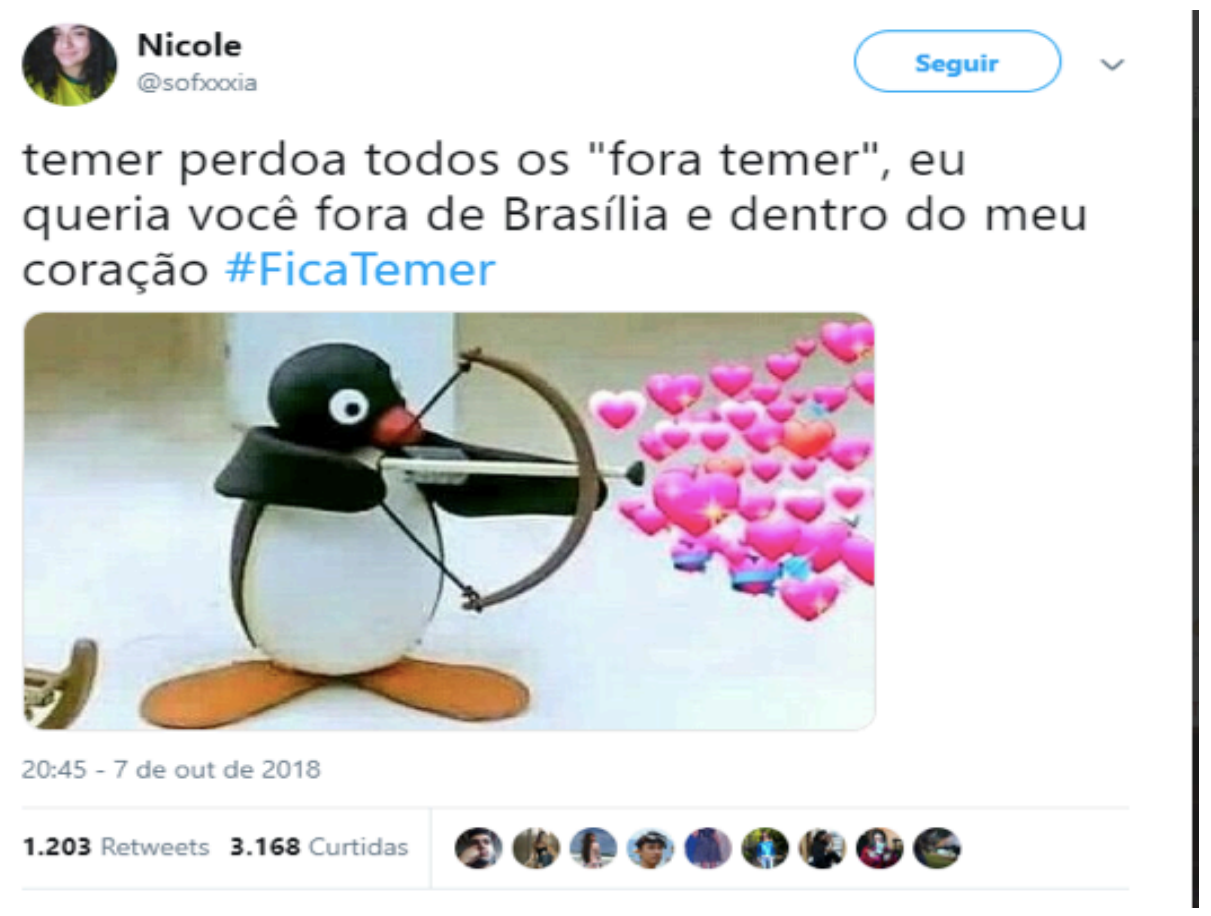

Fonte: http://www.museudememes.com.br/sermons/ficatemer/. Acesso em 27 de março de 2020. 
No meme "Iti malia modezu" (Figura 34), pela feição figurativizada do ator Temer aparentemente envaidecido, o sujeito actancial foi manipulado a entrar em conjunção com o amor de quem antes lhe considerava um antissujeito que havia infligido um golpe. No meme "Dentro do meu coração" (Figura 35), na manifestação da imagem verbal, a paixão de medo, /querer-não-ser/, pela troca presidencial, e de insatisfação e decepção pelo o que está por vir, /não-crer-não-ser/, pela disjunção com a inclinação totalitarista que Bolsonaro proclama em seus discursos, está claramente lexicalizada: “temer, perdoa todos os 'fora temer', queria você fora de Brasília e dentro do meu coração".

Para que o discurso de Bolsonaro, visto como um autor-destinador na sintaxe narrativa, fosse aceito pelo destinatário do meme da cadeia \#ficatemer, seria necessário que houvesse uma mudança de contrato, ou a manipulação não seria eficaz. Nas palavras de Barros (2002, p. 39), é preciso haver uma certa cumplicidade entre destinador e destinatário ou então o destinatário deve propor um novo sistema de valores, o que neste caso não acontece.

Os memes, ao recusar o resultado do primeiro turno das eleições presidenciais, propõem um novo valor para que justamente esse "outro", apartado nas declarações do presidenciável, se reconheça e participe do jogo de replicação, coprodução e compartilhamento dos memes. Só com a proposição de valores novos a persuasão surtirá efeito.

Os memes \#ficatemer fazem uma referência indireta às declarações de Jair Bolsonaro, mas o colocam em outro contexto, conferindo polêmica ao discurso. Nos memes em questão, enuncia-se indiretamente o discurso de Bolsonaro, mas ele é negado na enunciação, quando se pede que o antigo presidente Temer permaneça no cargo. A respeito da polêmica no discurso, de acordo com Discini (2004b, p. 60) "Falamos de uma polêmica que, ao construir um discurso polifônico por excelência, apresenta uma dupla leitura inscrita na situação de enunciação construída pelo texto". Na polêmica do meme, duas isotopias são produzidas: a de recusa do futuro governo, essa manifestada pela preferência ao anterior, e outra de protesto.

A função fática do discurso, o efeito de aproximação entre enunciador e enunciatário, revela-se na sua textualização: as imagens são sempre muito próximas, focadas no ator do enunciado, que expressam um efeito de sentido de paixão, de arrependimento e medo, dando a ideia de que se arrependem de ter pedido a saída de Temer, visto o discurso truculento do então futuro ocupante do cargo. 
A intertextualidade pode ser conferida logo no segmento verbal do texto, \#ficatemer, em contraposição com uma outra cadeia memética ocorrida em período anterior, \#foratemer, este considerado texto-base, configurando uma relação parodística e interdiscursiva.

Norma Discini (2004b) nos diz que a paródia se compõe por uma inversão. Segundo a autora

A paródia inverte, portanto, o texto-base, mas tem nele sua mira enunciativa, o que significa que se mantém apegada a ele. São os valores do texto-base que a orientam, por isso ela constrói seu discurso para contrariar tais valores (DISCINI, 2004b, p. 39).

O efeito cômico, ou o desvio que leva ao cômico, como diz Bergson (2018), estaria presente nesse descompasso entre o texto-base e a derivação memética, formando uma paródia, ao mesmo tempo que a polêmica marca o protesto e o perfil judicativo do seu enunciador. Segundo afirma Discini, "podemos deduzir que, quanto às marcas discursivas, o riso está para a paródia assim como o protesto está para a polêmica" (DISCINI, 2004b, p. 47).

Shifman (2019, p. 46) afirma que o sucesso de popularidade dos memes é dado pela "vocalização mundana de vários usuários". A autora complementou, a respeito dos textos meméticos utilizados em tempos de repressão, que eles auxiliavam no reconhecimento ideológico das pessoas que estão em oposição às ordens governamentais. Para a autora

Memes políticos podem ser analisados como ferramentas de expressão coletiva e discussão. Considerando que a criação de memes é um meio divertido e prazeroso de vociferar opiniões, eles têm sido usados para transmitir uma grande gama de sentimentos políticos [...]. Em regimes não democráticos, como a China, memes políticos podem carregar um significado especial de protesto contra o governo [...]. Expressões amplamente baseadas em memes de pontos de vista subversivos funcionam em ambientes rigidamente controlados como um sinal aos demais cidadãos que eles não estão sozinhos na oposição, possivelmente quebrando "espirais de silêncio" [...] ao expressar vozes supostamente minoritárias (idem, p. 48) ${ }^{51}$.

\footnotetext{
${ }^{51}$ Do original, "Political memes can also be analyzed as tools for collective expression and discussion. Since the creation of memes in an accessible and enjoyable route to voicing opinions, they have been used to convey a wide range of political sentiments [...]. In nondemocratic regimes, such as China, political memes may carry an additional important meaning of anti-government protest [...]. Extensive meme-based expressions of subversive standpoints in tightly controlled environments signal to fellow citizens that they are not alone in their opposition, possibly breaking 'spirals of silence' [...] by expressing allegedly minority voices". Tradução nossa.
} 
Memes são, então, de acordo com Limor Shifman (2019), a maneira divertida e fácil de se entrar num protesto contra uma determinada agenda política ou até contra o próprio governo. Entretanto, discordamos semioticamente dos atributos de coisa fácil e divertida simplesmente, relativos aos memes. Existe uma racionalidade refinada, uma complexidade inteligível de função relevante, a serem apreendidas e analisadas, o que justifica nossa dissertação.

Através da "sinalização" que adentra o campo perceptivo do sujeito, para utilizarmos os conceitos de Zilberberg (2011), ocorre o reconhecimento dos valores axiológicos investidos nos objetos de valor, que são esperados como futura conjunção em relação ao grupo de enunciatários ao qual o meme se endereça. O enunciador memético deixa traços que compõem um estilo de enunciar que é próprio a essa cadeia memética em particular.

Fiorin (2018, p. 51), sobre o estilo em Bakhtin, assinalou que

[...] estilo é o conjunto de traços fônicos, morfológicos, sintáticos, semânticos, lexicais, enunciativos, discursivos, etc..., que definem a especificidade de um enunciado e, por isso, criam um efeito de sentido de individualidade.

O modo de enunciar já delimita quem é o enunciatário. Pela escolha lexical, pela temática e pelas figuras selecionadas. Ao fazer uso de recursos lexicais como erros gramaticais, falta de pontuação, expressões que se adequam melhor ao seu público, como "iti malia ${ }^{52 " ~(F i g u r a ~ 34), ~ c r i a-s e ~ e f e i t o ~ d e ~ a p r o x i m a c ̧ a ̃ o ~ c o m ~ u m ~ e n u n c i a t a ́ r i o-l e i t o r ~}$ conectado que está de acordo com o valores ofertados pelo enunciador e contra as declarações do presidenciável Jair Bolsonaro.

O leitor, ao se deparar com um desses memes, poderia ter a ideia errônea, num primeiro olhar, de que o debate ficaria restrito ao fácil escapismo humorístico. Contudo, pela extensão e pela propagação dos memes, o discurso memético torna-se complexo pela atenuação do intenso dos discursos intolerantes, pela forma de construir a ironia encontrada pelo enunciador e de conseguir ganhar a adesão do enunciatário. Como diz Maingueneau (2013), todo enunciado trata de algo que é dito para alguém sob alguma intencionalidade. Neste caso, a intencionalidade do enunciador é fazer um protesto, ao mesmo tempo em que faz parecer que está querendo apenas arrancar gargalhadas do seu público-enunciatário.

52 “Iti Malia" é uma linguagem comumente usada na internet que corresponde à expressão "Vixe Maria" 
Mais do que fazer o enunciatário reconhecido rir de si mesmo pelo absurdo paradoxal de não mais querer a saída de Temer, mas que, além de ficar, ele também governe pelos próximos quatro anos de mandato, a intencionalidade do destinador é fazer o alerta, entre os enunciatários pressupostos do meme, de uma possível catástrofe com a chegada do então futuro governo. Entretanto, isso é feito de maneira irônica.

Para os estudos discursivos, a ironia é bivocal, ou seja, existem duas vozes: uma que diz o enunciado e outra que nega a enunciação. Os memes da cadeia \#ficatemer se mostram irônicos na medida que manifestam o desejo de permanência de Temer na presidência e recusam o discurso totalitarista do então futuro presidente.

A fim de compor a temática do texto memético, o enunciador utilizou de maneira reiterada personagens que não fazem parte do espectro político (Figuras 31, 32 e 33). As diferentes figuras de "outros", representando a vontade de um grupo coletivo de barrar a ascensão de um governo repressor, ratificam as diferentes vozes que estão implicadas na enunciação memética. Não é apenas a voz do enunciador que fica evidenciada, mas também a do grupo, de um actante coletivo.

$\mathrm{O}$ ator da enunciação dos memes da cadeia \#ficatemer se destina a provocar em seu público uma identificação do leitor-enunciatário com a cena enunciativa que invoca. Quando o ator se assume como um "eu", debreagem enunciativa, em todos os enunciados meméticos da cadeia em questão, este pode corresponder tanto ao indivíduo quanto a um conjunto, ator coletivo, que considera a ideia de Bolsonaro no mais alto cargo do país como algo que causa repúdio. No cotejo com Maingueneau (2013, p. 154, grifo do autor), quanto à sua discussão a respeito de um " "eu' de identificação", esse "eu” do enunciador (sintaticamente visto como um sujeito actancial), que se transforma no "eu" ator da enunciação ao assumir uma posição semântica, destina-se a servir de lugar de inscrição do enunciatário, sendo este último "convidado" a tomar o lugar do "eu" no enunciado (idem, ibidem).

O autor de "carne osso" do meme não existe senão por marcas da enunciação que nos remetem à sua imagem, logo, ao ator da enunciação. Mariana Barros (2019), diz que esse "apagamento" da pessoa do "eu" explícito "[...] enfraquece o vínculo enunciador e enunciado, e ainda entre enunciatário e enunciado" (BARROS, 2019, p. 509), porém fortalece os laços entre enunciador e enunciatário. No entanto, na figura do enunciador memético subjaz um éthos o qual é composto por um tom, um caráter e um corpo. Os modos de enunciar do meme apontam para esse éthos do enunciador, pela maneira como é percebido pelo enunciatário, que também remete à imagem do ator da enunciação. 
Portanto, será um éthos quando aquele que proclama "eu" na enunciação é também o "eu" da imagem que quer passar ao seu público (FIORIN, 2007). 


\section{CONSIDERAÇÕES FINAIS}

É a hora de juntar todas as pontas que deixamos abertas ao longo da dissertação e dar um nó bem rente nessa desafiante jornada que foi estudar os memes de internet. Primeiramente, a escassa produção acadêmica sobre o assunto, pelo menos até a época de desenvolvimento da pesquisa, apesar do uso intenso do gênero pelos internautas, ainda oferece uma barreira para se olhar para o nosso corpus como um discurso sobre o qual a ciência da linguagem deveria se debruçar. A combinação humor e internet não é levada tão a sério, apesar de tudo.

Nós objetivamos entrar nesse mundo ainda pouco explorado teoricamente da enunciação online através dos memes. Eles existem, disso sabemos. Apesar de não conhecer muito sobre o gênero meme antes de iniciarmos o nosso estudo, já nos chamava a atenção o vivo uso de memes durante as eleições e como eles circulavam com relativa facilidade no Facebook e em grupos do WhatsApp, por exemplo. Por carregarem uma certa dose de humor, os memes podem funcionar como certo alívio oferecido pelo mundo noticioso. Por terem um viés discursivo crítico, eles conseguem repassar sua mensagem para um grande número de pessoas, atingindo por final um grupo que comungue dos valores vinculados nesses enunciados sincréticos.

Se o cenário político não favorece o debate público, os memes oferecem essa plataforma de expressão anônima. O humor cumpre o papel de dar relativo alívio a qualquer mal social que se instale na vida em sociedade. Como disse Bergson (2018), o humor não é justo. Ele pode culpar inocentes e poupar culpados no seu julgamento moralizante. Disso, ninguém está livre. Porém, numa análise semiótica, interessa o efeito de sentido produzido no interior dos memes e a construção da sátira que "destrói" moralmente seu alvo.

No nosso trabalho, começamos abordando a origem do termo meme, advinda da teoria de Richard Dawkins (2007). Isso posto, começamos a traçar uma breve trajetória dos memes (entendidos como uma unidade cultural genética que se propaga pelo contágio). Se a ideia de Deus é um meme, para o autor, é porque o conceito de Ser Supremo presente em diversas religiões foi passado de pessoa em pessoa, com auxílio dos textos escritos, que fizeram perpetuar essa ideia por gerações.

Em seguida, observamos como esses genes culturais foram pouco a pouco se inserindo dentro da cultura digital. Marino (2018, p. 14-15) defende que primeiro foi 
atribuída a alcunha de proto-meme ou pré-meme às mensagens de corrente por e-mail, aos boatos, aos vírus de internet e aos conteúdos circulados dentro dos grupos de discussão. Mais tarde, vieram os sites como 4chan e Reddit, que produziram os primeiros textos meméticos, ainda que de maneira rudimentar. Por último, chegou o avanço tecnológico das redes sociais e das ferramentas de tratamento de imagem que permitiram a ampla disseminação desse gênero, transformando os memes em um gênero discursivo de uso frequente na web. Os memes eram então tratados como uma prática da subcultura online.

Shifman $(2014,2019)$ e Chagas $(2017,2018)$ possuem pesquisas sobre os impactos da memética na cultura contemporânea. Para isso eles dão um enfoque especial para a função do meme na realização da temática política, o que trouxe enorme contribuição para o nosso trabalho. Os autores abordam como aquelas figuras de aparente "desleixo" estético provaram sua eficiência em incitar a ação política por parte do cidadão comum conectado. Shifman (2014) afirmou que ao reproduzir, replicar e compartilhar um meme, o enunciador diz mais a respeito de si do que sobre o meme que compartilha. Essas primeiras literaturas foram essenciais para entendermos o nosso objeto não apenas como textos que circulam na internet, mas como uma nova prática que merecia um maior aporte acadêmico de nossa parte.

Fechine (2018) realiza o primeiro trabalho pela perspectiva da sociossemiótica de Eric Landowski (2014) a respeito dos memes. A autora, apoiada nos estudos de Marino (2018), concede-nos um importante instrumento de análise para agrupar os memes de internet pelas isotopias temático-figurativas que os compõem no nível discursivo. No entanto, por mais que seus estudos tenham sido de grande contribuição para nós, ainda nos restava elucidar metodologicamente como fazer a conversão da aparência para a imanência, isto é, do plano de expressão sincrética para o plano do conteúdo, no qual o ator da enunciação memética se firma como um éthos, com voz, tom de voz e caráter, ao satirizar o estado das coisas no âmbito da política.

Os estudos semióticos de Algirdas J. Greimas (1977, 1993, 2012, 2014), bem como os desdobramentos tensivos (ZILBERBERG, 2001, 2007, 2011), pela estrutura teórica que possuem, ajudaram-nos a desvendar alguns dos mistérios de como nasce o sentido a partir de duas linguagens de manifestação, um visual e outra verbal. A enunciação no texto meme tira proveito do sincretismo verbovisual para compor-se como ator da enunciação memética. Pela Semiótica Discursiva, no seu patamar mais abstrato, que é o nível fundamental, observamos os valores axiológicos sobre os quais os textos 
meméticos se apoiam. Já na conversão das categorias semio-narrativas, vimos como os memes funcionam na narratividade para se compor, no nível discursivo, como textos persuasivos. No nível discursivo de cada meme, e da totalidade deles, constatamos que o gênero incita o leitorado a aderir aos valores propostos pelo enunciador. O meme acaba por desempenhar uma função que se avizinha à de uma peça de propaganda política, o que afirmamos a partir dos estudos de Viktor Chagas (2017, 2018). Logo, os memes de temática política se firmaram como um gênero que pode e sabe estimular o engajamento do usuário online. Melhor falando, o gênero memético instiga o fazer-político do internauta. Comprovou-se que o enunciador do meme, pelo seu fazer-persuasivo, inflige um fazer-interpretativo no seu enunciatário, fazendo emergir percursos passionais, modalizando competências e paixões tanto simples quanto complexas.

O enunciador do gênero discursivo meme faz o seu julgamento através da figura de um narrador-observador que funciona como fiador do discurso. É ele que faz o enunciatário crer que o que é dito é verdade, ou seja, o que está exposto em cada meme tanto parece quanto é. Para isso, o narrador sempre implícito (FIORIN, 2016a) lança mão de estratégias. Assim se compõe o ator da enunciação dos memes: entre o efeito de humor, a sátira, a incorporação da temática política e assim por diante. O memista, visto como um caricaturista contemporâneo que deixa a sua obra "em aberto" para que outros possam dela participar, retrata aspectos físicos e morais do personagem político escarnecido somado ao ajustamento cômico, nas palavras de Bergson (2018), ou à sanção através do humor, para nós semioticistas.

No nível discursivo, a instalação do "eu" discursivo define quem é o enunciador do texto. Sentimos que rendeu bastante para o estudo dos memes partirmos do princípio de que o enunciador não é o autor real, mas apenas uma posição sintática instaurada na categoria de pessoa. Pudemos entender que num texto sincrético, como por exemplo um texto que, escrito em $3^{\mathrm{a}}$ pessoa, faz a afirmação de que a ex-presidente Dilma é responsável pelo crime de pedaladas fiscais que lhe custou a presidência, por mais que o dêitico em primeira pessoa não esteja presente no segmento verbal nem sugerido na imagem visual, há sempre subtendido um “eu acho", “eu penso", “eu afirmo” e, por conseguinte, "eu faço o meme sobre isso".

O enunciador do meme, o "eu” do discurso, constrói na presunção da presença do “outro", o leitor-enunciatário, este que, para usar o mesmo exemplo dado anteriormente, também crê na culpa da presidente e faz a crítica através do meme. Em termos semióticos, o crer mobiliza o ser e o fazer da enunciação dos memes. O discurso é desenhado para 
capturar o enunciatário para que este possa e saiba aderir aos valores ideológicos propostos na enunciação memética entre a crítica e o humor. Os temas e as figuras do nível discursivo, as imagens que constam a partir do segmento visual são de suma importância para que o enunciatário não só entenda, mas incorpore sensivelmente o sentido do texto. O enunciatário é preparado também para não buscar a referência do meme que está em processo de leitura na memória de outras leituras, pois o meme acentua sua concomitância com o fato que "acabou de acontecer" no mundo noticioso.

A imagem do enunciador memético, considerado o ator da enunciação, ou seja, o enunciador pressuposto à totalidade de memes aqui recortados, instaurado em cada um deles como um narrador, transforma-se num éthos. Trouxe rendimento a noção de éthos para entendermos o ator da enunciação dos memes. Pela observação do modo como o enunciador memético se enuncia, pelo posicionamento que toma a favor de $\mathrm{x}$, contra $\mathrm{y}$, e, na textualização, pela escolha lexical, deparamo-nos com o caráter e o corpo do mesmo enunciador, assim encarnado como ator da enunciação memética. Essa imagem não é explícita no enunciado. Ela transparece no modo de se enunciar. Essa imagem quem produz é o enunciatário, e por isso ele é tão produtor do sentido do texto meme quanto o enunciador. Sobre a imagem do enunciatário, Fiorin (2007) explica, segundo a concepção dos autores do Dicionário de Semiótica, que

[...] o enunciatário é tão produtor do discurso quanto o enunciador (GREIMAS; COURTÉS, 1979) porque este produz o texto para uma imagem de leitor, que determina as diferentes escolhas enunciativas, conscientes ou inconscientes, presentes no enunciado. Ao colocar o enunciatário como uma das instâncias do sujeito da enunciação, Greimas e Courtés querem ressaltar seu papel de co-enunciador. Com efeito, a imagem do enunciatário constitui uma das coerções discursivas que o enunciador obedece: não é a mesma coisa produzir um texto para um especialista numa dada disciplina ou para um leigo; para uma criança ou para um adulto (FIORIN, 2007, p.29).

Pensar semioticamente a função do enunciatário na construção do sentido muito nos ajudou a trazer o meme à luz da semiótica, ainda que buscássemos subsídios em teorias paralelas. Um meme, como afirma Shifman (2019), é um meio divertido e prazeroso de dar voz a usuários para que eles expressem seus sentimentos em relação à política. Semioticamente, podemos traduzir a afirmação da pesquisadora israelense por efeito de sentido de humor, por partilhamento de confiança entre enunciador e enunciatário, e, em termos de um sujeito encarnado semântica e sintaticamente no discurso, o ator da enunciação propriamente dito, que se alinha ao éthos. Esse éthos do 
sujeito da enunciação (enunciador) lúdico, que enxerga no jogo do meme uma maneira de vociferar sua opinião, constrói de modo próprio o conflito social. O enunciatário, coenunciador e coprodutor do enunciado, foi então levado em conta em nosso estudo dos memes. Quando esse co-enunciador memético acolhe o teor beligerante de determinada crítica exposta no meme, temos condições semióticas para identificar um alívio ou diminuição da intensidade do problema tematizado, daquilo que a crítica resolve através do riso.

O acontecimento e o seu correlato, o exercício, são propostas de Zilberberg (2001, 2007, 2011). O primeiro é a grandeza que entra dentro do campo de presença de maneira inesperada ou abrupta, logo, de natureza intensa. O exercício, por sua vez, é da ordem do esperado, a grandeza que chega ao sujeito de forma átona, sem impacto, pois a mesma já era prevista pelo sujeito (BARROS, 2019). Pela ordem do acontecimento e do exercício tornou-se possível observar como são dados essa atenuação do que é intenso no discurso político dos ocupantes do poder e o ritmo lento da leitura do meme, que aspectualizam o ator da enunciação. A aspectualização actorial, como nos diz Discini (2015, p. 201), faz com que vejamos o ator no processo de suas moralizações e de suas percepções que dizem respeito aos fenômenos do mundo. O meme transforma, assim, o acontecimento, de alta intensidade, em exercício, de força átona, que se estende pela extensidade de duração mais longa e de espaço mais difuso, o que possibilita que o sujeito insira seu julgamento crítico.

Os teóricos do humor Bergson (2018) e Baudelaire (2007), que foram nossos referenciais para esse tópico, dizem que o humor é de certa forma irracional. Baudelaire (2007) diz que o riso necessita de um olhar malicioso e uma superioridade do observador da cena cômica, como quem diz "eu no lugar dele nunca teria tido igual e infeliz destino". É do outro que se escarnece. O poeta francês fala do riso como uma déraison (HAUGEN, 1988), que, segundo o dicionário Le Micro Robert (2008), significa algo desprovido de razão tanto nas palavras quanto na conduta. A desrazão institui o sensível na semiótica tensiva. Portanto, após atingir uma área de alta sensibilidade, o leitor do meme é levado a descender, a descer em sentido contrário, para que possa estabelecer a crítica social, que é racional e sensível.

Confirmamos na parte da dissertação dedicada ao humor que os memes são satânicos, irônicos e até desproporcionais quanto à sua crítica. Contudo, não interessa semioticamente que o riso seja ou não justo conforme as teorias sobre o cômico e o riso de Bergson (2018) e Baudelaire (2007). Interessa o efeito de sátira e de crítica social que 
faz o leitor partilhar dos valores do enunciador. Para surtir o efeito do cômico, aquele que é retratado no enunciado sincrético como mira da sátira faz aparecer a inteligibilidade das coisas, o que confirma a descendência do meme da zona da intensidade para a zona da extensidade. Essa aparente "dessensibilização" se avizinha à noção de exercício de Zilberberg $(2007,2011)$. Procuramos provar em nossa dissertação que se suaviza tensivamente aquilo que nos causaria paixões de medo ou raiva e desviamos (um pouco) a atenção do que nos causa transtorno para o caráter cômico do "outro".

Reconhecemos que o ator da enunciação dos memes não possui corporalidade definida previamente ao discurso. O ator da enunciação memética possui um caráter e um tom de voz que juntos formam o éthos crítico e lúdico. No caso dos memes, na falta de uma assinatura autoral, as relações entre enunciador e enunciatário poderiam ser consideradas afrouxadas. Mas não é o que acontece. Semioticamente, não importa que qualquer sujeito de carne e osso possa fazer a declaração de autoria ou que todos possam dela se ausentar. Cria-se, assim, o efeito de um ator coletivo. O que vale mais no jogo da troca do meme são os laços tecidos entre enunciador e enunciatário internos ao texto, aquele concebido como fiador do discurso, que mostra para este um segredo confessado do que "pensa e afirma", que se revela em verdade.

Ao se dizer " $e u$ " automaticamente se constitui o " $t u$ ". No humor do meme, esse "eu" que deprecia moralmente o "outro" também sugere uma reflexão sobre o "nós", enunciador e enunciatário do discurso actorializados em um único ator da enunciação. Se o riso necessita de um eco, é para exorcizar nossos medos e angústias para alguém que partilhe dessas mesmas preocupações. Na famosa citação do comediante francês Pierre Desproges (1939-1988) “On peut rire de tout mais pas avec n'importe qui”. É possível rir de tudo, mas não com qualquer um, em nossa tradução livre. Essa é a face velada do humor. A mira enunciativa do meme é certeira e provoca uma reação coletiva, um perigoso vírus cultural, pelo modo de compartilhamento da informação (e da crítica veiculada, da imagem do enunciador confirmada, da escolha lexical recorrente, do éthos lúdico e beligerante) que faz ganhar adesão do público enunciatário.

Esse enunciador pressuposto, encarnado sintática e semanticamente como o ator da enunciação pelo conjunto da sua obra, mordaz, e de refinada reflexão, ao conseguir transformar o absurdo implícito em humor, acaba por constituir um mecanismo em defesa da livre expressão. O riso e as lágrimas caminham de mãos dadas, pois, citando novamente Baudelaire (2007, p. 03), “[...] ambos [o riso e as lágrimas] são, do mesmo 
modo, filhos da aflição e surgiram porque o corpo do homem enfraquecido não tinha força para reprimi-los". 


\section{REFERÊNCIAS BIBLIOGRÁFICAS}

ARISTÓTELES. Arte retórica e arte poética. Rio de Janeiro: Editora Ediouro Tecnoprint, 1979.

BARROS, Diana Luz Pessoa. Teoria do discurso: fundamentos teóricos. $3^{\mathrm{a}}$ ed. São Paulo: Humanitas/FFLCH/USP, 2001.

BARROS, Diana Luz Pessoa. Estudos do discurso. In: FIORIN, J. L. (org.) Introdução à linguística II: princípios de análise. $3^{\mathrm{a}}$ ed. São Paulo: Contexto, 2004, p. 187-219.

BARROS, Diana Luz Pessoa. Teoria semiótica do texto. 4. ed. São Paulo: Ática, 2007

BARROS, Diana Luz Pessoa. A complexidade discursiva na internet. São Paulo: Cadernos de Semiótica Aplicada, v. 13, n. 2, p. 13-31. 2015.

BARROS, Diana Luz Pessoa . Estudos discursivos da intolerância: o ator da enunciação excessivo. Cadernos de estudos linguísticos, n. 58, v. 1, p. 7-24, jan/abril. 2016.

BARROS, Mariana Luz Pessoa. Os sentidos da tortura: uma análise semiótica das eleições de 2018. Discurso \& Sociedade, v. 13, p. 495-514. 2019

BAKHTIN, Mikhail. A Cultura Popular na Idade Média e no Renascimento: o contexto de François Rabelais/Mikhail Bakhtin. Traduzido por Yara Frateschi Vieira. São Paulo: Editora da Universidade de Brasília, 1987.

BAKHTIN, Mikhail. Estética da criação verbal. Prefácio à edição francesa de Tzvetan Todorov. Introdução e tradução do russo: Paulo Bezerra. $6^{\mathrm{a}}$ ed. São Paulo: WMF Martins Fontes, 2011.

BAUDELAIRE, Charles. Sobre a Essência do Riso. Revista UFG, v. 8, n. 2, p. 1- 10. 2017.

BARTHES, Roland. L'ancienne rhétorique. In: Communications, 16, p. 172-223. 1970. Recherches rhétoriques.

BENVENISTE, Émile. Problemas de linguística geral. São Paulo: Nacional/Edusp, 1976.

BERGSON, Henri. O riso - Ensaio sobre a significação do cômico; tradução e notas de Maria Adriana Camargo Cappello; introdução de Débora Cristina Morato Pinto. São Paulo: Edipro, 2018.

CALAME, Claude. O sujeito da enunciação: breve introdução. In: Cruzeiro Semiótico. Enunciação enunciada e semiótica discursiva I, n. 5, p. 9 -16. Associação Portuguesa de Semiótica, 1986.

CHAGAS, Viktor et al. A Política dos memes e os memes da política: proposta metodológica de análise de conteúdo de memes dos debates eleitorais de 2014. Revista 
Intexto, n. 38, jan/abr. 2017.

CHAGAS, Viktor. A Febre dos memes de política. Revista Famecos, v. 25, n. 1, jan/abr. 2018.

DAWKINS, Richard. O gene egoísta. São Paulo: Companhia das letras, 2007.

DISCINI, Norma. Estilo nos textos. $2^{a}$ ed. São Paulo: Contexto, 2004a.

DISCINI, Norma. Intertextualidade e conto maravilhoso. São Paulo: Humanitas, 2004b.

DISCINI, Norma. Para o estilo de um gênero. Bakhtiniana, v. 7, n. 2, p. 75-94. 2012.

DISCINI, Norma. Corpo e estilo. São Paulo: Contexto, 2015.

DISCINI, Norma. Gêneros discursivos em diálogo: a configuração do corpo autoral.

Revista Linguagem \& Ensino, v. 21, p. 305-358, 2018a. Disponível em:

https://periodicos.ufpel.edu.br/ojs2/index.php/rle/article/view/15197.Acesso em: 08 de janeiro de 2019

DISCINI, Norma. O estilo e o ator da enunciação: Greimas na contemporaneidade.

Estudos Semióticos, v. 14, n. 1 (edição especial), p. 117-132. 2018 b.

DISCINI, Norma. Claude Zilberberg: a semiótica estetizada. Estudos Semióticos, v. 15, p. 88-103, 11 abr. 2019.

FECHINE, Yvana. Pour une sémiotique de la propagation : invention et imitation sur les réseaux sociaux, Actes Sémiotiques, n. 121, p. 1-18, 2018.

FIORIN, José Luiz. A noção de texto em Semiótica. Organon, Porto Alegre, v. 9, n.23, p. 163-173, 1995.

FIORIN, José Luiz. O páthos do enunciatário. Revista de Lingüística Alfa, v. 48, n. 2, p. 69-78, 2004.

FIORIN, José Luiz. O sujeito na semiótica narrativa e discursiva. Todas as letras, v. 9, n. 1.2007.

FIORIN, José Luiz. As astúcias da enunciação. São Paulo: Ática, 2016a.

FIORIN, José Luiz. Elementos de análise do discurso. $15^{\mathrm{a}}$ ed. São Paulo: Contexto, 2016 b.

FIORIN, José Luiz. Introdução ao pensamento de Bakthin. $2^{\mathrm{a}}$ ed. São Paulo: Contexto, 2018.

FLOCH, Jean-Marie. Petites mythologies de l'oeil et de l'esprit : pour une sémiotique plastique. Paris/Amsterdam: Hadès/Benjamins, 1985. 
FLOCH, Jean-Marie. Syncrétiques (sémiotiques -) In : GREIMAS, Algirdas Julien ; COURTÉS, Joseph. Sémiotique: dictionnaire raisonné de la théorie du langage-II. Paris: Hachette, 1986. p. 217-219.

FLOCH, Jean-Marie. Alguns conceitos fundamentais em semiótica geral.

Documentos de estudo do centro de pesquisas sociossemióticas. São Paulo : CPS, 2001.

FONTANELLA, Fernando. O que vem de baixo nos atinge: intertextualidade reconhecimento e prazer na cultura do digital trash. Intercom - Sociedade Brasileira de Estudos Interdisciplinares da Comunicação. XXXII Congresso Brasileiro de Ciências da Comunicação. Curitiba, Paraná. 4 a 7 de setembro de 2009. Disponível em: http://www.intercom.org.br/premios/2009/Fontanella.pdf. Acesso em 19 de abril de 2019.

GREIMAS, Algirdas. Sémantique structurale : recherche de méthode. Paris: Larousse, 1966.

GREIMAS, Algirdas; COURTÉS, Joseph. Sémiotique: dictionnaire raisonné de la théorie du langage-II. Paris: Hachette, 1986.

GREIMAS, Algirdas; FONTANILLE, Jacques. Semiótica das paixões: dos estados de coisas aos estados da alma. Traduzido por Maria José Rodrigues Coracini São Paulo: Ática, 1993.

GREIMAS, Algirdas. Da imperfeição. Trad. Ana Claudia de Oliveira. São Paulo: Hacker, 2002.

GREIMAS, Algirdas. Acerca do jogo. Significação: Revista de Cultura Audiovisual, v. 34, n. 27, p. 11-22, 23 jun. 2007.

GREIMAS, Algirdas; COURTÉS, Joseph. Dicionário de semiótica. São Paulo: Contexto, 2008.

GREIMAS, Algirdas. Sobre o sentido II : ensaios semióticos. Tradução Dilson Ferreira da Cruz. São Paulo: Nankin, Edusp, 2014.

HAUGEN, Arne Kjell. Baudelaire: le rire et le grotesque. In: Littérature, no 72 , p. 12 29. 1988.

HERNANDES, Nilton. A trilogia matrix: estratéfias da enunciação sincrética em textos cinematográficos. Cadernos de Semiótica Aplicada, v. 3, n. 1. 2015.

HJELMSLEV, Louis. Prolegômenos a uma teoria da linguagem. São Paulo: Perspectiva, 1975.

HOUAISS, Antonio; VILLAR, Mauro de Salles; MELLO, Francisco Manuel de. Pequeno dicionário Houaiss de língua portuguesa. São Paulo: Moderna, 2015.

KALIL FILHO, Marcos da Veiga. Fake news e democracia: contribuições da semiótica discursiva acerca da verdade e da informação na internet. Cad. Letras UFF, v. 30, n. 
59, p. 205-2019. $2^{\circ}$ número 2019.

KNOBEL, Michele. Memes and Affinity Spaces: Some Implications for Policy and Digital Divides in Education. E-Learning, Volume 3, Number 3, 2007. Disponível em: https://www.researchgate.net/publication/250151508_Memes_and_Affinity_Spaces_So me_Implications for_Policy and_Digital_Divides_in_Education. Acesso em: $05 \mathrm{de}$ janeiro de 2019.

LANDOWSKI, Eric. A presença do outro: ensaios de sociossemiótica; tradução Mary Amazonas Leite de Barros. São Paulo: Perspectiva, 2012.

LANDOWSKI, Eric. Interações arriscadas; tradução Luiza Helena O. da Silva. São Paulo: Estação das Letras e Cores: Centro de Pesquisas Sociossemióticas (CPS), 2014a.

LANDOWSKI, Eric. Sociossemiótica: uma teoria geral do sentido. Revista Galáxia, n. 27, p 10-20, jun. 2014b.

MAINGUENEAU, Dominique. Gênese dos discursos. São Paulo: Parábola Editorial, 2008a.

MAINGUENEAU, Dominique. A Propósito do éthos. In: MOTTA, Ana Raquel;

SALGADO, Luciana (orgs). Éthos discursivo. São Paulo: Contexto, 2008 b.

MAINGUENEAU, Dominique. Análise de textos de comunicação; tradução de Maria Cecília P. de Souza-e-Silva, Décio Rocha. 6ª ed. São Paulo: Cortez, 2013.

MANCINI, Renata. ALT, João. Quadrinhos: do papel à internet. In: TEIXEIRA, Lucia; CARMO Jr, Roberto José (orgs.). Linguagens na Cibercultura. São Paulo: Estação das letras e cores, 2013.

MARINO, Gabriele. Qual semiótica da propagabilidade: uma abordagem sistemática de memes e virais de Internet. Revista Ícone, v. 16, n. 1, p. 9-40, 2018.

MENDES, Conrado Moreira. Semiótica e mídia: uma abordagem tensiva do fait divers. Tese (Doutorado em Linguística Geral Semiótica). Universidade de São Paulo. São Paulo, 2013.

POSSENTI, Sírio. Os humores da língua. $1^{a}$ ed. Campinas: Mercado das letras, 1998.

POSSENTI, Sírio. Humor, língua e discurso. $1^{\text {a }}$ ed. São Paulo: Contexto, 2014.

REY, Alain et al. Le Robert micro. Paris: Poche, 2008.

SARAIVA, José Américo Bezerra; LEITE, Ricardo Lopes. Exercícios de semiótica discursiva. Fortaleza: Imprensa Universitária, 2017.

SAUSSURE, Ferdinand de. Curso de linguística geral. $28^{\circ}$ ed. São Paulo: Cultrix, 2012. 
SCHWARTZMANN, Matheus. A noção de texto e os níveis de pertinência da análise semiótica. Estudos Semióticos, v. 14, n. 1, p. 1-6, 2018.

SHIFMAN, Limor. Memes in a Digital Culture. Cambridge: MIT, 2014.

SHIFMAN, Limor. Internet memes and the twofold articulation values. In: GRAHAM, Mark; DUTTON, William H. Society and the internet: How networks of information and communication are changing lives. $2^{\mathrm{a}}$ ed. New York: Oxford University Press, 2019.

TATIT, Luiz. Semiótica à Luz de Guimarães Rosa. São Paulo: Ateliê Editorial, 2010.

TATIT, Luiz. A abordagem do texto. In: FIORIN, J. L. (org.) Introdução à linguística I: objetos teóricos. $6^{\text {a }}$ ed. São Paulo: Contexto, 2011. p. 187-209.

TATIT, Luiz. Passos da semiótica tensiva. $1^{\text {a }}$ ed. Cotia, SP: Ateliê Editorial, 2019.

TEIXEIRA, Lucia. Para uma metodologia de análise de textos verbovisuais. In:

Linguagens na comunicação: desenvolvimentos de semiótica sincrética. São Paulo:

Estação das letras e cores, 2009, p. 41-77.

ZILBERBERG, Claude. FONTANILLE, Jacques. Tensão e significação. Traduzido por Ivã Carlos Lopes, Luiz Tatit e Waldir Beividas. São Paulo: Discurso Editorial:

Humanitas/ FFLCH/USP, 2001.

ZILBERBERG, Claude. Louvando o acontecimento. Revista Galáxia, n. 13, p. 13-28, jun. 2007.

ZILBERBERG, Claude. Elementos da semiótica tensiva. São Paulo: Ateliê Editorial, 2011. 


\section{LISTA DE REFERÊNCIA DE SITES DE NOTÍCIAS E VÍDEOS}

AGÊNCIA O GLOBO. No Brasil 92\% dos lares têm celular mas apenas $66 \%$ tem esgoto tratado. Época negócios. Brasil. 24 de novembro de 2017. Disponível em: https://epocanegocios.globo.com/Brasil/noticia/2017/11/no-brasil-92-dos-lares-temcelular-mas-apenas-66-tem-esgoto-tratado.html. Acesso em 15 de fevereiro de 2020.

ALBERTINI, Jean Mathieu. "Belle, reservée et femme au foyer": les brésiliennes se rebellent contre le facisme. Rue 89. Jet Lag. 03 de maio de 2016. Disponível em: https://www.nouvelobs.com/rue89/rue89-jetlag/20160503.RUE2810/belle-reservee-etfemme-au-foyer-les-bresiliennes-se-rebellent-contre-le-machisme.html. Acesso em 05 de março de 2020.

APÓS reprovação recorde, Temer encerra governo com rejeição em queda, mostra Datafolha . Folha de S. Paulo. 27 de dezembro de 2018. Disponível em: https://www1.folha.uol.com.br/poder/2018/12/apos-reprovacao-recorde-temer-encerragoverno-com-rejeicao-em-queda.shtml Acesso em 05 de março de 2020.

BOLSONARO é acusado de racismo por frase em palestra na Hebraica. Veja. 06 de abril de 2017. Política. Disponível em: https://veja.abril.com.br/brasil/bolsonaro-e-acusadode-racismo-por-frase-em-palestra-na-hebraica/. Acesso em 15 de março de 2020.

BOLSONARO pediu o fuzilamento de Fernando Henrique Cardoso. Vídeo publicado no canal João Iuri de Oliveira no YouTube. 06 de maio de 2013. Disponível em: https://www.youtube.com/watch?v=tOCuftuLhUc. Acesso em 15 de março de 2020.

BOND, Letycia. Alesp aprova projeto que fixa multa para divulgação de notícias falsas. Agência Brasil. Política. 12 de março de 2010. Disponível em: https://agenciabrasil.ebc.com.br/politica/noticia/2020-03/alesp-aprova-projeto-que-fixamulta-para-divulgacao-de-noticias-falsas. Acesso em 29 de março de2020.

CIRO discute com Bolsonaro como retirar a população do SPC. Vídeo do canal Band Jornalismo no YouTube. 09 de agosto de 2018. Disponível em: https://www.youtube.com/watch?v=S-1-VtJ41Ko. Acesso em 19 de janeiro de 2020.

FRANCO, Daniella. Site francês elogia mobilização feminista das brasileiras na internet. RFI. Brasil 03 de maio de 2016. Disponível em: http://www.rfi.fr/br/brasil/20160503site-frances-elogia-mobilizacao-feminista-das-brasileiras-na-internet. Acesso em 5 de março de 2020.

FRASES de Bolsonaro, o candidato que despreza as minorias. IstoÉ. 24 de setembro de 2018. Disponível em: https://istoe.com.br/frases-de-bolsonaro-o-candidato-quedespreza-as-minorias/. Acesso em 20 de março de 2020.

IMPEACHMENT é o melhor caminho. Estadão. Opinião. 07 de abril. Disponível em: https://opiniao.estadao.com.br/noticias/geral,impeachment-e-o-melhorcaminho,10000025268. Acesso em 01 de março de 2020. 
JING, Yi Tsai. Os Memes como recurso de campanha negativa apócrifa na politica. \#MUSEUdeMEMES. Disponível em: https://www.museudememes.com.br/os-memescomo-campanha-negativa-apocrifa-na-politica/. Acesso em 15 de fevereiro de 2020.

LAVADO, Thiago. Uso da internet no Brasil cresce, 70\% da população está conectada. G1. Economia. 28 de agosto de 2019. Disponível em: https:/g1.globo.com/economia/tecnologia/noticia/2019/08/28/uso-da-internet-no-brasilcresce-e-70percent-da-populacao-esta-conectada.ghtml. Acesso em 08 de dezembro de 2019.

LINHARES, Juliana. Marcela Temer: bela, recatada e do lar. Veja. Brasil. 18 de abril de 2016. Disponível em: https://veja.abril.com.br/brasil/marcela-temer-bela-recatada-e-dolar/ Acesso em 1 de março de 2020.

MARTín, María. Deus derruba a presidenta do Brasil. El País Brasil. 19 de abril de 2016. Disponível

em: https://brasil.elpais.com/brasil/2016/04/18/politica/1460935957 433496.html Acesso em 29 de fevereiro de 2020.

MELLO, Patrícia Campos. WhatsApp admite envio massivo ilegal de mensagens nas eleições de 2018. Folha de S.Paulo. Caderno Poder. 8 de outubro de 2018. Disponível em: https://www1.folha.uol.com.br/poder/2019/10/whatsapp-admite-envio-massivoilegal-de-mensagens-nas-eleicoes-de-2018.shtml. Acesso em 08 de dezembro de 2019.

MELO, Debora. A proposta de Ciro Gomes para limpar o nome dos brasileiros no SPC é viável? HuffPost Brasil. 15 de agosto de 2018. Disponível em: https://www.huffpostbrasil.com/entry/a-proposta-de-ciro-gomes-para-limpar-o-nomedos-brasileiros-no-spc-e-viavel br_5c33872fe4b0f65f9273ae98. Acesso em 19 de janeiro de 2020.

MELO, Debora. Horário eleitoral: TSE divulga tempo de TV dos candidatos à Presidência. HuffPost News Brasil. Política. 23 de agosto de 2018. Disponível em: https://www.huffpostbrasil.com/2018/08/23/horario-eleitoral-tse-divulga-tempo-de-tvdos-candidatos-a-presidencia a 23508078/. Acesso em 08 de dezembro de 2019.

MORAES, Camila. A fúria cômica das redes contra o "bela, recatada e dor lar". Eı País Brasil. 22 de abril de 2020. Disponível em: https://brasil.elpais.com/brasil/2016/04/20/politica/1461175399 885009.html. Acesso em 05 de março de 2020.

PEDALADA Fiscal. Senado Notícias. Disponível em: https://www12.senado.leg.br/noticias/entenda-o-assunto/pedalada-fiscal. Acesso em 01 de março de 2020.

PARDELLAS, Sérgio; BARGAMASCO, Débora. Uma presidente fora de si. Istoé. Brasil. 01 de abril de 2016. Disponível em: https://istoe.com.br/450027_UMA+PRESIDENTE+FORA+DE+SI/ Acesso em 01 de março de 2020. 
PENTEADO, Lolo. O look de Marcela Temer na possa de Dilma. Extra. 08 de janeiro de 2011. Disponível em: https://extra.globo.com/famosos/lolo-penteado/o-look-demarcela-temer-na-posse-de-dilma-818439.html Acesso em 01 de março de 2020.

PRESIDÊNCIA da República faz alerta a sites que criam memes com fotos de Temer. G1. Tecnologia. 24 de maio de 2017. Disponível em: https://g1.globo.com/tecnologia/noticia/presidencia-da-republica-faz-alerta-a-sites-quecriam-memes-com-fotos-de-temer.ghtml. Acesso em 24 de julho de 2019.

QUÉRCIA é multado por pichação no Rio. Folha de S. Paulo. Brasil. 02 de fevereiro de 1994. Disponível em: https://www1.folha.uol.com.br/fsp/1994/2/02/brasil/17.html. Acesso em 10 de dezembro de 2019.

SAINT-CLAIR, Clóvis. O discurso e a exacerbação. Época. 25 de outubro de 2018. Disponível em: https://epoca.globo.com/o-discurso-a-exacerbacao-23182202. Acesso em 19 de fevereiro de 2020.

SCHWARTSMAN, Hélio. Guerra contra o humor. Folha de S. Paulo. Opinião. 28 de abril de 2018. Disponível em: https://www1.folha.uol.com.br/colunas/helioschwartsman/2018/04/guerra-contra-ohumor.shtml. Acesso em 25 de julho de 2019.

STANCE. In: Cambridge Dictionary. Cambridge University Press. Disponível em: https://dictionary.cambridge.org/pt/dicionario/ingles/stance. Acesso em 6 de agosto de 2019.

TAVARES, Flávia. Os memes da crise política. Época. Tempo. 11 de maio de 2016. Disponível em: https://epoca.globo.com/tempo/noticia/2016/05/os-memes-da-crisepolitica.html acesso em 03 de outubro de 2019.

TENENTE, Luiza; FIGUEIREDO, Patrícia. Entenda o corte de verba das universidades federais e saiba como são os orçamentos das 10 maiores. G1. Educação. 15 de maio de 2019. Disponível em: https://g1.globo.com/educacao/noticia/2019/05/15/entenda-ocorte-de-verba-das-universidades-federais-e-saiba-como-sao-os-orcamentos-das-10maiores.ghtml. Acesso em 25 de março de 2020.

VEJA a biografia de Jair Bolsonaro, presidente eleito do Brasil. Folha de S. Paulo. 28 de outubro de 2018. Disponível em: https://www1.folha.uol.com.br/poder/2018/10/vejaa-biografia-de-jair-bolsonaro-presidente-eleito-do-brasil.shtml. Acesso em 15 de março de 2020 .

WATERSON, Jim. Unconvered reality of how smartphones turned elections into chaos. The Guardian. UK Politics. Disponível em: https://www.theguardian.com/politics/2019/dec/05/uncovered-reality-of-howsmartphones-turned-election-news-into-chaos. Acesso em 08 de dezembro de 2019.

WOLF, Giovana. Brasil tem 230 milhões de smartphones em uso. UOL. Economia. 04 de abril de 2019. Disponível em: https://economia.uol.com.br/noticias/estadaoconteudo/2019/04/26/brasil-tem-230-mi-de-smartphones-em-uso.htm. Acesso em 15 de fevereiro de 2020. 


\begin{abstract}
ANEXOS
Anexo A - Matéria "Marcela Temer: bela, recatada e do lar"

"Marcela Temer é uma mulher de sorte. Michel Temer, seu marido há treze anos, continua a lhe dar provas de que a paixão não arrefeceu com o tempo nem com a convulsão política que vive o país - e em cujo epicentro ele mesmo se encontra. Há cerca de oito meses, por exemplo, o vicepresidente, de 75 anos, levou Marcela, de 32, para jantar na sala especial do sofisticado, caro e badalado restaurante Antiquarius, em São Paulo. Blindada nas paredes, no teto e no chão para ser à prova de som e garantir os segredos dos muitos políticos que costumam reunir-se no local, a sala tem capacidade para acomodar trinta pessoas, mas foi esvaziada para receber apenas "Mar" e "Mi", como são chamados em família. Lá, protegido por quatro seguranças (um na cozinha, um no toalete, um na entrada da sala e outro no salão principal do restaurante), o casal desfrutou algumas horas de jantar romântico sob um céu estrelado, graças ao teto retrátil do ambiente. Marcela se casou com Temer quando tinha 20 anos. O vice, então com 62, estava no quinto mandato como deputado federal e foi seu primeiro namorado.
\end{abstract}

Michelzinho, de 7 anos, cabelo tigelinha e uma bela janela no lugar que abrigará seus incisivos centrais, é o único filho do casal (Temer tem outros quatro de relacionamentos anteriores). No fim do ano passado, Marcela pensou que esperava o segundo filho, mas foi um alarme falso. "No final, eles acharam que não teria sido mesmo um bom momento para ela engravidar, dada a confusão no país", conta tia Nina, irmã da mãe de Marcela. Ela se refez do sobressalto, mas não se resignou - ainda quer ter uma menininha. No Carnaval, Marcela planejou uns dias de sol e praia só com o marido e o filho e foi para a Riviera de São Lourenço, no Litoral Norte de São Paulo. Temer iria depois, mas, nos dias seguintes, o plano foi a pique: o vice ligou, dizendo que estava receoso de expor a família, devido aos ânimos acirrados no país. Pegou Marcela, Michelzinho, e todo mundo voltou para casa.

Bacharel em direito sem nunca ter exercido a profissão, Marcela comporta em seu curriculum vitae um curto período de trabalho como recepcionista e dois concursos de miss no interior de São Paulo (representando Campinas e Paulínia, esta sua cidade natal). Em ambos, ficou em segundo lugar. Marcela é uma vice-primeira-dama do lar. Seus dias consistem em levar e trazer Michelzinho da escola, cuidar da casa, em São Paulo, e um pouco dela mesma também (nas últimas três semanas, foi duas vezes à dermatologista tratar da pele).

Por algum tempo, frequentou o salão de beleza do cabeleireiro Marco Antonio de Biaggi, famoso pela clientela estrelada. Pedia luzes bem fininhas e era "educadíssima", lembra o cabeleireiro. "Assim como faz a Athina Onassis quando vem ao meu salão, ela deixava os seguranças do lado de fora", informa Biaggi. Na opinião do cabeleireiro, Marcela "tem tudo para se tornar a nossa Grace Kelly". Para isso, falta só "deixar o cabelo preso". Em todos esses anos de atuação política do marido, ela apareceu em público pouquíssimas vezes. "Marcela sempre chamou atenção pela beleza, mas sempre foi recatada", diz sua irmã mais nova, Fernanda Tedeschi. "Ela gosta de vestidos até os joelhos e cores claras", conta a estilista Martha Medeiros.

Marcela é o braço digital do vice. Está constantemente de olho nas redes sociais e mantém o marido informado sobre a temperatura ambiente. Um fica longe do outro a maior parte da semana, uma vez que Temer mora de segunda a quinta-feira no Palácio do Jaburu, em Brasília, e Marcela permanece em São Paulo, quase sempre na companhia da mãe. Sacudida, loiríssima e de olhos azuis, Norma Tedeschi acompanhou a filha adolescente em seu primeiro encontro com Temer. Amigos do vice contam que, ao fim de um dia extenuante de trabalho, é comum vê-lo tomar um vinho, fumar um charuto e 'mergulhar num outro mundo' - o que ocorre, por exemplo, quando 
telefona para Marcela ou assiste a vídeos de Michelzinho, que ela manda pelo celular. Três anos atrás, Temer lançou o livro de poemas intitulado Anônima Intimidade. Um deles, na página 135, diz: 'De vermelho / Flamejante / Labaredas de fogo / Olhos brilhantes / Que sorriem / Com lábios rubros / Incêndios / Tomam conta de mim / Minha mente / Minha alma / Tudo meu / Em brasas / Meu corpo / Incendiado / Consumido / Dissolvido / Finalmente / Restam cinzas / Que espalho na cama / Para dormir'.

Michel Temer é um homem de sorte."

(LINHARES, Juliana. Marcela Temer: Bela, recatada e do lar. Veja, Brasil, edição 2474 - publicada em 21 de abril de 2016, p. 28-29)

Anexo B - Meme "Bela, recatada e do bar"

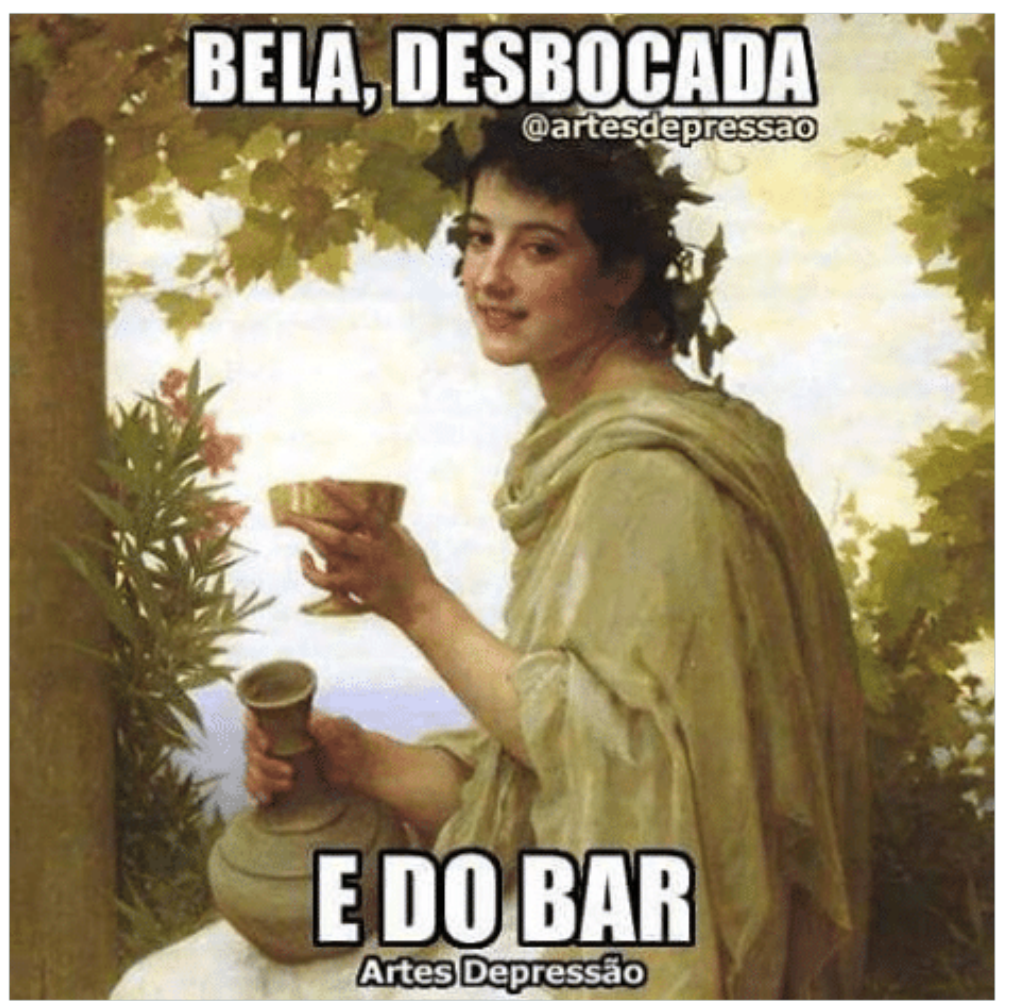

Fonte:

https:/www.researchgate.net/publication/322359530/figure/fig2/AS:611897770524677@,152289920534 1/Figura-2-Meme-a-partir-de-bela-recatada-e-do-lar.png. Acesso em 06 de abril de 2020. 
Anexo C - Meme "Bela, recatada e dólar"

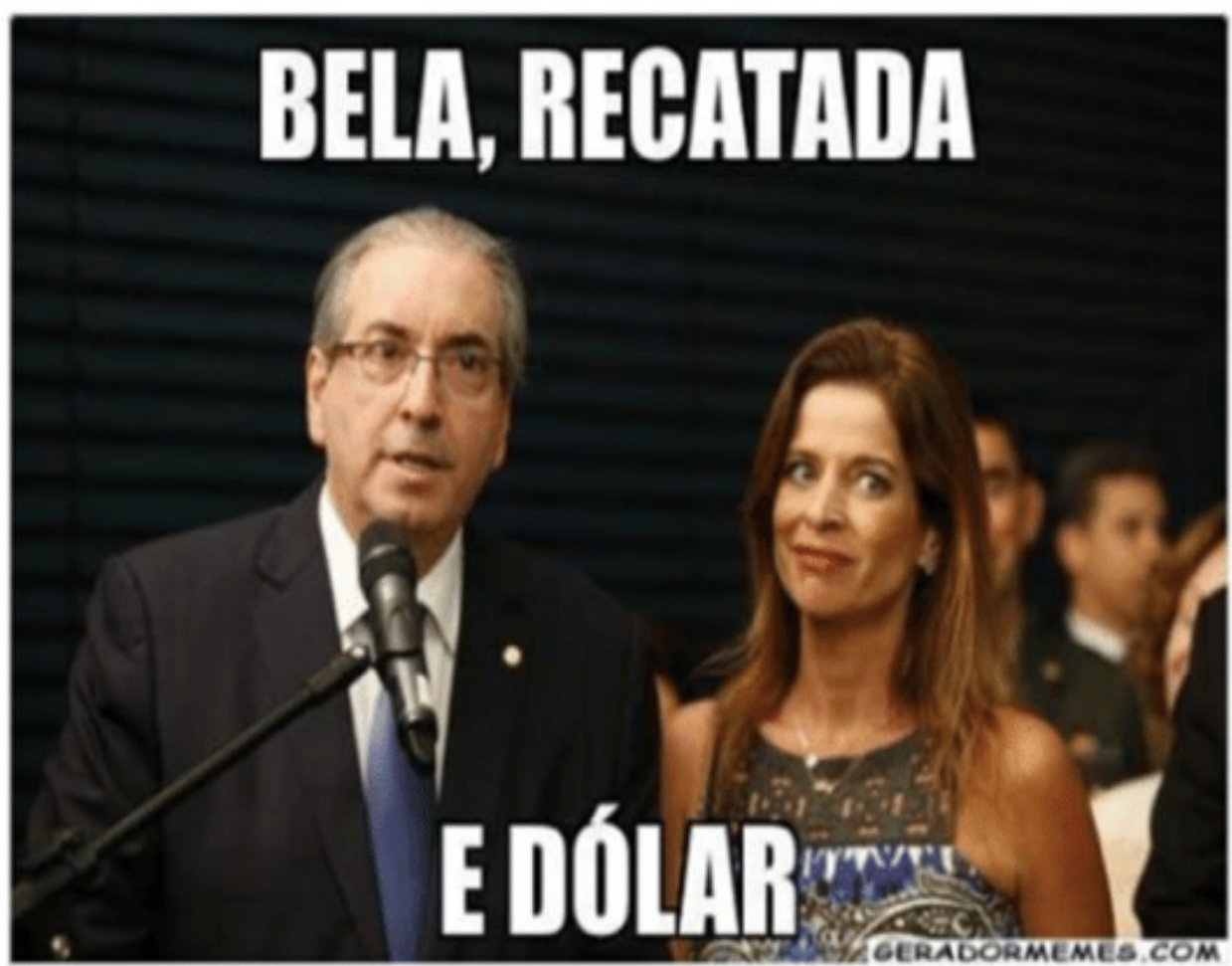

Fonte:

https:/www.researchgate.net/publication/322359530/figure/fig3/AS:611897770508289@152289920537 8/Figura-3-Meme-a-partir-de-bela-recatada-e-do-lar.png. Acesso em 06 de abril de 2020.

Anexo D - Meme "Vamos jantar fora, Temer?"

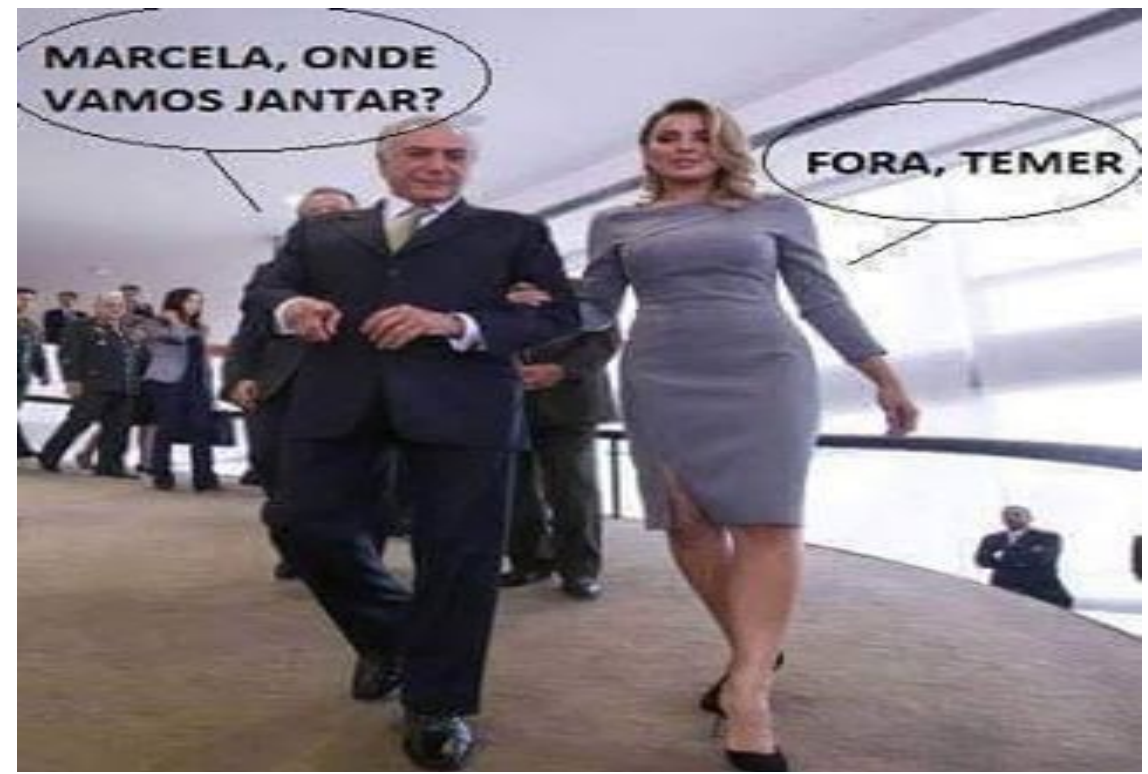

Fonte: https://br.pinterest.com/pin/735775657841460042/. Acesso em 27 de março de 2020 
Anexo E - Meme "Primeiramente, fora eu"

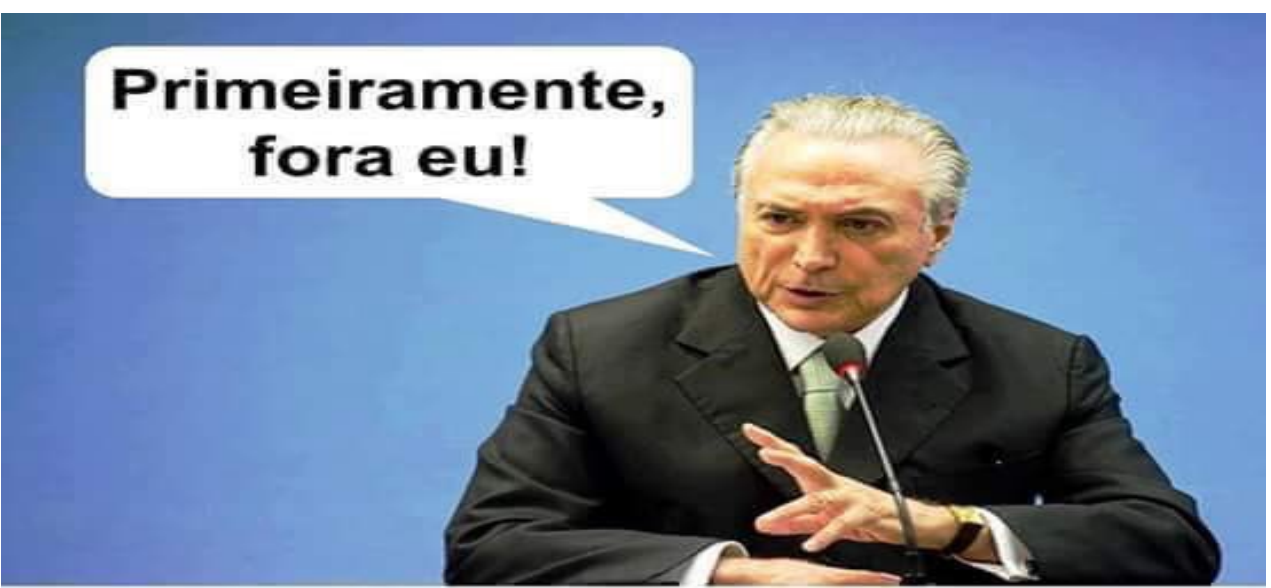

Fonte: https://pbs.twimg.com/media/CpIdy20WYAELPPS?format=ipg\&name=small . Acesso em 27 de março de 2020.

Anexo F - Meme "Tive que perder para aprender"

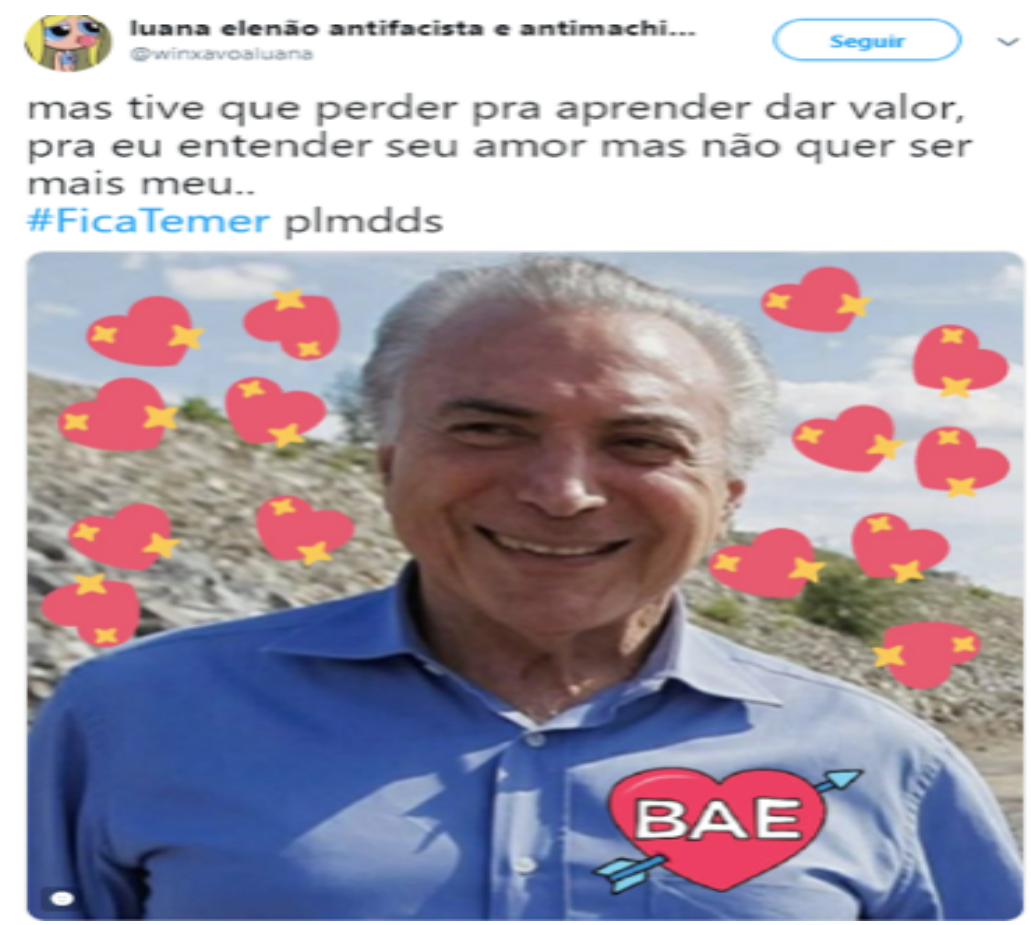

Fonte: http://www.museudememes.com.br/sermons/ficatemer/. Acesso em 27 de março de 2020. 
Anexo G - Meme "Fora Temer? Jamais!"

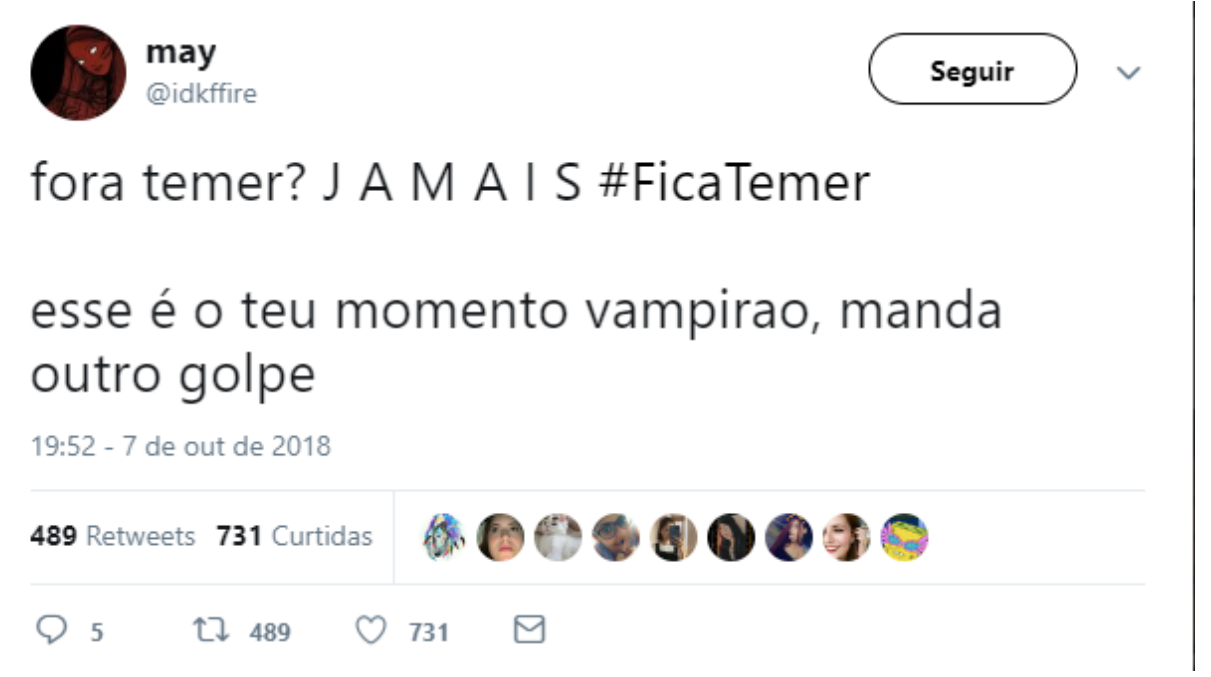

Fonte: http://www.museudememes.com.br/sermons/ficatemer/. Acesso em 27 de março de 2020. 